In cooperation with the U.S. Bureau of Reclamation

\title{
Documentation of a Groundwater Flow Model (SJRRPGW) for the San Joaquin River Restoration Program Study Area, California
}

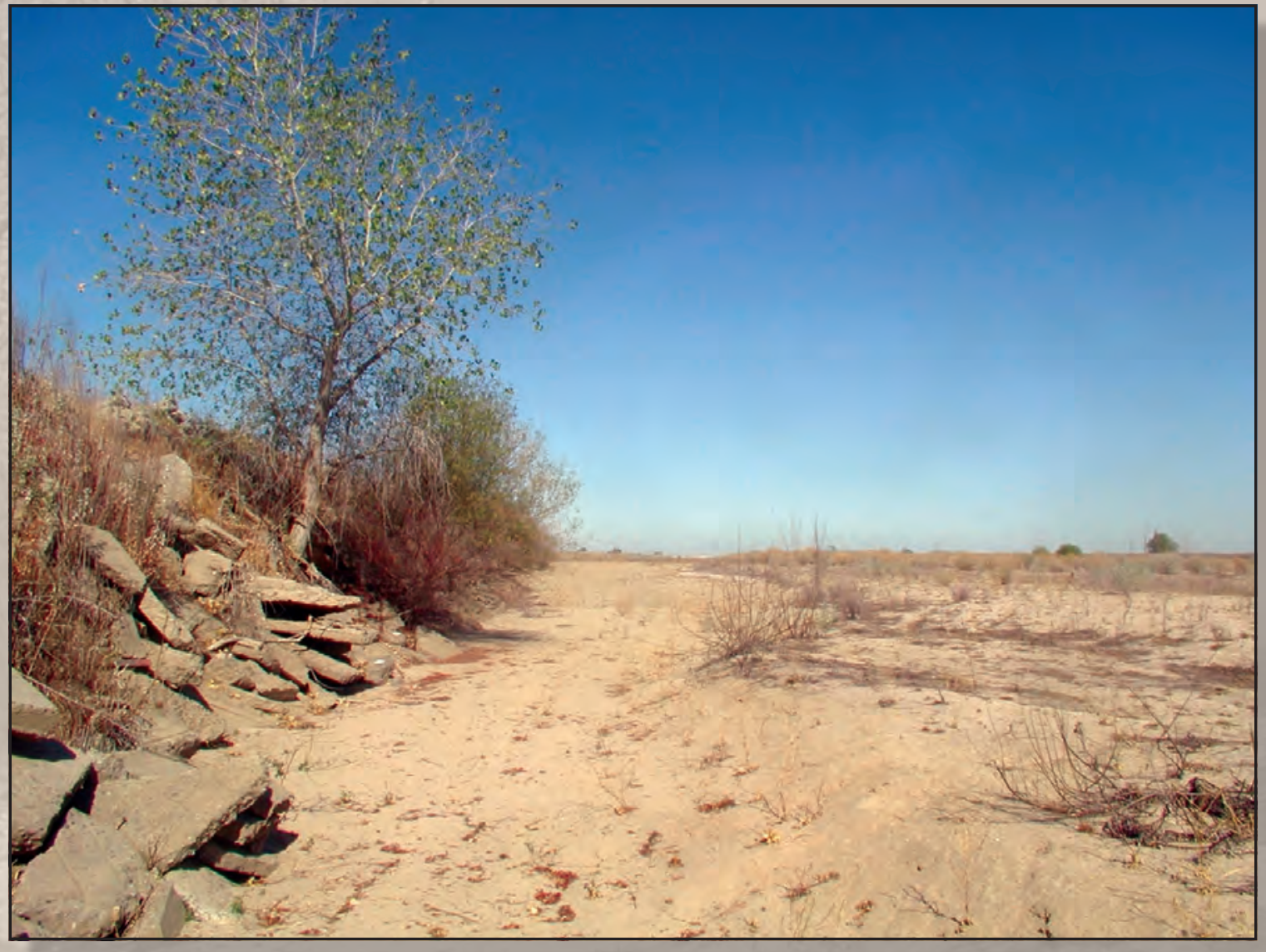

Scientific Investigations Report 2014-5148 
Cover photo: Picture taken of San Joaquin River Reach 2A (river mile 219) looking downstream in July 2009. Photo taken by Doug Deflitch, U.S. Bureau of Reclamation. 


\section{Documentation of a Groundwater Flow Model (SJRRPGW) for the San Joaquin River Restoration Program Study Area, California}

By Jonathan A. Traum, Steven P. Phillips, George L. Bennett, Celia Zamora, and Loren F. Metzger

In cooperation with the U.S. Bureau of Reclamation

Scientific Investigations Report 2014-5148 


\title{
U.S. Department of the Interior SALLY JEWELL, Secretary
}

\section{U.S. Geological Survey Suzette M. Kimball, Acting Director}

\author{
U.S. Geological Survey, Reston, Virginia: 2014
}

For more information on the USGS - the Federal source for science about the Earth, its natural and living resources, natural hazards, and the environment, visit http://www.usgs.gov or call 1-888-ASK-USGS.

For an overview of USGS information products, including maps, imagery, and publications, visit http://www.usgs.gov/pubprod

To order this and other USGS information products, visit http://store.usgs.gov

Any use of trade, firm, or product names is for descriptive purposes only and does not imply endorsement by the U.S. Government.

Although this information product, for the most part, is in the public domain, it also may contain copyrighted materials as noted in the text. Permission to reproduce copyrighted items must be secured from the copyright owner.

Suggested citation:

Traum, J.A., Phillips, S.P., Bennett, G.L., Zamora, Celia, and Metzger, L.F., 2014, Documentation of a groundwater flow model (SJRRPGW) for the San Joaquin River Restoration Program study area, California: U.S. Geological Survey Scientific Investigations Report 2014-5148, 151 p., http://dx.doi.org/10.3133/sir20145148. 


\section{Conversion Factors}

Inch/Pound to SI

\begin{tabular}{|c|c|c|}
\hline Multiply & By & To obtain \\
\hline \multicolumn{3}{|c|}{ Length } \\
\hline inch (in) & 2.54 & centimeter $(\mathrm{cm})$ \\
\hline foot $(\mathrm{ft})$ & 0.3048 & meter $(\mathrm{m})$ \\
\hline mile (mi) & 1.609 & kilometer (km) \\
\hline \multicolumn{3}{|c|}{ Area } \\
\hline acre & 4,047 & square meter $\left(\mathrm{m}^{2}\right)$ \\
\hline square mile $\left(\mathrm{mi}^{2}\right)$ & 2.590 & square kilometer $\left(\mathrm{km}^{2}\right)$ \\
\hline \multicolumn{3}{|c|}{ Volume } \\
\hline acre-foot (acre-ft) & 1,233 & cubic meter $\left(\mathrm{m}^{3}\right)$ \\
\hline \multicolumn{3}{|c|}{ Flow rate } \\
\hline acre-foot per month (acre-ft/month) & 0.0004691 & cubic meter per second $\left(\mathrm{m}^{3} / \mathrm{s}\right)$ \\
\hline acre-foot per year (acre-ft/yr) & 0.00003909 & cubic meter per second $\left(\mathrm{m}^{3} / \mathrm{s}\right)$ \\
\hline cubic foot per second $\left(\mathrm{ft}^{3} / \mathrm{s}\right)$ & 0.02832 & cubic meter per second $\left(\mathrm{m}^{3} / \mathrm{s}\right)$ \\
\hline \multicolumn{3}{|c|}{ Hydraulic conductivity } \\
\hline foot per day (ft/d) & 0.3048 & meter per day $(\mathrm{m} / \mathrm{d})$ \\
\hline \multicolumn{3}{|c|}{ Hydraulic conductance } \\
\hline foot squared per day $\left(\mathrm{ft}^{2} / \mathrm{d}\right)$ & 0.09290 & meter squared per day $\left(\mathrm{m}^{2} / \mathrm{d}\right)$ \\
\hline
\end{tabular}

Temperature in degrees Celsius $\left({ }^{\circ} \mathrm{C}\right)$ may be converted to degrees Fahrenheit $\left({ }^{\circ} \mathrm{F}\right)$ as follows:

${ }^{\circ} \mathrm{F}=\left(1.8 x^{\circ} \mathrm{C}\right)+32$

Temperature in degrees Fahrenheit $\left({ }^{\circ} \mathrm{F}\right)$ may be converted to degrees Celsius $\left({ }^{\circ} \mathrm{C}\right)$ as follows:

${ }^{\circ} \mathrm{C}=\left({ }^{\circ} \mathrm{F}-32\right) / 1.8$

Vertical coordinate information is referenced to North American Vertical Datum of 1988

(NAVD 88). Elevation, as used in this report, refers to distance above the vertical datum.

Horizontal coordinate information is referenced to the North American Datum 1983 (NAD 83) geographic coordinate system. The projected coordinate system used is State Plane California Zone III in ft. 


\section{Abbreviations}

$\begin{array}{ll}\text { CCID } & \text { Central California Irrigation District } \\ \text { CVHM } & \text { Central Valley Hydrologic Model } \\ \text { CVP } & \text { Central Valley Project } \\ \text { DAU } & \text { Detailed Analysis Unit } \\ \text { DTW } & \text { depth to the water table } \\ \text { DWR } & \text { California Department of Water Resources } \\ \text { ET } & \text { actual evapotranspiration } \\ \text { ET } & \text { reference evapotranspiration } \\ \text { Fei } & \text { fraction of evaporation of irrigation } \\ \text { Fep } & \text { fraction of evaporation of precipitation } \\ \text { FMP2 } & \text { Farm Process } \\ \text { Ftr } & \text { fraction of transpiration } \\ \text { GIRAS } & \text { Geographic Information Retrieval and Analysis System } \\ \text { HEC-RAS } & \text { Hydrologic Engineering Centers River Analysis System } \\ \text { HUF } & \text { Hydrogeologic Unit Flow } \\ \text { IDW } & \text { inverse distance weighting } \\ \text { MPG } & \text { Mendota Pool Group } \\ \text { NHD } & \text { National Hydrography Dataset } \\ \text { NLCD } & \text { North American Land Class Data } \\ \text { NWIS } & \text { National Water Information System } \\ \text { PAs } & \text { Planning Areas } \\ \text { PEST } & \text { parameter estimation software } \\ \text { PRISM } & \text { Parameter-Elevation Regressions on Independent Slopes Model } \\ \text { Reclamation } & \text { U.S. Bureau of Reclamation } \\ \text { SJAxial } & \text { San Joaquin Axial } \\ \text { SJDist } & \text { San Joaquin Distal } \\ \text { SJProx } & \text { San Joaquin Proximal } \\ \text { SJRRP } & \text { San Joaquin River Restoration Program } \\ \text { SJRRPGW } & \text { San Joaquin River Restoration Program groundwater flow model } \\ \text { SFR2 } & \text { Streamflow-Routing Package } \\ \text { TPROGS } & \text { Transition-Probability Geostatistical Software } \\ \text { USGS } & \text { Westside Fans } \\ \text { WSFans } & \end{array}$




\section{Acknowledgments}

Many people contributed to the successful development of the San Joaquin River Restoration Program groundwater flow model (SJRRPGW). Claudia Faunt (U.S. Geological Survey) provided valuable technical expertise on model development and also provided data from the Central Valley Hydrologic Model (CVHM) that were used to develop several SJRRPGW input files. Randy Hanson (U.S. Geologicl Survey) and Wolfgang Schmid (University of Arizona), developers of the Farm Process (FMP2) for MODFLOW, provided assistance implementing MODFLOW-FMP2 for the SJRRPGW. John Doherty (Watermark Numerical Computing) developed the BeoPEST software used for SJRRPGW calibration, provided technical support on using BeoPEST, and added features to BeoPEST to support this work. Susan Cundiff (Tetra Tech) developed the stream rating tables used in the SJRRPGW. Steven Predmore (U.S. Geological Survey) and Donald Martin (U.S. Geological Survey) developed custom tools and scripts for pre- and post-processing model datasets. Katrina Harrison (U.S. Bureau of Reclamation), Chris White (Central California Irrigation District), and Chris Montoya (California Department of Water Resources) provided valuable unpublished data used to develop the model. The San Joaquin River Restoration Program (SJRRP) seepage subgroup, which includes staff from Reclamation, staff from California Department of Water Resources (DWR), and Brian Heywood (CDM Smith), provided guidance on the model development. 


\section{Contents}

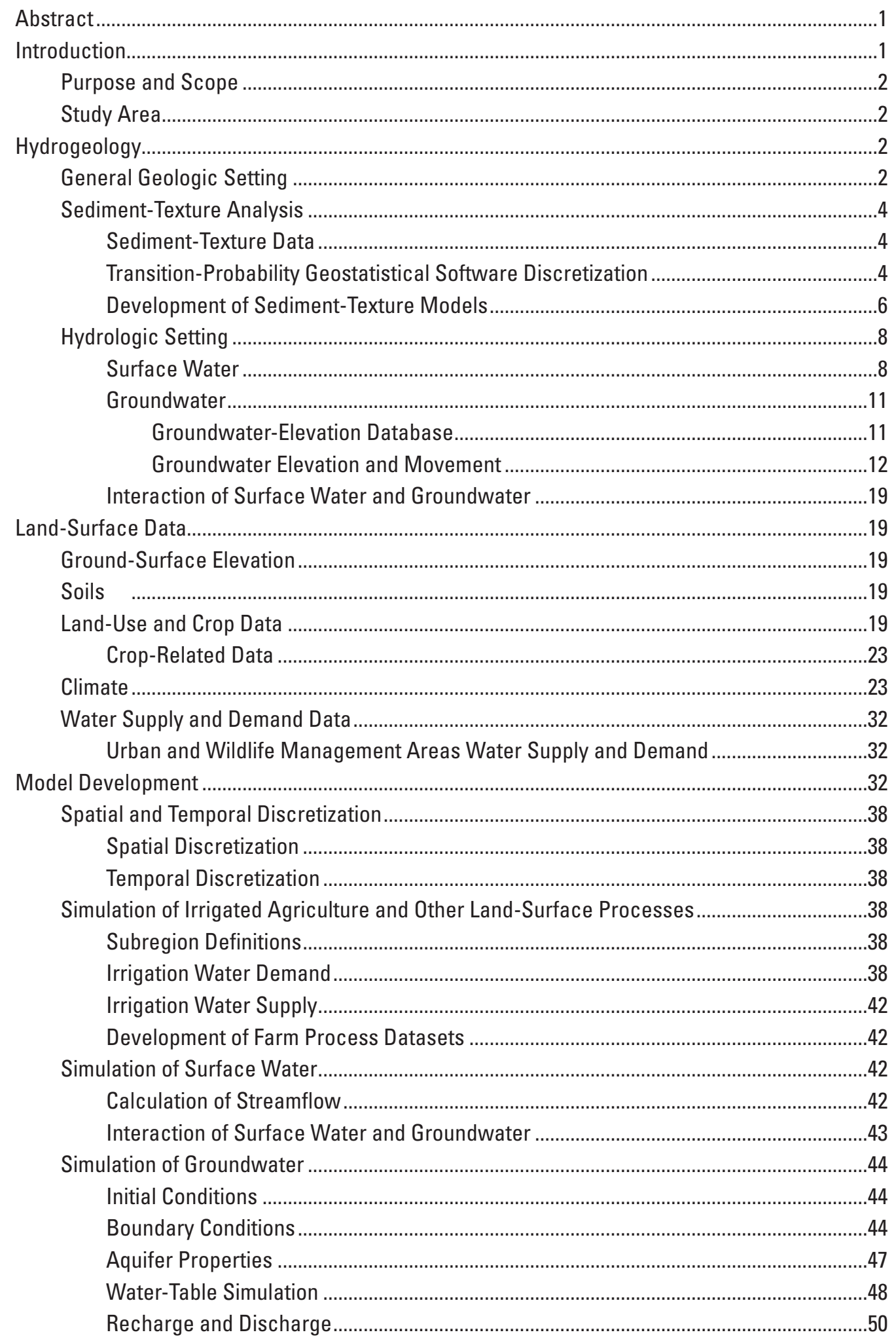




\section{Contents-Continued}

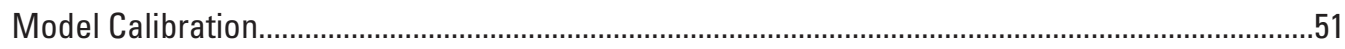

Calibration Data.

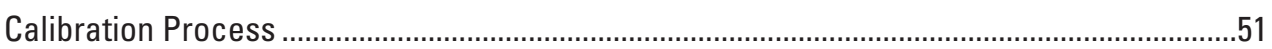

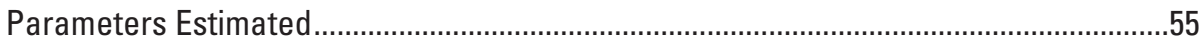

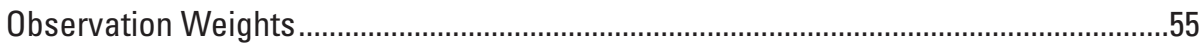

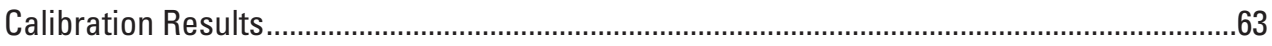

Model Fit to Observations of Groundwater Elevations ...............................................63

Groundwater Elevations at Representative Calibration Wells.................................66

Model Fit to Streamflow Observations...........................................................................72

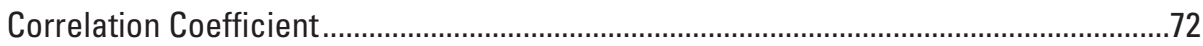

Sensitivity Analysis and Parameter Uncertainty ................................................................

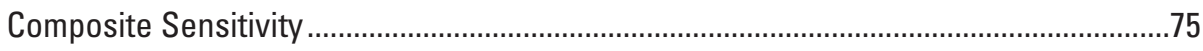

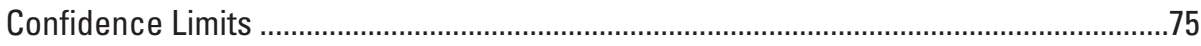

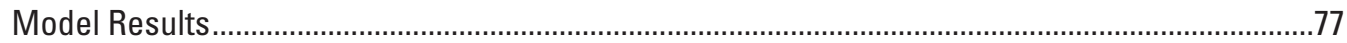

Simulated Hydrologic Budgets .......................................................................................

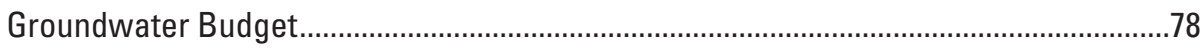

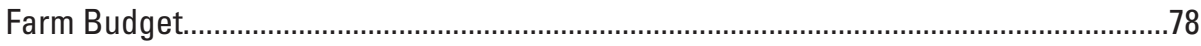

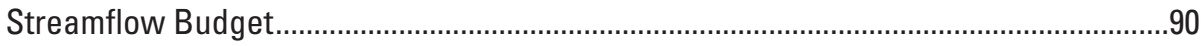

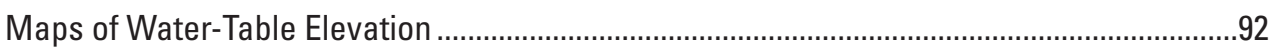

Maps of Groundwater and Surface-Water Interaction.........................................................99

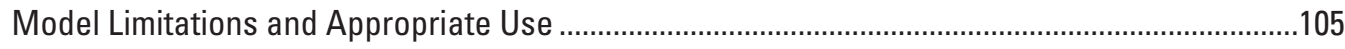

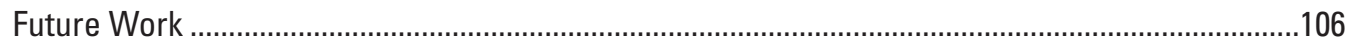

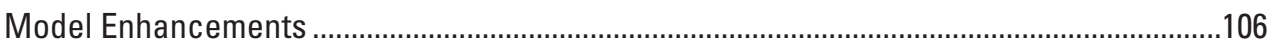

Investigate Predictive Uncertainty of Simulated Stream Seepage......................................106

Sensitivity to Transition-Probability Geostatistical Software Texture Realizations......106

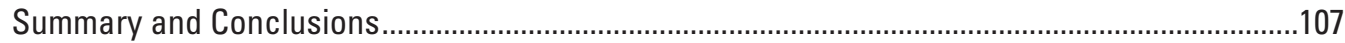

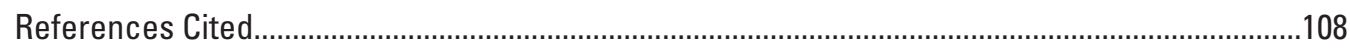

Appendix A. Crop-Related Data Utilized from the Central Valley Hydrologic Model..................111

Appendix B. Information for San Joaquin River Restoration Program Groundwater Model

Calibration Wells ..........................................................................................................119

Appendix C. Calibration Results...........................................................................................127 


\section{Figures}

1. Map showing study area, San Joaquin Valley, California

2. Map showing grid extent, geologic domains, and locations of wells used for the Transition-Probability Geostatistical Software model, San Joaquin Valley, California

3. Graphs showing the relation between vertical transition probabilities for each facies and geologic domain measured from borehole data and simulated using Markov chain models, San Joaquin Valley study area, California

4. Diagram showing combined model of sediment-texture distribution derived from Transition-Probability Geostatistical Software of four geologic domains in the San Joaquin Valley, California .

5. Map showing streamflow network in the study area, San Joaquin Valley, California

6. Graph showing monthly average stream inflow and outflow to study area, San Joaquin Valley, California

7. Graphs showing semi-variogram results corresponding to the kriged depth to water-table maps, San Joaquin Valley, California: $A, 1981 ; B, 1983 ; C, 1988$; $D, 1991$; and $E, 2006$.

8. Maps showing interpolated depth to water table in study area, San Joaquin Valley, California: $A$, Fall 1981, a Normal-Dry water year; $B$, Fall 1983, a Wet water year; C, Fall 1988, a Dry water year; D, Fall 1991, a Normal-Dry water year; $E$, Fall 2006, a Wet water year.

9. Map showing ground-surface elevation in the study area, San Joaquin Valley, California

10. Map showing soil classifications in the study area, San Joaquin Valley, California

11. Maps showing distribution of crop type in the study area, San Joaquin Valley, California: A, 1961-68; B, 1968-78; C, 1978-93; D, 1994-99; E, 1999-2003

12. Map showing annual average precipitation in the study area, San Joaquin Valley, California

13. Graph showing monthly average precipitation and evapotranspiration in the study area, San Joaquin Valley, California.

14. Map showing annual average evapotranspiration in the study area, San Joaquin Valley, California 31

15. Graph showing annual surface-water deliveries to the study area, San Joaquin Valley, California

16. Graph showing monthly average surface deliveries to the study area, San Joaquin Valley, California

17. Map showing estimated spatial distribution of urban groundwater pumping in the study area for April 1999-September 2003, San Joaquin Valley, California.

18. Graphs showing estimated urban groundwater pumping in the study area, San Joaquin Valley, California: $A$, Annual; $B$, Monthly

19. Map showing wildlife management areas simulated in the study area, San Joaquin Valley, California

20. Map showing San Joaquin River Restoration Program groundwater flow model grid, San Joaquin Valley, California

21. Map showing San Joaquin River Restoration Program groundwater flow model subregions, San Joaquin Valley, California 


\section{Figures-Continued}

22. Graph showing streambed elevation along Chowchilla Bypass, San Joaquin Valley, California

23. Map showing San Joaquin River Restoration Program groundwater flow model initial groundwater elevation, San Joaquin Valley, California

24. Map showing San Joaquin River Restoration Program groundwater flow model division of general-head model boundaries, San Joaquin Valley, California

25. Diagrams showing an example of horizontal combination of Transition-Probability Geostatistical Software grid cells onto the San Joaquin River Restoration Program groundwater flow model grid cells, San Joaquin Valley, California

26. Diagrams showing an example Hydrogeologic Unit Flow Package combination of vertical Transition-Probability Geostatistical Software texture layers onto the San Joaquin River Restoration Program groundwater flow model layers, San Joaquin Valley, California

27. Map showing San Joaquin River Restoration Program groundwater flow model uppermost active layer for each model cell, San Joaquin Valley, California

28. Map showing observation wells used in the San Joaquin River Restoration Program groundwater flow model calibration, San Joaquin Valley, California

29. Map showing location of streamgages used in the San Joaquin River Restoration Program groundwater flow model calibration, San Joaquin Valley, California

30. Graphs showing relation between simulated and observed groundwater elevations: $A$, Histogram of residual groundwater elevations; $B$, Simulated and observed groundwater elevations; $C$, Residual and observed groundwater elevations.

31. Map showing average residual (simulated - observed) groundwater elevation at observation wells used in the San Joaquin River Restoration Program groundwater flow model calibration, San Joaquin Valley, California..

32. Representative hydrographs for each San Joaquin River Restoration Program groundwater flow model calibration area comparing simulated and observed groundwater elevations, San Joaquin Valley, California: $A$, Fresno; $B$, Madera Area; $C$, Mendota; $D$, Chowchilla; $E$, Central California Irrigation District (CCID) South - shallow; F, CCID South - deep; $G$, Merced; $H$, CCID North

33. Graphs showing relation between simulated and observed streamflows:

$A$, histogram of residuals between simulated and observed streamflows;

$B$, simulated and observed streamflows; $C$, residual and observed streamflows

34. Graph showing simulated and observed streamflow downstream from

San Joaquin River Reach 5, San Joaquin Valley, California.

35. Graphs showing relative composite sensitivities of San Joaquin River

Restoration Program groundwater flow model parameters, San Joaquin Valley, California: $A$, sensitivity to crop coefficients for each crop type; $B$, sensitivity to irrigation efficiencies for each subregion; $C$, sensitivity to hydraulic parameters..........76

36. Graph showing San Joaquin River Restoration Program groundwater flow model annual groundwater budget and cumulative change in groundwater storage, San Joaquin Valley, California .....

37. Map showing San Joaquin River Restoration Program groundwater flow model agricultural water supply by subregion, San Joaquin Valley, California. 


\section{Figures-Continued}

38. Map showing San Joaquin River Restoration Program groundwater flow model agricultural water demand by subregion, San Joaquin Valley, California. 86

39. Graph showing San Joaquin River Restoration Program groundwater flow model annual average farm budget, San Joaquin Valley, California

40. Graphs showing San Joaquin River Restoration Program groundwater flow model annual seepage for San Joaquin River Management Reaches, San Joaquin Valley, California: $A$, Reach 1; $B$, Reach 2; $C$, Reach 3; $D$, Reach 4; E, Reach 5

41. Maps showing San Joaquin River Restoration Program groundwater flow model-simulated groundwater elevation and depth to water table, San Joaquin Valley, California: $A$, Fall 1981 simulated groundwater elevation; $B$, Fall 1981 simulated depth to water table; $C$, Fall 1983 simulated groundwater elevation; $D$, Fall 1983 simulated depth to water table; $E$, Fall 1988 simulated groundwater elevation; F, Fall 1988 simulated depth to water table; G, Fall 1991 simulated groundwater elevation; $H$, Fall 1991 simulated depth to water table

42. Map showing San Joaquin River Restoration Program groundwater flow model average groundwater and surface-water interaction, San Joaquin Valley, California

A-1. Graph showing monthly crop coefficients for each crop utilized in the San Joaquin River Restoration Program groundwater flow model by different land-use types: $A$, agricultural, undeveloped, and other uses; $B$, agricultural uses; $C$, agricultural and other developed uses

C-1. Hydrographs showing simulated and observed groundwater elevations at each calibration well in the San Joaquin valley, 1961-2001: $A$, calibration wells 1-8; $B$, calibration wells 9-16; $C$, calibration wells $17-24$; $D$, calibration wells $25-32$; E, calibration wells $33-40 ; F$, calibration wells $41-48 ; G$, calibration wells 49-56; $H$, calibration wells 57-64; I, calibration wells 65-72; J, calibration wells 73-80; $K$, calibration wells 81-88; $L$, calibration wells 89-96; $M$, calibration wells 97-104; $N$, calibration wells $105-112 ; 0$, calibration wells 113-120; $P$, calibration wells 121-128; Q, calibration wells 129-133

C-2. Hydrographs showing differences between simulated and observed streamflow at all 19 calibration streamgages in the San Joaquin valley, 1940-2005: $A$, San Joaquin River (SJR) near El Nido, Gravelly Ford, and Chowchilla Bypass at Head above Bifurcation; $B$, SJR below Bifurcation, SJR near Mendota, and SJR near Dos Palos; $C$, Eastside bypass near El Nido, SJR near El Nido, and Eastside Bypass below Mariposa Bypass; D, Bear Creek below Eastside Canal, SJR near Stevinson, and Salt Slough at Highway 165 near Stevinson; E, SJR at Fremont Ford Bridge, Mud Slough near Gustine, and Merced River near Stevinson; F, SJR near Newman, Donney Bridge, and Mariposa Bypass near Crane Ranch; G, SJR near Crows Landing..... 


\section{Tables}

1. Proportions and mean lengths used in the Transition-Probability Geostatistical Software model for each geologic domain in the San Joaquin Valley study area,

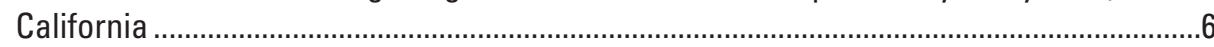

2. Streamflow data available in study area, San Joaquin Valley, California.........................9

3. Minimum, maximum, and mean difference between interpolated and known values of depth to water table for a given year, San Joaquin Valley, California..............12

4. Land-use data available for the study area, San Joaquin Valley, California ....................22

5. Crop types in the study area, San Joaquin Valley, California..........................................22

6. MODFLOW packages and processes used in the San Joaquin River Restoration Program groundwater flow model, San Joaquin Valley, California .................................37

7. San Joaquin River Restoration Program groundwater flow model subregion descriptions, San Joaquin Valley, California.

8. Example distribution of aquifer texture in the San Joaquin River Restoration Program groundwater flow model, San Joaquin Valley, California

9. Percentage of wells screened above the Corcoran Clay, San Joaquin Valley, California....

10. Streamgages used in the San Joaquin River Restoration Program groundwater flow model calibration, San Joaquin Valley, California

11. Prior information used for calibration of the San Joaquin River Restoration Program groundwater flow model model, San Joaquin Valley, California

12. San Joaquin River Restoration Program groundwater flow model final parameter values, San Joaquin Valley, California

13. Comparison of San Joaquin River Restoration Program groundwater flow model parameter values to values in similar studies, San Joaquin Valley, California

14. Components of San Joaquin River Restoration Program groundwater flow model simulated hydrologic budgets, San Joaquin Valley, California.

15. San Joaquin River Restoration Program groundwater flow model annual average groundwater budget by subregion, San Joaquin Valley, California

16. San Joaquin River Restoration Program groundwater flow model annual groundwater budget, San Joaquin Valley, California

17. San Joaquin River Restoration Program groundwater flow model monthly average groundwater budget, San Joaquin Valley, California

18. San Joaquin River Restoration Program groundwater flow model annual average farm budget by subregion, San Joaquin Valley, California

19. San Joaquin River Restoration Program groundwater flow model annual average farm budget, San Joaquin Valley, California

20. San Joaquin River Restoration Program groundwater flow model monthly average farm budget, San Joaquin Valley, California

21. San Joaquin River Restoration Program groundwater flow model annual average streamflow budget, San Joaquin Valley, California

22. San Joaquin River Restoration Program groundwater flow model monthly average streamflow budget, San Joaquin Valley, California 


\section{Tables-Continued}

A-1. Non-time varying crop-related data in study area for each crop type

A-2. Fractions of transportation and evaporation of consumptive use for each crop type

A-3. Irrigation efficiencies through the simulation period averaged by San Joaquin River Restoration Program groundwater flow model subregion, San Joaquin Valley, California

B-1. Well information for selected Central California Irrigation District monitoring wells used in model calibration for the San Joaquin River Restoration Project area, Fresno, Madera, and Merced Counties, California

B-2. Well information for selected wells from the California Department of Water Resources and U.S. Geological Survey databases used in model calibration for the San Joaquin River Restoration Project area, Fresno, Madera, and Merced Counties, California 


\title{
Documentation of a Groundwater Flow Model (SJRRPGW) for the San Joaquin River Restoration Program Study Area, California
}

\author{
By Jonathan A. Traum, Steven P. Phillips, George L. Bennett, Celia Zamora, and Loren F. Metzger
}

\section{Abstract}

To better understand the potential effects of restoration flows on existing drainage problems, anticipated as a result of the San Joaquin River Restoration Program (SJRRP), the U.S. Geological Survey (USGS), in cooperation with the U.S. Bureau of Reclamation (Reclamation), developed a groundwater flow model (SJRRPGW) of the SJRRP study area that is within 5 miles of the San Joaquin River and adjacent bypass system from Friant Dam to the Merced River. The primary goal of the SJRRP is to reestablish the natural ecology of the river to a degree that restores salmon and other fish populations. Increased flows in the river, particularly during the spring salmon run, are a key component of the restoration effort. A potential consequence of these increased river flows is the exacerbation of existing irrigation drainage problems along a section of the river between Mendota and the confluence with the Merced River. Historically, this reach typically was underlain by a water table within 10 feet of the land surface, thus requiring careful irrigation management and (or) artificial drainage to maintain crop health. The SJRRPGW is designed to meet the short-term needs of the SJRRP; future versions of the model may incorporate potential enhancements, several of which are identified in this report.

The SJRRPGW was constructed using the USGS groundwater flow model MODFLOW and was built on the framework of the USGS Central Valley Hydrologic Model (CVHM) within which the SJRRPGW model domain is embedded. The Farm Process (FMP2) was used to simulate the supply and demand components of irrigated agriculture. The Streamflow-Routing Package (SFR2) was used to simulate the streams and bypasses and their interaction with the aquifer system. The 1,300-square mile study area was subdivided into 0.25 -mile by 0.25 -mile cells. The sediment texture of the aquifer system, which was used to distribute hydraulic properties by model cell, was refined from that used in the CVHM to better represent the natural heterogeneity of aquifer-system materials within the model domain. In addition, the stream properties were updated from the CVHM to better simulate stream-aquifer interactions, and waterbudget subregions were refined to better simulate agricultural water supply and demand. External boundary conditions were derived from the CVHM.

The SJRRPGW was calibrated for April 1961 to September 2003 by using groundwater-level observations from 133 wells and streamflow observations from 19 streamgages. The model was calibrated using public-domain parameter estimation software (PEST) in a semi-automated manner. The simulated groundwater-level elevations and trends (including seasonal fluctuations) and surface-water flow magnitudes and trends reasonably matched observed data. The calibrated model is planned to be used to assess the potential effects of restoration flows on agricultural lands and the relative capabilities of proposed SJRRP actions to reduce these effects.

\section{Introduction}

More than a century of human development in the San Joaquin Valley has led to a decline in the quantity and diversity of aquatic and riparian habitats along the lower San Joaquin River. The building of Friant Dam during the 1950s and subsequent diversion of water from the San Joaquin River for agricultural irrigation led to the extinction of the spring salmon run and a decline in other native fish populations above the Merced River (McBain and Trush, Inc., 2002). In 2006, following an 18-year lawsuit, the U.S. Departments of the Interior and Commerce, the Natural Resources Defense Council, and the Friant Water Users Authority reached a settlement designed to restore the native fisheries (Natural Resources Defense Council versus Kirk Rodgers, Stipulation of Settlement, 2006). The settlement resulted in the formation of the San Joaquin River Restoration Program (SJRRP), for which Federal funding was approved in 2009 (San Joaquin River Restoration Program, 2012). 
The overall goal of the SJRRP is to restore the natural ecology along the San Joaquin River to a degree that restores and maintains salmon and other fish populations. Furthermore, the goal of habitat restoration is to be sought while reducing or avoiding negative water-supply effects to the long-term Central Valley Project contractors in the Friant Division (McBain and Trush, Inc., 2002).

Increased flows in the river, particularly during the spring salmon run, are a key component of the settlement agreement and the restoration effort. One potential consequence of these increased river flows, however, is the exacerbation of existing irrigation drainage problems through increased seepage from the river along presently losing reaches or reduced groundwater discharge to the river along presently gaining reaches. Historically, the San Joaquin River between Mendota and the confluence with the Merced River typically was underlain by a water table within 10 feet (ft) of the land surface. These shallow water-table conditions require a combination of careful irrigation management and artificial drainage to avoid substantial inundation of crop roots and associated effects on crop health.

To better understand the potential effects of restoration flows on these existing drainage problems, the U.S. Geological Survey (USGS), in cooperation with the U.S. Bureau of Reclamation (Reclamation), developed a groundwater flow model (SJRRPGW). This model simulates the groundwater flow system, the surface-water flow system, and the interaction between the two. The SJRRPGW is designed to meet the short-term needs of the SJRRP, which include preliminary evaluations of (1) the groundwater monitoring network; (2) areas most susceptible to developing high water-table conditions during restoration flows; (3) water-table conditions during various future climatic conditions; (4) the relative effectiveness of proposed actions to reduce negative effects on crop; and (5) potential hydrologic effects of various reachspecific projects.

\section{Purpose and Scope}

This report documents the development and calibration of the SJRRPGW, which simulates the groundwater and surfacewater flow systems and the interaction between the two. The SJRRPGW domain is the area within 5 miles (mi) of a 150-mi reach of the San Joaquin River and adjacent bypass system from Friant Dam to the Merced River (fig. 1). Vertically, the SJRRPGW includes the aquifer system above the Corcoran Clay Member of the Tulare Formation, or about the upper $250 \mathrm{ft}$ of aquifer-system material in the area.

The SJRRPGW was developed as part of a USGS study supporting the SJRRP Seepage Sub-Group. The SJRRPGW was developed to estimate the potential effects of restoration flows on agricultural lands and to evaluate the relative capabilities of proposed SJRRP actions to reduce these effects.
In addition, the study seeks to determine areas within the hydraulic influence of the San Joaquin River. These areas will be vulnerable to seepage effects from restoration flows and are most susceptible to developing shallow groundwater conditions that could harm crops. This study also uses the SJRRPGW to estimate historical groundwater conditions in areas without historical observation records. These historical groundwater conditions can be used to evaluate the groundwater-elevation thresholds developed as part of the SJRRP Seepage Management Plan.

The Central Valley Hydrologic model (CVHM) (Faunt, 2009), from which the lateral and lower boundary conditions for the SJRRPGW were derived, has a model-grid spatial resolution that is too low to meet most needs of the SJRRP. For example, many subreaches of the San Joaquin River where the model will be utilized are only a few miles long and would be represented by only a few CVHM cells; the refined SJRRPGW represents these areas in much higher resolution. In addition to the model grid, several other aspects of the hydrologic system were refined spatially and improved within the SJRRPGW, including the sediment-texture distribution, stream and bypass network, water-budget subregions, land use, and surface-water deliveries. The SJRRPGW model is limited to the current timeframe of the CVHM, which is from 1961 to 2003.

\section{Study Area}

The study area (fig. 1) is in the San Joaquin Valley in California and overlies portions of Fresno, Madera, Merced, and Stanislaus Counties. Land use is predominantly agricultural, but also includes urban and wildlife management areas. The study area is characterized by Mediterranean-like climate with hot and dry summers and cool and damp winters. Average monthly temperatures range from 55 degrees Fahrenheit $\left({ }^{\circ} \mathrm{F}\right)$ in January to $99^{\circ} \mathrm{F}$ in July. The average annual rainfall is 11.4 inches (in.); nearly 90 percent of rainfall occurs between November and April.

\section{Hydrogeology}

\section{General Geologic Setting}

The Central Valley, situated between the Sierra Nevada to the east and the Coast Ranges to the west, is a northwesttrending structural trough (Bartow, 1991). The Sierra Nevada is composed primarily of pre-Tertiary granitic rocks separated from the Central Valley by a foothill belt of marine sediments and metavolcanic rocks. The Coast Ranges are a complex assemblage of rocks, including marine and continental sediments of Cretaceous to Quaternary age (Burow and others, 2004). 


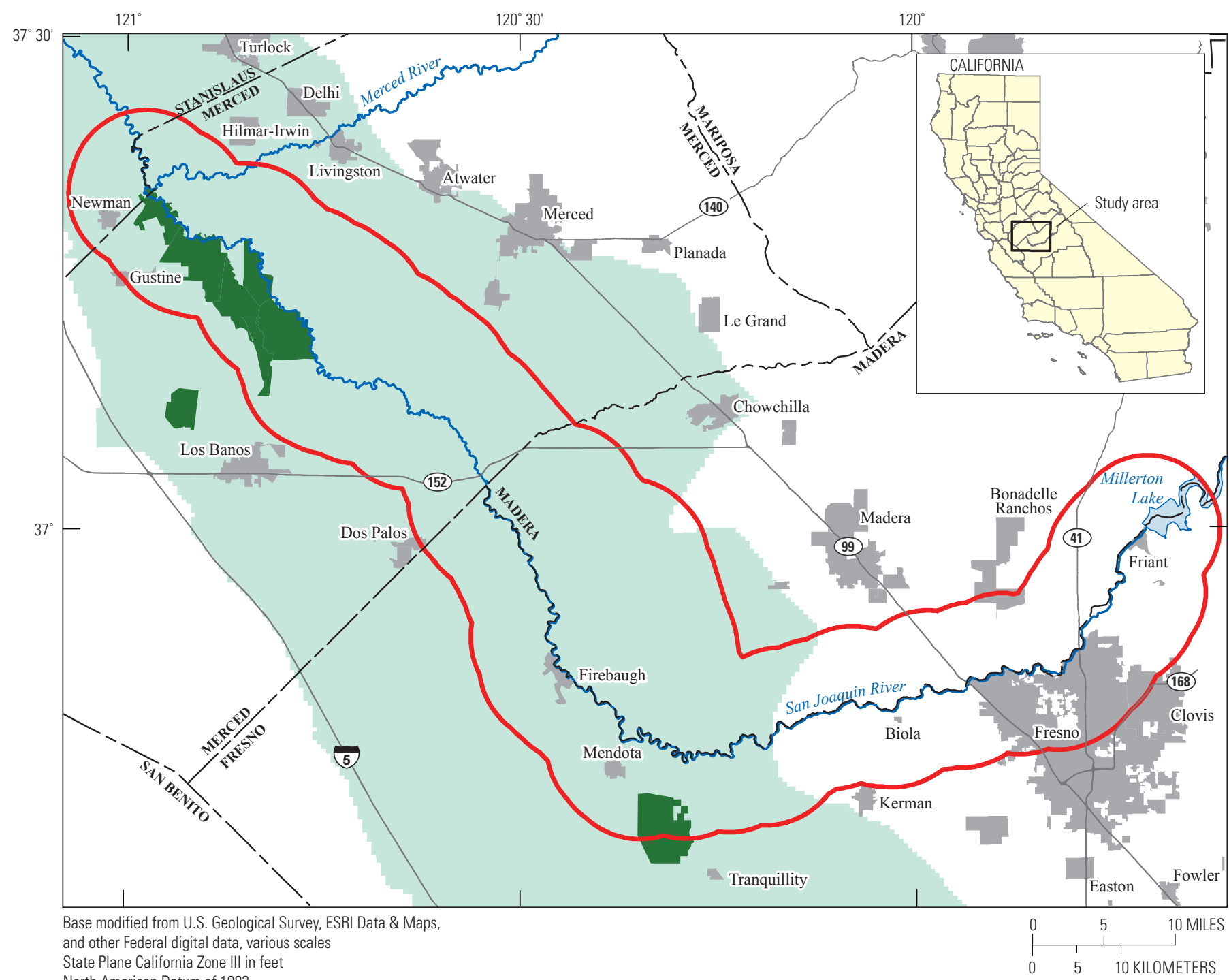

North American Datum of 1983

EXPLANATION

Study area

Reservoir

Wildlife management area
Urban area

Corcoran Clay extent

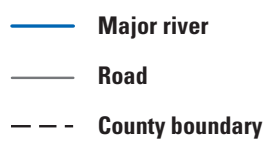

Figure 1. Study area, San Joaquin Valley, California.

The San Joaquin Valley can be divided generally into three physiographic regions - the eastern and western alluvial fans and basin deposits. Alluvial-fan deposits on both sides of the valley are composed predominantly of coarse-grained sediments near the head of each fan that become finer grained toward the valley trough. The sediments in the eastern alluvial fan generally are coarser than those west of the San Joaquin River because the source rocks and watershed characteristics differ. Basin deposits in the region are a combination of coarse-grained channel deposits and fine-grained deposits from flood events (Burow and others, 2004).

The study area is dominated by shallow unconsolidated deposits of gravel, sand, silt, and clay, primarily in the form of alluvium derived from granitic sources to the east and marine sources to the west. Other types of sedimentary deposits in the study area include lacustrine and marsh deposits, dune sands, channel deposits, and flood-basin deposits. Along the valley trough, alluvium derived from the Coast Ranges intermingles with material derived from the Sierra Nevada (Belitz and Heimes, 1990). Sedimentary formations are not clearly delineated in the study area but likely form a sequence of overlapping terrace and alluvial-fan systems (Marchand and Allwardt, 1981) for an area north of the study area. This sequence of deposits indicates cycles of alluviation, soil formation, and channel incision influenced by climatic fluctuations and associated glaciation in the Sierra Nevada (Bartow, 1991). 
The Corcoran Clay (fig. 1), which defines the lower extent of most of the study area, is an extensive lacustrine diatomaceous-clay deposit, spanning about two thirds of the San Joaquin Valley. The Corcoran Clay is a Member of the Tulare Formation (Croft, 1972) and has been correlated with the E-clay (Page, 1986). Page (1986) used results of previous work and a limited number of well logs and geophysical logs to map the areal extent of this regional unit. In the study area, the eastern extent of the Corcoran Clay roughly parallels the valley axis of the San Joaquin River. The top of the Corcoran Clay is between 85 and $260 \mathrm{ft}$ below land surface, and the unit has a thickness from 0 to $120 \mathrm{ft}$ (Page, 1986).

\section{Sediment-Texture Analysis}

The hydraulic properties of the aquifer system in the study area were estimated on the basis of the distribution of sediment texture, or facies, derived from drillers' logs. The texture distribution was interpolated using a geostatistical approach that determines the probability of transitioning from one facies to another and incorporates factors related to the ways sediments were deposited or their depositional environments (Carle and Fogg, 1996). For this study, these factors included the strike, dip, and mean dimensions of the facies. A number of studies have shown this geostatistical tool, Transition-Probability Geostatistical Software (TPROGS) (Carle, 1999), is valuable for development of geologically plausible subsurface characterizations (Ritzi and others, 1995, 2000; Fogg and others, 1998; Weissmann and Fogg, 1999; Weissmann and others, 1999; Fleckenstein and others, 2006).

The strength of this geostatistical approach is the ability to incorporate geologic interpretation into the modeling process. Lee and others (2007) presented a comparison of modeled geologic heterogeneity in an alluvial-fan setting using two geostatistical simulation techniques - sequential Gaussian and transition probability geostatistics. They showed the sequential Gaussian simulation was unable to capture important geologic characteristics, and the transition probability geostatistical approach was able to create more realistic subsurface simulations.

\section{Sediment-Texture Data}

A database of lithologic information from drillers' logs describing boreholes within the study area was created from that developed for the CVHM (Faunt, 2009). From those logs used for the CVHM, 214 were selected for use in this study. An additional 402 drillers' logs from the California Department of Water Resources (DWR) and from a subset of wells installed for the SJRRP were selected to densify the areal coverage and fill gaps where possible. Sediment descriptions on drillers' logs can be ambiguous and variable; therefore, a rating scheme (Faunt, 2009) was used to select the highest quality logs for inclusion in the database. Sediment descriptions from the logs were discretized into 1 -ft intervals
[0.3 meters (m)], entered into the database, and interpreted as one of four facies - gravel, sand, muddy sand, or clay. The locations of wells used for the TPROGS simulations are well distributed throughout the study area (fig. 2).

\section{Transition-Probability Geostatistical Software Discretization}

The grid resolution of the TPROGS model is designed to accommodate the range of mean transition lengths (the mean lengths in three dimensions of each facies) derived from the available texture data. The model cell dimensions are $0.125 \mathrm{mi}$ by $0.125 \mathrm{mi}$ horizontally and $3.28 \mathrm{ft}(1 \mathrm{~m})$ thick. The grid, which is flat-lying (unlike that for the SJRRPGW model), consists of 600 rows, 350 columns, and 255 layers, resulting in $53,550,000$ nodes. The grid does not include the easternmost part of the study area, from near Fresno to Friant Dam (fig. 2), because borehole data are limited and seepage-related issues are expected to be minor in this area. The lower extent of the TPROGS grid is the top of the Corcoran Clay. About half the TPROGS grid is inactive because of the L-shaped study area. Of the 616 drillers' logs in the database, 550 are within the TPROGS grid.

The study area is divided into four unique depositional environments that were simulated by using four separate TPROGS models (fig. 2). The morphology of the San Joaquin Valley guided the definition of each domain. One domain represents fluvial deposits associated with the San Joaquin River along the valley axis. This domain is flanked by two others representing the distal portions of alluvial fans east and west of the river. Another domain represents the higher-energy depositional environment associated with the proximal (near source) portion of the San Joaquin River alluvial fan.

The first domain, the San Joaquin Proximal (SJProx), is defined as the proximal (near-source) sediments of the San Joaquin River alluvial fan. The domain approximately coincides with subreaches $1 \mathrm{~A}$ and $1 \mathrm{~B}$, or the stretch of the San Joaquin River from Friant Dam to Gravelly Ford (about 12 mi east of Mendota). The second domain, the San Joaquin Distal (SJDist), is defined as the distal (far from source) sediments of the San Joaquin and other eastside alluvial fans; the SJDist domain begins near Gravelly Ford and ends near the confluence with the Merced River. The third domain, the San Joaquin Axial (SJAxial), is the area within $2 \mathrm{mi}$ of the San Joaquin River, beginning near the Chowchilla Bypass Bifurcation Structure (about 8 mi east of Mendota) and ending downstream of the confluence with the Merced River. SJAxial approximates the extent of flood-basin and other fluvial deposits associated with the San Joaquin River. The last domain, the Westside Fans (WSFans), represents the area west of the San Joaquin River composed of alluvial-fan deposits derived from the Coast Ranges. TPROGS models were developed separately for each domain, and the results were merged into a composite sediment-texture model for the study area. 


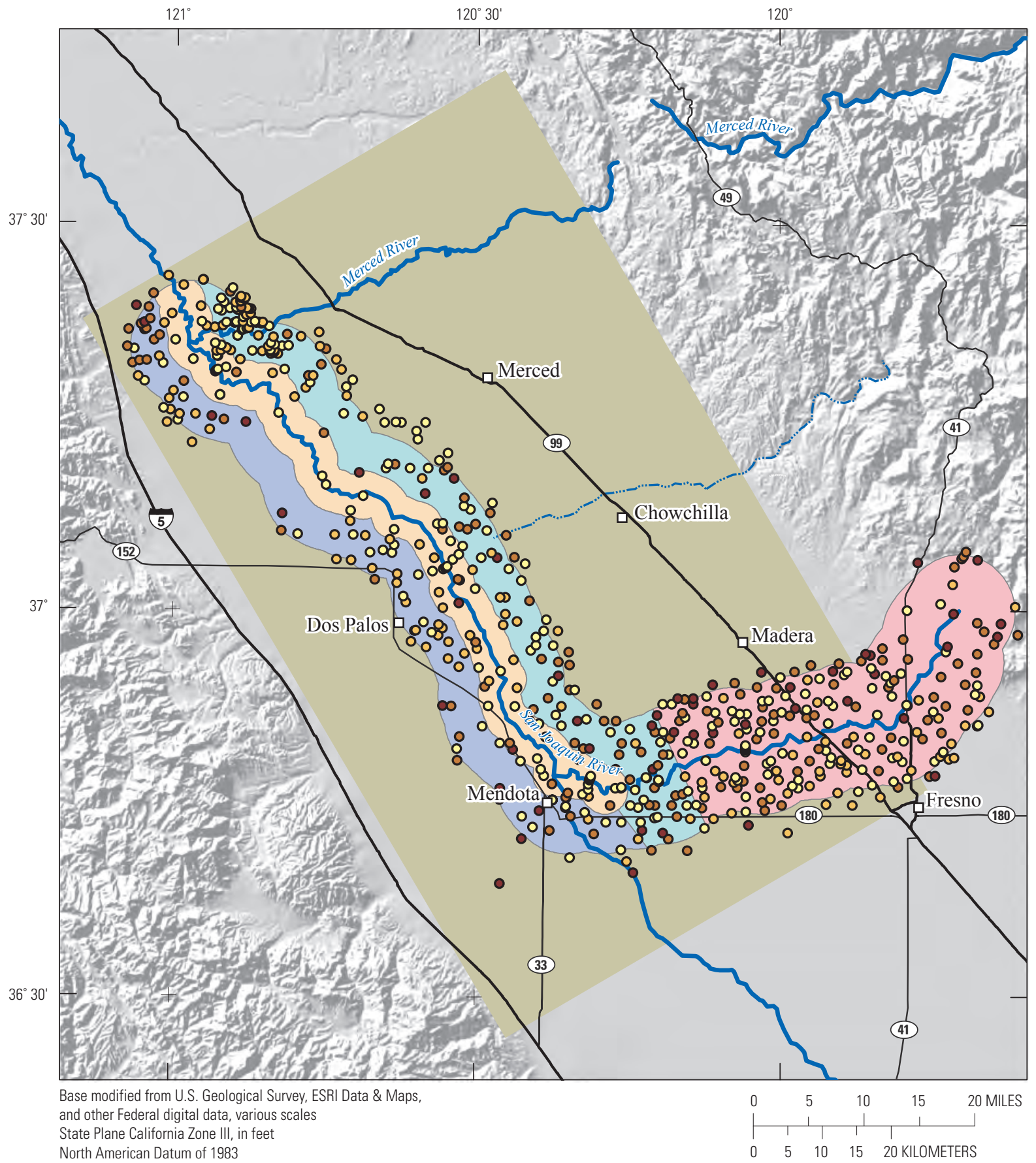

EXPLANATION

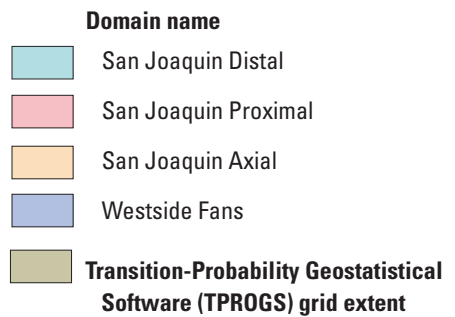

Figure 2. Grid extent, geologic domains, and locations of wells used for the Transition-Probability Geostatistical Software (TPROGS) model, San Joaquin Valley, California. 


\section{Development of Sediment-Texture Models}

Using TPROGS, the probability of one texture class being vertically adjacent to another and the rate at which one class transitions to another was estimated from drillers' logs. TPROGS calculated the vertical transition probabilities between facies, the mean thickness of each facies, and the proportion of each facies for each of the four domains (Carle, 1999). These values were used in developing z-direction Markov chain models for each of the domains (fig. 3).

The "lag" value shown on the abscissa in figure 3 is the vertical distance over which the probability of transitioning from one facies to another (or to itself) is calculated. The diagonal element for each domain (gravel-gravel, sand-sand, and so on) (fig. 3) represents the auto-transition probability or the transition of a facies to itself; thus, the auto-transition probability is related to the facies thickness. The off-diagonal elements (gravel-sand, gravel-muddy sand, and so on) show the cross-transition probabilities, which are the probability that one facies transitions to another as the lag (in terms of thickness or vertical distance) increases. The spatial correlation tendencies of the various facies with respect to each other is shown in figure 3. For example, sand has the highest probability of being on top of gravel in the SJAxial domain, whereas clay has a higher probability of being above gravels in the WSFans domain.

TPROGS uses the Markov chain models to approximate the transition probabilities and uses these in sequential indicator simulations, which were used for generation of multiple realizations of facies distribution that are equally probable (Carle and Fogg, 1996). The results from this process were smoothed using simulated annealing, which preserves cross-correlations between sediment types that can affect preferential flow (Fogg and others, 1998).

Markov chain models were also developed for the lateral principal directions ( $\mathrm{x}$ and $\mathrm{y}$ ); these models are more difficult to develop because information about lengths of horizontal facies is sparse, and boreholes typically are too far apart to make reasonable correlations, particularly in alluvial settings. Different methods have been applied in the region for estimation of lengths of horizontal facies. Weissmann and Fogg (1999), in work done on the Kings River Fan in the San Joaquin Valley, mapped and measured C-horizon soil textures to get estimates of the mean lengths of each of their facies categories. Phillips and others (2007), in work done along the Merced River in the San Joaquin Valley, applied a scaling factor to estimate the lateral mean lengths on the basis of the vertical means lengths. The scaling factor was based on the interpreted horizontal continuity of sediments between wells and previous reports of the sedimentary geology of the area. Lateral mean lengths were interpreted to be 200 times greater in the dip direction and 100 times greater in the strike direction than the facies thicknesses observed in the borehole data.
For this study, lateral facies dimensions were derived on the basis of a more physically based approach of Weissmann and Fogg (1999).

The Markov chain model for the SJProx domain was developed using data from 158 wells. Facies proportions, vertical mean lengths, and transition probabilities were calculated using borehole data from these wells (table 1). Lateral mean lengths were adopted from the TPROGS model developed by Weissmann and Fogg (1999) (table 1) for deposits of the Kings River alluvial fan. Although the San Joaquin River alluvial fan is smaller than the Kings River fan, the size of the fan has been constrained by its location in the San Joaquin Valley. Lower subsidence rates and the connection of the San Joaquin River to local base level have limited the overall fan size (Weissmann and others, 2005). However, because the drainage area in the Sierra Nevada above the San Joaquin River alluvial fan is comparable to that for the Kings River, it is reasonable to expect similar characteristics of sediment supply and stream discharge.

Table 1. Proportions and mean lengths used in the TransitionProbability Geostatistical Software (TPROGS) model for each geologic domain in the San Joaquin Valley study area, California.

[Proportion expressed as fraction of 1]

\begin{tabular}{|c|c|c|c|c|}
\hline \multirow{2}{*}{ Facies } & \multirow{2}{*}{ Proportion } & \multicolumn{3}{|c|}{$\begin{array}{l}\text { Mean length } \\
\text { (meters) }\end{array}$} \\
\hline & & $\mathbf{x}$ & $\mathbf{Y}$ & Z \\
\hline \multicolumn{5}{|c|}{ San Joaquin Proximal (SJProx) } \\
\hline Gravel & 0.03 & 650 & 200 & 4.7 \\
\hline Sand & 0.47 & 1,500 & 625 & 4.2 \\
\hline Muddy sand & 0.14 & 800 & 400 & 3.9 \\
\hline Clay & 0.36 & 973 & 439 & 3.6 \\
\hline \multicolumn{5}{|c|}{ San Joaquin Distal (SJDist) } \\
\hline Gravel & 0.01 & 640 & 200 & 4.6 \\
\hline Sand & 0.41 & 1,300 & 550 & 3.7 \\
\hline Muddy sand & 0.14 & 820 & 410 & 4.0 \\
\hline Clay & 0.44 & 1,171 & 527 & 4.3 \\
\hline \multicolumn{5}{|c|}{ San Joaquin Axial (SJAxial) } \\
\hline Gravel & 0.03 & 200 & 350 & 3.7 \\
\hline Sand & 0.51 & 330 & 800 & 3.9 \\
\hline Muddy sand & 0.17 & 210 & 430 & 2.5 \\
\hline Clay & 0.29 & 157 & 366 & 2.8 \\
\hline \multicolumn{5}{|c|}{ Westside Fans (WSFans) } \\
\hline Gravel & 0.11 & 750 & 230 & 5.6 \\
\hline Sand & 0.41 & 2,150 & 900 & 7.5 \\
\hline Muddy sand & 0.08 & 640 & 540 & 3.1 \\
\hline Clay & 0.41 & 1,112 & 492 & 5.6 \\
\hline
\end{tabular}



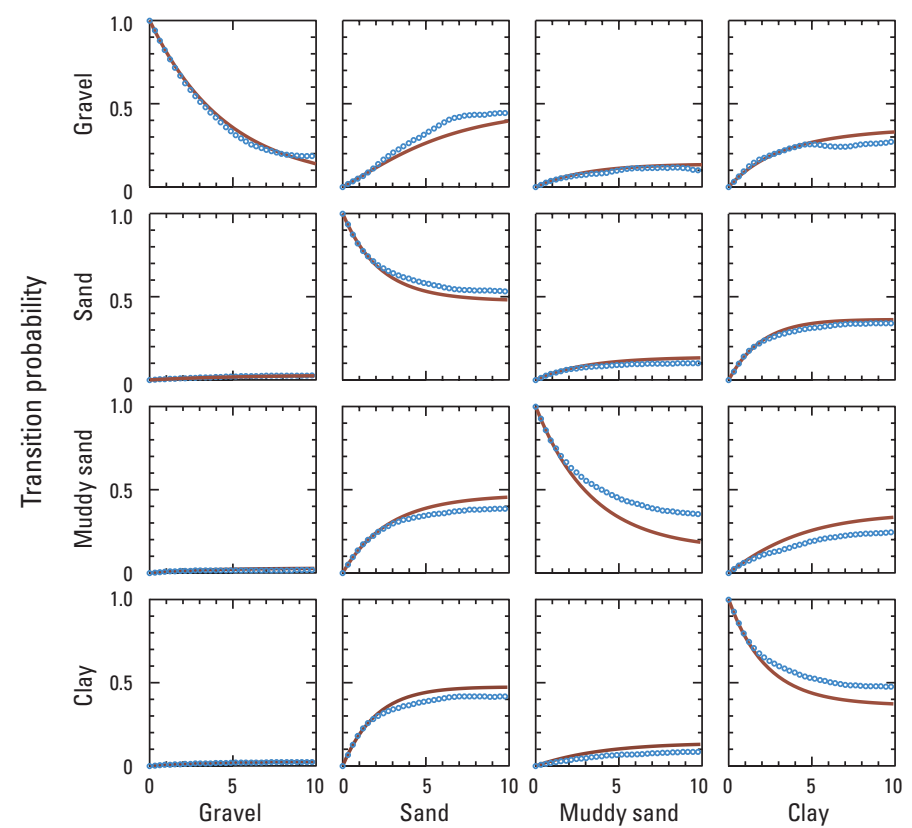

San Joaquin Proximal domain
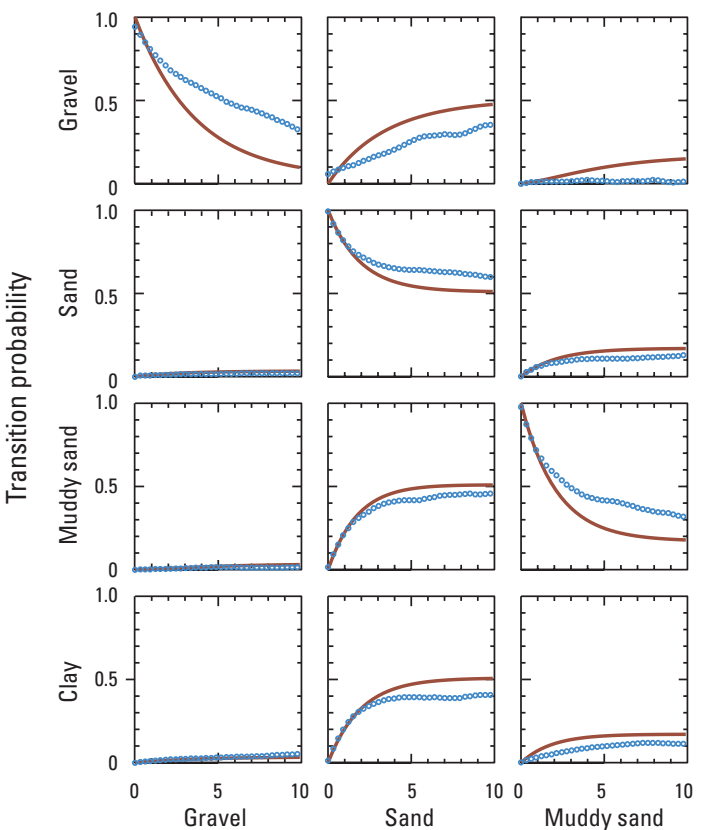

San Joaquin Axial domain
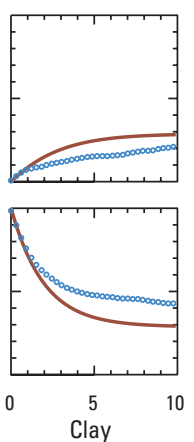
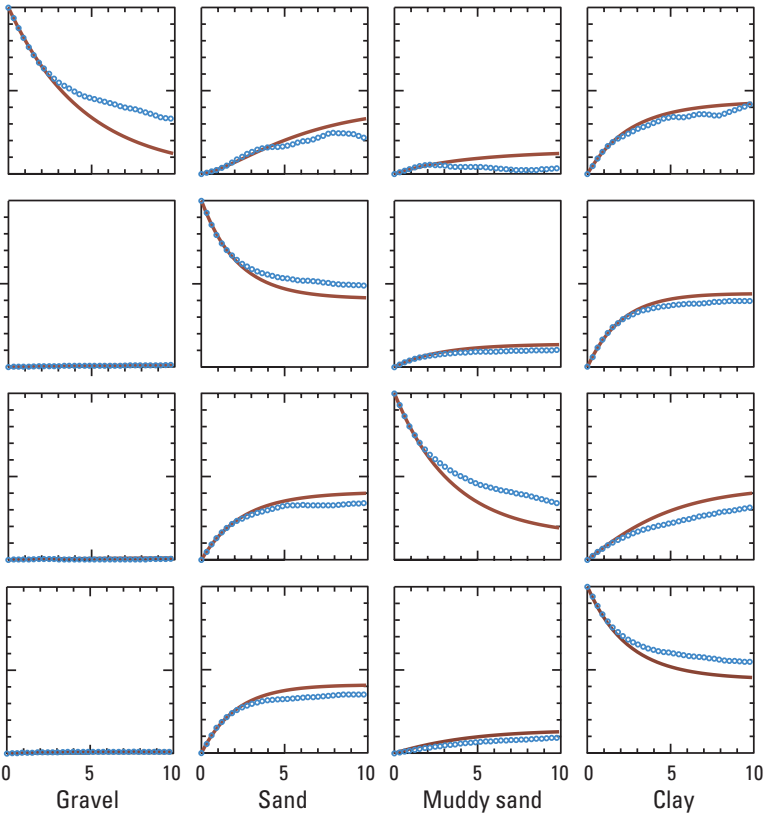

San Joaquin Distal domain
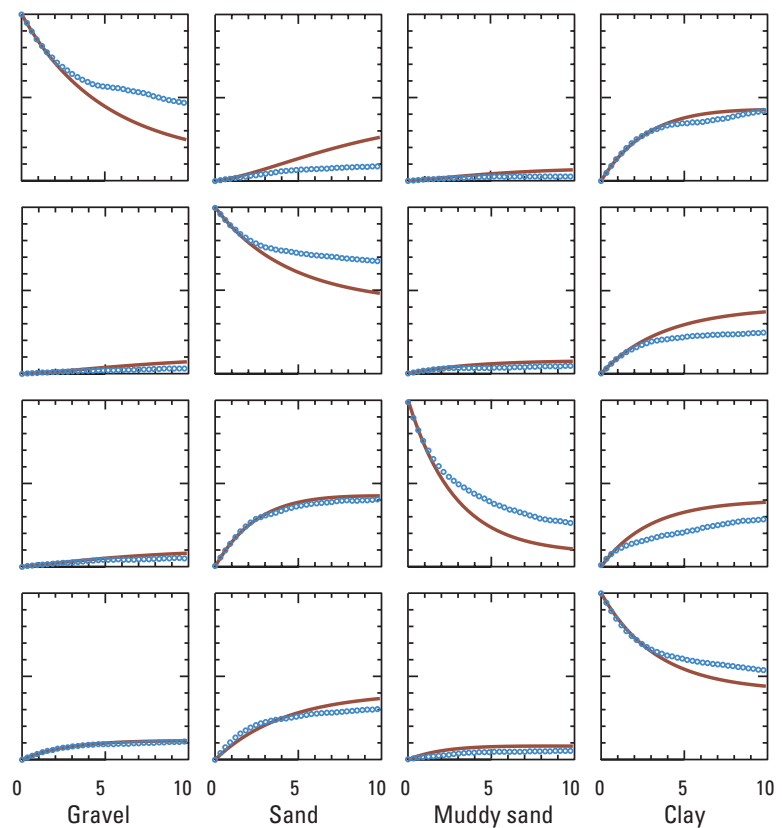

Westside Fans domain

EXPLANATION

Measured from borehole data

Markov chain mode

Figure 3. Relation between vertical transition probabilities for each facies and geologic domain measured from borehole data and simulated using Markov chain models, San Joaquin Valley study area, California. 
The lateral components of the Markov chain models for the SJDist (196 wells), SJAxial (93 wells), and WSFans (103 wells) domains were developed on the basis of those derived for the SJProx domain. Lateral mean facies lengths were scaled from the SJProx values by the ratio of the vertical mean facies lengths. For example, the mean thickness of clay in SJProx is $11.8 \mathrm{ft}$ and in SJDist is $14.1 \mathrm{ft}$, or about 20 percent thicker. Accordingly, the lateral mean facies lengths for SJDist were assumed to be about 20 percent greater than those for SJProx. This process was repeated for each of the facies and domains (table 1). The results are similar to those obtained using the method of Phillips and others (2007) but with greater variability from facies to facies.

These three-dimensional Markov chain models of the four domains approximated the transition probabilities used for sequential indicator simulations. The four domains were then merged into a composite realization (fig. 4). A single composite realization represents one of many possible distributions of the defined facies. A key advantage of this method is that the same input can be used to generate hundreds of realizations, which provide the opportunity to explore a wide range of equally probable facies distributions. For this study, a single composite realization was randomly selected to represent the facies distribution in the study area.

Each of the composite realizations honor the overall proportions of hydrofacies determined from well logs in each domain (table 1) and their depositional alignments. For example, the SJAxial domain (fig. 4) contains a greater proportion of the sand facies than the flanking domains because the sediments in this geologic domain were deposited in a direction parallel to the river, orthogonal to the other domains.

\section{Hydrologic Setting}

\section{Surface Water}

The major surface-water feature in the study area is the San Joaquin River. The study area also contains several other streams as well as flood-control bypass channels and structures. The streamflow network in the study area (fig. 5) was mapped using a combination of aerial photographs and the 1:24,000 National Hydrography Dataset (NHD) (U.S. Geologic Survey, 2011). Reclamation has divided the San Joaquin River into five major planning reaches (fig. 5).

Reach 1 extends 37 river miles from Friant Dam to Gravelly Ford. Reach 2 extends 21 river miles from Gravelly Ford to Mendota Dam. Reach 3 extends 25 river miles from Mendota Pool to Sack Dam. Reach 4 extends 56 river miles from Sack Dam to the Eastside Bypass confluence. Reach 5 extends 17 river miles from the Eastside Bypass confluence to the Merced River confluence. Some of these reaches are further divided into subreaches. Note, the area of concern for seepage-related issues is from Mendota to the confluence of the Merced River, representing much of the study area (Reaches $2 \mathrm{~B}$ through 5).

Inflows for the 10 streams or canals entering the study area (table 2 and fig. 5) were obtained from a variety of sources. Inflow for the San Joaquin River and the North Fork Lower Kings River (also known as James Bypass) were obtained from the USGS National Water Information System (NWIS). Inflow to the Mendota Pool from the Delta-Mendota Canal was obtained from the CALSIM Water Resources Simulation Model (California Department of Water Resources, 2011a). For the other seven locations, inflows were specified

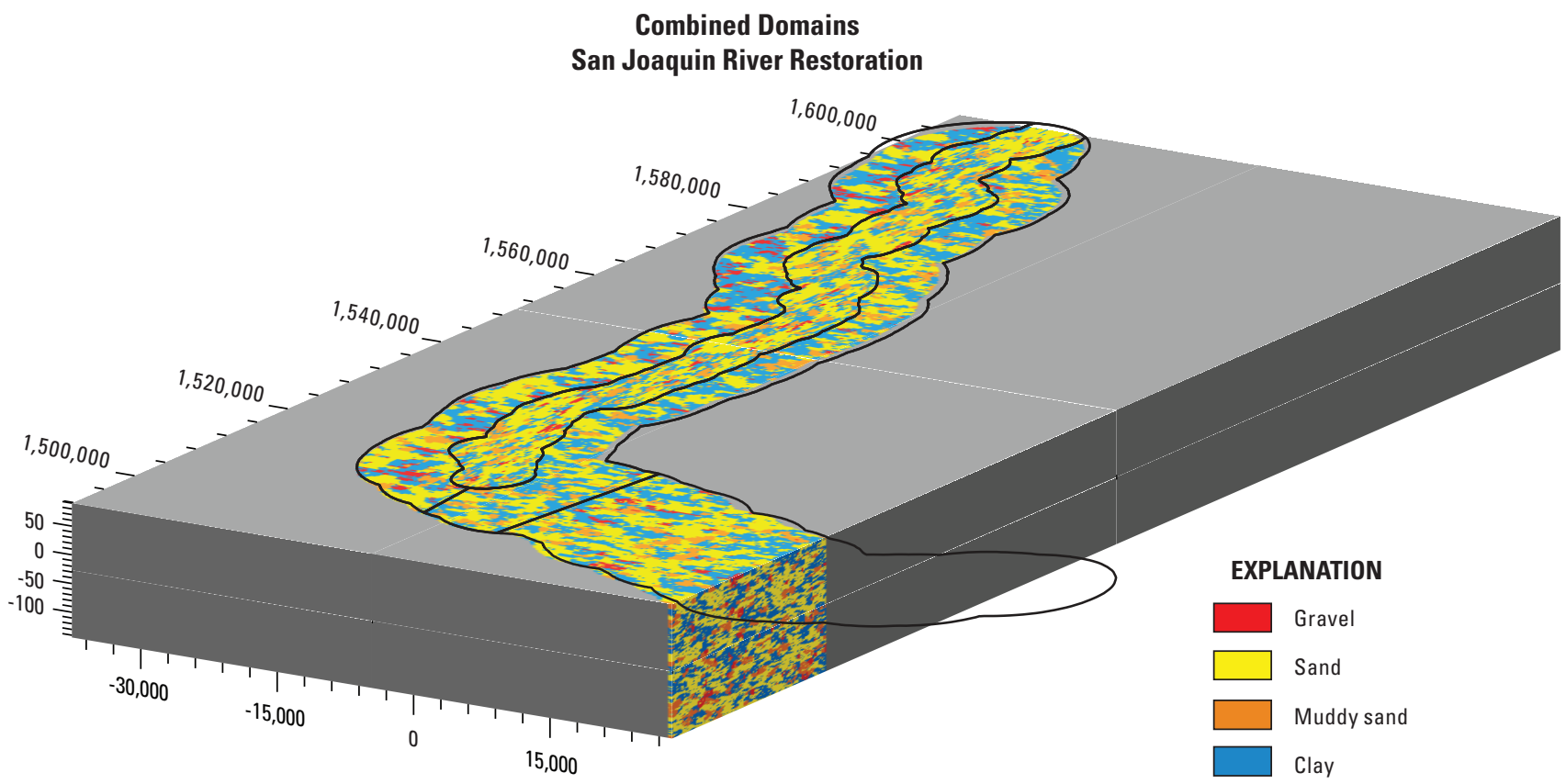

Figure 4. Combined model of sediment-texture distribution derived from Transition-Probability Geostatistical Software (TPROGS) of four geologic domains in the San Joaquin Valley, California. 
Table 2. Streamflow data available in study area, San Joaquin Valley, California.

[Abbreviations: Calif., California; CALSIM, CALSIM Water Resources Simulation Model; CVHM, Central Valley Hydrologic Model; mm/yyyy, month/year; USGS, U.S. Geological Survey; +, plus; -, minus; - , no data]

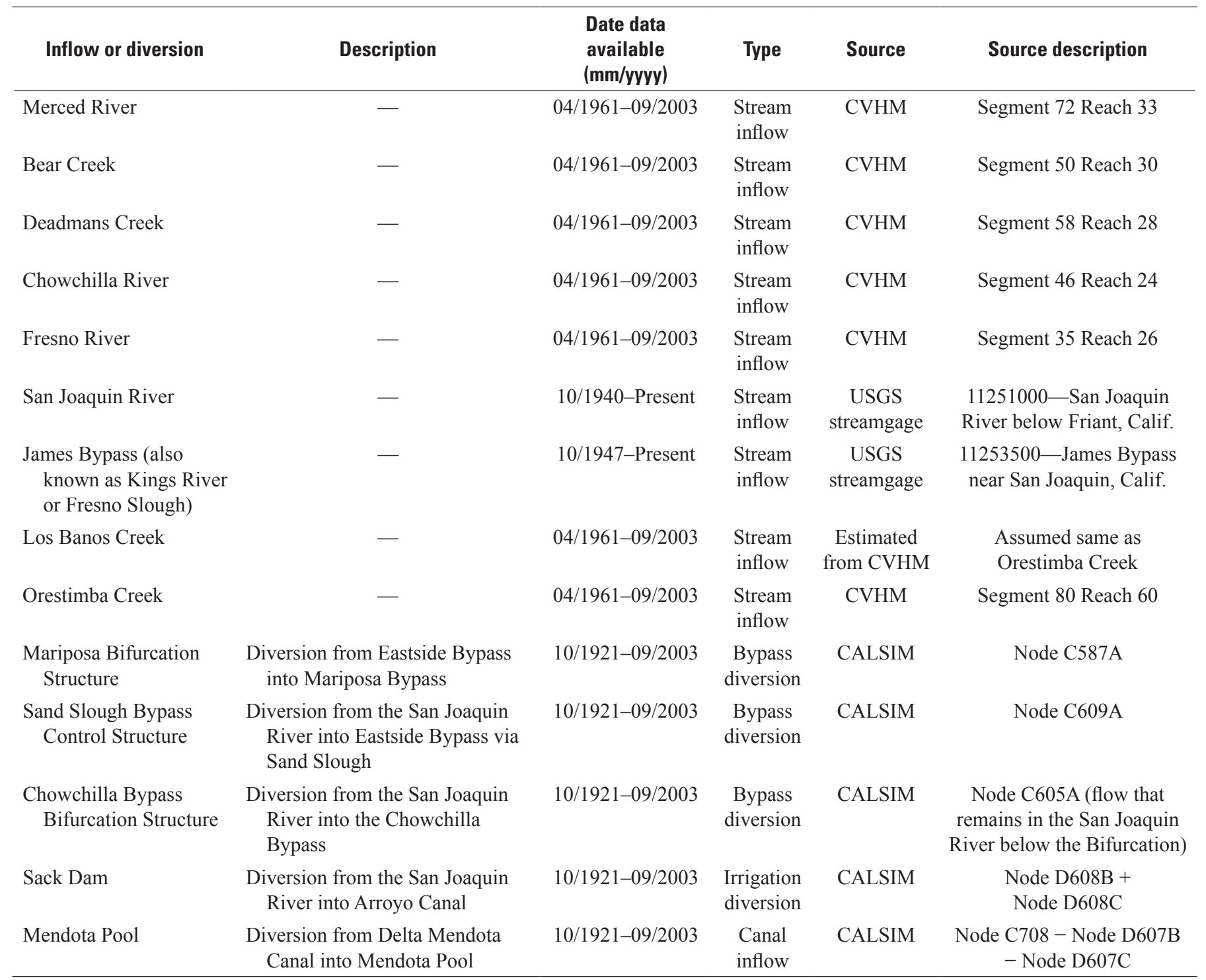




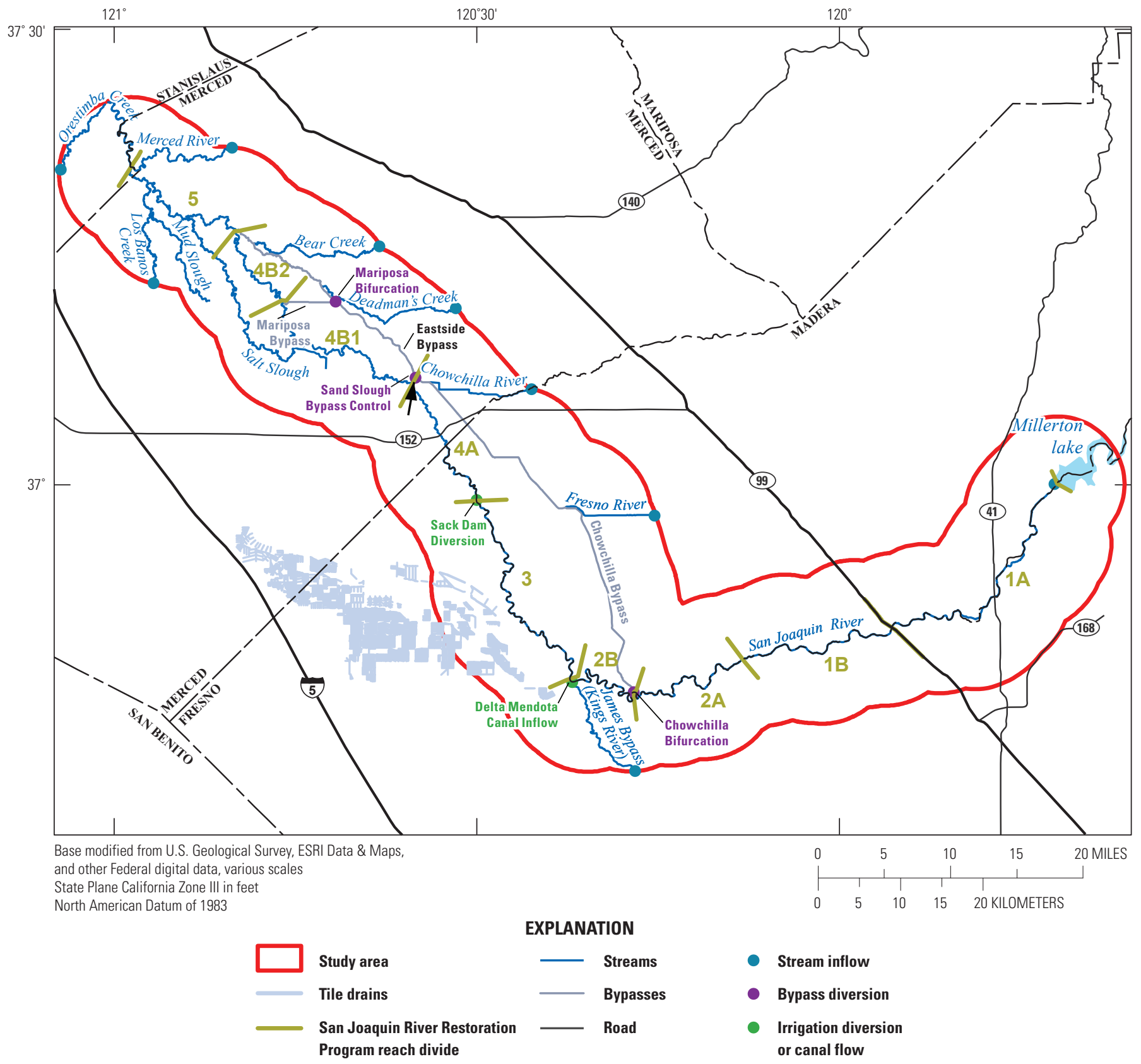

Figure 5. Streamflow network in the study area, San Joaquin Valley, California. 
as the simulated flows for these streams from the CVHM at the study-area boundary.

The study area has three major bypass diversion structures - Chowchilla Bypass Bifurcation Structure, Sand Slough Bypass Control Structure, and Mariposa Bifurcation Structure (fig. 5). In addition, there is an irrigation diversion on the San Joaquin River at Sack Dam. Data for these bypasses and the irrigation diversion also were obtained from the CALSIM model (table 2).

The average annual stream inflow to the study area from 1961 to 2003 is approximately 1.4 million acre-feet (acre-ft); 68 percent of this inflow occurs during February through June (fig. 6). The San Joaquin and Merced Rivers contribute 65 percent of the total inflow into the study area.

The average annual stream outflow from the study area can be approximated by the streamgage on the San Joaquin River near Newman, Calif. (USGS site identification number 11274000), which is downstream from the Merced River confluence. The average annual stream outflow from the study area from 1961 to 2003 is also approximately 1.4 million acre-ft.

\section{Groundwater}

\section{Groundwater-Elevation Database}

A groundwater-level database consisting of almost 90,000 records for 2,800 wells within the SJRRP study area was compiled for the period 1920 through 2009. More than 90 percent of the available records represent the period after 1960. The frequency of water-level measurements for any particular well generally is limited to biannual spring and fall measurements, although monthly, weekly, and daily records are available for a few wells for short periods.

Approximately 18 percent of the wells in the groundwater-level database are classified as observation wells. Wells reportedly used for groundwater withdrawal, including irrigation, domestic, stock, and public supply, account for about 65 percent of the wells. The remaining 17 percent of the wells in the database are classified as either unused production wells or are lacking specific information regarding their intended purpose. Water-level records were obtained from the California Department of Water Resources (DWR) Water Data

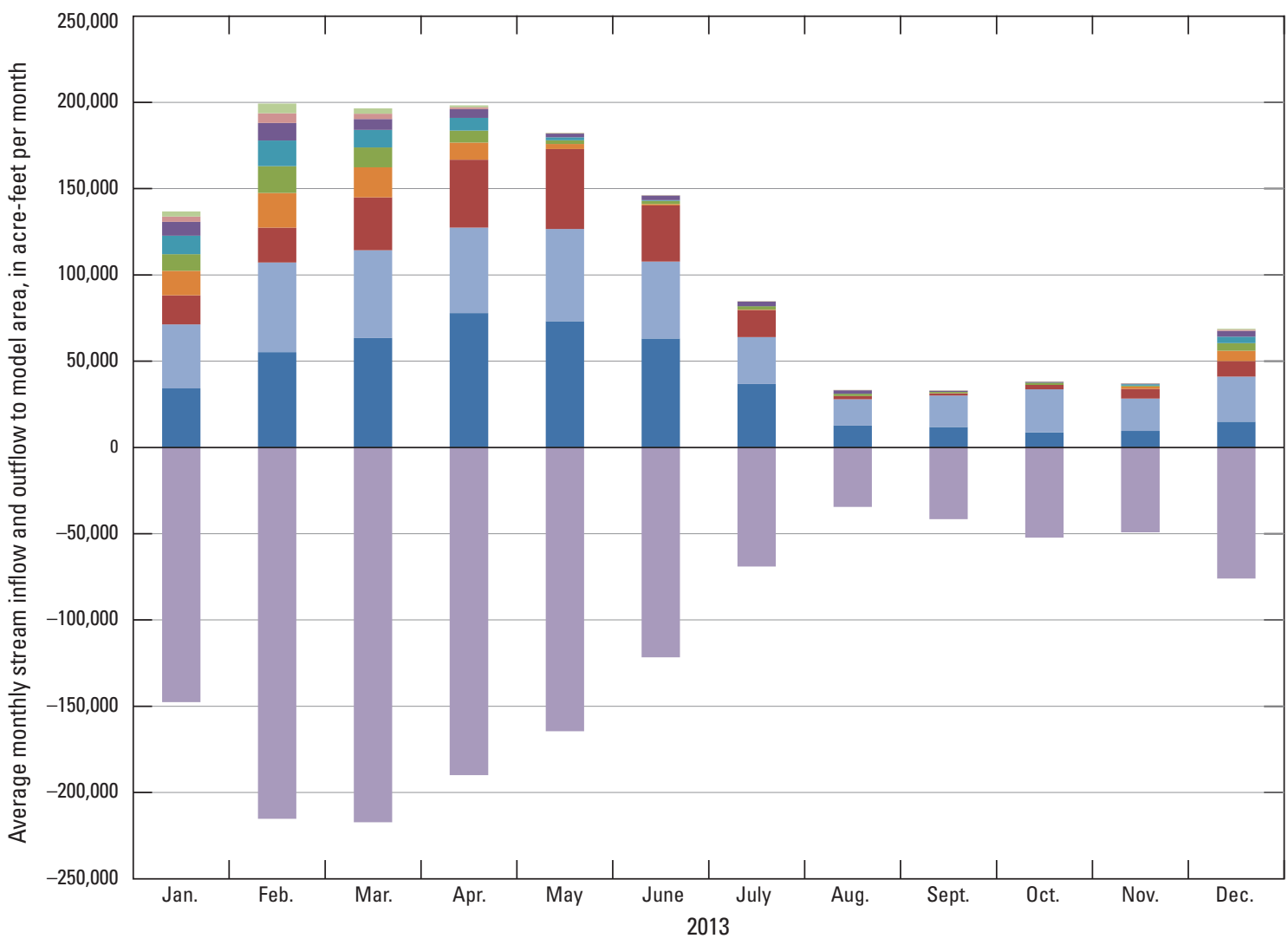

EXPLANATION

Los Banos

Orestimba

Chowchilla

Deadmans

Fresno

Bear

Kings

Merced

San Joaquin

Outflow

Figure 6. Monthly average stream inflow and outflow to study area, San Joaquin Valley, California. 
Library (WDL) online database, the USGS NWIS database, the Mendota Pool Group (MPG), and the Central California Irrigation District (CCID). The database compiled for this project also includes approximately 600 water-level measurements through 2009 that were obtained from 62 SJRRP observation wells installed and monitored by Reclamation beginning in the spring of 2008 .

\section{Groundwater Elevation and Movement}

The history of hydrologic and associated water-table changes in and around the study area provides useful information on areas vulnerable to shallow water-table conditions. Agricultural development began in the late 1800s but accelerated rapidly post-World War II (Bertoldi and others, 1991). Through the 1960s, most water used for irrigation was groundwater, and this was reflected in a long-term decline of groundwater elevations in some areas (Belitz and Heimes, 1990).

Although groundwater elevations declined throughout much of the region within and surrounding the study area, shallow groundwater conditions persisted in some areas near the San Joaquin River, particularly on the west side (U.S. Bureau of Reclamation, 1962). Part of the explanation for these shallow groundwater areas is that surface water is the primary water supply for irrigation as opposed to groundwater in these areas as well as fine-grained soils in the shallow subsurface. Riparian use of water from the San Joaquin River was the local norm before Friant Dam was constructed and flows in the river diminished; in exchange for the loss of this source of irrigation water, deliveries of surface water from the Sacramento-San Joaquin Delta via the Delta-Mendota Canal were made available, starting in 1951, to the San Joaquin River Water Authority Exchange Contractors, including the CCID, San Luis Canal Company, and Columbia Canal Company (McBain and Trush, Inc., 2002). Agricultural tile drains were installed in the 1950s and 1960s to help manage many of these areas (fig. 5) (J. McGahan, Summers Engineering, written commun, 2002; S. Styles, Irrigation Training and Research Center, written commun., 2002).

Maps of depth to the water table (DTW) for selected years were created by using an ordinary kriging interpolation method. Ordinary kriging takes into account two important aspects of estimation, distance and clustering. The basic technique for ordinary kriging uses a weighted average of neighboring samples (well locations with corresponding DTW data) to estimate unknown values of DTW at neighboring locations. The results were optimized by applying variogram models (Gaussian, exponential, and spherical) known to work well with spatially continuous data and examining the semivariogram, depicted using a graph that relates the difference between a value at one location and the value at another according to the distance and direction between them. The optimization process resulted in semi-variograms exhibiting a linear behavior near the origin (a straight line could be fit to the first few points on the semi-variogram), and the selection of a spherical variogram model on the basis of the intersection of the straight line and the range of the semi-variogram (Isaaks and Srivastava, 1989).

Semi-variogram models are developed for each dataset to calculate the interpolated DTW (fig. 7). The semivariance depicts how closely the values at a given distance are spatially correlated. This correlation can be inferred from the semivariograms by examining how well the empirical data fits the variogram model. The distance at which each of the modeled variograms begins to reach an asymptote corresponds to the range of the semi-variogram. The range defines the maximum distance at which spatial correlation between given well locations can be estimated. As expected, spatial correlation distance is less for years with sparse well coverage throughout the study area (2006) and greater for years with greater density of well coverage (1981, 1983, and 1988). For example, in 1983, empirical data fits the model line to a distance of approximately 75,000 ft (approximately $14 \mathrm{mi}$ ); in 2006, empirical data fits the model line to less than approximately $50,000 \mathrm{ft}$ (approximately $9 \mathrm{mi}$ ).

The minimum, maximum, and mean difference between interpolated and known values of DTW are shown in table 3. The location of the maximum difference in DTW for all years was in Reach 1A, which is an area where the interpolated surface under estimates the local shallow groundwater conditions of a few wells near the San Joaquin River in an area where the regional water table is relatively deep.

The DTW maps (fig. 8) were created for the fall measurement period (September 15 through November 15) for the years having the greatest number of measurements and (or) the greatest interest with respect to particular climatic conditions. The fall period is relatively unaffected by irrigation, is minimally affected by rainfall, generally has the most available water-level data, and approximates the seasonal low. Available

Table 3. Minimum, maximum, and mean difference between interpolated and known values of depth to water table for a given year, San Joaquin Valley, California.

[Abbreviations: DTW, depth to water table; ft, feet]

\begin{tabular}{ccccc}
\hline Year & Well count & $\begin{array}{c}\text { Minimum DTW } \\
\text { difference } \\
\text { (ft) }\end{array}$ & $\begin{array}{c}\text { Maximum DTW } \\
\text { difference } \\
\text { (ft) }\end{array}$ & $\begin{array}{c}\text { Mean DTW } \\
\text { difference } \\
\text { (ft) }\end{array}$ \\
\hline 1981 & 654 & 0.0 & 22.5 & 1.2 \\
1983 & 837 & 0.0 & 9.1 & 0.4 \\
1988 & 792 & 0.0 & 9.0 & 0.5 \\
1991 & 743 & 0.0 & 11.0 & 0.6 \\
1994 & 789 & 0.0 & 7.4 & 0.6 \\
1999 & 500 & 0.0 & 6.4 & 0.5 \\
2006 & 503 & 0.0 & 5.9 & 0.6 \\
2007 & 302 & 0.0 & 5.2 & 0.5 \\
2008 & 333 & 0.0 & 13.3 & 1.4 \\
2009 & 295 & 0.0 & 5.6 & 0.4 \\
2010 & 289 & 0.0 & 41.8 & 6.8 \\
\hline
\end{tabular}



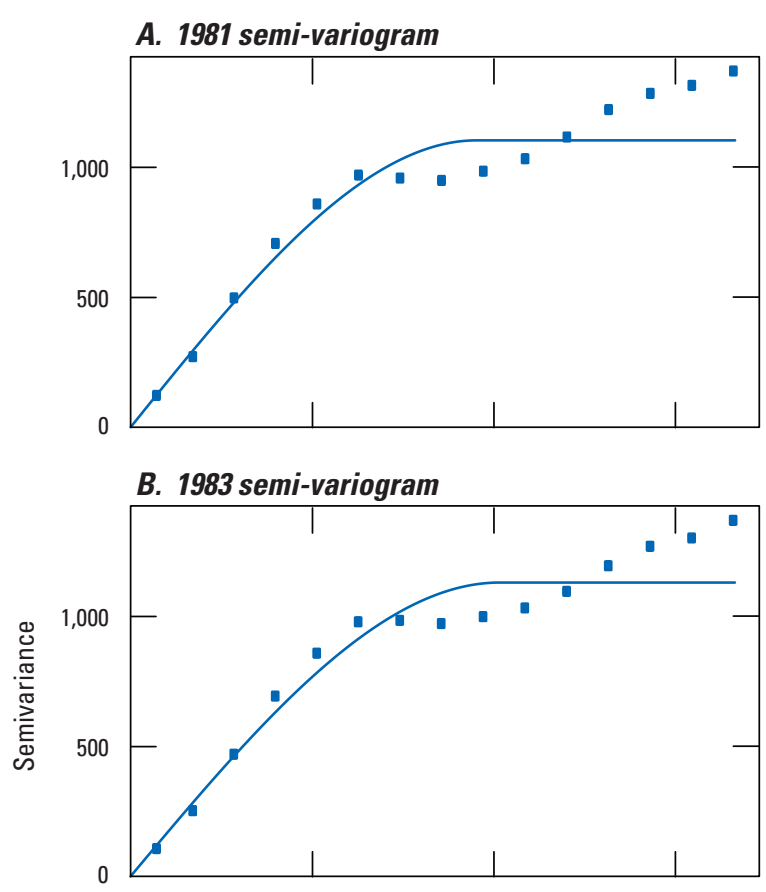

C. 1988 semi-variogram

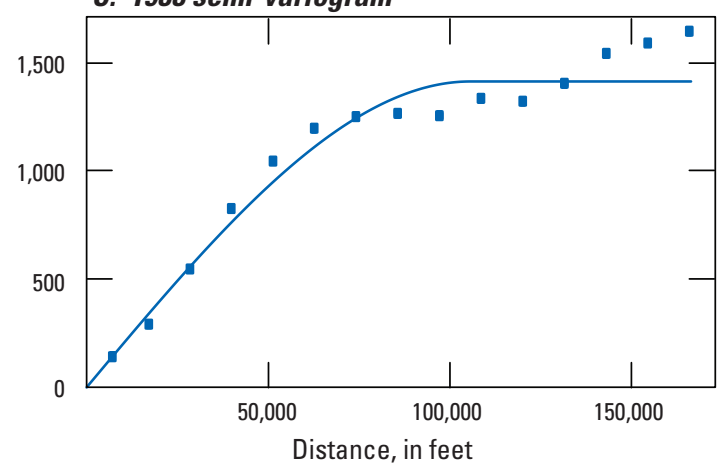

D. 1991 semi-variogram

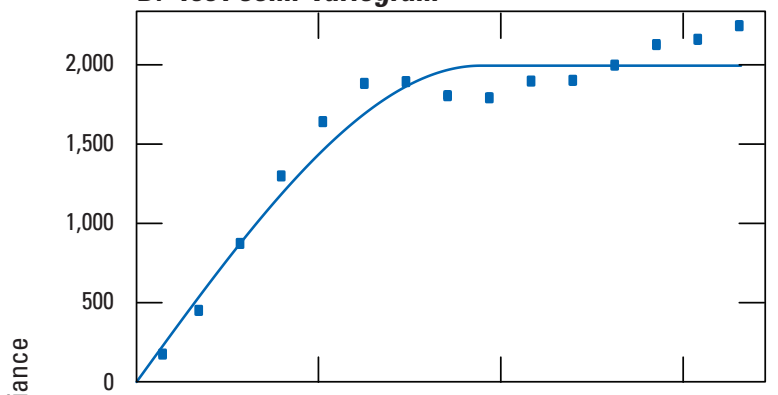

E. 2006 semi-variogram
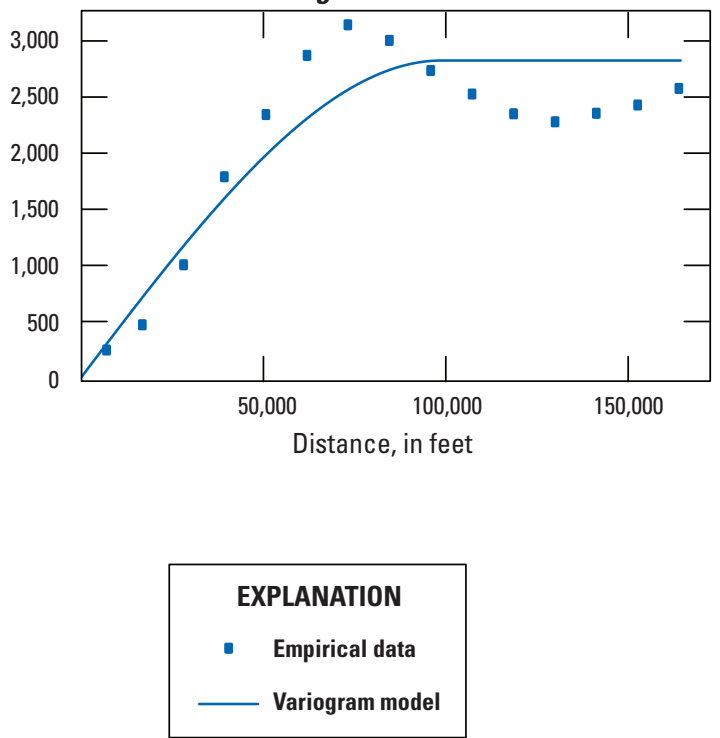

Figure 7. Semi-variogram results corresponding to the kriged depth to water-table maps, San Joaquin Valley, California: $A$, 1981; $B$, 1983; $C, 1988 ; D, 1991 ;$ and $E, 2006$.

water-level data prior to the 1980s are insufficient for mapping DTW below land surface, but data from shallow wells during the 1960s indicate large areas where the DTW was less than $10 \mathrm{ft}$. These areas were predominantly west of the San Joaquin River. Water-year designations (Critical-Low, Critical-High, Dry, Normal-Dry, Normal-Wet, and Wet) were defined by the SJRRP on the basis of the total annual unimpaired runoff at Friant Dam for the water year (October through September) (Natural Resources Defense Council v. Kirk Rodgers, Stipulation of Settlement, 2006).

Substantial deliveries of surface water to the area west of the study area began during the early 1970s with the completion of the California Aqueduct. Accompanied by a large decrease in groundwater pumping, this caused a dramatic recovery of water levels over much of the west side of the valley (Belitz and Heimes, 1990). Because of sparse availability of data, it is not clear if this recovery to the west had a substantial effect on shallow water levels within the study area. Water levels on the east side, however, continued to decline, and by 1981, water levels were much lower on the east side than on the west side (fig. 8A); 1981 was a NormalDry year preceded by a Wet year (1980) and Normal-Wet year (1979). Notably, the shallowest groundwater areas in 1981 are primarily very near to and west of the river, with the exception of areas east of the river in Reaches 4 and 5.

Following 1981, two Wet years caused substantial increases in the water table over most of the study area. The DTW in 1983 indicates recovery of water levels along the eastern margin of the study area toward Chowchilla and Madera and considerable growth in the shallow groundwater areas along the west side and parts of the east side along the river and to the north (fig. $8 B$ ).

Following 1983, there was a range of water-year types; however, a drought started in 1987 with a Dry year. By 1988, also a Dry year, water levels along the eastern margin of the study area had declined, and the area of shallow groundwater had retreated westward; however, the shallow groundwater area remained widespread on the west side (fig. 8C). 


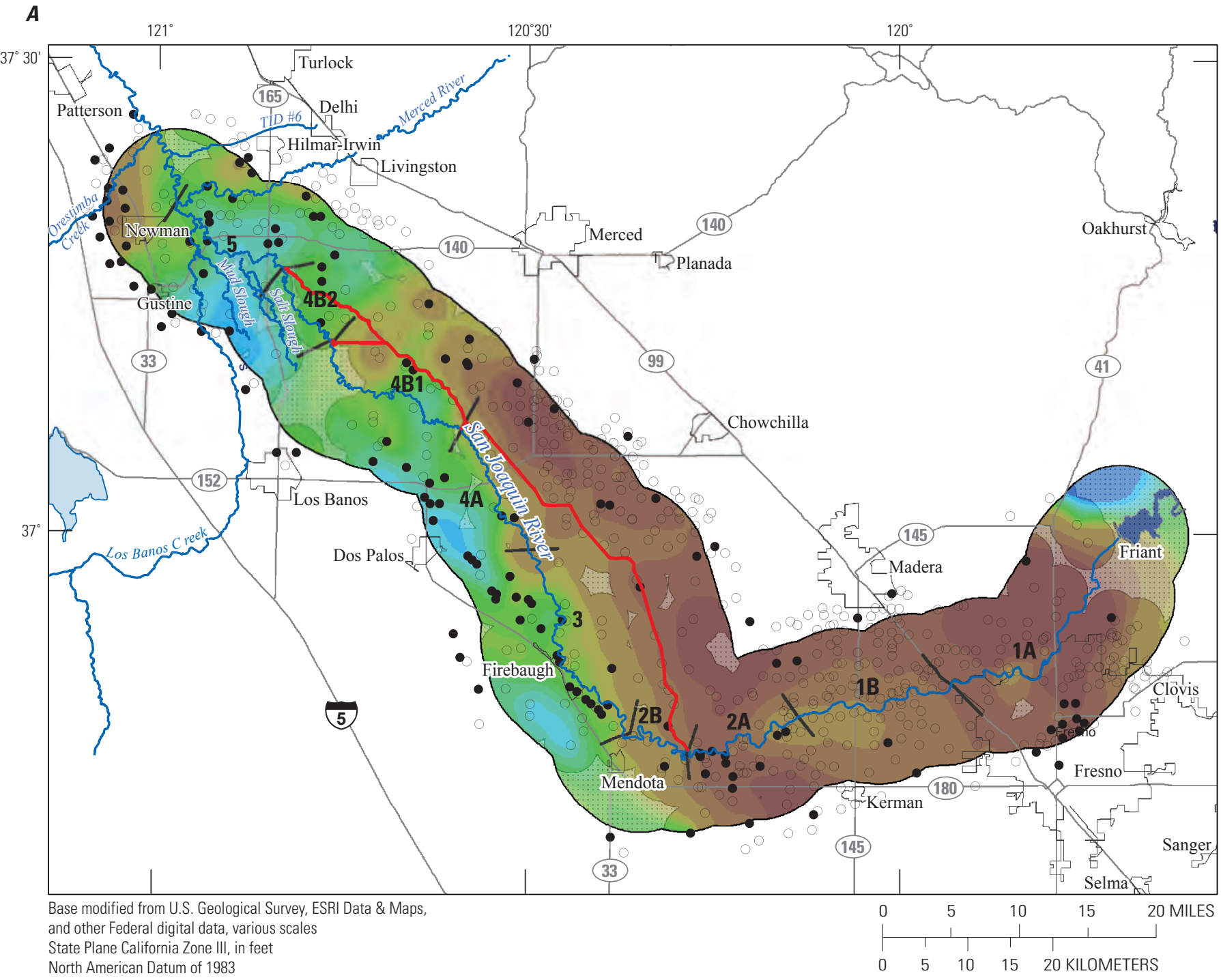

State Plane California Zone III, in feet
North American Datum of 1983

\section{EXPLANATION}

\begin{tabular}{|c|c|c|c|}
\hline \multicolumn{2}{|r|}{ Well information } & \multicolumn{2}{|c|}{ Depth to water table, in feet } \\
\hline - & Known & 0 to 2 & $>16$ to 18 \\
\hline 0 & Unknown & $>2$ to 4 & $>18$ to 20 \\
\hline & Bypasses & $>4$ to 6 & $>20$ to 25 \\
\hline & & $>6$ to 8 & $>25$ to 50 \\
\hline ::::!: & $\begin{array}{l}\text { Area greater than } 2 \text { miles } \\
\text { from a well }\end{array}$ & $>8$ to 10 & $>50$ to 75 \\
\hline & & $>10$ to 12 & $>75$ to 100 \\
\hline & & $>12$ to 14 & $>100$ \\
\hline & & $>14$ to 16 & \\
\hline
\end{tabular}

Figure 8. Interpolated depth to water table in study area, San Joaquin Valley, California: $A$, Fall 1981, a Normal-Dry water year; $B$, Fall 1983, a Wet water year; C, Fall 1988, a Dry water year; D, Fall 1991, a Normal-Dry water year; $E$, Fall 2006, a Wet water year. 


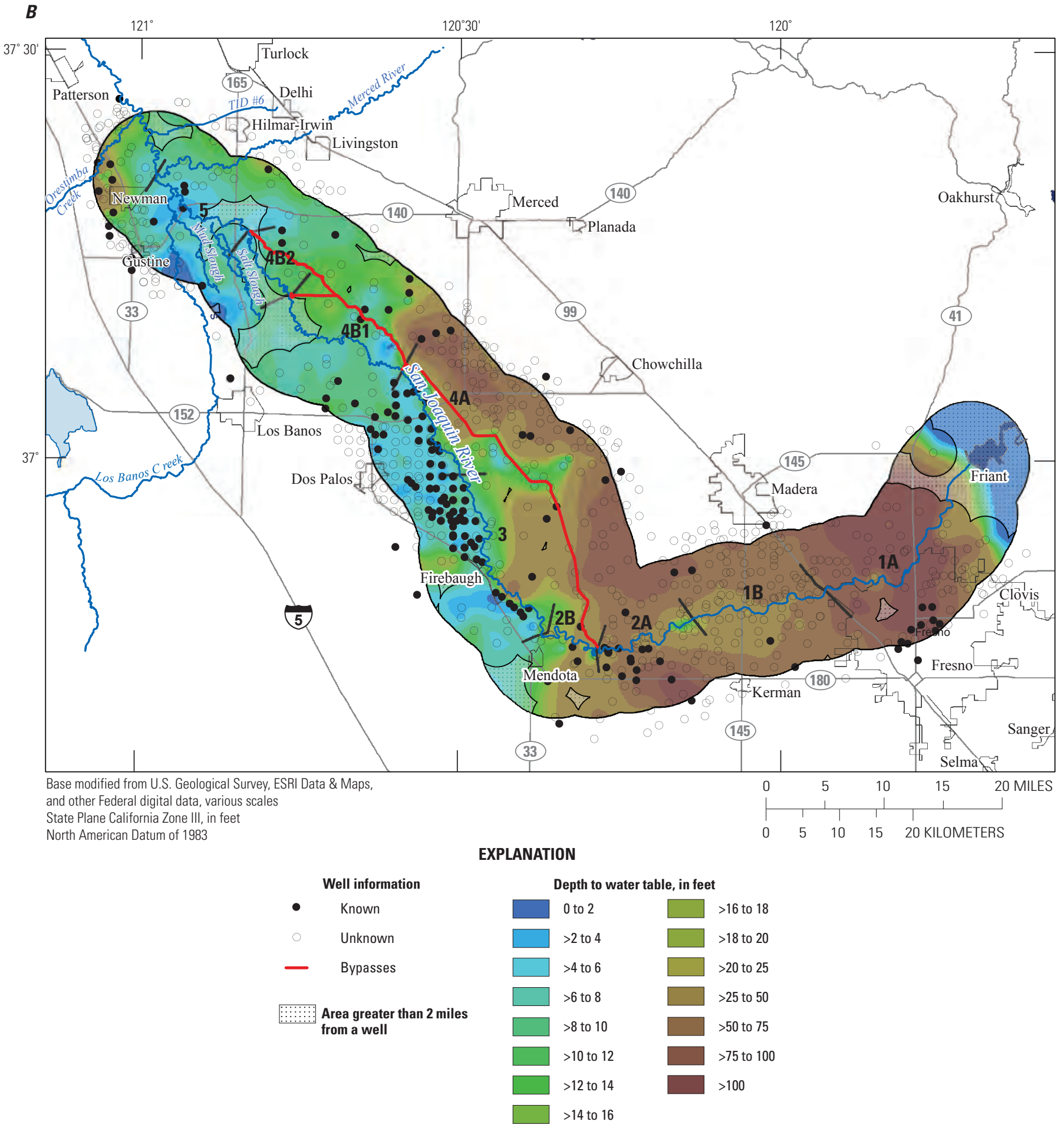

Figure 8. - Continued. 


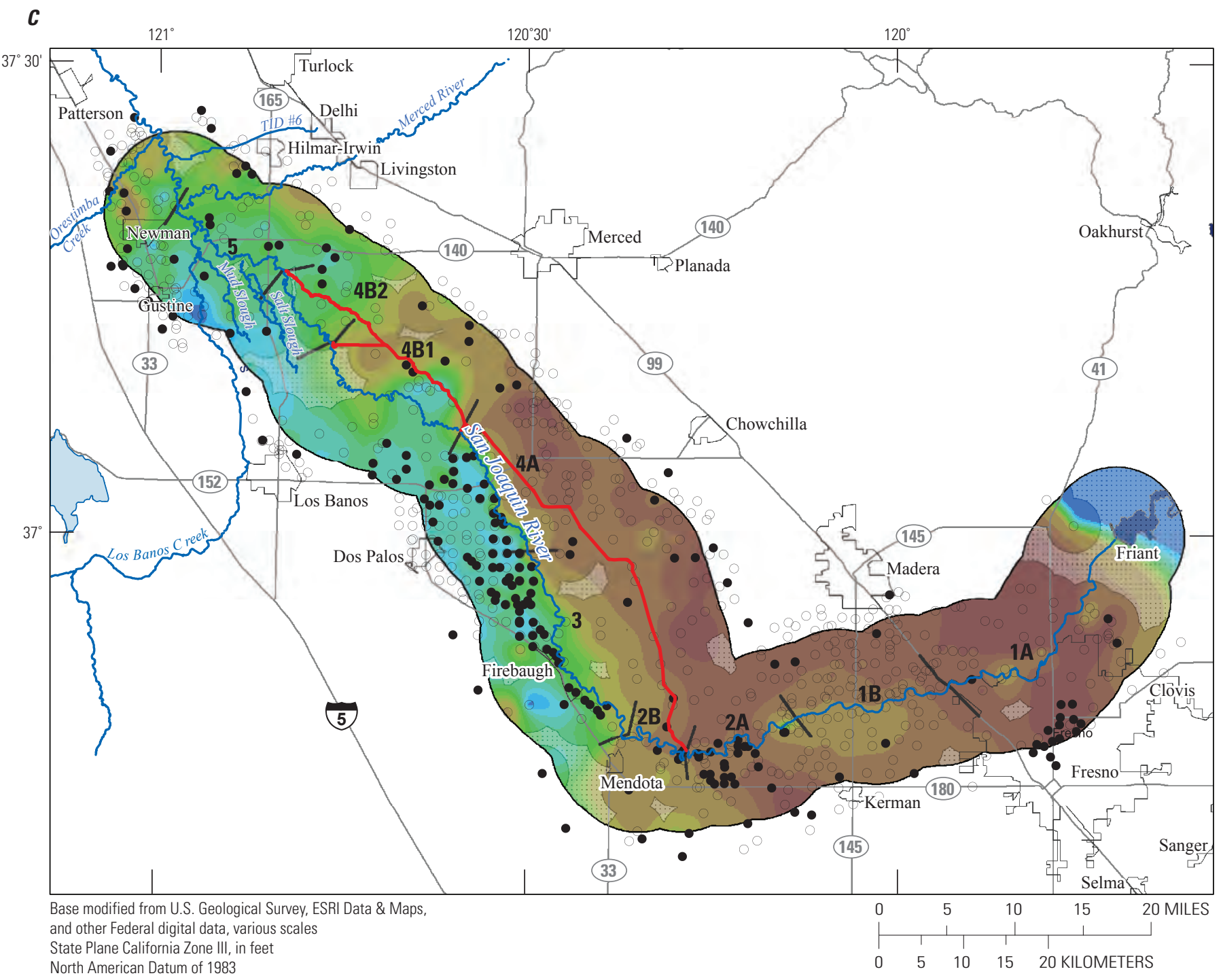

North American Datum of 1983

\section{EXPLANATION}

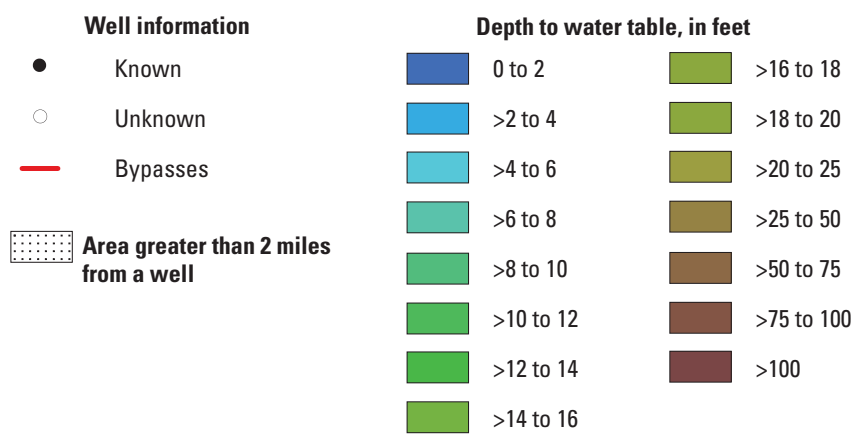

Figure 8. -Continued. 


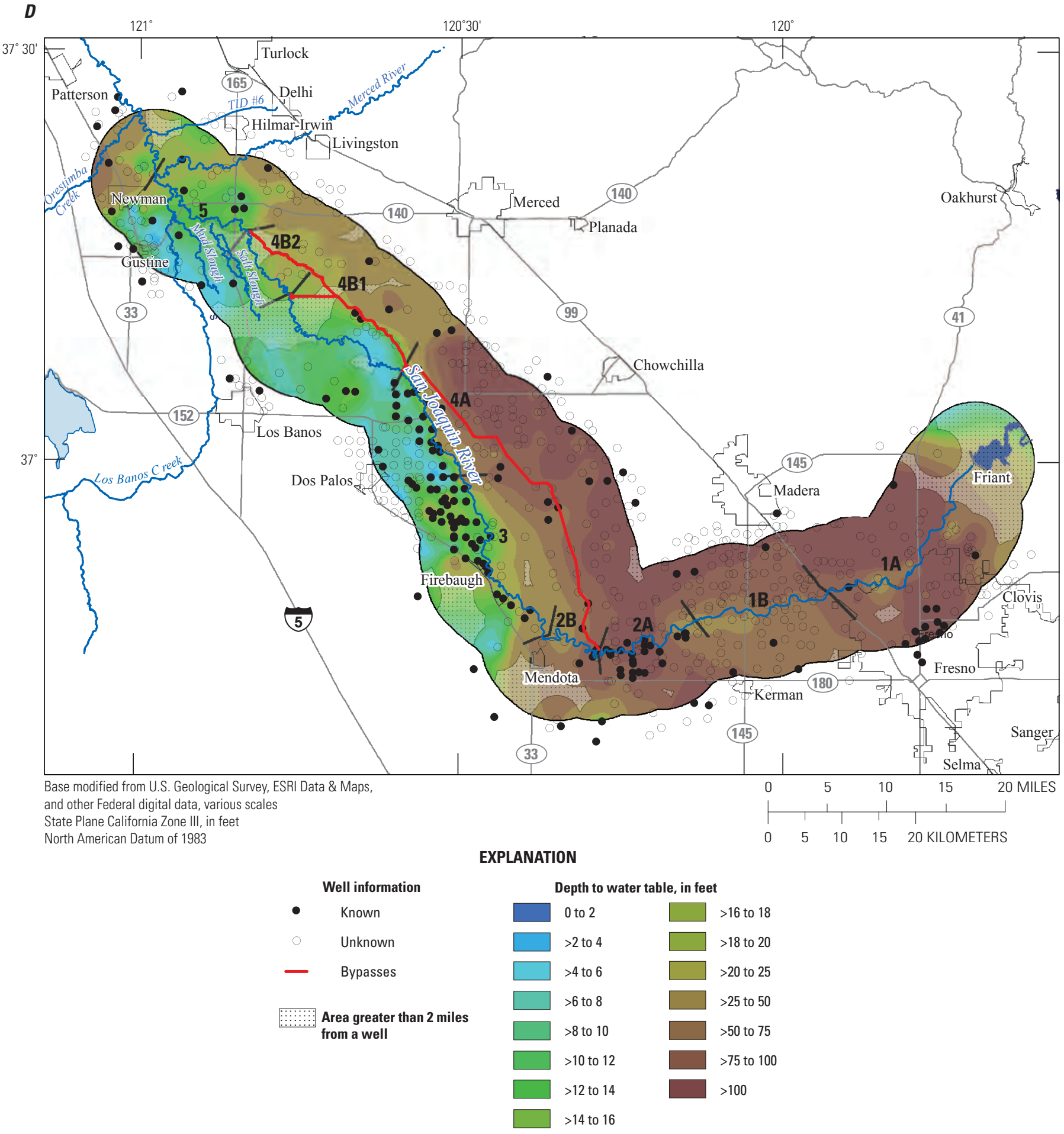

Figure 8. - Continued. 


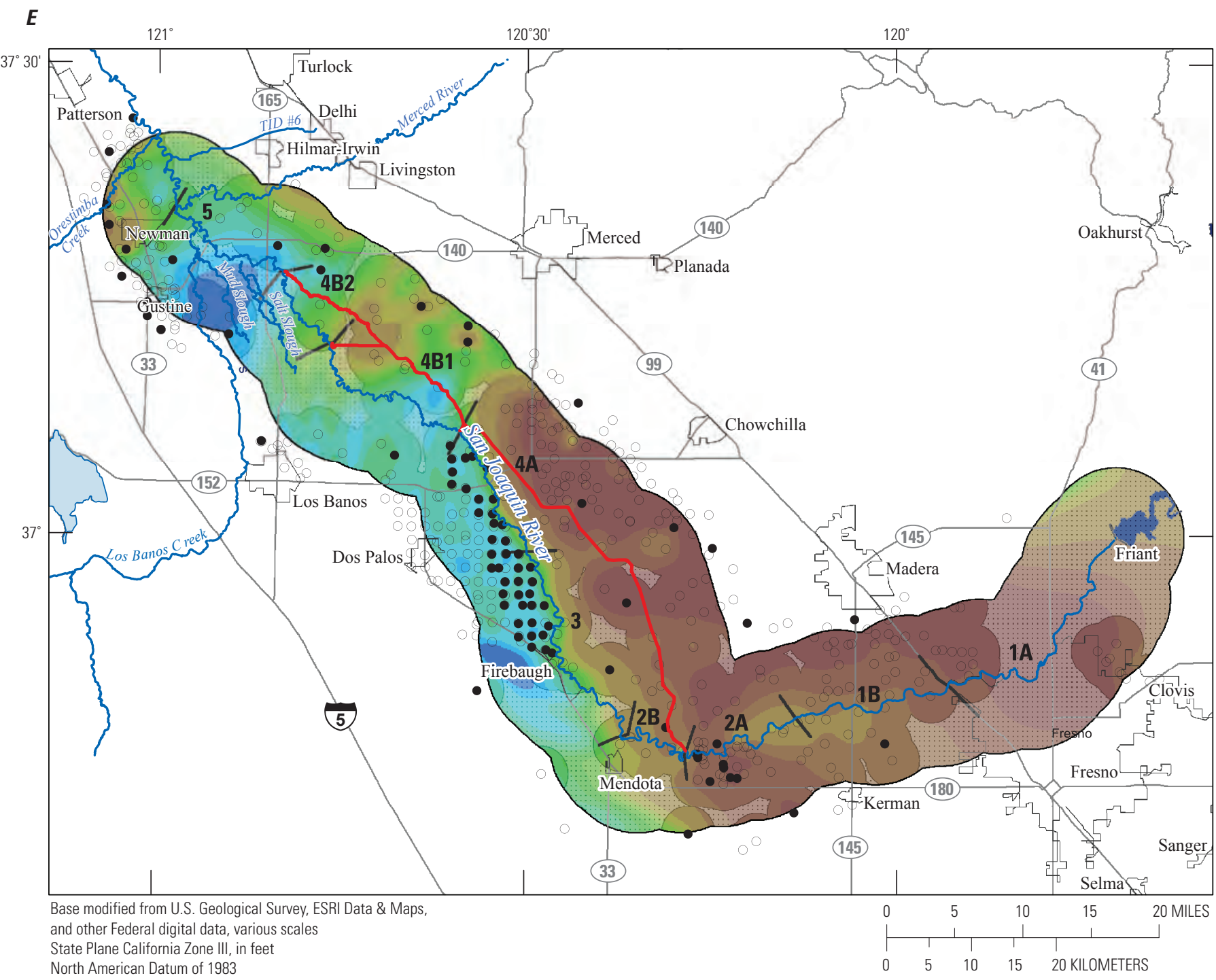

North American Datum of 1983

\section{EXPLANATION}

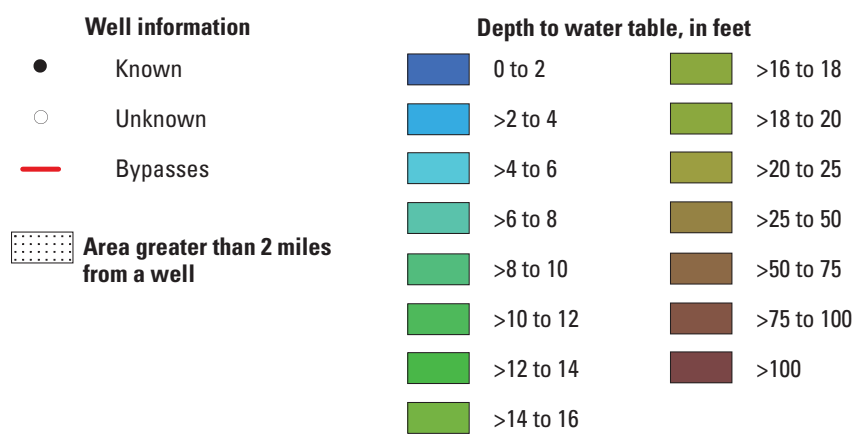

Figure 8. - Continued. 
Between 1988 and 1992, the drought continued-all water-year types were Normal-Dry or Dry. Data from 1991, the fifth year of a 6-year drought, show a change in water levels in response to the combination of reduced availability of surface water, increased groundwater pumping, and reduced recharge from precipitation. By 1991, water levels had declined substantially along the eastern margin of the study area, and the areas of shallow groundwater had retreated compared to those prior to the drought (fig. $8 D$ ).

A Wet year in 2006 was preceded by several Normal-Wet and Normal-Dry years. Although water levels along the eastern margin had remained low, the shallow groundwater areas west of the river and east of the river to the north were fully reestablished (fig. 8E).

This brief historical review shows that shallow groundwater areas, particularly west of the San Joaquin River and east of the river along Reaches 4 and 5, have persisted through time with the exception of during drought conditions. Persistent shallow groundwater areas shown to be within the hydraulic influence of the San Joaquin River potentially are vulnerable to seepage effects from restoration flows.

The historic response of shallow groundwater areas to drought and other dry climatic conditions indicates the shallow water table is sensitive to reduced surface-water availability and associated groundwater pumping on both sides of the river, which is consistent with previous findings by Belitz and Phillips (1995) and K.D. Schmidt and Associates (McBain and Trush, Inc., 2002, p. 4-26). This has implications for year-toyear operations of the SJRRP and for groundwater pumping as a potential future response action.

\section{Interaction of Surface Water and Groundwater}

Prior to development, gaining conditions existed along the San Joaquin River from approximately Reach 2B to Reach 5 (McBain and Trush, Inc., 2002). Between predevelopment and 1961, the water table in the study area substantially declined, by up to $80 \mathrm{ft}$ in some areas, because of regional groundwater pumping. This pumping changed the predevelopment direction of groundwater flow from toward the San Joaquin River to away from the river toward pumping locations. This changed the San Joaquin River from a gaining stream to a losing stream in many parts of the study area (McBain and Trush, Inc., 2002).

Several previous studies estimated the San Joaquin River gains (or losses) from (or to) the groundwater system in the study area (McBain and Trush, Inc., 2002). Other sources documenting estimates of seepage from the San Joaquin River include expert testimony (Deverel, 2005). Comparison of flow rates in the river between streamgages during the interim flow releases for the SJRRP (http://www.restoresjr.net) flows/SurfaceWater/index.html) gives an estimate of seepage between each streamgage.

On the basis of available information, estimates of Reach 1 river losses range from 105 to 250 cubic feet per second $\left(\mathrm{ft}^{3} / \mathrm{s}\right)$; those for Reach 2 range from 75 to $170 \mathrm{ft}^{3} / \mathrm{s}$. Reach 3 is typically a losing reach, whereas Reaches 4 and 5 are typically gaining reaches; however, in these reaches, there can be a net river loss or gain depending on the local and regional hydraulic gradients. Near fields with surface-water irrigation, there is typically a net river gain from groundwater during the growing season. In contrast, near fields with groundwater pumping, there is typically a net river loss to groundwater during the growing season. Data collected during interim flow releases in 2009 showed net seepage losses increased during higher flows compared to lower flows, which is to be expected. The data also showed net seepage losses were greatest during the beginning of increased flows and diminished over time.

\section{Land-Surface Data}

Land-surface processes can have a substantial effect on the hydrologic conditions near the San Joaquin River. Most notably, agriculture that relies on groundwater for irrigation purposes can have a large influence on the lowering groundwater levels in the study area. Conversely, agriculture that relies on surface water for irrigation purposes can have a large influence on the raising groundwater levels in the study area. The datasets discussed in the following sections, including ground-surface elevation, soils, land-use, and water supply and demand, are important for understanding these potential effects.

\section{Ground-Surface Elevation}

The elevation of the ground surface in the study area ranges from about $50 \mathrm{ft}$ along the northernmost part of the San Joaquin River to more than 1,000 ft at the eastern extent of the study area (fig. 9). Ground-surface elevation data were obtained from the USGS National Elevation Dataset (Gesch and others, 2009).

\section{Soils}

The soil data utilized in the study area (and the CVHM) were obtained from the State Soil Geographic Database STATSGO (U.S. Department of Agriculture, Natural Resource Conservation Service, 2005). Two soil types are present within the study area - silty clay and sandy loam; the former is the dominant type (fig. 10).

\section{Land-Use and Crop Data}

The study area is predominantly an agricultural area; in 2000, 66 percent of the land use in the study area was agriculture, 28 percent was native vegetation, and 6 percent was urban. Major crop types grown in the study area include cotton, vineyards, pasture, orchards, and field crops. 


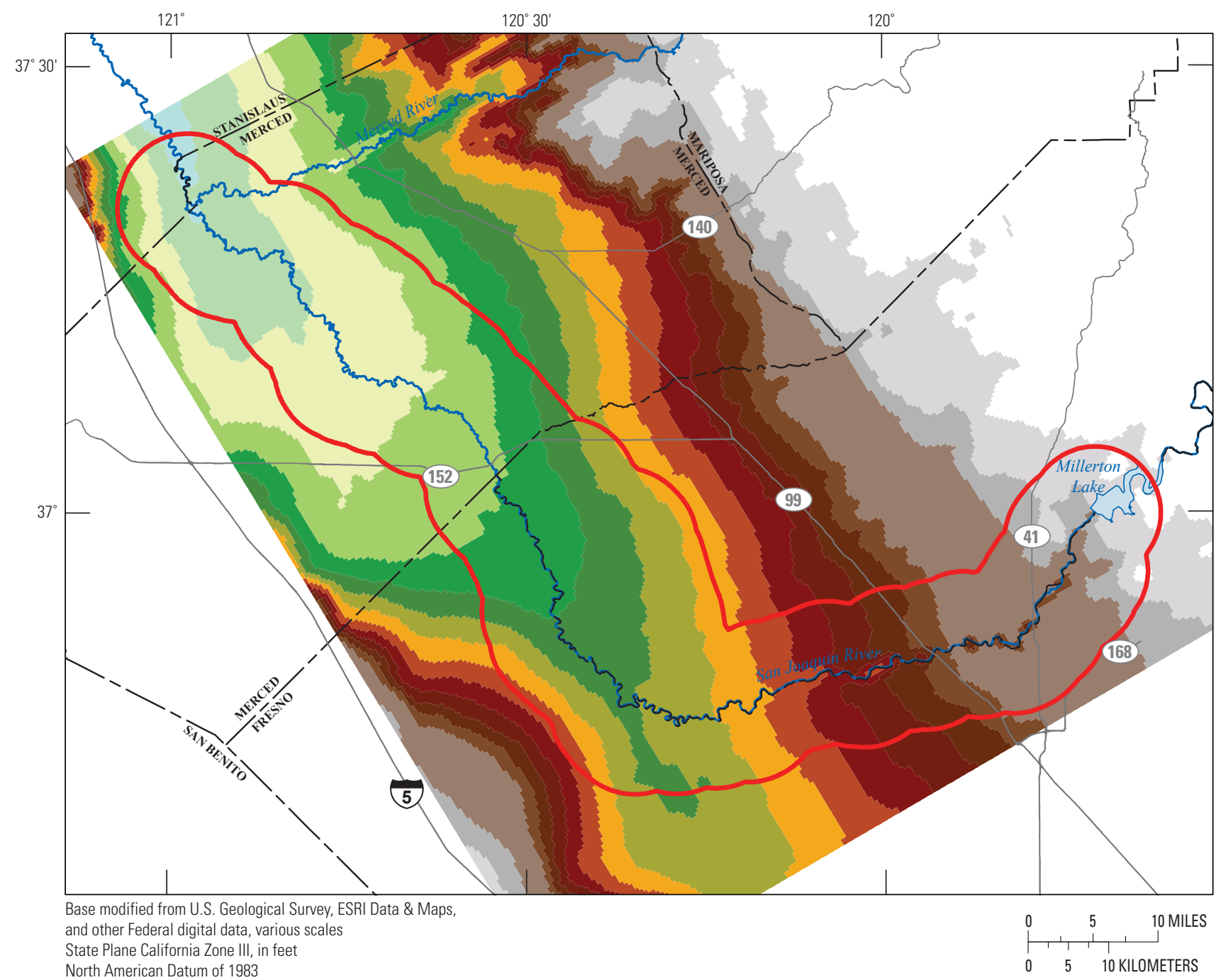

EXPLANATION

\begin{tabular}{|c|c|c|c|}
\hline \multicolumn{2}{|c|}{ Ground-surface elevation, in feet } & & Study area \\
\hline 47 to 60 & 181 to 200 & 401 to 500 & Maior river \\
\hline 61 to 80 & 201 to 220 & 501 to 1,000 & Road \\
\hline 81 to 100 & 221 to 240 & $>1,000$ & County boundary \\
\hline 101 to 120 & 241 to 260 & & \\
\hline 121 to 140 & 261 to 280 & & \\
\hline 141 to 160 & 281 to 300 & & \\
\hline 161 to 180 & 301 to 400 & & \\
\hline
\end{tabular}

Figure 9. Ground-surface elevation in the study area, San Joaquin Valley, California. 


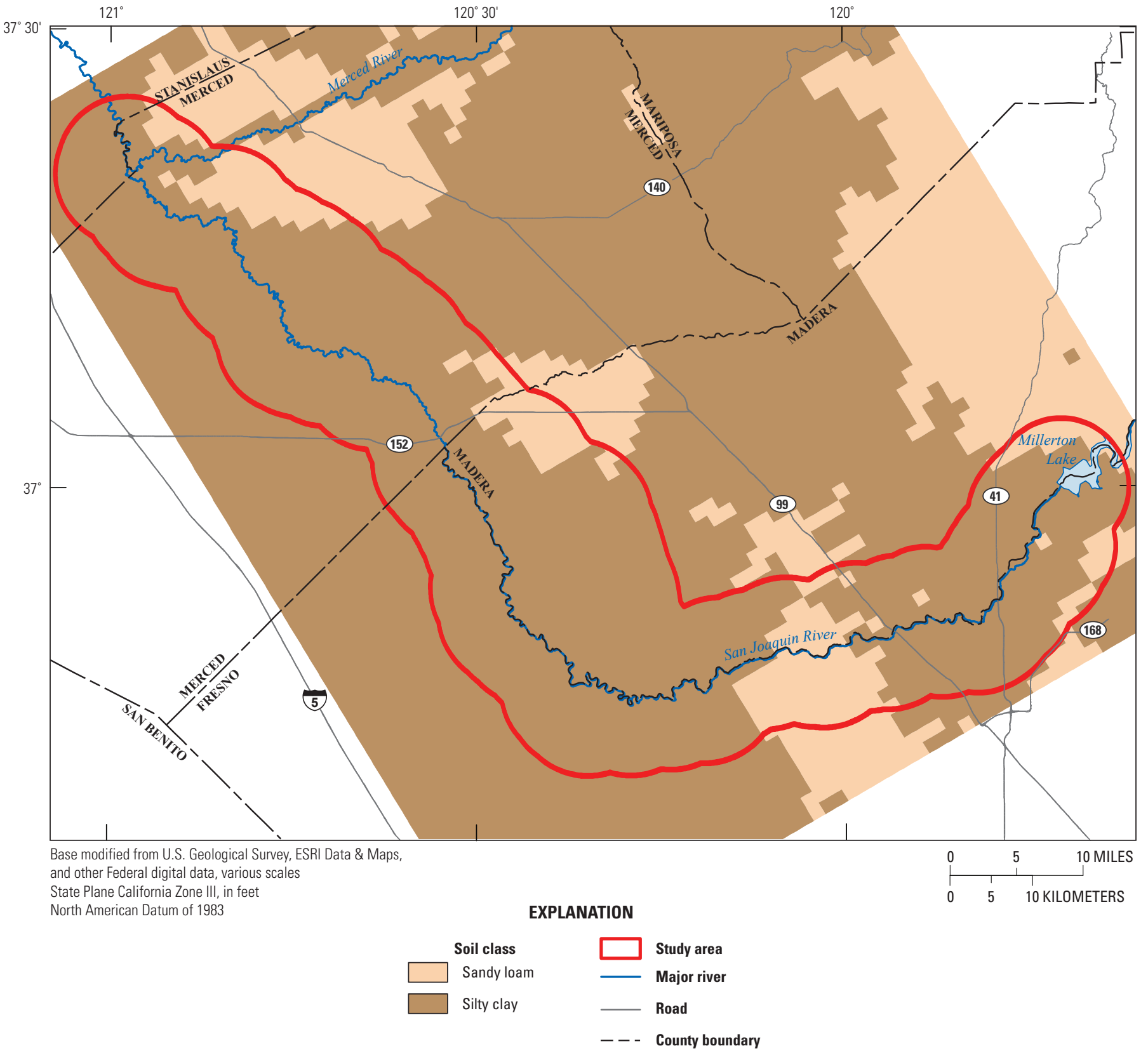

Figure 10. Soil classifications in the study area, San Joaquin Valley, California. 
Table 4. Land-use data available for the study area, San Joaquin Valley, California.

[Abbreviations: CSU, California State University; CVHM, Central Valley Hydrologic Model; DWR, Department of Water Resources; mm/yyyy, month/year; USGS, U.S. Geological Survey]

\begin{tabular}{|c|c|c|c|c|}
\hline Land-use data source & Data provider & Coverages used & $\begin{array}{l}\text { Dates used } \\
\text { to represent } \\
\text { (mm/yyyy) }\end{array}$ & $\begin{array}{l}\text { Same } \\
\text { dataset in } \\
\text { CVHM }\end{array}$ \\
\hline $\begin{array}{l}\text { Central Valley Historic Vegetation Mapping } \\
\text { Project (CVHVMP) }\end{array}$ & CSU Chico & 1960 & $04 / 1961-03 / 1968$ & Yes \\
\hline $\begin{array}{l}\text { Geographic Information Retrieval and Analysis } \\
\text { System (GIRAS) }\end{array}$ & USGS & 1973 & $04 / 1968-03 / 1978$ & Yes \\
\hline County land-use surveys & California DWR & $\begin{array}{l}\text { Fresno County 2000, Madera } \\
\text { County 2001, Merced County 2002, } \\
\text { Stanislaus County } 2004\end{array}$ & 04/1999-10/2003 & No \\
\hline
\end{tabular}

The source of recent land-use data (mid-1990s and later) was from DWR land-use surveys (California Department of Water Resources, 2011b). Historic land-use surveys were obtained from various sources discussed in following paragraphs; these are the same datasets used in the CVHM (table 4).

The study area includes four counties: Fresno, Madera, Merced, and Stanislaus. The DWR conducts land-use surveys by county approximately every 7 years, and the survey dates for each of these counties commonly differ. Two composite land-use coverages were developed for the study area from the available land-use surveys. One composite coverage (referred to as the 1995 coverage) combines the 1994 Fresno County, 1995 Madera County, 1995 Merced County, and 1996 Stanislaus County surveys. The other composite coverage (referred to as the 2000 coverage) combines the 2000 Fresno County, 2001 Madera County, 2002 Merced County, and 2004 Stanislaus County surveys. The 1995 coverage was assumed to represent the period April 1993 through March 1999, and the 2000 coverage represented the period April 1999 through October 2003.

Three coverages were used to represent the period before April 1993. For April 1961 through March 1968, a land-use coverage derived from a patchwork of sources developed by California State University Chico (2003) was used. For April 1968 through March 1978, Anderson level II classifications from the Geographic Information Retrieval and Analysis System (GIRAS) were used (U.S. Geologic Survey, 1990). For April 1978 through March 1993, North American Land Class Data (NLCD) were used (U.S. Geologic Survey, 1999). These three coverages also were used in the CVHM and are described in that report in detail (Faunt, 2009).

The DWR land-use surveys contain more than 80 different land-use/crop types, hereafter referred to as "crop types." For this study, 15 specific crop types were used (table 5). These crop types are based on the DWR "class" symbol, which is the minimum breakdown of land use provided in
Table 5. Crop types in the study area, San Joaquin Valley, California.

[Abbreviations: DWR, Department of Water Resources; N/A, not available]

\begin{tabular}{|c|c|c|}
\hline $\begin{array}{c}\text { Crop } \\
\text { identification } \\
\text { number }\end{array}$ & $\begin{array}{c}\text { Specific } \\
\text { land-use/crop } \\
\text { types }\end{array}$ & $\begin{array}{l}\text { DWR } \\
\text { class } \\
\text { symbol }\end{array}$ \\
\hline 1 & Water & NW \\
\hline 2 & Urban & U, UR, UC, UI, UL, UV \\
\hline 23 & $\begin{array}{l}\text { Irrigated native } \\
\text { vegetation }\end{array}$ & $\mathrm{NV}, \mathrm{NR}, \mathrm{NB}$ \\
\hline 3 & $\begin{array}{l}\text { Non-irrigated native } \\
\text { vegetation }\end{array}$ & NV, NR, NB \\
\hline 8 & Idle & I \\
\hline 9 & $\begin{array}{l}\text { Truck, nursery, and } \\
\text { berry crops (Truck) }\end{array}$ & $\mathrm{T}$ \\
\hline 10 & $\begin{array}{l}\text { Citrus and subtropical } \\
\text { (Citrus) }\end{array}$ & $\mathrm{C}$ \\
\hline 11 & Field & $\mathrm{F}$ \\
\hline 18 & Cotton & F-subclass 1 \\
\hline 12 & Vineyards & V \\
\hline 13 & Pasture & $\mathrm{P}$ \\
\hline 14 & $\begin{array}{l}\text { Grain and hay crops } \\
\text { (Grain) }\end{array}$ & G \\
\hline 15 & $\begin{array}{l}\text { Semiagricultural and in- } \\
\text { cidental to agriculture } \\
\text { (Dairies) }\end{array}$ & $\mathrm{S}$ \\
\hline 16 & $\begin{array}{l}\text { Deciduous fruits and } \\
\text { nuts (Orchards) }\end{array}$ & $\mathrm{D}$ \\
\hline 17 & Rice & $\mathrm{R}$ \\
\hline \multicolumn{3}{|c|}{ General land-use/crop types } \\
\hline 4 & $\begin{array}{l}\text { Orchard, groves, and } \\
\text { vineyards }\end{array}$ & N/A \\
\hline 5 & Pasture and hay & N/A \\
\hline 6 & Row crops & $\mathrm{N} / \mathrm{A}$ \\
\hline 7 & Small grains & $\mathrm{N} / \mathrm{A}$ \\
\hline 19 & Developed & N/A \\
\hline 20 & Cropland and pasture & N/A \\
\hline
\end{tabular}


their surveys. Cotton, which is a subclass of field crops, was separated into its own crop type because it is widespread in the study area, and it typically has different water-use characteristics than other field crops. Native vegetation was also separated into irrigated native vegetation (to represent irrigated wildlife management areas) and non-irrigated native vegetation.

In addition to these 15 specific crops types, 6 general crop-type categories were utilized to accommodate the more historic land-use surveys, which have less detailed crop categories than the DWR surveys (table 5).

Five crop-distribution maps were used in this study (fig. 11A-E). The crop distributions for the historic periods were aggregated at 1 -mi resolution, consistent with the CVHM grid. Those for the two most recent periods were aggregated at 0.25 -mi resolution.

\section{Crop-Related Data}

This section briefly defines and describes the crop-related data used in this study; more detailed definitions are provided in Schmid and Hanson (2009). Values for crop-related datasets are provided by the CVHM and are documented in appendix A. Crop coefficients and irrigation efficiencies were adjusted during model calibration.

Crop-related data include the following:

- Root-zone depths.

- Root-uptake coefficients (negative hydrostatic-pressure heads for optimal growth, anoxia, and wilting point).

- Crop coefficients.

- Fractions of transpiration and evaporation.

- Fractions of direct runoff for precipitation.

- Fractions of direct runoff for irrigation.

- Irrigation efficiencies.

Root-zone depths are defined for each crop type and are important for calculating the groundwater uptake by crops. Root-uptake coefficients represent, for each crop type, the relative hydrostatic pressure at which anoxia, optimal growth, and wilting occur. Crops such as rice have a relative hydrostatic pressure greater than zero for anoxia because they grow even when the fields are flooded. Most crops will experience anoxia if the roots are inundated for an extended period. Wilting occurs if the water content in the root zone is too low to sustain the crop for an extended period.

A crop coefficient is the ratio of the actual evapotranspiration (ET) for a crop to the reference evapotranspiration ( $\mathrm{ET}_{\mathrm{o}}$ ) and is used as a scaling factor for calculating actual ET from $\mathrm{ET}_{\mathrm{o}}$. Crop coefficients are defined for each crop type and vary monthly on the basis of the growth stage of the crop.
The fractions of transpiration and evaporation vary linearly with the amount of field area covered by each crop type and sum to 1.0. These fractions vary monthly on the basis of the growth stage of the crop. For example, a bare field will have a fraction of transpiration (Ftr) of 0.0 and a fraction of evaporation of precipitation (Fep) of 1.0. In contrast, a field with a crop canopy covering the entire field will have an Ftr of 1.0 and an Fep of 0.0. The fraction of evaporation of irrigation (Fei) is the portion of the field not covered by the crop canopy that has irrigation water flowing on it (such as an irrigation furrow); it is always less than or equal to Fep (Schmid and Hanson, 2009).

The fraction of direct runoff of precipitation represents the fraction of the total precipitation that runs off directly to the streams and is not available for crop use. Fractions of direct runoff of precipitation are defined for each crop type. The fraction of precipitation available for crop use is equal to 1.0 minus the fraction of direct runoff of precipitation.

The fraction of direct runoff of irrigation represents the fraction of the total irrigation supply (groundwater pumping and surface-water deliveries) that runs off directly to the streams and is not available for crop use. Fractions of direct runoff of irrigation are defined for each crop type. The fraction of irrigation water available for crop use is equal to 1.0 minus the fraction of direct runoff of irrigation.

Irrigation efficiency can be defined in many different ways. For this study, it is defined as the ratio of water utilized (consumptively) by the crop to the water applied to the crop. The fraction of irrigation water that becomes percolation to groundwater is equal to 1.0 minus the irrigation efficiency.

\section{Climate}

The long-term average annual precipitation in the study area, from 1961 to 2003, was 11.4 in., ranging spatially from 7 to 18 in. (fig. 12). The vast majority (89 percent) of the precipitation is during November to April (fig. 13). Monthly spatially varying precipitation estimates for the study area during 1961-2003 were obtained from the ParameterElevation Regressions on Independent Slopes Model (PRISM) (Climate Source, 2006).

Long-term average annual $\mathrm{ET}_{\mathrm{o}}$ in the study area, from 1961 to 2003 , is $53.2 \mathrm{in}$., ranging spatially from 50 to 55 in. (fig. 14). A total of 64 percent of ET occurs during the growing season between May and October (fig. 13). Evapotranspiration exceeds rainfall in all months except December and January, which necessitate irrigation in order to grow most crops in the study area. Monthly spatially

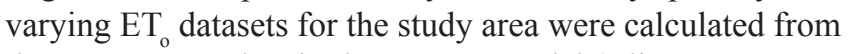
the temperature data in the PRISM model (Climate Source, 2006) using the Hargreaves-Samani equation (Hargreaves and Samani, 1982). 


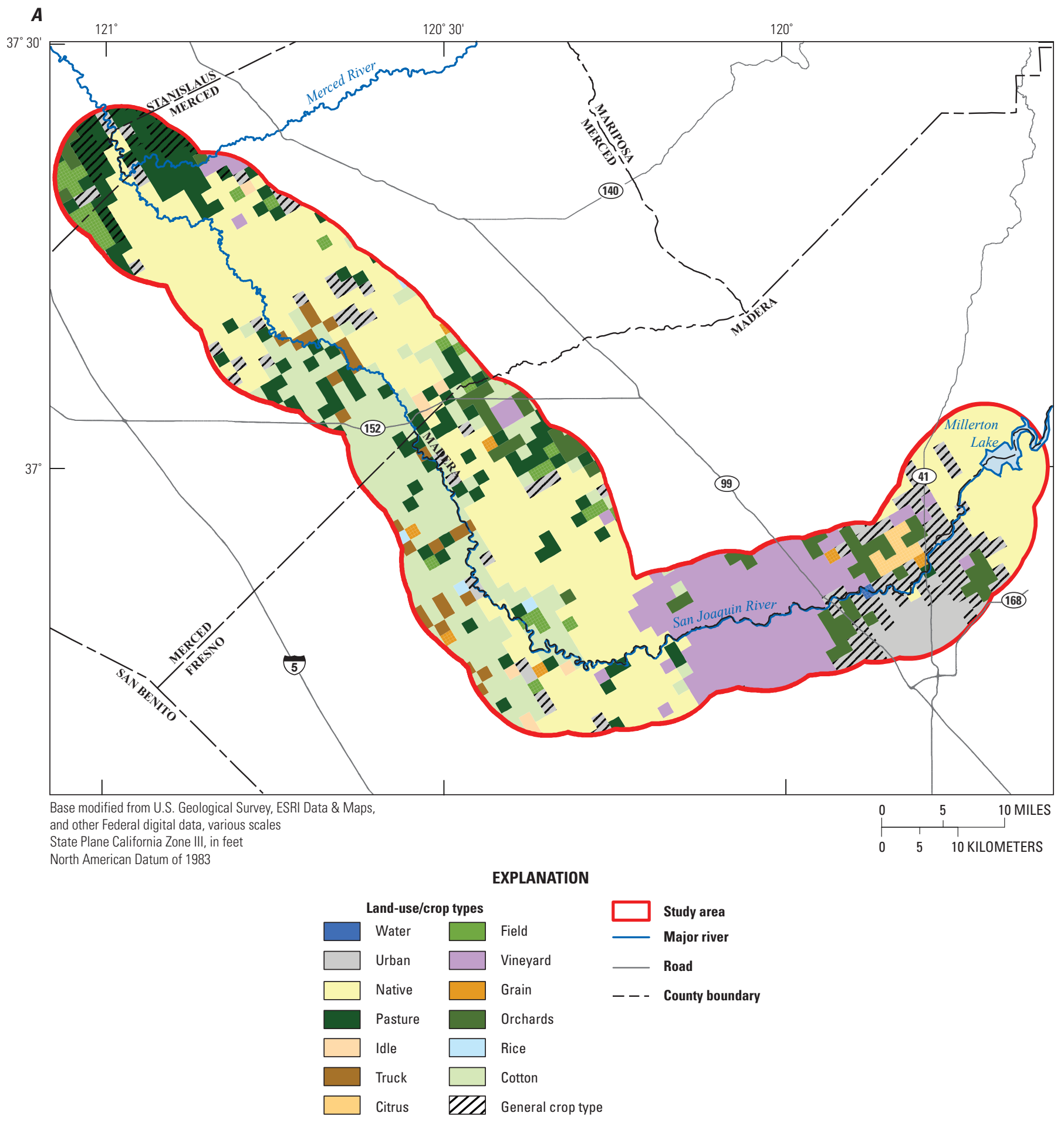

Figure 11. Distribution of crop type in the study area, San Joaquin Valley, California: $A, 1961-68 ; B, 1968-78 ; C, 1978-93 ; D, 1994-99$; E, 1999-2003. 
B

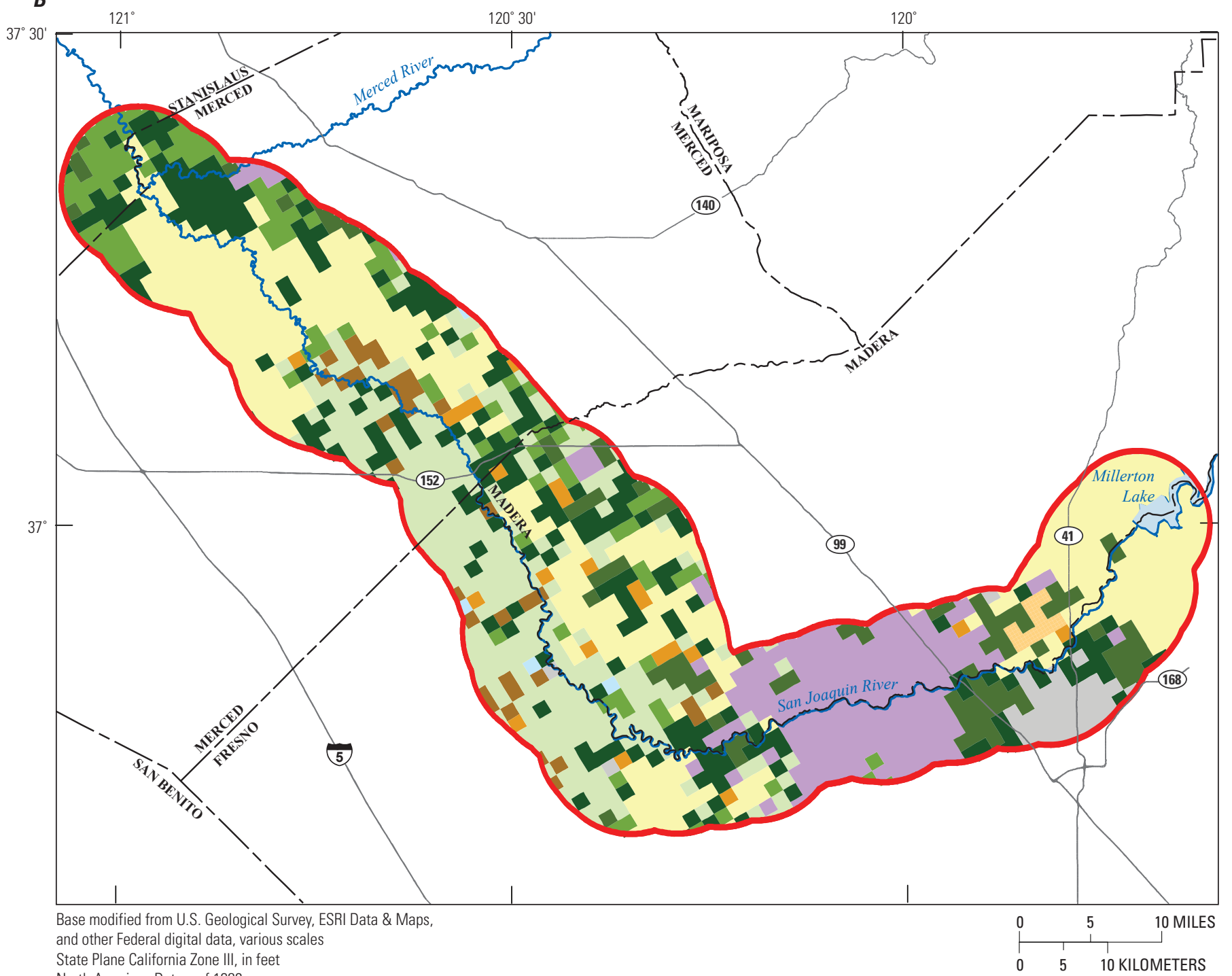

State Plane California Zone III, in feet
North American Datum of 1983

EXPLANATION

\begin{tabular}{|c|c|c|c|}
\hline \multicolumn{3}{|c|}{ Land-use/crop types } & \multirow{2}{*}{$\begin{array}{l}\text { Study area } \\
\text { Major river }\end{array}$} \\
\hline Water & Field & - & \\
\hline Urban & Vineyard & & Road \\
\hline Native & Grain & --- & County boundary \\
\hline Pasture & Orchards & & \\
\hline Idle & Rice & & \\
\hline Truck & Cotton & & \\
\hline Citrus & General c & & \\
\hline
\end{tabular}

Figure 11. - Continued 


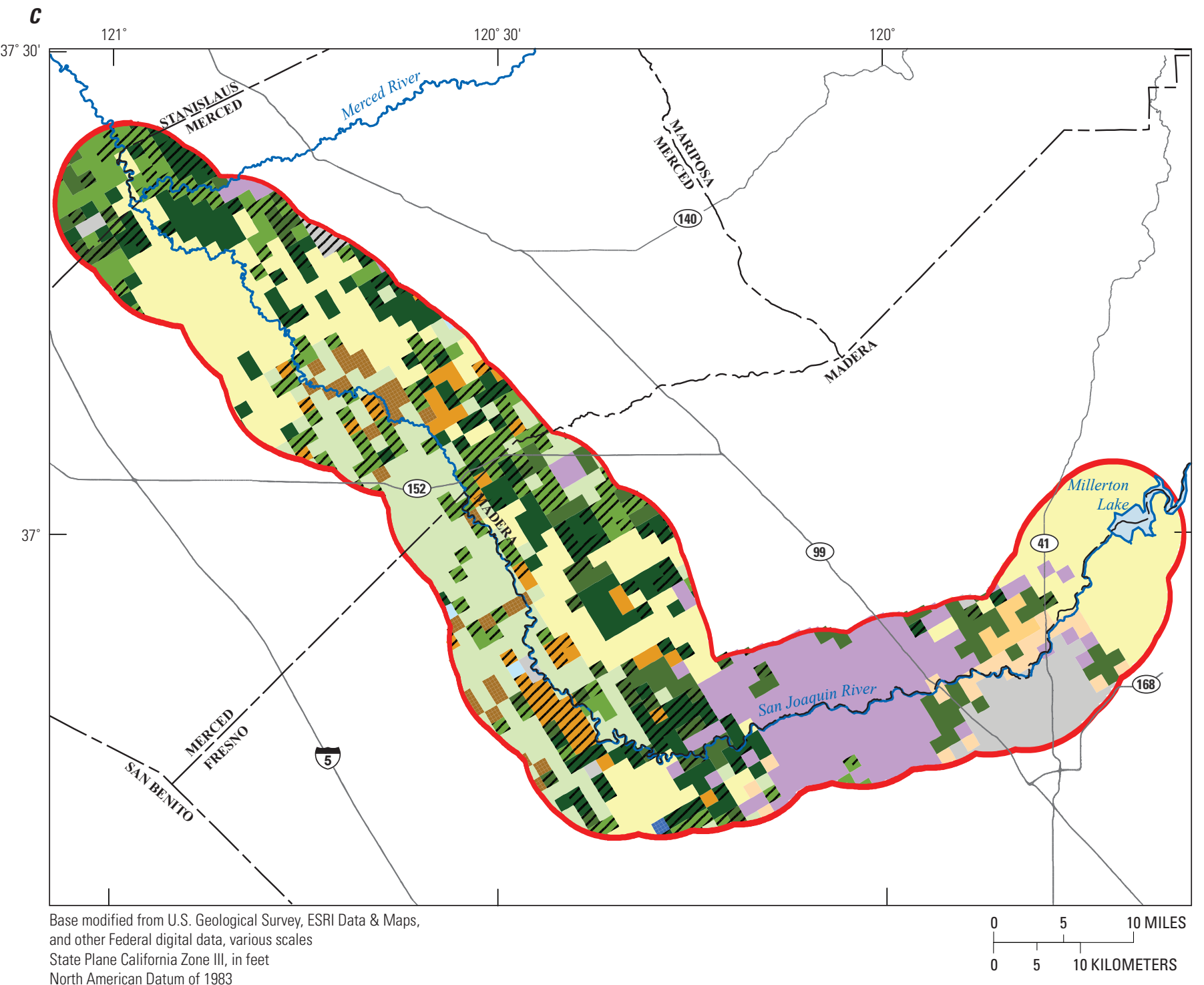

State Plane California Zone III, in feet
North American Datum of 1983

EXPLANATION

\begin{tabular}{|c|c|c|c|}
\hline \multicolumn{2}{|c|}{ Land-use/crop types } & & Study area \\
\hline Water & Field & - & Major river \\
\hline Urban & Vineyard & & Road \\
\hline Native & Grain & --- & County boundary \\
\hline Pasture & Orchards & & \\
\hline Idle & Rice & & \\
\hline Truck & Cotton & & \\
\hline Citrus & General c & & \\
\hline
\end{tabular}

Figure 11. - Continued 


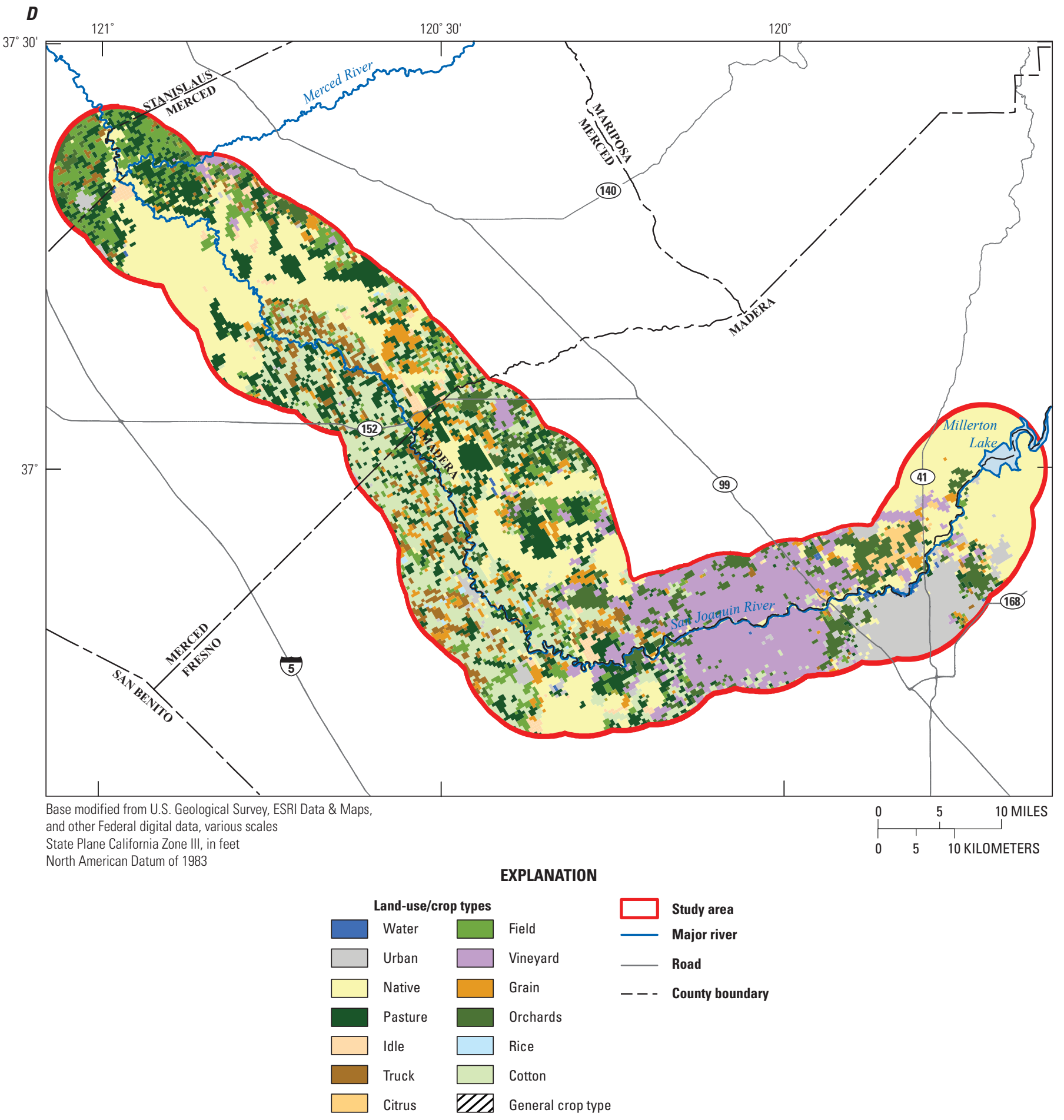

Figure 11. - Continued 


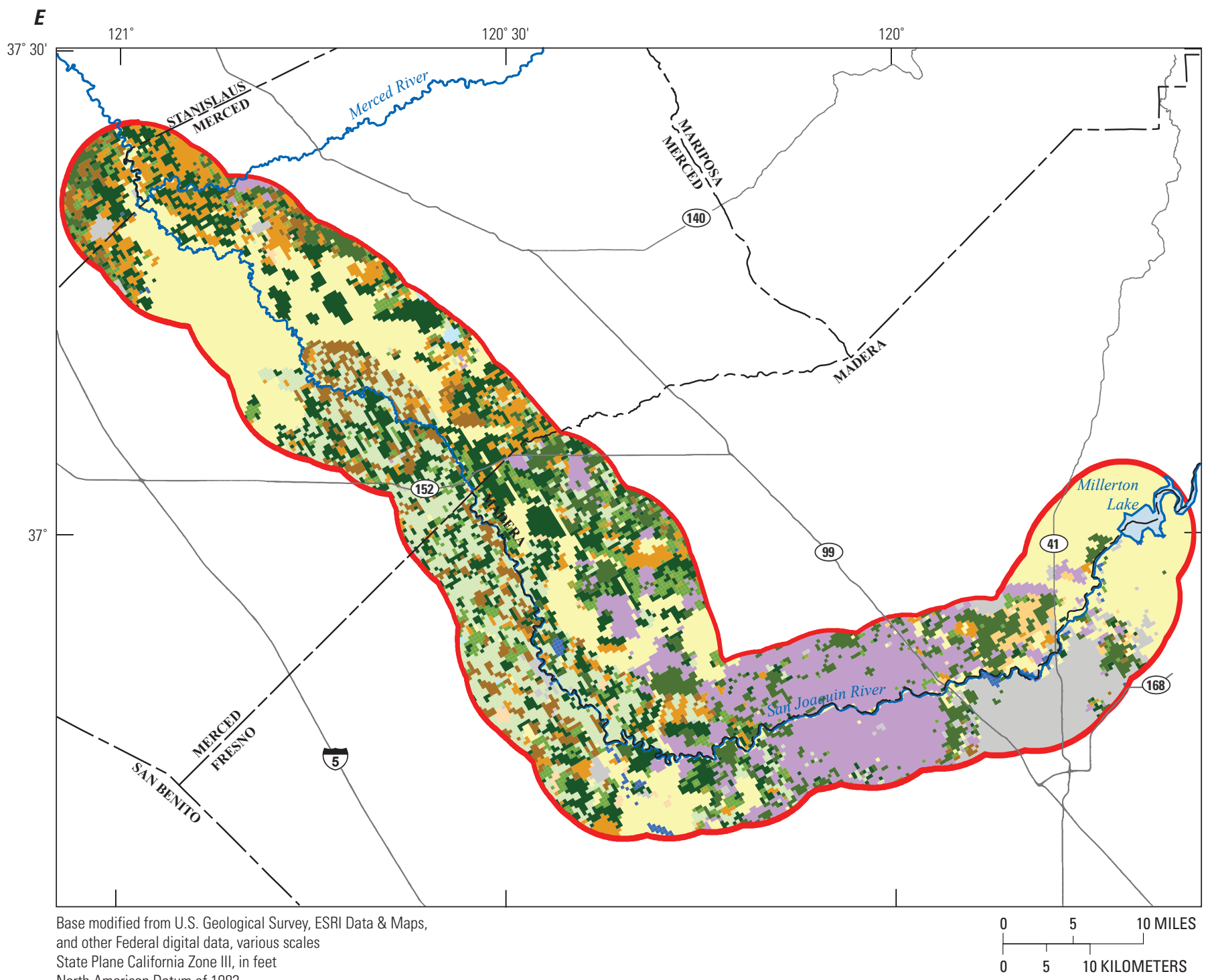

State Plane California Zone III, in feet
North American Datum of 1983

EXPLANATION

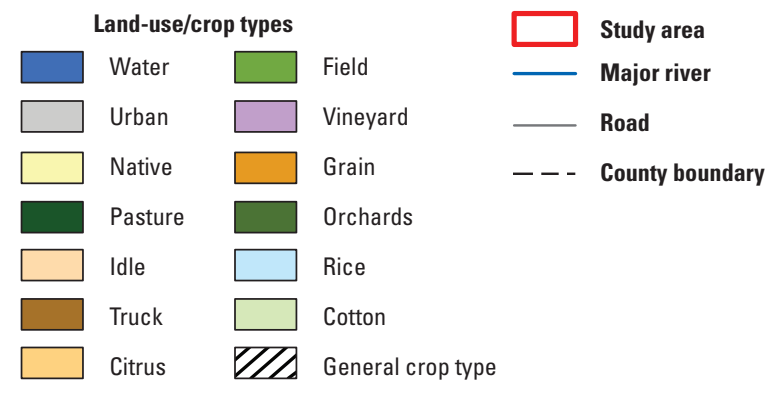

Figure 11. - Continued 


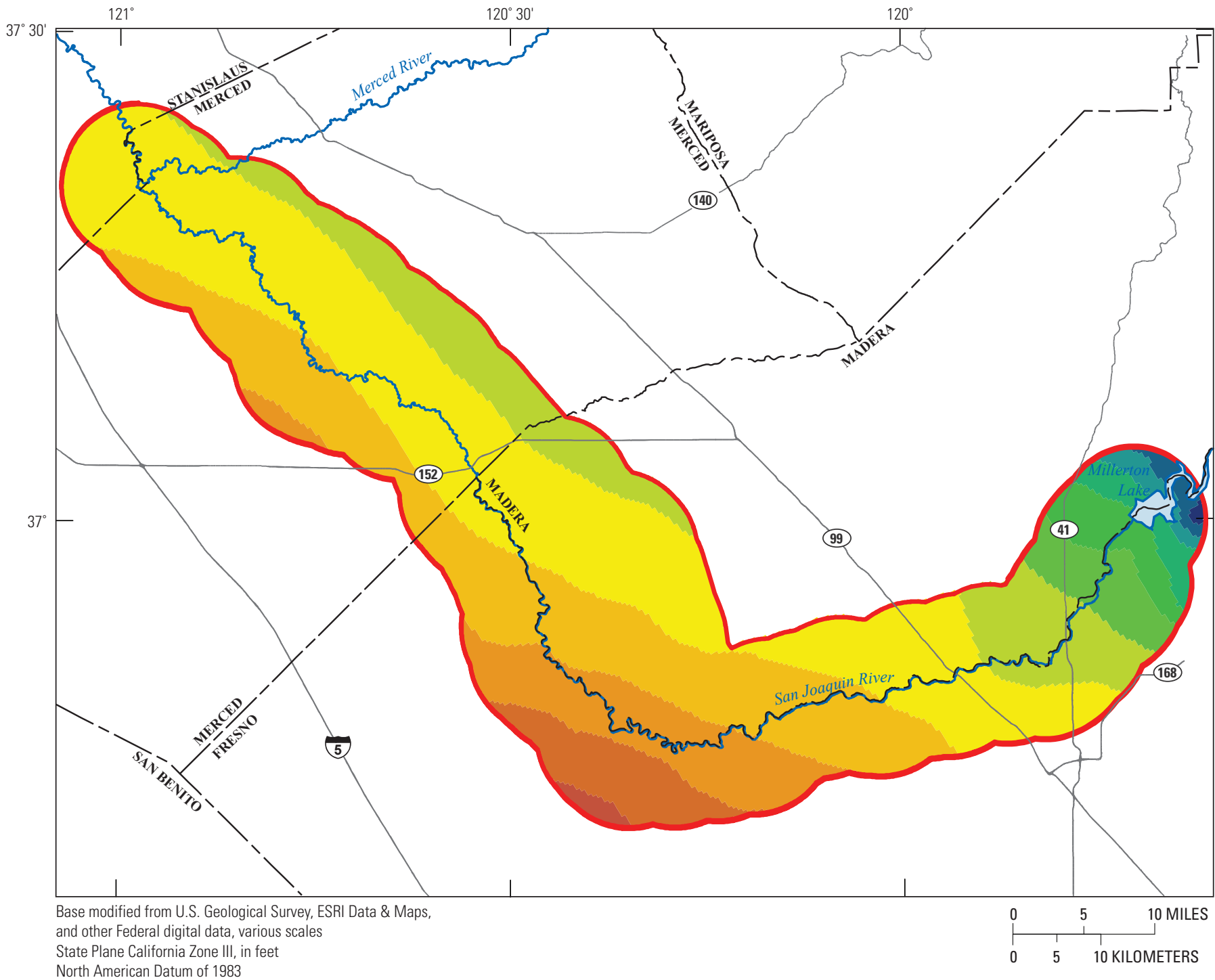

North American Datum of 1983

EXPLANATION

\begin{tabular}{|c|c|c|c|}
\hline \multicolumn{2}{|c|}{$\begin{array}{l}\text { Average annual precipitation, } \\
\text { in inches per year }\end{array}$} & & \multirow{2}{*}{$\begin{array}{l}\text { Study area } \\
\text { Major river }\end{array}$} \\
\hline 7.7 to 8.0 & 13.1 to 14.0 & & \\
\hline 8.1 to 9.0 & 14.1 to 15.0 & & Road \\
\hline 9.1 to 10.0 & 15.1 to 16.0 & --- & County boundary \\
\hline 10.1 to 11.0 & 16.1 to 17.0 & & \\
\hline 11.1 to 12.0 & 17.1 to 18.0 & & \\
\hline 12.1 to 13.0 & 18.1 to 18.3 & & \\
\hline
\end{tabular}

Figure 12. Annual average precipitation in the study area, San Joaquin Valley, California. 


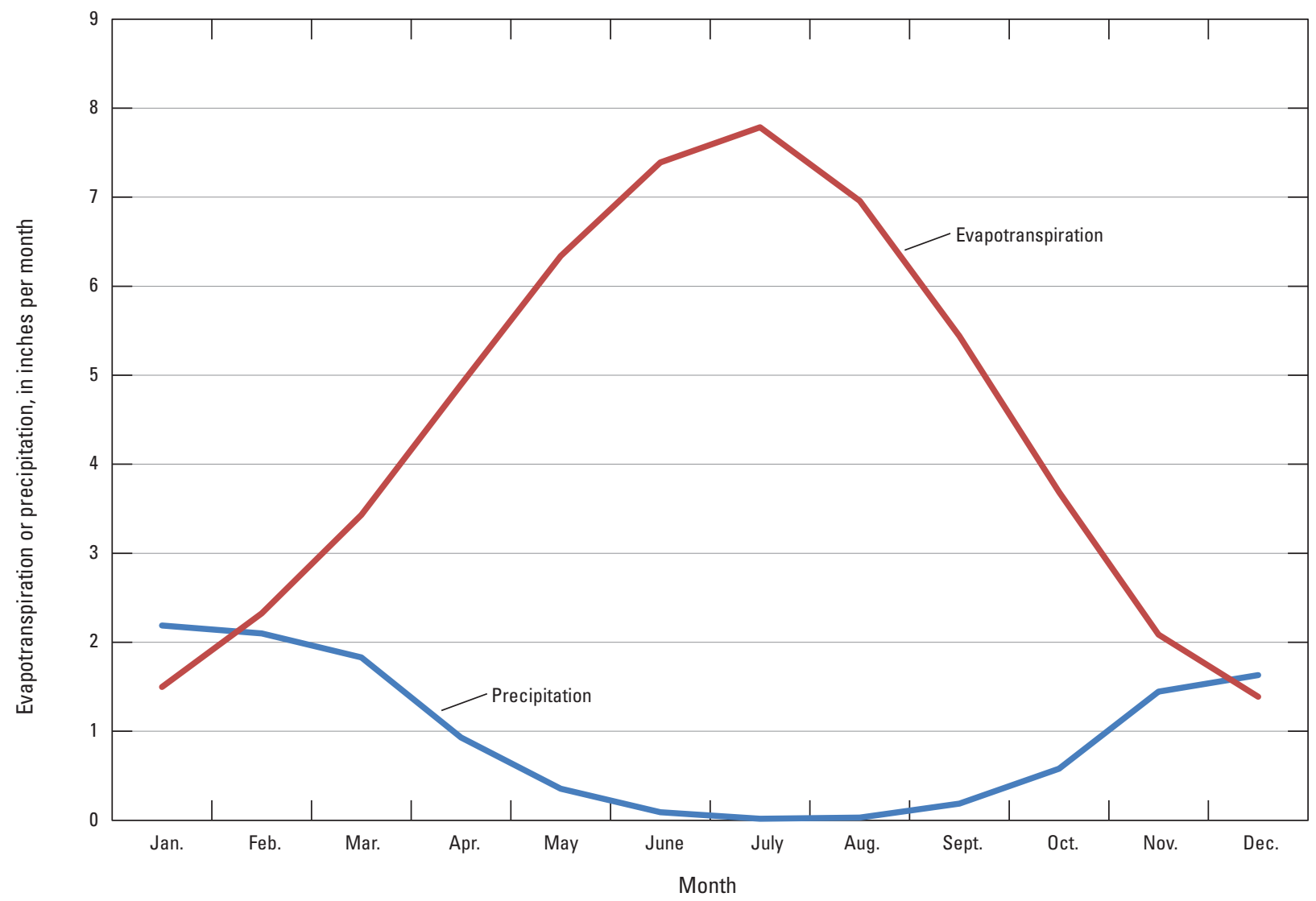

Figure 13. Monthly average precipitation and evapotranspiration (ET $)$ in the study area, San Joaquin Valley, California. 


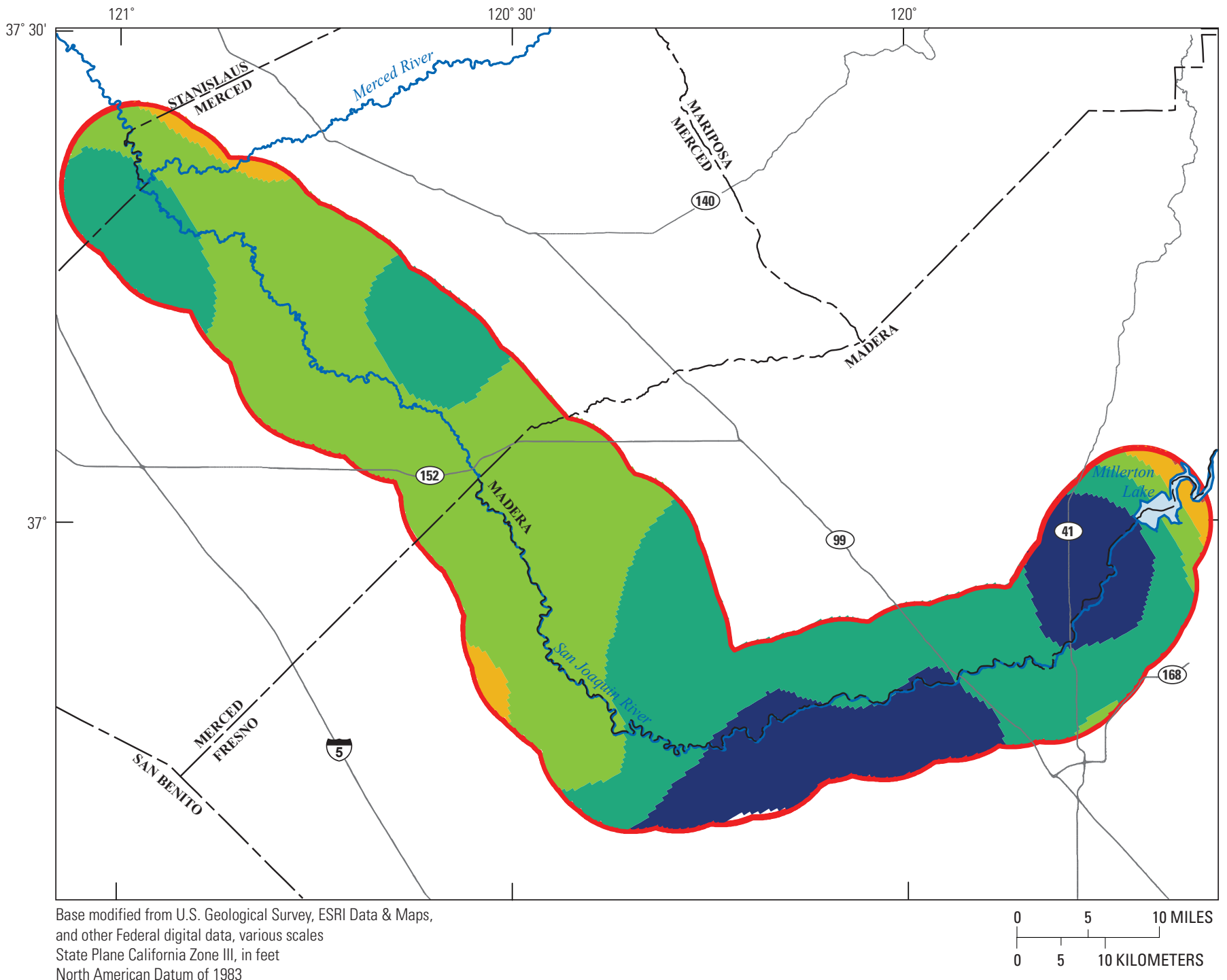

North American Datum of 1983

\section{EXPLANATION}

\begin{tabular}{|c|c|c|}
\hline $\begin{array}{l}\text { Evapotranspiratrion, } \\
\text { in inches per year }\end{array}$ & 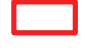 & \\
\hline 50.7 to 51.0 & & \\
\hline 51.1 to 52.0 & & County boundary \\
\hline 52.1 to 53.0 & & \\
\hline 53.1 to 54.0 & & \\
\hline 54.1 to 54.7 & & \\
\hline
\end{tabular}

Figure 14. Annual average evapotranspiration in the study area, San Joaquin Valley, California. 


\section{Water Supply and Demand Data}

Agriculture is the single largest user of water in the study area. Urban areas are small relative to the agricultural area, and their corresponding water use is also small by comparison. The study area also includes several irrigated wildlife management areas. Agriculture in the study area relies on groundwater and surface water for irrigation purposes. The area west of the San Joaquin River irrigates predominantly with surface water, and the area to the east of the San Joaquin River irrigates predominantly with groundwater.

Surface-water deliveries for agriculture are reported by Reclamation and DWR, the Federal and state water providers. Much of the study area west of the San Joaquin River receives surface water through the Federal Central Valley Project (CVP). Monthly deliveries from 1970 to present are well documented by individual water purveyor. CVP delivery records from 1993 to present are available online (U.S. Bureau of Reclamation, Central Valley Operations Office, 2011). CVP delivery records during 1970-92, available in hard-copy format from DWR (California Department of Water Resources, written commun., 2009), were obtained and digitized.

Parts of the study area east of the San Joaquin River receive CVP water via the Madera Canal, for which data are available. Much of the surface water on the east side is derived from local supplies, such as the Kings, San Joaquin, Fresno, and Chowchilla Rivers. Data for deliveries of local surfacewater supplies to individual water purveyors generally are not available. To estimate these deliveries, annual surface-water deliveries for 1998-2005, aggregated by DWR into geographic regions called Detailed Analysis Units (DAUs), were obtained from DWR (Chris Montoya, California Department of Water Resources, written commun., 2011). DWR also compiles monthly surface-water delivery data for larger geographic regions called Planning Areas (PAs), which are composed of multiple DAUs. Monthly surface-water deliveries for these PAs during the entire study period (1961-2003) were obtained from DWR (C. Brush, California Department of Water Resources, written commun., 2007) as part of the CVHM study.

Monthly surface-water deliveries to the city of Fresno, city of Clovis, and Fresno Irrigation District were obtained from the annual Kings River Watermaster Reports (Kings River Water Association, 1961-2003). Monthly surface-water deliveries to Gravelly Ford Water District were obtained from CALSIM records (California Department of Water Resources, 2011a).

The aggregated annual surface-water deliveries to the study area from 1961 to 2003 average 860,000 acre-ft, ranging from 410,000 acre-ft in 1977 , a drought year, to 1,290,000 acre-ft in 1984 (fig. 15). The largest monthly average surface-water deliveries to the study area during 1961-2003 were during the spring-summer growing season, which coincides with the greatest agricultural demand (fig. 16).

\section{Urban and Wildlife Management Areas Water Supply and Demand}

Urban water demand in the study area is driven by municipal water use for the organized communities and by private domestic water use in the rural areas. Municipal water purveyors in the study area include city of Newman, city of Firebaugh, city of Mendota, city of Gustine, city of Dos Palos, Biola Community Services District, community of Bonadelle Ranchos, Pinedale County Water District, city of Fresno, and city of Clovis. Pumping data available for these purveyors (Chris White, Central California Irrigation District, written commun., 2011) were insufficient to develop a complete pumping record for the entire study period. Groundwater pumping for urban water supply was estimated from landuse surveys by assuming an annual pumping rate of 1 acre- $\mathrm{ft}$ per acre. The spatial distribution of urban pumping for April 1999-September 2003, for example, coincides with the urban land use for 2000 (fig. 17). By applying this methodology, the total annual estimated urban pumping during the simulation period was estimated (fig. 18A); this estimate generally was consistent with the available data. The annual pumping was distributed on a monthly basis (fig. 18B) using the monthly distribution of the available data. Rural domestic water use in the study area is supplied though private domestic wells. As with agricultural production wells, little or no data are available for these wells.

The study area contains several wildlife management areas, including North Grasslands Wildlife Areas, Los Banos Wildlife Management Area, San Luis National Wildlife Refuge, and Mendota Wildlife Management Area (fig. 19). These wildlife areas receive surface water though the CVP; data for these deliveries were obtained in the same manner as the CVP agricultural deliveries.

\section{Model Development}

Groundwater flow in the SJRRPGW was simulated using MODFLOW-FMP2 (Schmid and Hanson, 2009), which is based on MODFLOW-2005 (Harbaugh, 2005). The Farm Process (FMP2) was used primarily to simulate the supply and demand components of irrigated agriculture. Agricultural pumping data are not available in the study area, so the FMP2 was especially useful for estimating this large component of the groundwater budget. The FMP2 also simulates percolation (below the root zone) of irrigation water and precipitation, a major component of total recharge in the study area. The Hydrogeologic Unit Flow (HUF) Package (Anderman and Hill, 2000) was used to specify the aquifer properties, including hydraulic conductivity, specific yield, and specific storage. The Streamflow-Routing (SFR2) Package (Niswonger and Prudic, 2005) was used to simulate the streams and bypasses in the model and the interaction between these streams and the groundwater system. The Observations Package (Hill and others, 2000) and the HYDMOD Package (Hanson and Leake, 1999) were used to process model results. The MODFLOW packages and processes used in the SJRRPGW are summarized in table 6. 


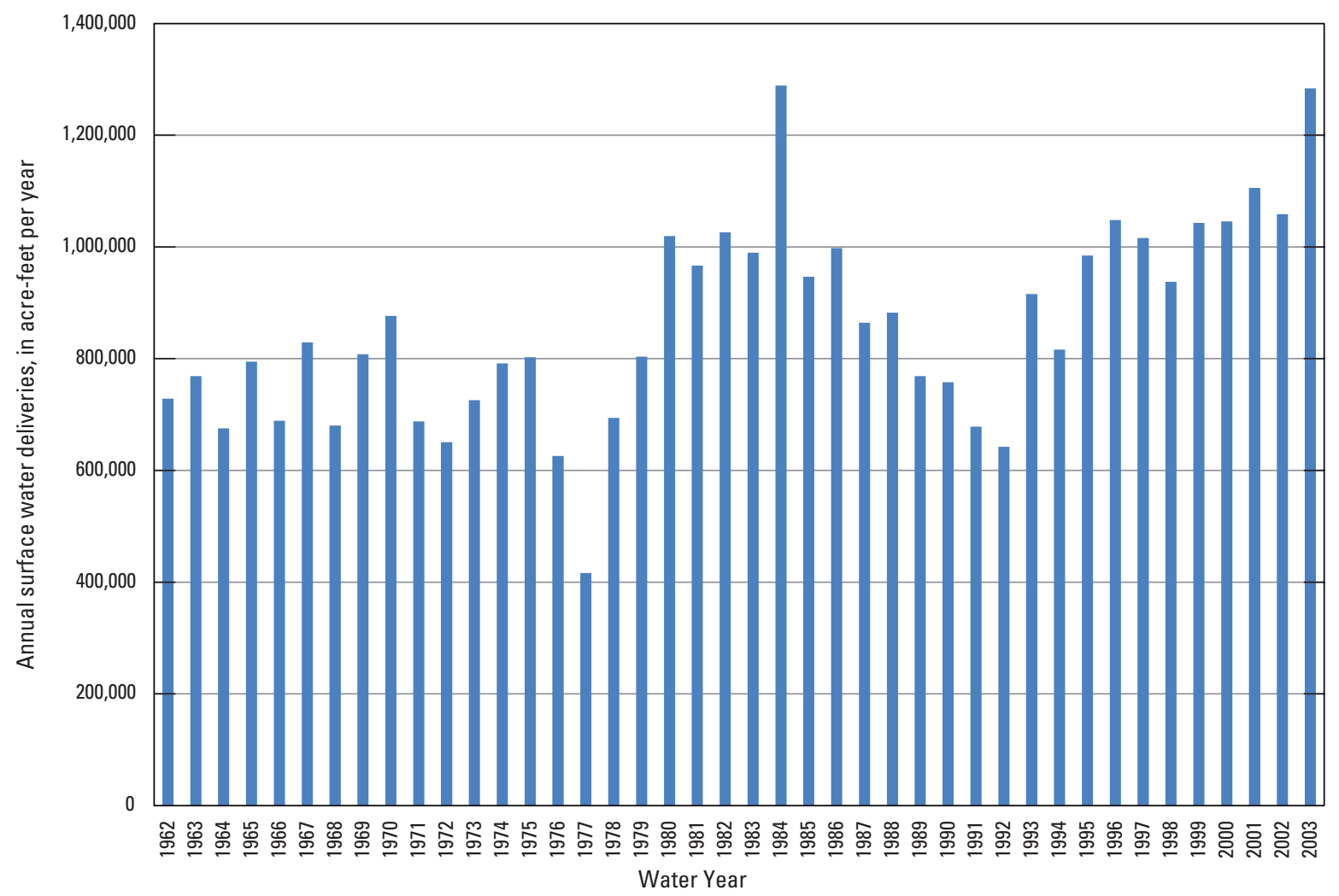

Figure 15. Annual surface-water deliveries to the study area, San Joaquin Valley, California.

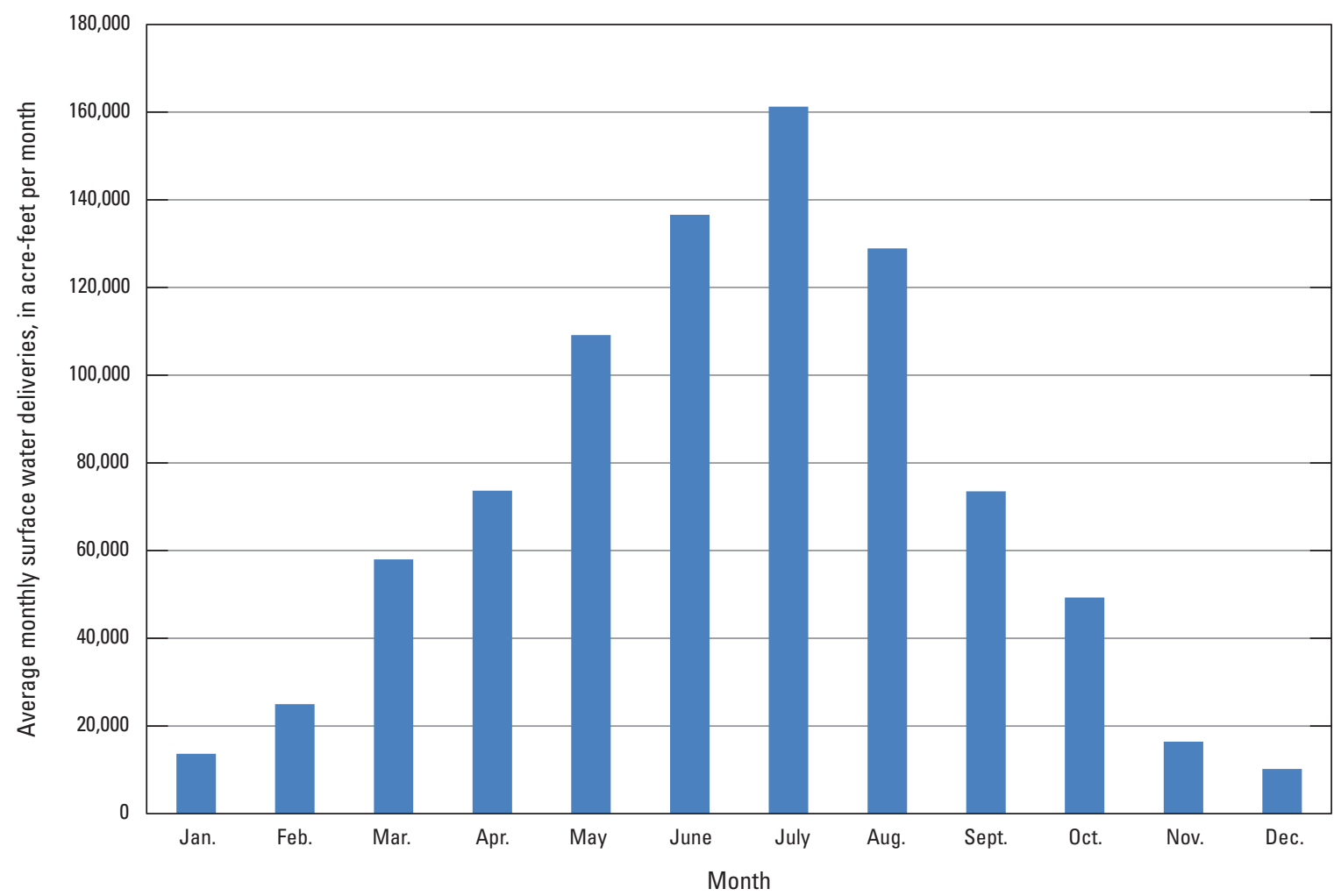

Figure 16. Monthly average surface deliveries to the study area, San Joaquin Valley, California. 


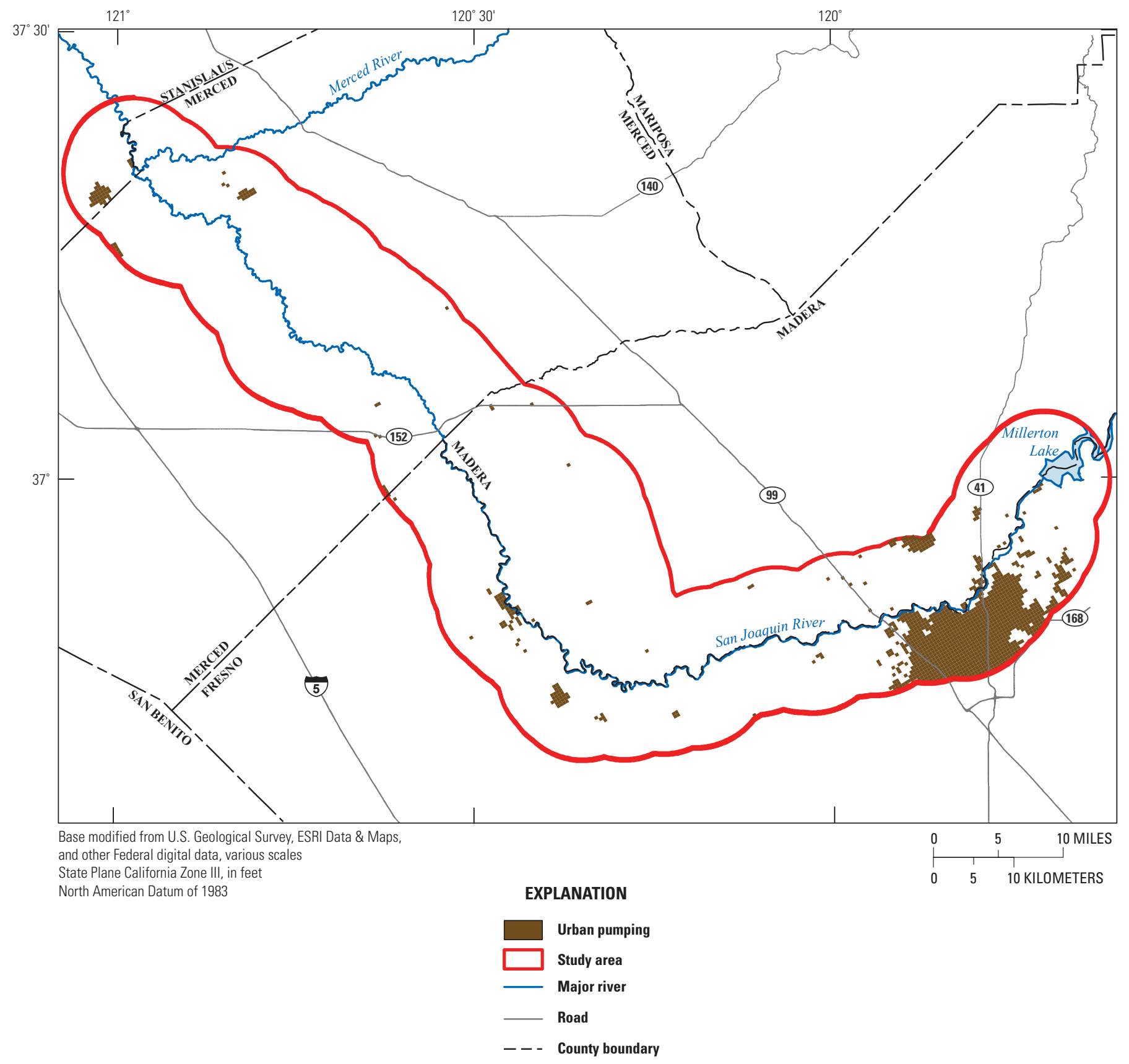

Figure 17. Estimated spatial distribution of urban groundwater pumping in the study area for April 1999-September 2003, San Joaquin Valley, California. 

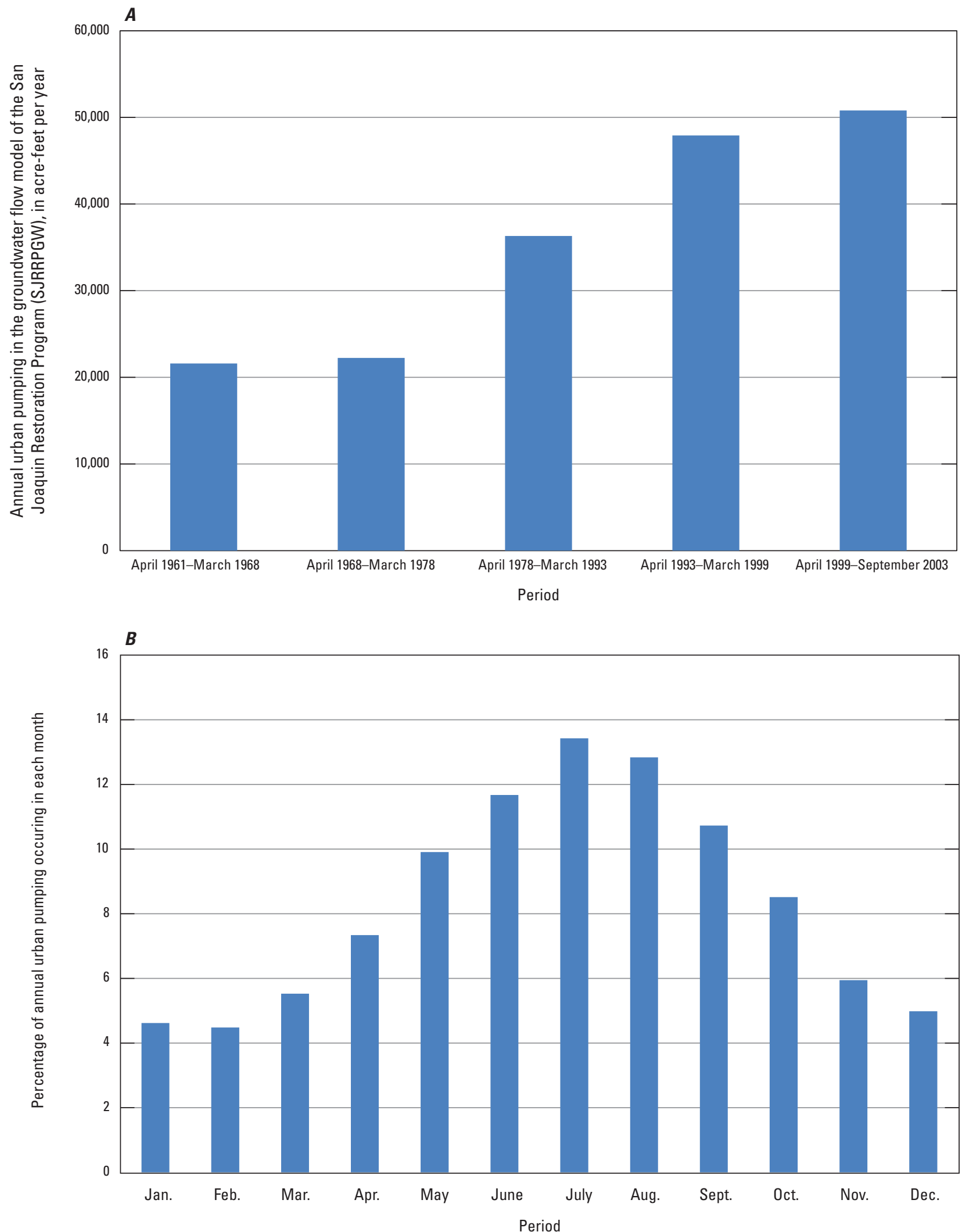

Figure 18. Estimated urban groundwater pumping in the study area, San Joaquin Valley, California: $A$, Annual; $B$, Monthly. 


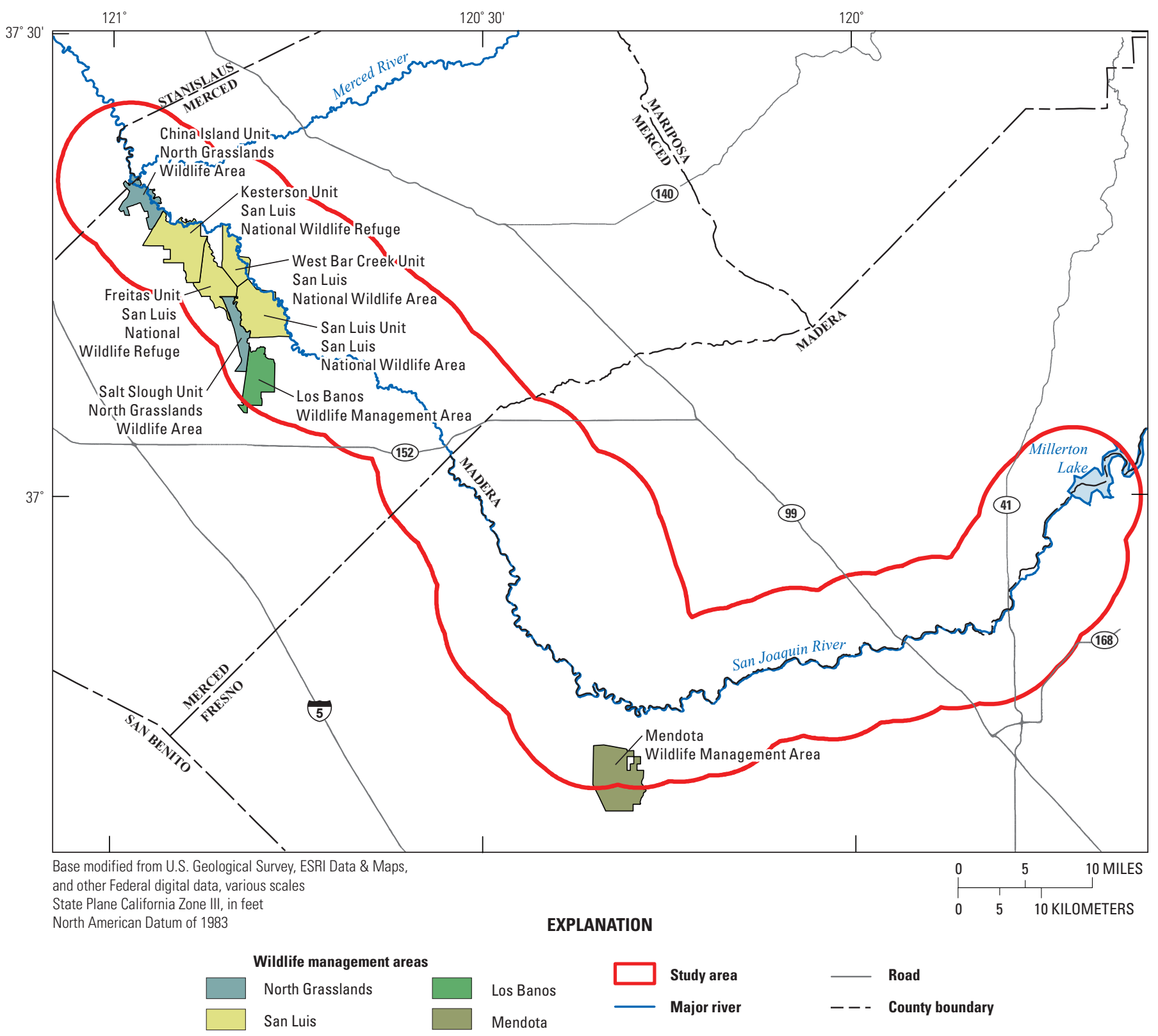

Figure 19. Wildlife management areas simulated in the study area, San Joaquin Valley, California. 
Table 6. MODFLOW packages and processes used in the San Joaquin River Restoration Program groundwater flow model (SJRRPGW), San Joaquin Valley, California.

[Abbreviations: CVHM, Central Valley Hydrologic Model; TPROGS, Transition-probability geostatistical software; - , no data]

\begin{tabular}{|c|c|c|c|c|}
\hline $\begin{array}{c}\text { MODFLOW } \\
\text { package or process }\end{array}$ & Acronym & Function & $\begin{array}{l}\text { Model } \\
\text { input data }\end{array}$ & Reference \\
\hline Basic & BAS6 & $\begin{array}{l}\text { Defining initial conditions and } \\
\text { active model layers }\end{array}$ & $\begin{array}{l}\text { Initial groundwater levels, active model cells for } \\
\text { each layer }\end{array}$ & Harbaugh, 2005 \\
\hline Discretization & DIS & $\begin{array}{l}\text { Defining spatial and temporal } \\
\text { discretization }\end{array}$ & $\begin{array}{l}\text { Grid definition, layer definition, simulation } \\
\text { period, stress period and time-step length, } \\
\text { ground-surface elevation }\end{array}$ & Harbaugh, 2005 \\
\hline $\begin{array}{l}\text { General-Head } \\
\text { Boundary }\end{array}$ & GHB & $\begin{array}{l}\text { Simulating vertical and horizon- } \\
\text { tal boundary flows into and } \\
\text { out of the model area }\end{array}$ & $\begin{array}{l}\text { Groundwater elevations at model boundary } \\
\text { (from CVHM), boundary conductance }\end{array}$ & Harbaugh, 2005 \\
\hline $\begin{array}{l}\text { Hydrologic Unit } \\
\text { Flow }\end{array}$ & HUF2 & $\begin{array}{l}\text { Defining the properties or aqui- } \\
\text { fer material }\end{array}$ & $\begin{array}{l}\text { Hydraulic conductivity, specific yield, and spe- } \\
\text { cific storage for each class of aquifer material }\end{array}$ & $\begin{array}{l}\text { Anderman and Hill, } \\
\text { 2000, } 2003\end{array}$ \\
\hline Hydmod & HYD & $\begin{array}{l}\text { Generating time-series model } \\
\text { output for calibration wells } \\
\text { and streamgages }\end{array}$ & Location of streamgages and observation wells & $\begin{array}{l}\text { Hanson and Leake, } \\
1999\end{array}$ \\
\hline Name & NAM & $\begin{array}{l}\text { Defining the names of the input } \\
\text { and output files }\end{array}$ & - & Harbaugh, 2005 \\
\hline Output Contol & $\mathrm{OC}$ & $\begin{array}{l}\text { Defining when model output is } \\
\text { printed }\end{array}$ & - & Harbaugh, 2005 \\
\hline $\begin{array}{l}\text { Preconditioned } \\
\text { Conjugate- } \\
\text { Gradient }\end{array}$ & PCG & $\begin{array}{l}\text { Solving the finite difference } \\
\text { equations }\end{array}$ & - & Harbaugh, 2005 \\
\hline Well & WEL & $\begin{array}{l}\text { Defining urban groundwater } \\
\text { pumping }\end{array}$ & Municipal-well lcoations, municipal & Harbaugh, 2005 \\
\hline
\end{tabular}




\section{Spatial and Temporal Discretization}

\section{Spatial Discretization}

The study area (fig. 1) is encompassed within a finitedifference grid containing 304 rows and 248 columns with a grid cell size of $0.25 \mathrm{mi}$ by $0.25 \mathrm{mi}$ (fig. 20). The grid is rotated by 34 degrees west of north to coincide with the CVHM grid such that groups of 16 SJRRPGW cells overlay each CVHM cell. Each layer in the grid contains a total of 75,392 cells, of which 21,395 are active, for a total active area of $1,337 \mathrm{mi}^{2}$. Some of the active cells in SJRRPGW are outside the CVHM domain (fig. 20). These 1,419 SJRRPGW cells are active for simulating streamflow and certain landsurface processes (such as ET of native vegetation and routing of precipitation to the stream system) but are inactive for simulating groundwater flow, resulting in 19,976 SJRRPGW cells being active for groundwater flow.

The SJRRPGW is vertically discretized into five layers. The top of layer 1 is the mean ground-surface elevation in each cell. Layer 1 elevations were modified where necessary to slope downhill in cells with streams. The bottom of layer 5 coincides with the top of the Corcoran Clay, a lowpermeability unit. Layers 1-3 are each $16.7 \mathrm{ft}$ thick; layer 4 is $100 \mathrm{ft}$ thick; and layer 5 is the remaining thickness down to the Corcoran Clay (116 ft average).

The five SJRRPGW layers coincide with the upper three layers of CVHM. Layers 1-3 of the SJRRPGW correspond to layer 1 of the CVHM; layer 4 of the SJRRPGW corresponds to layer 2 of the CVHM; and layer 5 of the SJRRPGW corresponds to CVHM layer 3. This refinement of the shallow part of the aquifer system allows for more accurate representation of near-surface physical features and increases the capability of accurate simulation of the shallow water table.

\section{Temporal Discretization}

The SJRRPGW is a transient model that simulates monthly groundwater and surface-water flow from April 1961 through September 2003. This 42.5-year simulation period coincides with that of the CVHM, which is used for SJRRPGW external groundwater elevation and streamflow and boundary conditions. In addition to corresponding to the CVHM, the 1961-2003 period is associated with a range of climatic variability such as the 1976-77 and 1987-92 droughts and the 1982-1984 and 1995-2000 wet periods. Also, several key datasets needed for model development (for example, surface-water deliveries) and calibration (for example, groundwater elevations) are available during the 1961-2003 period.

The simulation period is 510 monthly stress periods; time-varying input data, such as ET, rainfall, and stream inflow, are specified as monthly average values for each stress period. The stress periods were further divided into two equallength time steps, primarily to aid in numerical convergence.
Model output such as groundwater elevations, stream stage, and flow components of groundwater, surface water, and irrigated agriculture were calculated for each time step.

\section{Simulation of Irrigated Agriculture and Other Land-Surface Processes}

The FMP2 (Schmid and Hanson, 2009) was used to simulate the supply and demand components of irrigated agriculture as well as other land-surface processes. The components and processes simulated include precipitation, surface-water delivery, pumping of groundwater, plant uptake of shallow groundwater, plant evapotranspiration, on-farm efficiencies, precipitation runoff, irrigation runoff, and percolation to groundwater. This report provides an overview of how the FMP2 functions with regard to those components used for the SJRRPGW. For a comprehensive description of the FMP2, including its theoretical and mathematical underpinnings, the FMP2 documentation (Schmid and Hanson, 2009) should be consulted.

\section{Subregion Definitions}

The FMP2 simulates key processes on the basis of groups of cells called subregions. The SJRRPGW was divided into 28 subregions (table 7 and fig. 21). Because the dominant land use in the study area is irrigated agriculture, the subregions are defined primarily on the basis of the boundaries of water purveyors in the study area, including water districts, irrigation districts, and municipal service areas. In areas not organized into water or irrigation districts, the subregion boundaries are based on rivers. Because the subregion divisions are based on the boundaries of water purveyors, the divisions also coincide with the available data on surface-water deliveries.

\section{Irrigation Water Demand}

For each model cell, the irrigation requirement is a function of crop type and $\mathrm{ET}_{\mathrm{o}}$. For every stress period, each cell is assigned a crop type on the basis of the dominant land use in that cell as shown in the maps of crop distribution (fig. $11 A-E$ ). The irrigation requirement for a cell is calculated by FMP2 as the product of $\mathrm{ET}_{\mathrm{o}}$ and the crop coefficient for the crop type. The irrigation requirement is then increased to account for evaporation of irrigation water. The irrigation demand for a cell is calculated by dividing the irrigation requirement by the irrigation efficiency, which is specified for each crop in each subregion. The total irrigation demand for a subregion is calculated by summing the irrigation demand for each model cell in the subregion. This calculation is done for each model stress period, because the crop type, $\mathrm{ET}_{\mathrm{o}}$, irrigation efficiencies, and some of the crop properties can change with each stress period. 


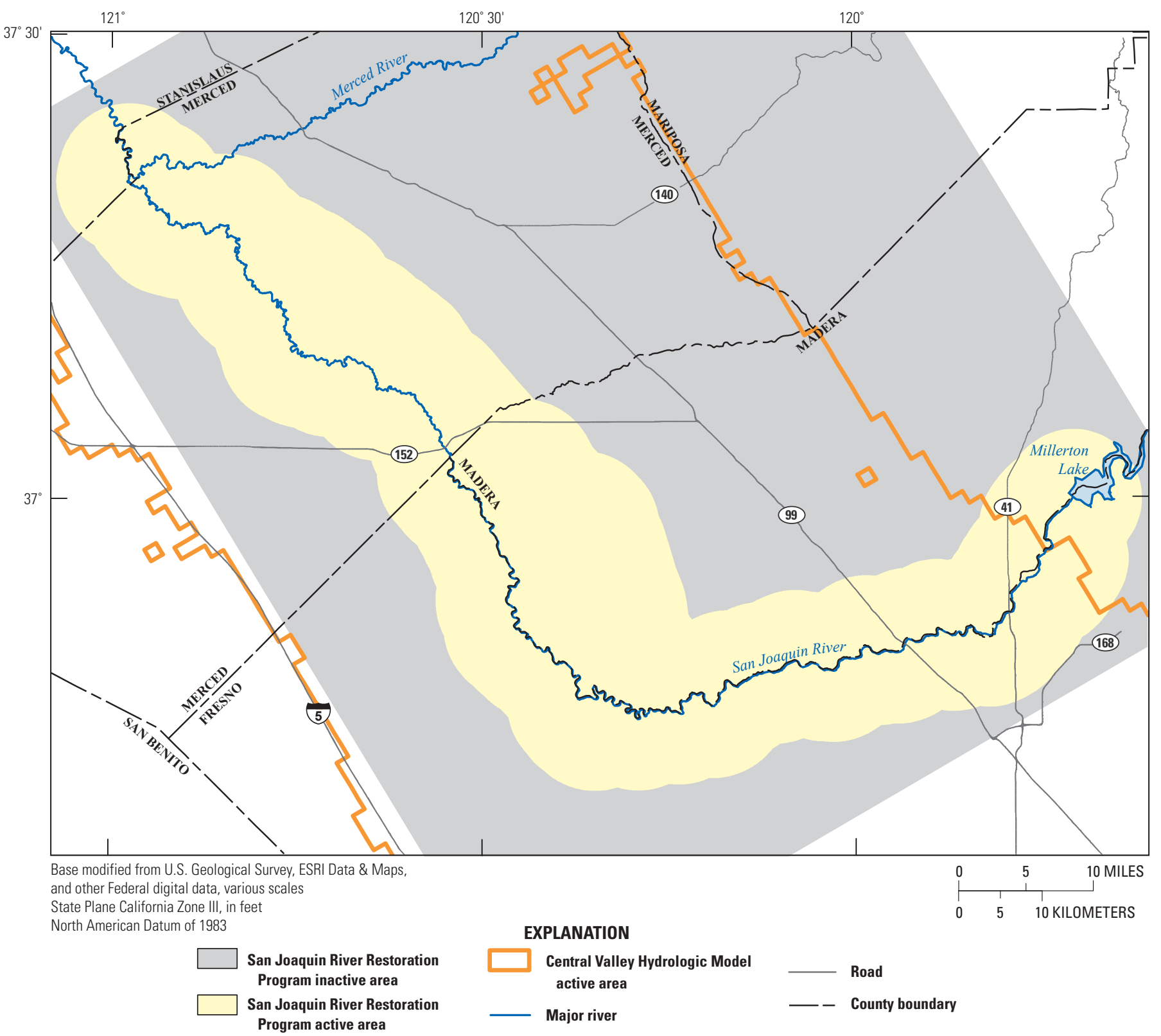

Figure 20. San Joaquin River Restoration Program groundwater flow model (SJRRPGW) grid, San Joaquin Valley, California. 
Table 7. San Joaquin River Restoration Program groundwater flow model (SJRRPGW) subregion descriptions, San Joaquin Valley, California.

[Abbreviations: I.D., Irrigation District; W.D., Water District]

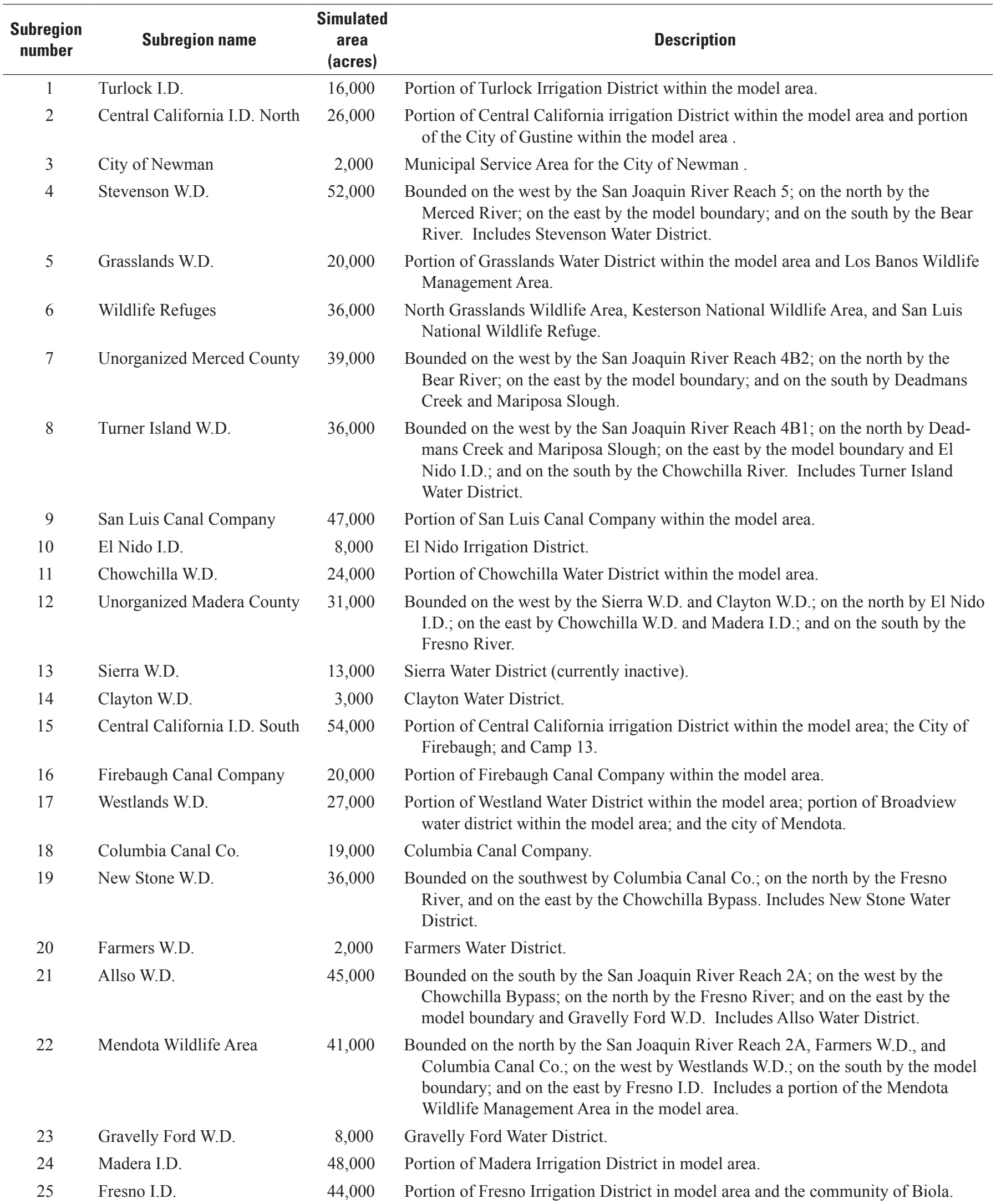


Table 7. San Joaquin River Restoration Program groundwater flow model (SJRRPGW) subregion descriptions, San Joaquin Valley, California.-Continued

[Abbreviations: I.D., Irrigation District; W.D., Water District]

\begin{tabular}{clcc}
$\begin{array}{c}\text { Subregion } \\
\text { number }\end{array}$ & Subregion name & $\begin{array}{c}\text { Simulated } \\
\text { area } \\
\text { (acres) }\end{array}$ & Description \\
\hline 26 & Bonadelle Ranchos & 72,000 & $\begin{array}{c}\text { Bounded on the southeast by the San Joaquin River Reach 1A, on the west by } \\
\text { Madera I.D., and on the north by the model boundary. Includes a portion of the } \\
\text { community of Bonadelle Ranchos. }\end{array}$ \\
27 & City of Fresno & $\begin{array}{c}\text { Portion of the city of Fresno in the model area, portion of the city of Clovis in the } \\
\text { model area, and Pinedale County W.D. }\end{array}$ \\
$28 \quad$ Foothills & $39,000 \quad \begin{array}{c}\text { Bounded on the northwest by the San Joaquin River Reach 1A, on the south by the } \\
\text { cities of Fresno and Clovis, on the east by the model boundary. }\end{array}$ \\
\hline
\end{tabular}

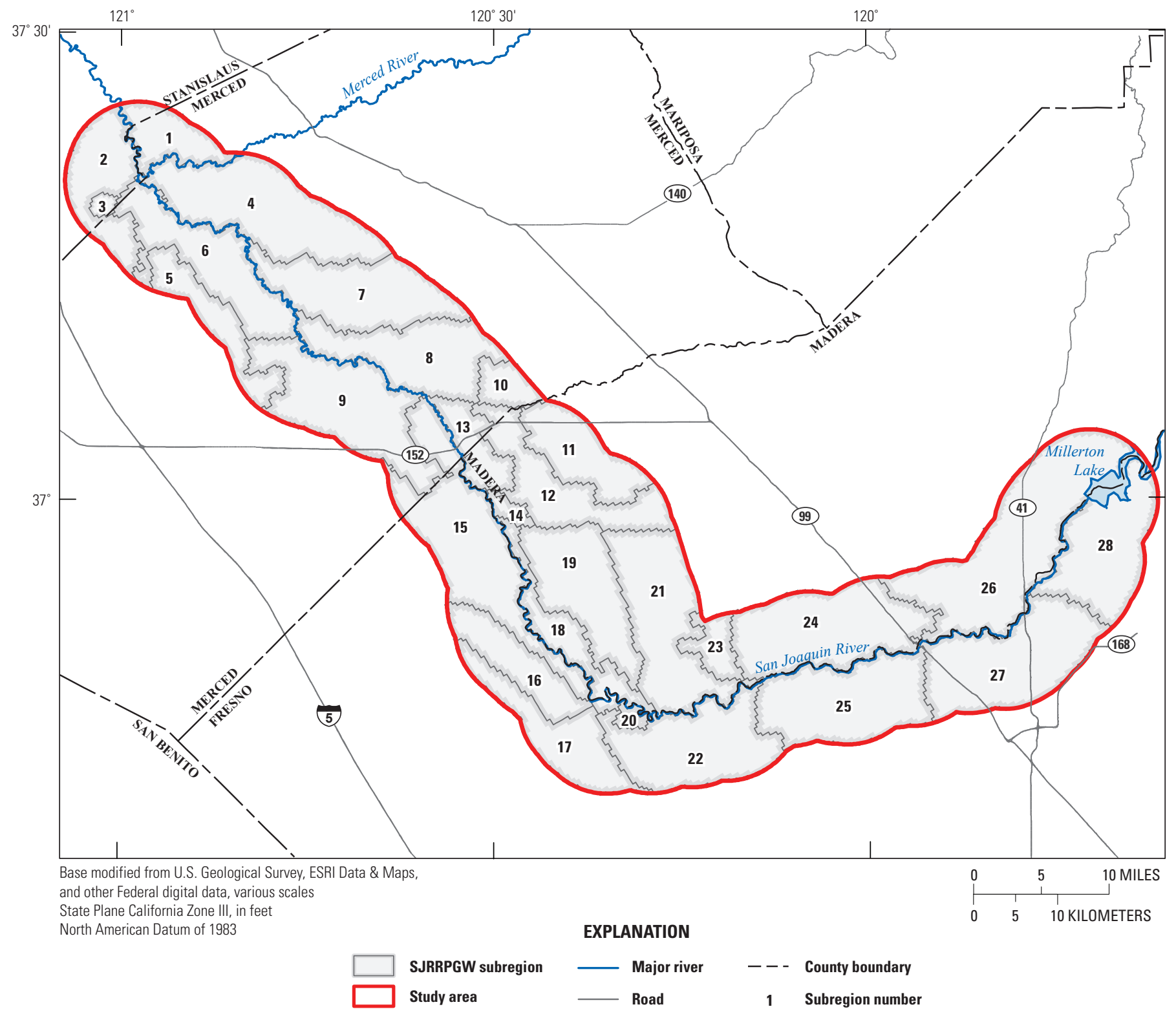

Figure 21. San Joaquin River Restoration Program groundwater flow model (SJRRPGW) subregions, San Joaquin Valley, California. 


\section{Irrigation Water Supply}

Water to meet the irrigation demand of a subregion is supplied, in this order, by precipitation, root uptake of shallow groundwater, surface-water deliveries, and groundwater production. For each subregion, FMP2 first meets irrigation demand with precipitation, which is reduced by a cropdependent precipitation runoff factor and then bygroundwater uptake. Next, FMP2 attempts to meet the remaining irrigation demand with surface-water delivery, which also is reduced by a crop-dependent irrigation runoff factor. If any irrigation demand is unmet by surface-water delivery, the FMP2 calculates the groundwater production needed for each subregion to meet the remaining irrigation demand. For non-irrigated crop types, such as native vegetation, the FMP2 reduces the consumptive use of the crop such that the evapotranspiration from the crop does not exceed available water (precipitation and groundwater uptake).

Data on the location and properties of the active agricultural production wells are not available for the study area. For the SJRRPGW, a virtual, or hypothetical, agricultural well was placed in each model cell containing an irrigated crop. The virtual agricultural well extracts groundwater during stress periods when the FMP2 calculates a remaining irrigation demand for that cell. The total monthly groundwater production calculated by FMP2 is distributed evenly to all active agricultural wells in each subregion.

The virtual well approach simulates a total of 19,976 wells, which is more than are estimated to exist in the study area. Thus, each virtual well generally is pumping less water than a typical irrigation well would pump. Therefore, the SJRRPGW tends to underestimate local drawdowns near real irrigation wells and, conversely, tends to overestimate local drawdowns in areas distant from real irrigation wells. However, the virtual well approach reasonably estimates regional drawdowns.

\section{Development of Farm Process Datasets}

Ground-surface elevation is used by the FMP2 to route runoff from rainfall and irrigation to the simulated streams and to estimate transpiration of shallow groundwater. Soils data are used to define the capillary fringe depth and other parameters that influence transpiration from groundwater. Precipitation data are used to calculate water supply, runoff, and percolation to groundwater associated with rainfall. Values of ET and crop coefficients are used with land-use and crop data to calculate the potential evapotranspiration for each model cell.

Monthly agricultural surface-water deliveries to each model subregion were determined by aggregating all available data. If data were not available at the scale of the subregion, deliveries were estimated by using the available data at a larger scale, such as a Detailed Analysis Unit (DAU), and multiplying by the fractional area of agricultural land in the DAU that is within the subregion. Similarly, for areas served by water purveyors that are clipped by the model boundary, the surface-water delivery to the portion within the study area was estimated by multiplying the total delivery to the purveyor by the percentage of the agricultural land within the study area.

In addition to irrigated crops, a specific crop type, called irrigated native vegetation, was defined for the wildlife management areas. The crop water-use parameters for irrigated native vegetation are the same as non-irrigated native vegetation, but the crop type is irrigated. As with other irrigated lands, virtual wells were placed in each model cell in the wildlife management areas. This assumption is consistent with the DWR DAU water budgets, which indicate groundwater as a source for some wildlife management areas to provide adequate water supplies to native vegetation to keep it healthy and not stressed (Chris Montoya, California Department of Water Resources, written commun., 2011).

\section{Simulation of Surface Water}

The SJRRPGW simulates streamflow and groundwater/ surface-water interactions for the major streams and bypasses in the study area using the Streamflow-Routing Package (SFR2) (Niswonger and Prudic, 2005). The streamflow network is simulated using 1,697 stream reaches, each corresponding to an SJRRPGW model cell that underlies the stream network. The stream reaches were grouped into 91 stream segments, such that reaches in each segment had similar hydrologic characteristics. These hydrologic characteristics include the streambed slope and the relation between the stream stage, width, and discharge (stream rating table). For the San Joaquin River, Chowchilla Bypass, Eastside Bypass, and Mariposa Bypass, these characteristics were obtained from a Hydrologic Engineering Centers River Analysis System (HEC-RAS) model of the San Joaquin River (Tetra Tech, 2010). For other simulated streams, these characteristics were obtained from the CVHM datasets (Faunt, 2009).

Measured streambed elevations used to construct the HEC-RAS model were highly variable, and the discretization was much smaller than for the SJRRPGW cells; therefore, a smoothed representation was used for model input. An example of the measured streambed elevations for the Chowchilla Bypass Bifurcation Structure and the simplified streambed elevations used in the SJRRPGW are shown in figure 22. The stream stage-discharge relation for the Chowchilla Bypass is also shown in figure 22. The vertical lines show the segment divisions that were placed where major changes occur in either the streambed slope or the stream rating table.

\section{Calculation of Streamflow}

The SFR2 tracks streamflow within the SJRRPGW by routing the flow in each of the stream segments to the next downstream segment. Surface water enters the SJRRPGW at 10 locations where inflow data are available. Nine of these segments are located where the streams enter the model boundary. The 10th inflow is from the Delta Mendota Canal 


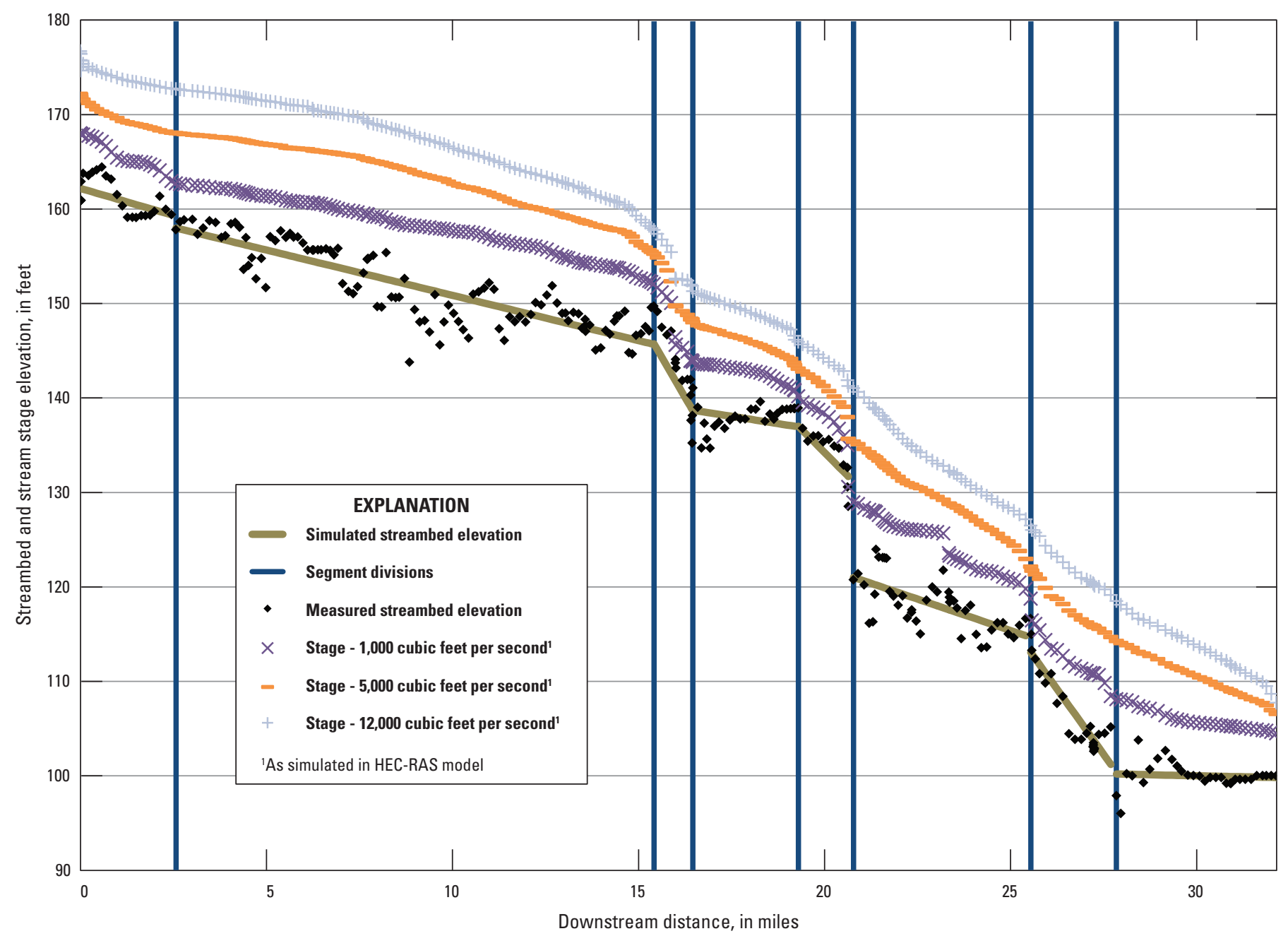

Figure 22. Streambed elevation along Chowchilla Bypass, San Joaquin Valley, California.

at Mendota Pool on the San Joaquin River (segment 35); this inflow is added to the other flows entering the stream segment from within the study area.

Surface water exits the SJRRPGW at the farthest downstream segment on the San Joaquin River (segment 91) and at Sack Dam on the San Joaquin River (segment 45). The Sack Dam diversion is based on historical data and results in some (or all) of the flow being diverted out of the streamflow network.

Many confluences in the SJRRPGW route water from two stream segments to the same downstream segment. There are also three bifurcations where outflow may be divided into two downstream segments, on the basis of historical data. These bifurcations are at Chowchilla Bypass Bifurcation Structure (segment 26), Sand Slough Bypass Control Structure (segment 56), and Mariposa Bifurcation Structure (segment 66) (fig. 5).

Within a stream segment, SFR2 routes the outflow from one reach to the next downstream reach. In each reach, flow can be increased or decreased because of the interaction of surface water and groundwater or can be increased because of runoff of irrigation water or precipitation calculated by the FMP2.

\section{Interaction of Surface Water and Groundwater}

SFR2 calculates the stream stage on the basis of the streambed elevation, flow in the stream, and other stream hydraulic characteristics. SFR2 uses this stream stage to calculate the hydraulic gradient between the stream and the model cell representing the top of the aquifer system underlying the stream. If the stream stage is above the head in the cell (positive hydraulic gradient), the stream loses water to the aquifer system; conversely, if the steam stage is below the head in the cell (negative hydraulic gradient), the stream gains water from the aquifer system.

The magnitude of the stream gain or loss is controlled by the magnitude of the hydraulic gradient and the streambed conductance. Streambed conductance is a property of the length of the stream in the cell, the streambed thickness, 
the stream width, and the streambed hydraulic conductivity. The stream length within a cell was calculated by overlaying the stream network with the model grid using a geographic information system (GIS) software. The streambed thickness is assumed to be $3.28 \mathrm{ft}(1 \mathrm{~m})$. The streambed hydraulic conductivity was initially set to 1 foot per day (ft/d) for all segments, but it was modified during calibration.

Tile Drains (fig. 5) are present in the southwest corner of the model in the eastern portion of the Grasslands Drainage Area. These drains are not simulated in the model because specific information on the drains is not available to the extent that would be needed to include them in the simulation (such as the depth of drain laterals and the time series of flow rates). In addition, most of the drained area is outside the model boundary. The lateral general-head boundary imposed on the SJRRPGW in this area attempts to account for the net effects of tile drainage in the Grasslands Drainage Area on the model. Note, the SFR2 segments that have no inflow component (such as Mud and Salt Slough) gain flow from groundwater and runoff and, thus, act like drains in the simulation.

\section{Simulation of Groundwater}

\section{Initial Conditions}

Calibration of a steady-state simulation to calculate the initial groundwater elevations was not done for the SJRRPGW because of minimal observations available prior to and during the early period of human development in the area in the late 1800s. Initial groundwater elevations used in the model were estimated by developing a map of the spring 1961 groundwater elevation. Measurements for 611 wells for the period mid-February through early-May 1961 were selected to represent spring conditions. This particular period was selected in order to maximize the number of data points and to avoid measurements of groundwater elevation that coincided with the onset of the growing season. For wells having multiple measurements, the date closest to the middle of that period (last week of March) was selected. Groundwater elevations that indicated possible measurement error or non-static conditions or that appeared to represent dynamic conditions were excluded.

The map of groundwater elevation for spring 1961 was developed using GIS software and the inverse distance weighting (IDW) method of interpolation with a $32.8 \mathrm{ft}(10 \mathrm{~m})$ grid. This grid was then overlain onto the SJRRPGW grid for calculating the initial groundwater elevations. Using this method, the computed groundwater-elevation map represents composite groundwater levels aggregated vertically and distributed areally.

The spring 1961 groundwater elevation was used as the initial groundwater elevation for all five model layers. The model was then run for 12 stress periods ( 1 year). The resulting heads were subsequently used as the spring 1961 starting heads (fig. 23). This method dissipates the head and flow transients in the model caused by the inherent disequilibrium related to the compositely estimated initial heads and establishes vertical head gradients between model layers on the basis of their relative hydrogeologic properties. During calibration, this procedure was periodically repeated as the model parameters changed to ensure the initial conditions were consistent with the final calibrated parameters.

\section{Boundary Conditions}

The lateral and lower boundary conditions are simulated using the General-Head Boundary (GHB) Package (Harbaugh, 2005), which calculates head-dependent flows into and out of the study area. The direction and magnitude of this crossboundary flow is governed by a specified head representing conditions outside the model and a specified conductance value of aquifer materials between the outermost active cell and the specified head location. The heads for the lateral general-head boundaries were specified for each model stress period using the calculated head values from the CVHM in the cells adjacent to the SJRRPGW boundary. The specified lateral or horizontal conductance $\left(C_{\mathrm{bh}}\right)$ values for the lateral generalhead boundaries were estimated using the following equation:

$$
C_{b h}=K_{h} \times \frac{A}{L}
$$

where

A is the cross-sectional area of the SJRRPGW cell (0.25 $\mathrm{mi} *$ layer thickness),

$L \quad$ is the distance of general head from model boundary (a calibrated parameter), and

$K_{\mathrm{h}} \quad$ is horizontal hydraulic conductivity (a calibrated parameter).

During model calibration, the value of $K_{\mathrm{h}} / L$ was estimated for three sections of the model boundary (fig. 24), as opposed to using $K_{\mathrm{h}} / L$ values based on the CVHM. The purpose for this approach is rooted in the local performance of the CVHM, which matches observed groundwater elevations well along the western side along the valley axis, horizontal GHB zone 1 (fig. 24); less well along the opposite boundary, horizontal GHB zone 2; and poorly in the Fresno area, closer to Friant Dam, horizontal GHB zone 3. Calibrating the conductance values separately for various sections of the boundary (fig. 24) permitted flexibility to strengthen the simulated hydraulic connection between the CVHM and SJRRPGW where the boundary heads matched observed heads and to weaken the simulated connection where the match to observed heads by the CVHM was poor.

The specified general-head value for each cell of the lower boundary was assigned for each model stress period using the calculated head from layer 6 of the CVHM, which represents the aquifer underlying the Corcoran Clay. The specified lower or vertical hydraulic conductance was estimated using equation 1 , substituting $\mathrm{C}_{\mathrm{bv}}$ for $\mathrm{C}_{\mathrm{bh}}$ and vertical hydraulic conductivity $\left(\mathrm{K}_{\mathrm{v}}\right)$ for $\mathrm{K}_{\mathrm{h}}$, 


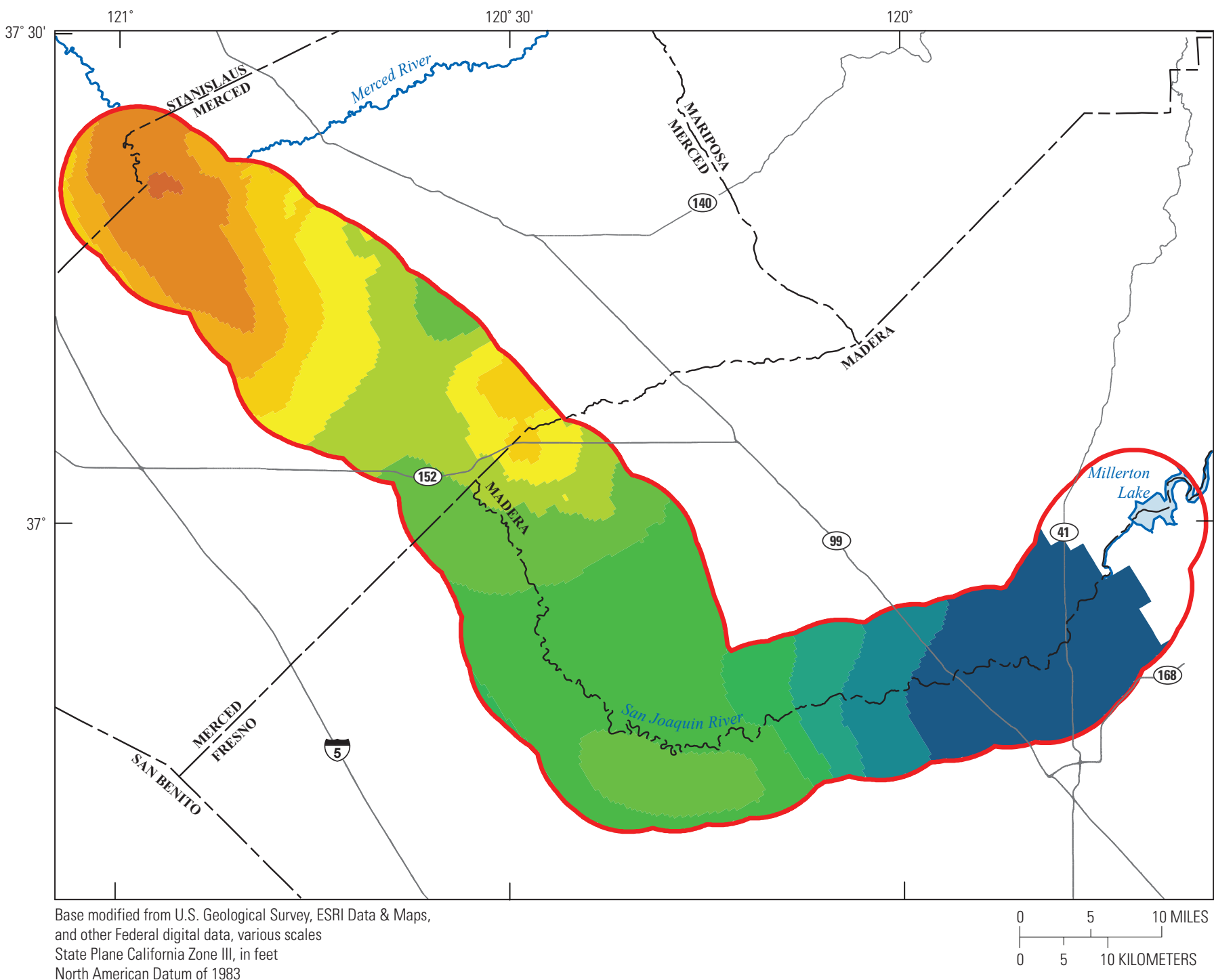

North American Datum of 1983

EXPLANATION

\begin{tabular}{|c|c|c|c|}
\hline \multicolumn{2}{|c|}{$\begin{array}{l}\text { Initial groundwater elevation, } \\
\text { in feet }\end{array}$} & & Study area \\
\hline$<40$ & $>100$ to 120 & & Inajor her \\
\hline$>40$ to 50 & $>120$ to 140 & & Koad \\
\hline$>50$ to 60 & $>140$ to 160 & & County boundary \\
\hline$>60$ to 70 & $>160$ to 180 & & \\
\hline$>70$ to 80 & $>180$ to 200 & & \\
\hline$>80$ to 90 & $>200$ to 300 & & \\
\hline$>90$ to 100 & $>300$ & & \\
\hline
\end{tabular}

Figure 23. San Joaquin River Restoration Program groundwater flow model (SJRRPGW) initial groundwater elevation, San Joaquin Valley, California. 


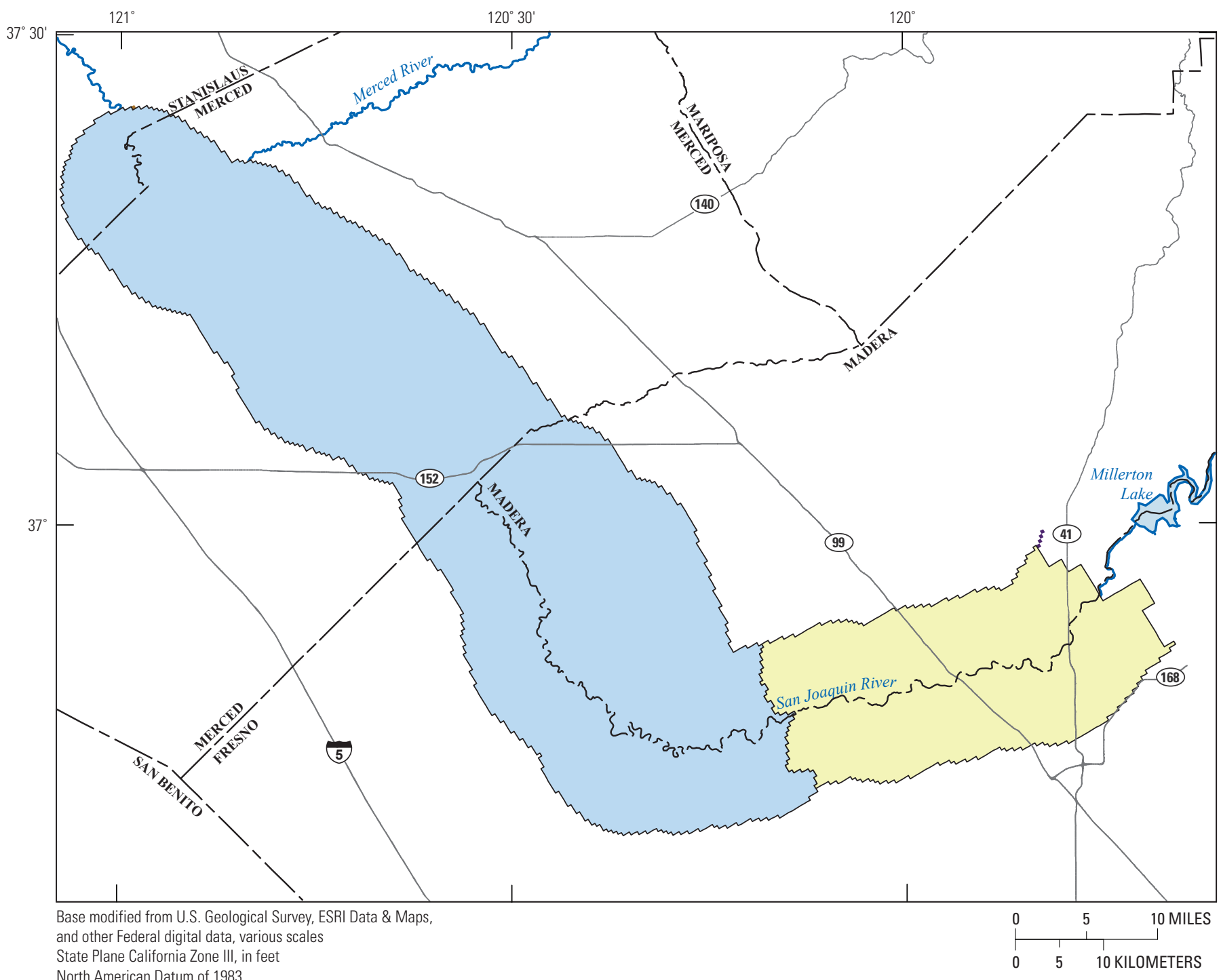

North American Datum of 1983

\section{EXPLANATION}

\begin{tabular}{|c|c|c|c|}
\hline $\begin{array}{c}\text { Vertical } \\
\text { General-Head } \\
\text { Boundary zone }\end{array}$ & $\begin{array}{c}\text { Horizontal } \\
\text { General-Head } \\
\text { Boundary zone }\end{array}$ & $\overline{ }$ & \multirow{2}{*}{$\begin{array}{l}\text { Major river } \\
\text { Road } \\
\text { County boundary }\end{array}$} \\
\hline$\square 1$ & -1 & --- & \\
\hline 2 & $\longrightarrow 2$ & & \\
\hline
\end{tabular}

Figure 24. San Joaquin River Restoration Program groundwater flow model (SJRRPGW) division of general-head model boundaries, San Joaquin Valley, California. 
where

$A \quad$ is the area of the SJRRPGW cell $(0.25 \mathrm{mi} *$ $0.25 \mathrm{mi})$, and

$L \quad$ is the thickness of Corcoran Clay (estimated by the total thickness of layers 4 and 5 in the CVHM, or a value of $2 \mathrm{ft}$ where the Corcoran Clay is not present).

During model calibration, the value of $K_{\mathrm{v}}$ was estimated for two parts of the model (fig. 24) as described above for the lateral boundaries.

\section{Aquifer Properties}

The program TPROGS (Carle, 1999) was used to develop 100 equally probable three-dimensional sediment-texture distributions, or models, of the study area on the basis of data from 616 drillers' logs and various imposed constraints. The first texture model was chosen arbitrarily as representative of the true distribution of sediment texture in the study area.

The cell size of the texture model grid is $0.125 \mathrm{mi}$ by $0.125 \mathrm{mi}$ laterally, and it is oriented to coincide with the SJRRPGW grid such that groups of four texture model cells overlay one SJRRPGW cell. The vertical resolution of the texture model grid is $3.28 \mathrm{ft}(1 \mathrm{~m})$, which is much finer than that of the SJRRPGW. Sediment texture was grouped into four classes_-gravel, sand, muddy sand, and clay (fig. 4). The texture model grid is a rectangular box shape, whereas the SJRRPGW grid has an irregular top (based on groundsurface elevation) and irregular bottom (based on the top of the Corcoran Clay). The texture model grid extends vertically beyond the top and bottom of SJRRPGW grid; the texture information outside the SJRRPGW grid is not used.
When the texture model and SJRRPGW grids are overlain, the four texture classes and the four texture model grid cells can be combined into 35 possible combinations (256 permutations) horizontally within a SJRRPGW grid cell. These 35 combinations were binned into 5 classes of aquifer materials as follows:

- Gravel - cells (SJRRPGW) with at least 2 gravels and less than 2 muddy sands or clays ( 7 of the possible 35 combinations).

- Sand - cells with at least 2 sands, less than 2 gravels, and less than 2 muddy sands or clays ( 6 of the possible 35 combinations).

- Muddy sand - cells with at least 2 muddy sands and less than 2 sands or gravels ( 7 of the possible 35 combinations).

- Clay_cells with at least 3 clays (4 of the possible 35 combinations).

- Mix - all other combinations (11 of the possible 35 combinations).

An example of a 3 by 3 model-cell section of the SJRRPGW grid illustrating how the texture model cells are combined into the SJRRGW cells is shown in figure 25. A control file that specifies how all 256 permutations are binned into the 5 classes of aquifer materials is available by request with the model archive.

The texture model does not extend all the way to the eastern SJRRPGW model boundary, so a sixth class, called "foothills," is assigned to active model cells that lie outside the texture model boundary. On the basis of these combinations, sand makes up the largest percentage of the SJRRPGW texture, and gravel makes up the least (table 8).

\section{A. Texture in TPROGS grid}

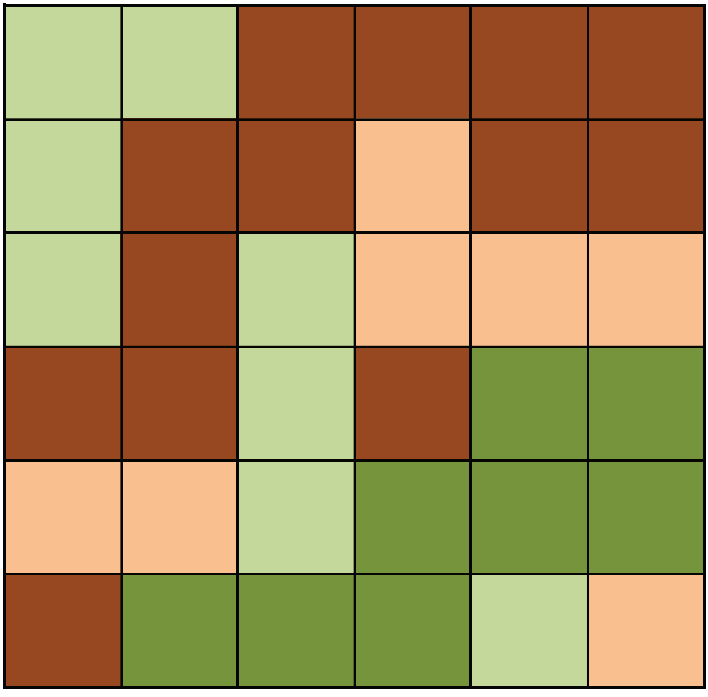

\section{$B$. Texture in MODFLOW grid}

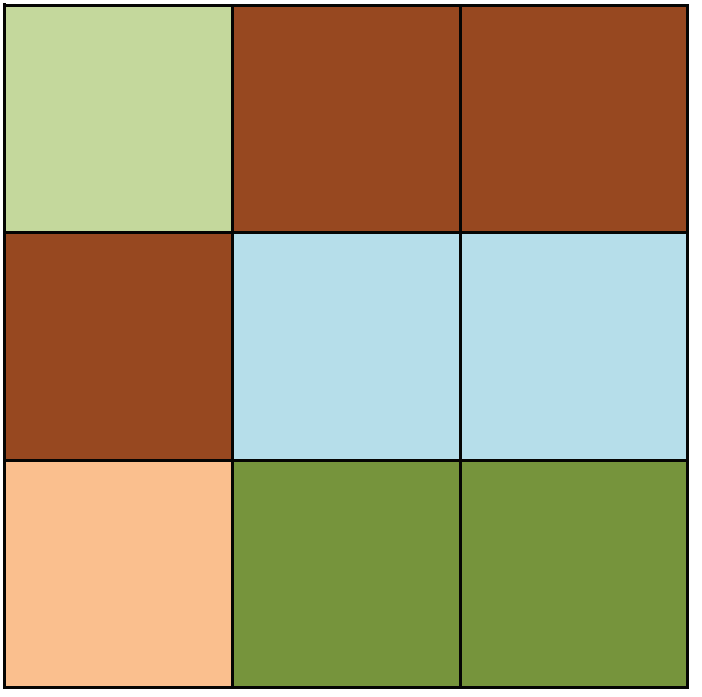

Figure 25. Example of horizontal combination of Transition-Probability Geostatistical Software (TPROGS) grid cells onto the San Joaquin River Restoration Program groundwater flow model (SJRRPGW) grid cells, San Joaquin Valley, California. 
Table 8. Example distribution of aquifer texture in the San Joaquin River Restoration Program groundwater flow model (SJRRPGW), San Joaquin Valley, California.

\begin{tabular}{lc}
\hline \multicolumn{1}{c}{ Aquifer texture } & Percentage \\
\hline Gravel & 3 \\
Sand & 33 \\
Muddy sand & 12 \\
Clay & 25 \\
Mix & 14 \\
Foothills & 13 \\
\hline
\end{tabular}

By using the criteria above, the binned texture class was calculated for each $3.28-\mathrm{ft}(1-\mathrm{m})$ vertical increment at the lateral resolution of the SJRRPGW grid. The interpolation of the 255 3.28-ft layers into the thicker SJRRPGW grid layers was accomplished using the HUF Package (Anderman and Hill, 2000). The HUF Package allows the vertical geometry of the 255 layers, which is supplied by the texture model, to be defined separately from the 5 model layers. An example of how the HUF Package combines vertical texture model layers onto the SJRRPGW model layers is shown in figure 26.

\section{Water-Table Simulation}

Although the uppermost active model layer in the SJRRPGW represents the water table and unconfined groundwater flow, confined flow is simulated in all the layers, which is a necessary and common approach for avoiding numerical instability and long execution times (Hill and Tiedeman, 2007). Attempts to simulate the upper layer as unconfined resulted in an eight-fold increase in model run time and caused convergence failures during the calibration process.

The HUF SYTP option is used to properly represent unconfined aquifer storage (Anderman and Hill, 2003). The SYTP option allows a unitless value of specific yield to be defined to represent the storage coefficient in all uppermost active cells when all model layers are confined. During the calibration process, if the simulated groundwater elevation in a cell was below the bottom elevation of a cell for the entire simulation, that model cell was manually made inactive such that the saturated thickness of the aquifer is not overestimated (fig. 27).

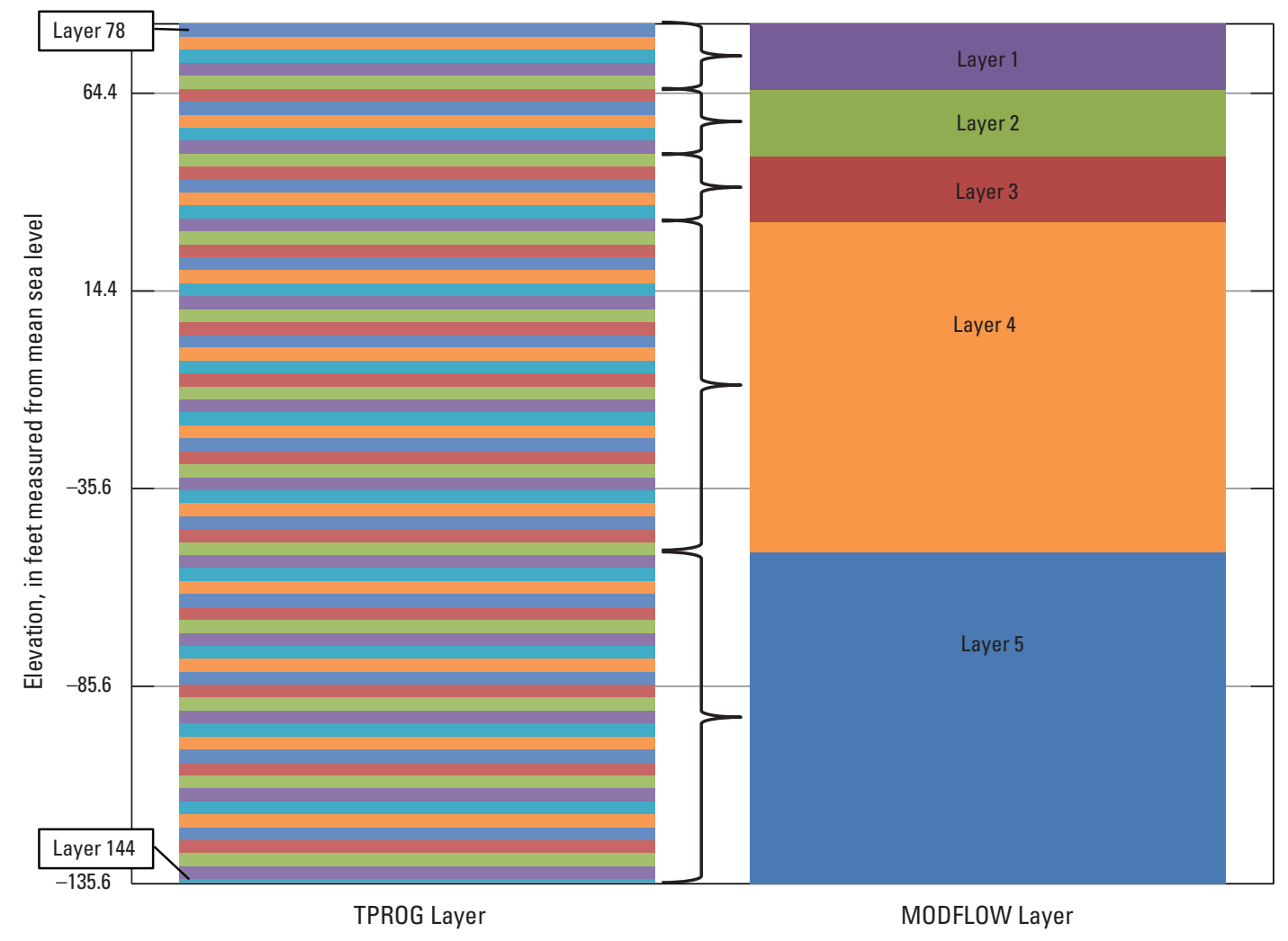

Figure 26. Example Hydrogeologic Unit Flow Package combination of vertical Transition-Probability Geostatistical Software (TPROG) texture layers onto the San Joaquin River Restoration Program groundwater flow model (SJRRPGW) model layers (Row 81, Column 31), San Joaquin Valley, California. 


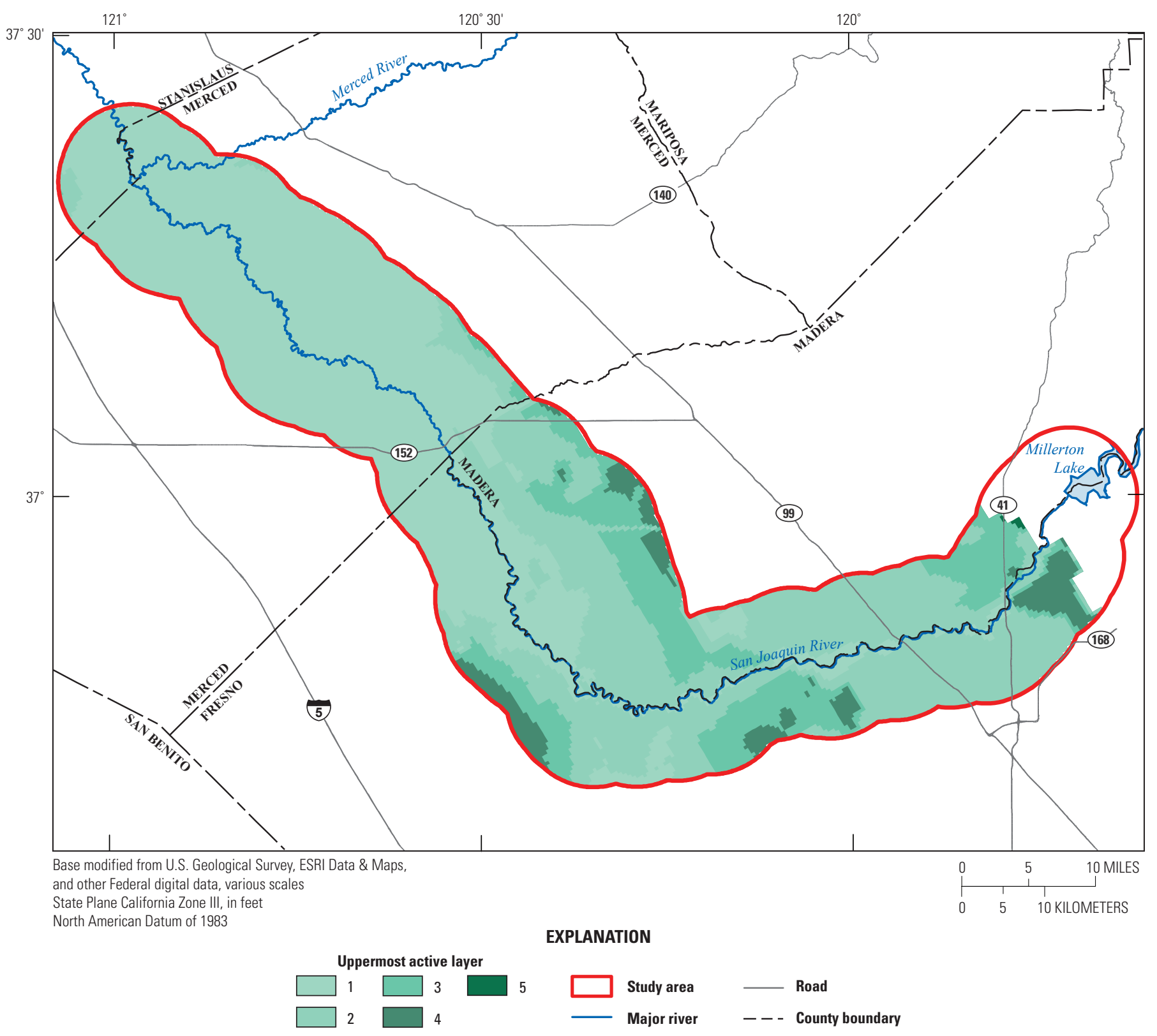

Figure 27. San Joaquin River Restoration Program groundwater flow model (SJRRPGW) uppermost active layer for each model cell, San Joaquin Valley, California. 


\section{Recharge and Discharge}

Sources of groundwater recharge to the SJRRPGW include percolation of rainfall and irrigation water, leakage from streams, and subsurface inflow through the lateral and bottom boundaries of the SJRRPGW. Groundwater discharge from the SJRRPGW occurs as municipal pumping, agricultural pumping, root uptake of shallow groundwater, outflows to streams, and subsurface outflow through the lateral and bottom boundaries of the SJRRPGW.

Percolation of rainfall and irrigation water is simulated by the FMP2. During the rainy season (and sometimes during the growing season), precipitation may exceed the irrigation requirement in a cell. During the growing season, irrigated land will usually have some excess water applied to account for inefficiency (the irrigation efficiency is less than 100 percent). In both cases, this excess water percolates below the root zone and is simulated as groundwater recharge in the model. Agricultural pumping and root uptake of shallow groundwater also are simulated by the FMP2. Leakage from streams and groundwater discharge to streams are simulated by the SFR2 Package.

Subsurface inflow and outflow through the lateral and bottom boundaries of the SJRRPGW are simulated by the General-Head Boundary (GHB) Package. The heads for the general-head boundaries are specified for each model stress period using the calculated head values from the CVHM in the cells adjacent to the SJRRPGW boundary. For each cell, if the head at the SJRRPGW boundary cell is less than the general head, inflow occurs. If the head at the SJRRPGW boundary cell is greater than the general head, outflow occurs.

Municipal well pumping is simulated in the SJRRPGW by using the standard well package of MODFLOW (Harbaugh, 2005). Pumping is estimated on the basis of the amount of urban acreage and was aggregated by the 28 FMP2 subregions. Some of the deeper municipal wells in the study area are screened below the Corcoran Clay and are not directly included in the SJRRPGW, which simulates only the aquifer above the Corcoran Clay. To account for these deep wells, the total municipal pumping for each subregion is scaled on the basis of the percentage of wells in that subregion screened above the Corcoran Clay (table 9). Pumping beneath the Corcoran Clay is simulated in the CVHM and affected the lower boundary condition of the SJRRPGW model simulated using the GHB Package.

Rural population in the study area is estimated, on the basis of 2010 census block group data (National Historical Geographic Information System, 2011), to be less than 25 percent of the total population. Rural domestic groundwater production is expected to be small compared to municipal groundwater production (which is small relative to agricultural
Table 9. Percentage of wells screened above the Corcoran Clay, San Joaquin Valley, California.

[Abbreviations: N/A, not available]

\begin{tabular}{|c|c|c|}
\hline Subregion & $\begin{array}{l}\text { Number of } \\
\text { wells with screen } \\
\text { information }\end{array}$ & $\begin{array}{l}\text { Percentage of } \\
\text { wells screened above } \\
\text { Corcoran Clay }\end{array}$ \\
\hline 1 & 2 & 50 \\
\hline 2 & 6 & 100 \\
\hline 3 & 0 & N/A-Used 100 \\
\hline 4 & 9 & 89 \\
\hline 5 & 8 & 38 \\
\hline 6 & 4 & 100 \\
\hline 7 & 3 & 67 \\
\hline 8 & 9 & 44 \\
\hline 9 & 9 & 100 \\
\hline 10 & 2 & 0 \\
\hline 11 & 9 & 67 \\
\hline 12 & 3 & 100 \\
\hline 13 & 4 & 50 \\
\hline 14 & 0 & N/A-Used 50 \\
\hline 15 & 5 & 100 \\
\hline 16 & 4 & 100 \\
\hline 17 & 19 & 42 \\
\hline 18 & 2 & 100 \\
\hline 19 & 6 & 83 \\
\hline 20 & 4 & 75 \\
\hline 21 & 2 & 100 \\
\hline 22 & 21 & 100 \\
\hline 23 & 1 & 0 \\
\hline 24 & 3 & 100 \\
\hline 25 & 3 & 100 \\
\hline 26 & 3 & 100 \\
\hline 27 & 8 & 88 \\
\hline 28 & 1 & 100 \\
\hline
\end{tabular}

groundwater production). In addition, rural domestic groundwater used indoors is largely returned to the aquifer system through septic systems, and the net rural domestic groundwater extraction is small. Thus, rural water use is not included in the SJRRPGW. Similarly, industrial groundwater pumping in the study area is expected to be small and also is not included in the SJRRPGW. 


\section{Model Calibration}

Hydrologic model calibration can be defined as the process of exploring a range of possible model parameters in order to achieve a set of model parameters for which the respective model results adequately approximate the real hydrologic system. For the SJRRPGW, as with most hydrologic models, the real hydrologic system is represented by a historical set of observed data (such as groundwater elevations and streamflow), which are known and measurable at discrete locations with a degree of uncertainty that is based principally on measurement error. In contrast, the distribution of the parameter values (such as hydraulic conductivity) is largely unknown, except perhaps at a few discrete locations, and can only be constrained by a range of reasonable values that are based on measurements and estimates from previous investigations. In the SJRRPGW, the model parameters adjusted during model calibration include the fllowing:

- Hydraulic conductivity, specific yield, and specific storage.

- Streambed hydraulic conductivity.

- General-head boundary hydraulic conductivity (as described earlier).

- Crop evapotranspiration coefficient.

- Subregion irrigation efficiency.

The goal of calibrating the SJRRPGW was to develop a hydrologically reasonable and representative model that provides a good match to observed historic values and is adequate for use in simulations of past and potential future aquifer-system responses to natural and imposed hydrologic stresses.

\section{Calibration Data}

A subset of the approximately 2,800 wells that have recorded groundwater elevations in the study area was selected for model calibration by using the following criteria:

- Availability of construction information for determining the SJRRPGW layer(s) that the well is hydraulically connected to.

- At least 5 years of groundwater-level record.

- At least 15 observations.

On the basis of these criteria, historical data from 133 wells, totaling 10,196 observations, were available for the model calibration. Among measurements from various wells, 78 were inconsistent with the rest of the measurements at those wells and were removed as outliers, resulting in 10,118 observations used for model calibration. For calibration purposes, these observations are treated as independent measurements (though it is likely observations at the same well are correlated). Of the 133 wells, 78 (7,411 observations) were from the DWR or USGS databases, and

55 (2,707 observations) were from the CCID monitoring program. Well construction and other information for the CCID, DWR, and USGS wells are listed in appendix B. The 55 CCID wells are shallow wells on the west side of the San Joaquin River along Reaches 3 and 4A; the median well-screen midpoint for these wells is $12.3 \mathrm{ft}$ below ground surface. The remaining 78 wells are spatially distributed throughout the study area; the median well-screen midpoint for these wells is $198 \mathrm{ft}$ below ground surface. The wells were grouped regionally into seven calibration well groups for the purpose of generating calibration statistics (Fresno, Madera, Mendota, Chowchilla, CCID South, CCID North, and Merced) (fig. 28).

The observations of groundwater elevation were copied into two identical "groups" of data, called "heads" and "drawdown," that were treated differently in the calibration process. For the heads group, the observed values were compared directly to the simulated values. For the drawdown group, the change from one observed value to the initial observed value was compared to the change in the corresponding simulated values. These groups of data were weighted equally. Calibration of the SJRRPGW to values of heads favors accurate simulation of the overall magnitude of groundwater elevations. Calibration to values of drawdown favors accurate simulation of seasonal fluctuations and long-term trends in groundwater elevations. In many circumstances in groundwater models, it is more effective to match drawdowns than to match the heads themselves to achieve the best overall calibration (Hill and others, 2000).

Data from 19 streamgages were used to calibrate the SJRRPGW. Streamflow data are available daily or sub-daily; however, the model stress periods are monthly, so mean monthly observed streamflow values were calculated for comparison with simulated values. Data are not available from all streamgages for the entire simulation period. Monthly averaging and selection of records resulted in 4,695 mean monthly observations for calibration (table 10 and fig. 29). As with the observed groundwater levels, these observations are treated as independent observations, though it is likely that some observations are correlated. The simulated San Joaquin River flow leaving the study area was calibrated using data from the streamgage on the San Joaquin River near Crows Landing, which is 2 river miles downstream from the downgradient (northwest) model boundary.

\section{Calibration Process}

The process of model calibration involves comparison of model output with observed conditions and adjustment of model parameters within reasonable ranges such that simulated conditions adequately represent observed conditions. Prior to calibration, all model parameters were assigned initial values on the basis of previous work in the region (Phillips and others, 2007; Faunt, 2009). 


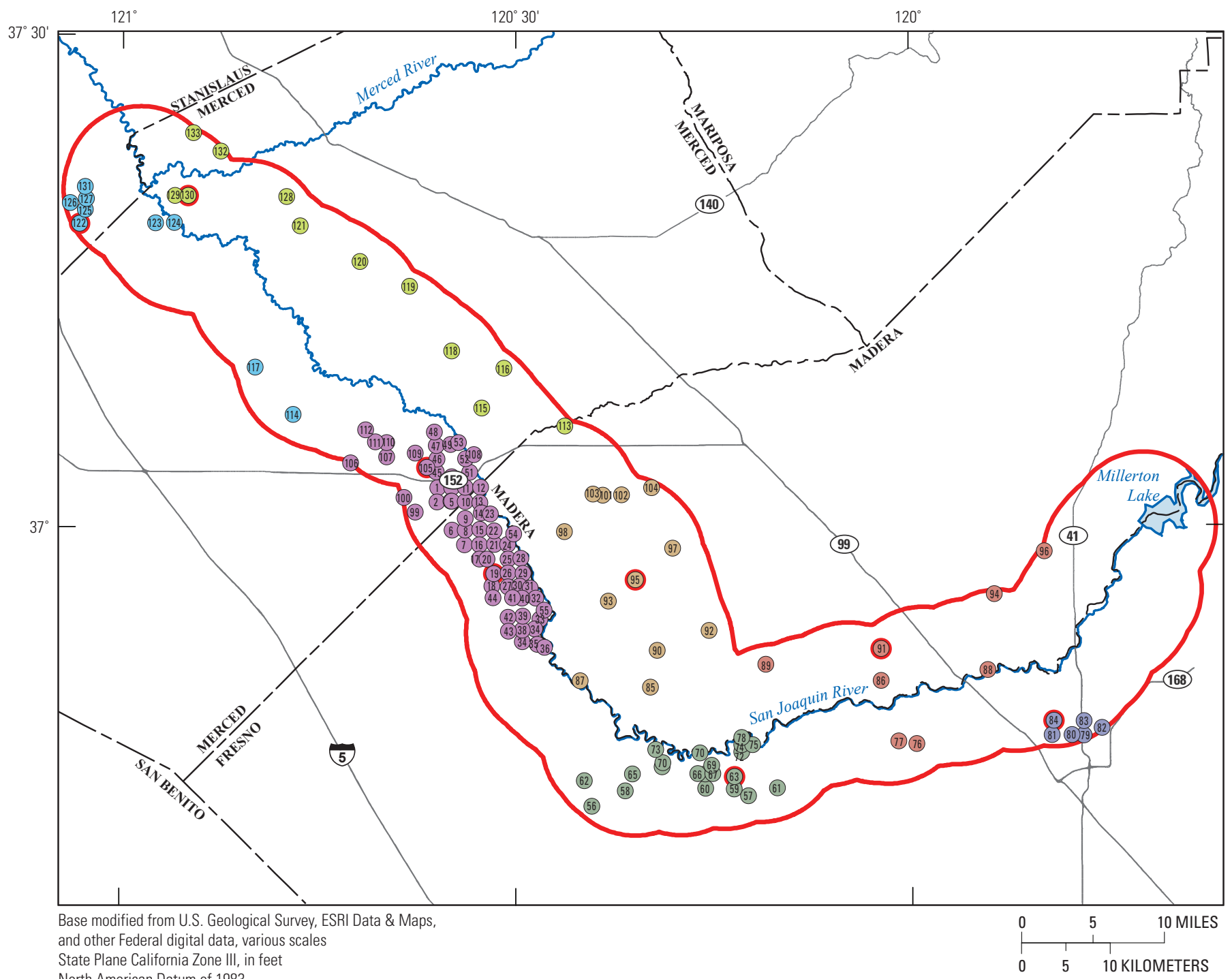

State Plane California Zone III, in feet
North American Datum of 1983

EXPLANATION

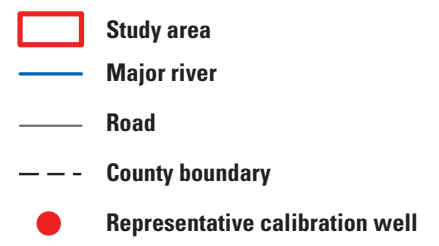
Calibration well group
- Central California Irrigation District north
- Central California Irrigation District south
C Chowchilla
O Merced
Fresno
- Madera
- Mendota
(86) SJRRPGW identification numbers (refer to tables B1 and B2)

Figure 28. Observation wells used in the San Joaquin River Restoration Program groundwater flow model (SJRRPGW) calibration, San Joaquin Valley, California. 
Table 10. Streamgages used in the San Joaquin River Restoration Program groundwater flow model (SJRRPGW) calibration, San Joaquin Valley, California.

[Abbreviations: DWR, Department of Water Resources; mm/yyyy, month/year; USBR, U.S. Bureau of Reclamation; USGS, U.S. Geological Survey]

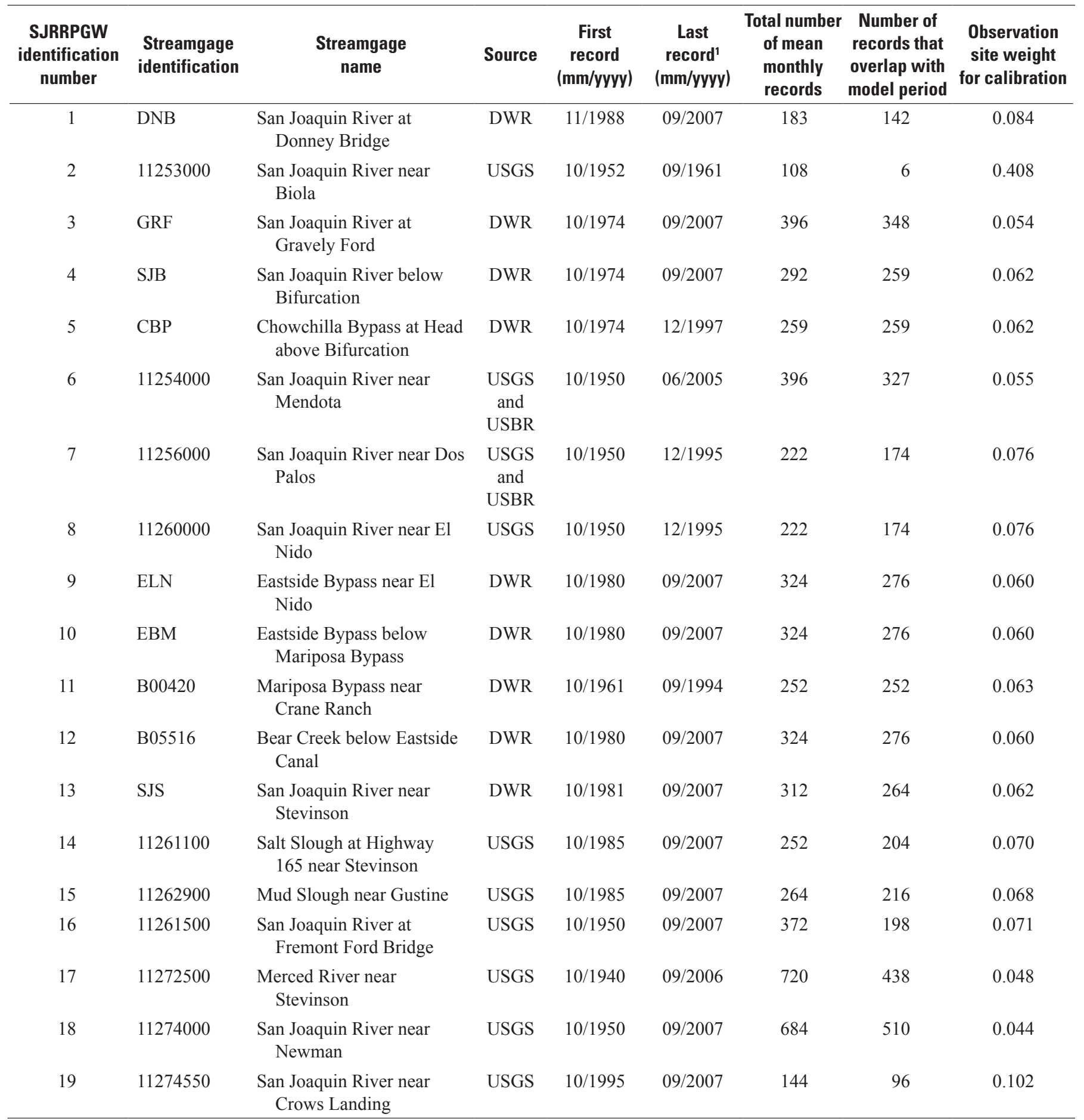

\footnotetext{
${ }^{1}$ As of September 2007
} 


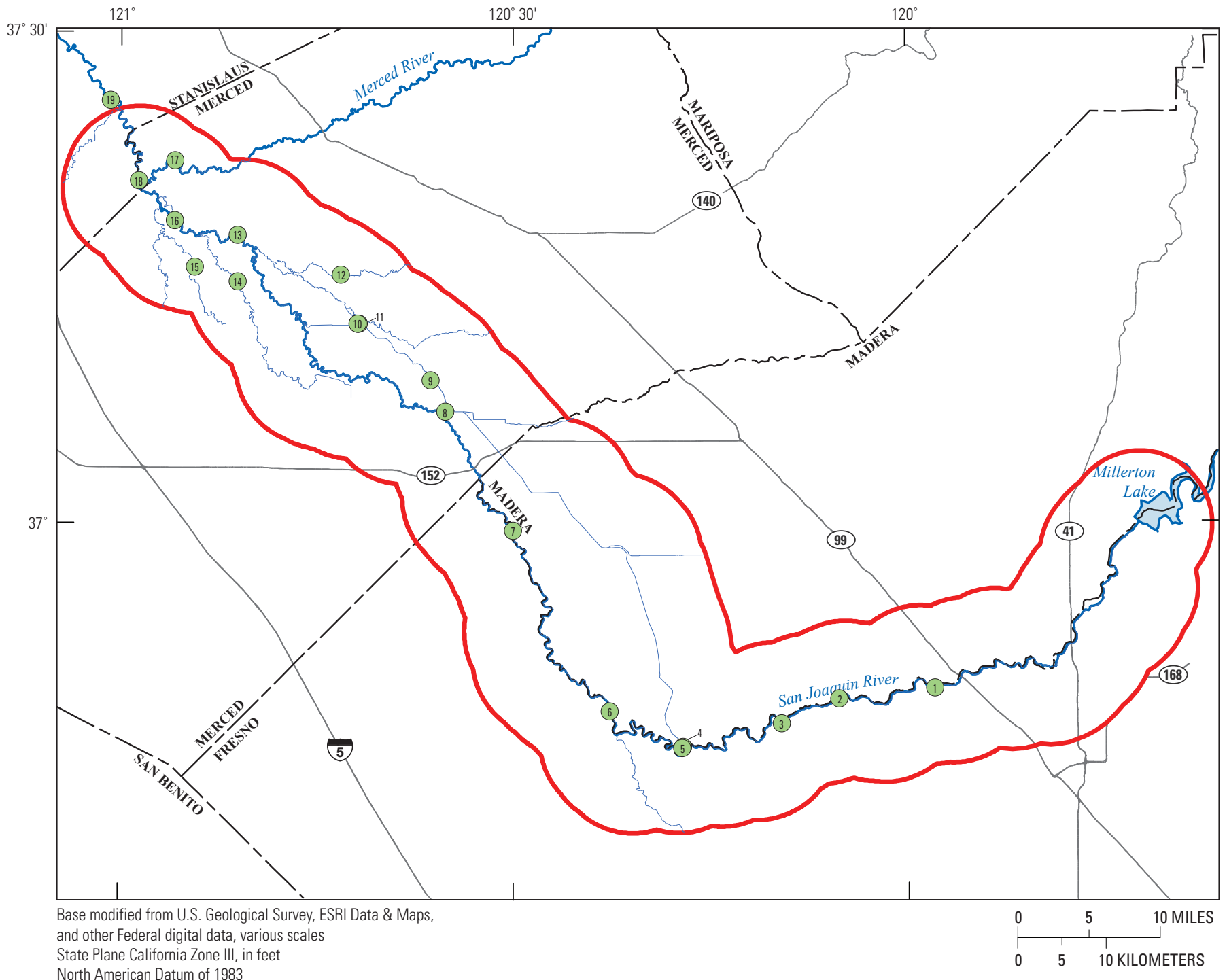

North American Datum of 1983

\section{EXPLANATION}

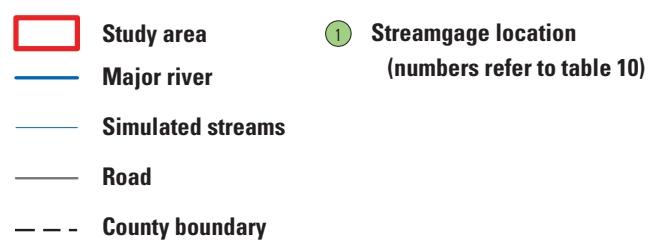

Figure 29. Location of streamgages used in the San Joaquin River Restoration Program groundwater flow model (SJRRPGW) calibration, San Joaquin Valley, California. 
Calibration of the SJRRPGW was accomplished in a semiautomated manner by using a public-domain modelindependent parameter estimation program (PEST) (Doherty, 2005). PEST was run in "estimation mode;" prior information was used to regularize the parameter values. The use of prior information ensures the estimated parameter values fall within a range that makes physical sense. Two types of prior information were used - direct parameter values to regularize individual parameter values and relations between pairs of parameters to regularize ratios between two parameters values (table 11). The relative and overall weighing of the prior information equation was adjusted as needed during calibration to insure the prior information neither dominated nor failed to influence the objective function.

PEST was used to find the parameter set that minimizes the sum of the squared deviations between each observation and its corresponding simulated value (referred to as the "objective function," Doherty, 200) calculated using:

where

$$
\Phi=\sum_{m}\left(\left(h_{m}^{s i m}-h_{m}^{o b s}\right) w_{m}\right)^{2}
$$

$\Phi \quad$ is the objective function that PEST is trying to minimize,

$h_{m}^{o b s} \quad$ is the observed value of observation or prior information $m$,

$h_{m}^{\text {sim }} \quad$ is the simulated value corresponding to observation or prior information $m$,

$w_{m} \quad$ is the weight of the $\mathrm{m}^{\text {th }}$ observation, and

$m \quad$ is the total number of observations and prior information.

A residual is defined as the simulated value at the observation location minus the observed value: $\left(h_{m}^{\text {sim }}-h_{m}^{\text {obs }}\right.$ ). A negative residual means the model is simulating the groundwater elevation or streamflow too low, and a positive residual means the model is simulating the groundwater elevation or streamflow too high.

\section{Parameters Estimated}

Because of the runtime constraint, calibration of all the crop-related parameters was not feasible. During initial parameter estimation runs, SJRRPGW was determined to be most sensitive to the crop coefficients and the irrigation efficiencies and relatively less sensitive to changes in the other crop-related parameters. Therefore, PEST was used to estimate the crop coefficients and irrigation efficiencies, and the remaining crop-related parameters were fixed at the CVHM values.
Crop coefficients and irrigation efficiencies vary monthly in the model and also vary for each subregion. In addition, irrigation efficiencies also varies by crop type. To retain these monthly variations and longer-term trends determined in the CVHM, scale factors were used to calibrate the entire array of crop coefficients for each of the 21 crops and the entire array of irrigation efficiencies for each of the 28 subregions. PEST also was used to estimate the values for 32 hydraulic parameters, including aquifer properties, streambed hydraulic conductivities, and the hydraulic conductivities of the generalhead boundaries. In total, 81 model parameters were calibrated using PEST (table 12). During the calibration process, the 32 hydraulic parameters were log-transformed in order to make the model results vary more linearly with changes in parameter values, which can speed up the parameter estimation process.

\section{Observation Weights}

As discussed previously, groundwater elevations and streamflow observations were used for the PEST calibration. One problem with utilizing both observation types in the calibration process is that streamflows and groundwater elevations are of vastly different magnitudes. For example, because the model units are in $\mathrm{ft}$ and days, a typical streamflow observation is 86 million cubic $\mathrm{ft}$ per day $\left(\mathrm{ft}^{3} / \mathrm{d}\right.$, or approximately $1,000 \mathrm{ft}^{3} / \mathrm{s}$ ), and a typical groundwater elevation is $100 \mathrm{ft}$. Without weighting, a small difference between an observed and simulated streamflow of $870,000 \mathrm{ft}^{3} / \mathrm{d}$ (approximately $1 \mathrm{ft}^{3} / \mathrm{s}$ ) would be "seen by PEST" as being equivalent to a change of $870,000 \mathrm{ft}$ in groundwater elevation.

In order to overcome this unit discrepancy, all the differences between observed and simulated streamflow were weighted such that they represented a percentage change rather than an absolute change. The weights were set so that a 5-percent difference between simulated and observed streamflow would be "seen by PEST" as equivalent to a 1-ft difference between simulated and observed groundwater elevation. For streamflow observations below $100 \mathrm{ft}^{3} / \mathrm{s}$, it was assumed the flow was $100 \mathrm{ft}^{3} / \mathrm{s}$ for the purpose of calculating the weight. For example, if the observed flow was $0 \mathrm{ft}^{3} / \mathrm{s}$ and the simulated flow was $50 \mathrm{ft}^{3} / \mathrm{s}$, the difference would be "seen by PEST" as 50 percent.

Because the number of observations at each site varies and in order to prevent sites with a lot of observations from dominating the calibration process, sites with fewer observations were given additional weight so that the weights for individual sites were spatially consistent. The overall weight at each site is shown for streamgages in table 10 and for groundwater wells in appendix B. The overall weight at each observation, which is a product of the site weight and the unit discrepancy weight, is contained in the PEST control file, available in the model files. 


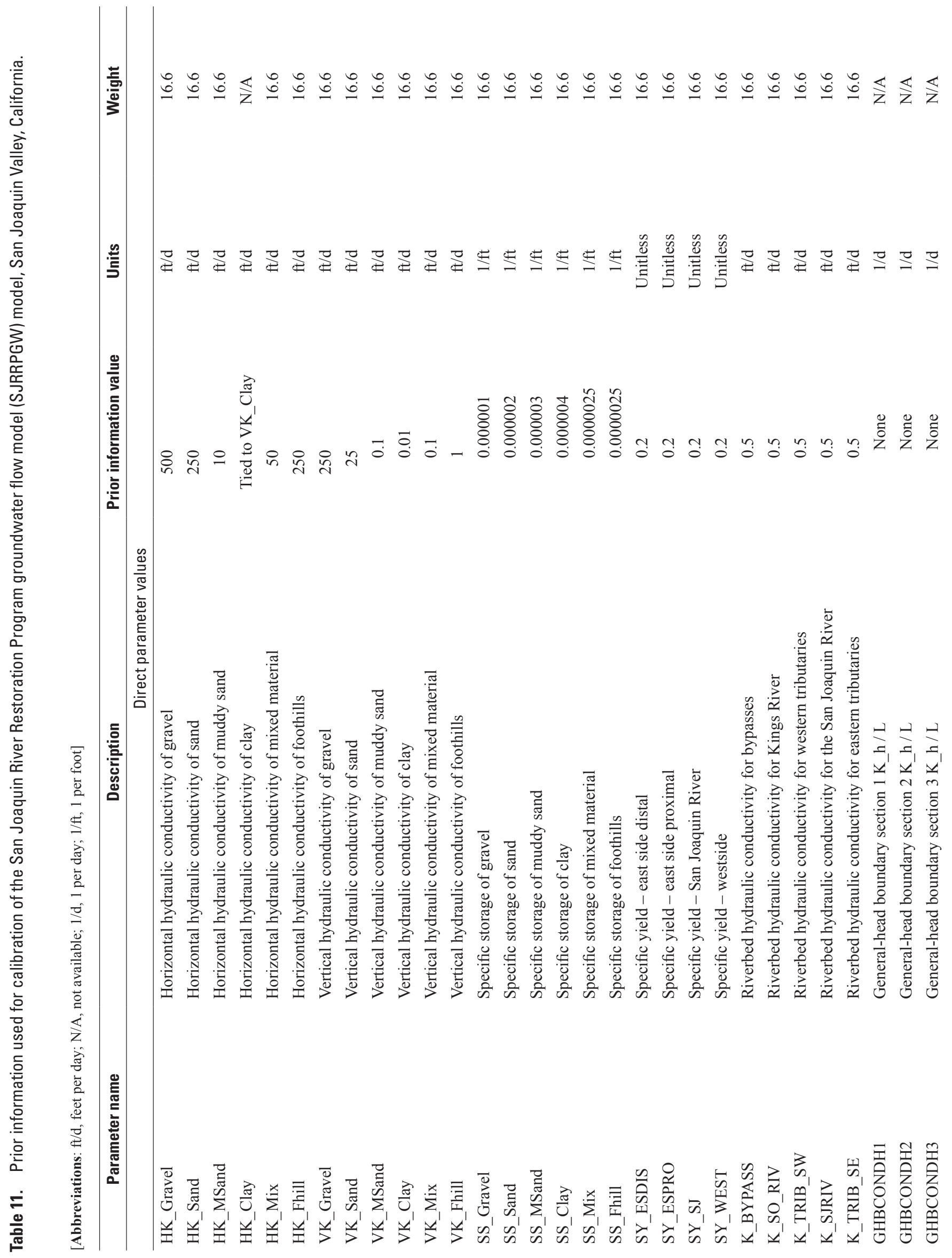


:

(1) 


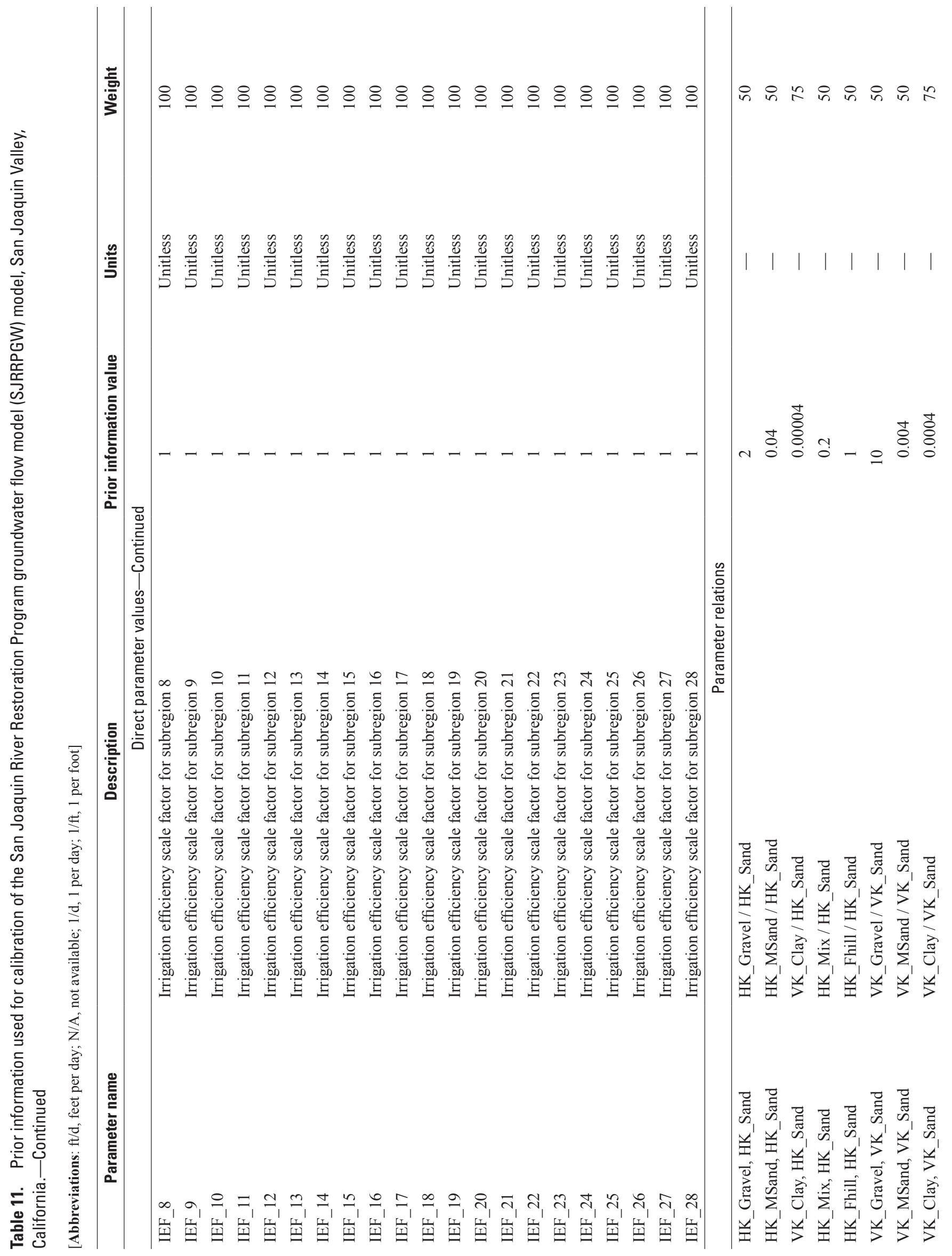




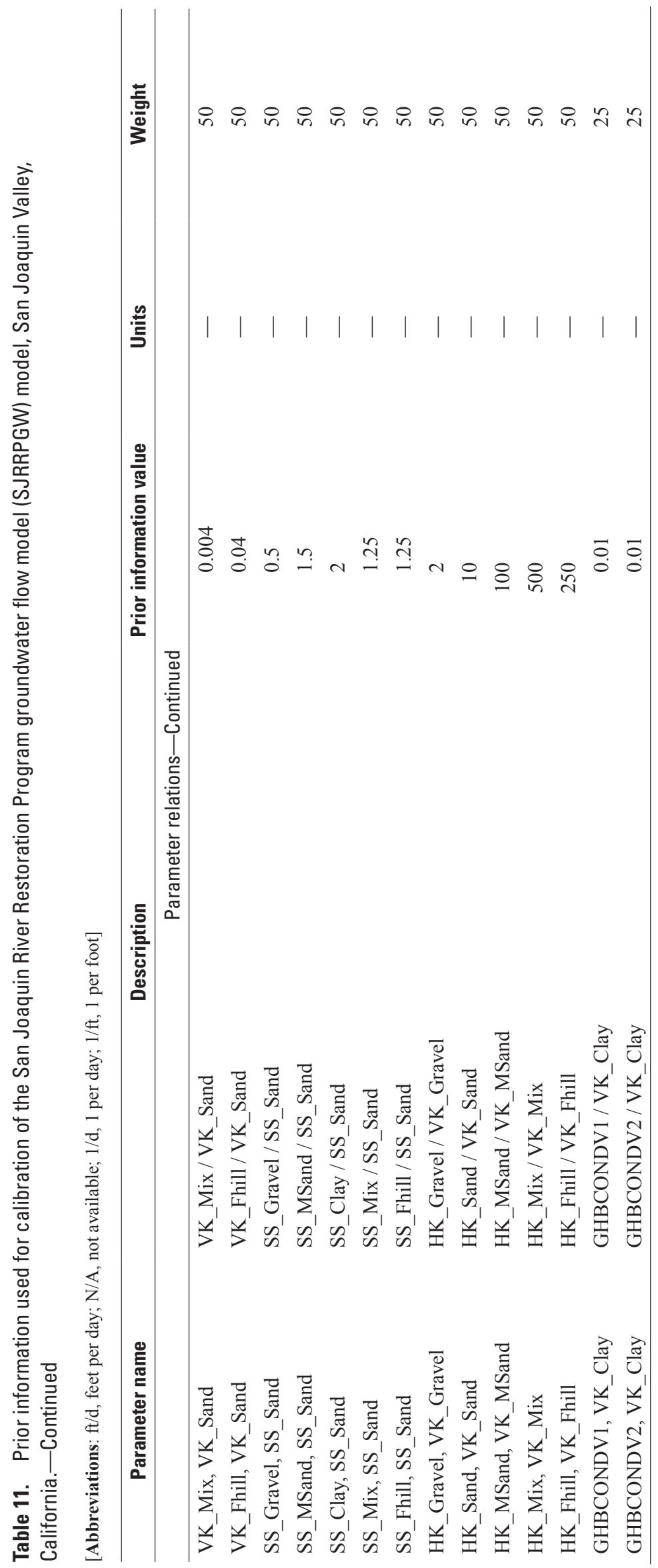




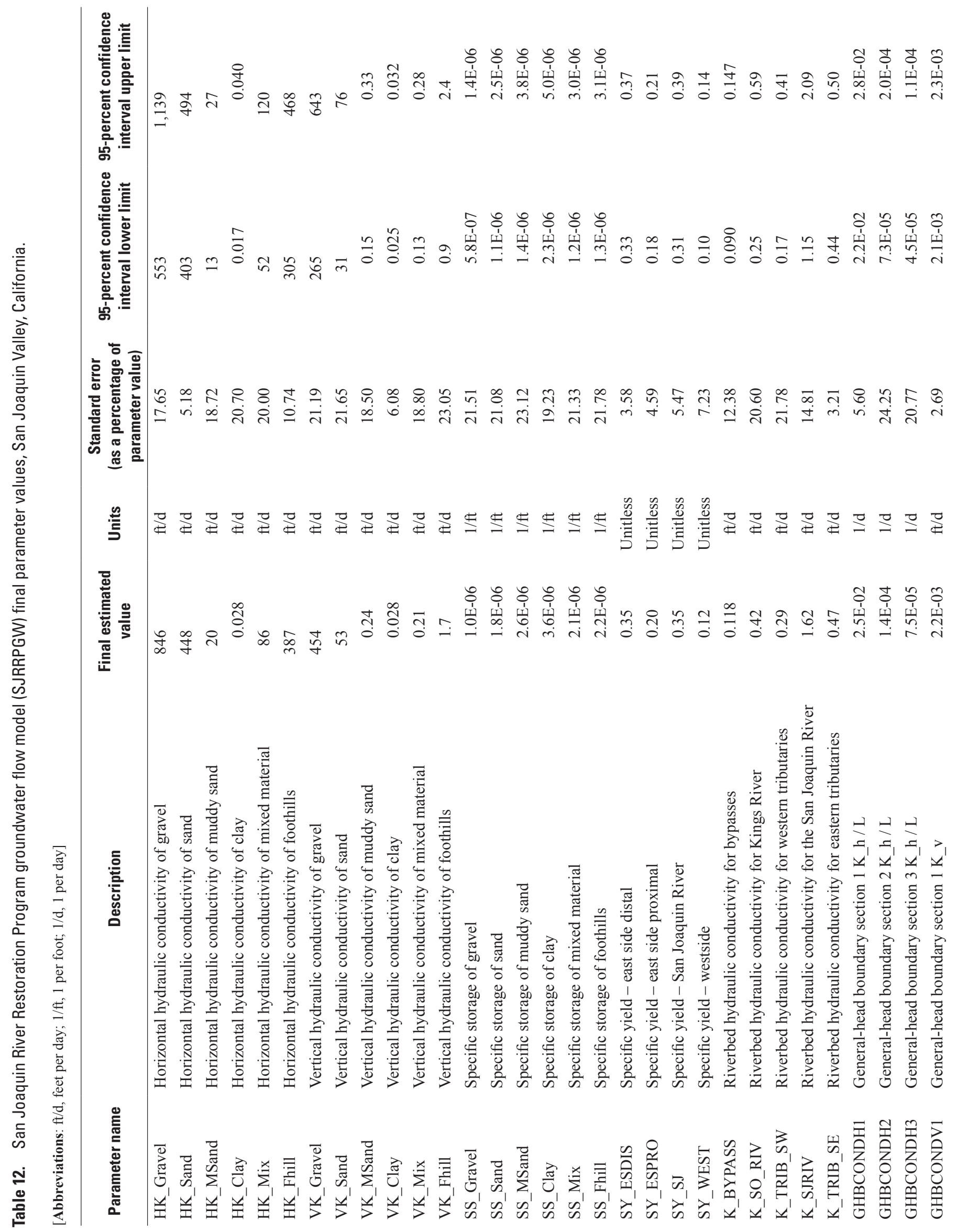




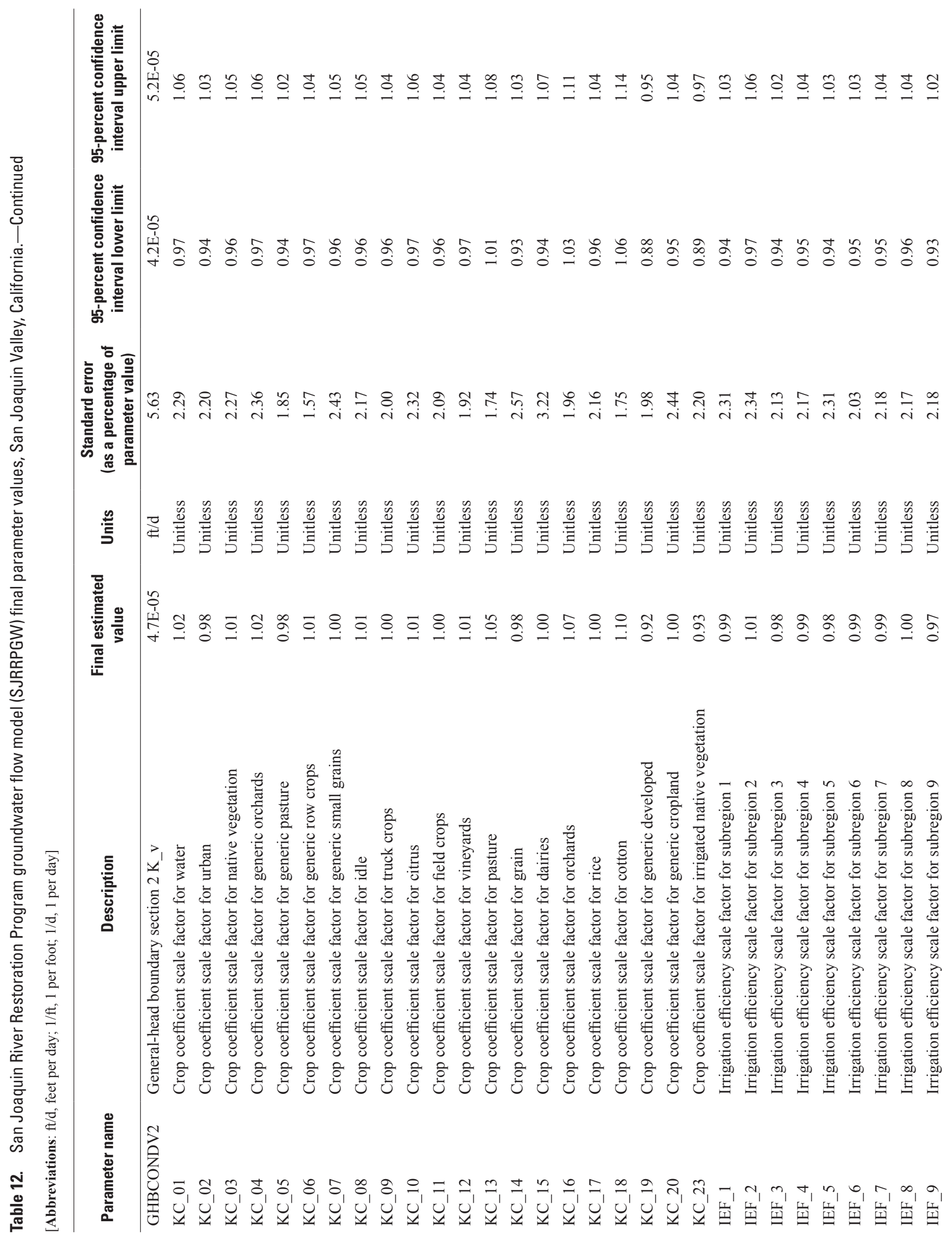




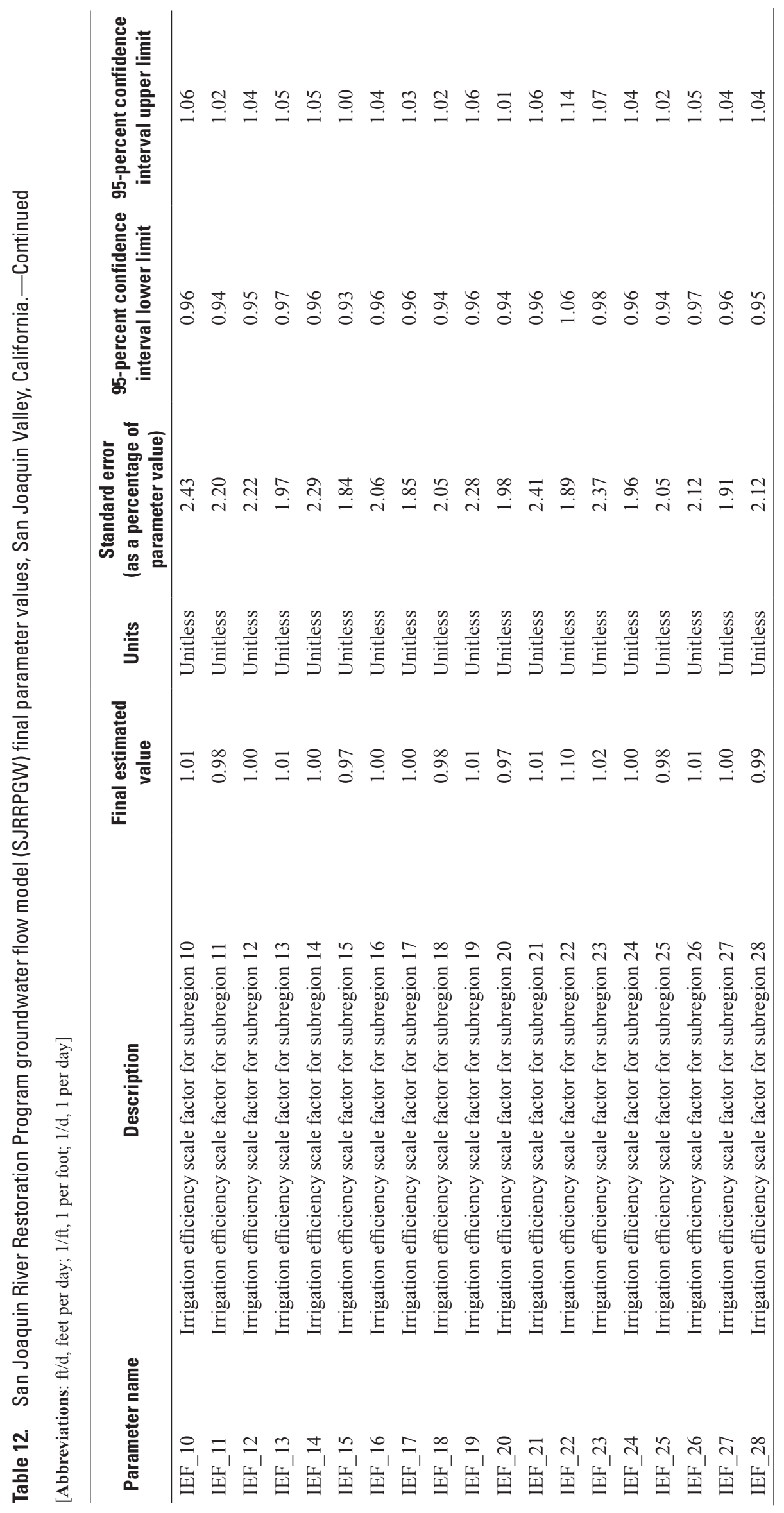




\section{Calibration Results}

Calibration of the SJRRPGW model using the procedure described above resulted in a set of parameter estimates that lie within the range of reasonable values (table 12). The estimated horizontal and vertical hydraulic conductivities are generally consistent with parameters from similar studies in the greater San Joaquin region (Phillips and others, 2007; Burow and others, 2008) (table 13). Differences between the three studies can be explained by how each study defines the texture groups. In Phillips and others (2007), sand and gravel are lumped into the most coarse category (resulting in 21 percent of Pleistocene deposits and 31 percent of Holocene deposits classified as the most coarse) leading to a lower calibrated hydraulic conductivity value of $260 \mathrm{ft} / \mathrm{d}$ for this category. In Burow and others (2008), the most coarse category only includes cobbles and pebbles (resulting in only 1 percent of the deposits being classified as the most coarse) leading to a higher calibrated hydraulic conductivity value of $2,600 \mathrm{ft} / \mathrm{d}$ for this category. In this study, the definition of the most coarse category takes a moderate approach (resulting in 4 percent of the deposits being classified as the most coarse) leading to a calibrated hydraulic conductivity value of $840 \mathrm{ft} / \mathrm{d}$ that lies between the values from the previous two studies. A similar pattern is also seen with the other aquifer texture categories across the three studies.

The general-head boundary hydraulic conductivity values are highest along the western boundary of the model (GHBCONDH1) and lowest in the Fresno area (GHBCONDH3), which is rooted in the local performance of the CVHM in these areas. Higher conductance values result in a stronger connection between the CVHM and SJRRPGW where the boundary heads in the CVHM matched observed values, and lower conductance values result in a weaker connection where the match between observed heads and the CVHM simulated heads was poor. The calibrated scale factors on the crop coefficients and irrigation efficiencies are between 0.92 and 1.10, resulting in parameter values that are less than 10 percent different than those used in the CVHM.

\section{Model Fit to Observations of Groundwater Elevations}

To quantify the model fit between the simulated and observed groundwater elevations for all 10,118 observations at the 133 calibration target wells, the histogram of residuals was examined (fig. 30A). The residuals (fig. 30A) range from -56 to $91 \mathrm{ft}$ and have a mean of $-0.6 \mathrm{ft}$, an absolute mean of $9.0 \mathrm{ft}$, a standard deviation of $12 \mathrm{ft}$, a skewness of 0.5 , and an excess kurtosis of 3.0. The mean value of $-0.6 \mathrm{ft}$ indicates very little bias, or preferentially high or low simulated heads, and the absolute mean of $9.0 \mathrm{ft}$ indicates good model fit for a region of this scale. The relatively low absolute values of skewness and excess kurtosis indicate the residuals are normally distributed around zero. Approximately 64 percent of the SJRRPGW simulated values fall within $10 \mathrm{ft}$ of the observed values and about 92 percent fall within $20 \mathrm{ft}$. These residuals are within the calibration targets for a regional model of this scale.

The relation between observed and simulated groundwater elevations provides another means to quantify the model fit (fig. 30B). Points that plot above and below the 1-to-1 correlation line represent observations where the SJRRPGW is simulating groundwater elevations too high and too low, respectively. Most of the points are very close to the 1-to-1 correlation line, indicating a good model fit. Outliers removed early in the calibration process also are shown on figure $30 B$; these outliers are not included in the model-fit or other statistics presented in this report. The correlation at some individual wells can be seen in figure $30 \mathrm{~B}$. For example, the points from the Madera dataset that have an observed value near $100 \mathrm{ft}$ and a simulated value close to $180 \mathrm{ft}$ are from calibration well 94, where the long-term declining groundwater levels are not being simulated well by the SJRRPGW model because of the effects of boundary conditions.

The relation between residual and observed groundwater elevations is a third method for quantifying the model fit (fig. 30C). This figure shows the model generally simulates lower groundwater elevations too high and higher groundwater elevations too low.

Table 13. Comparison of San Joaquin River Restoration Program groundwater flow model (SJRRPGW) parameter values to values in similar studies, San Joaquin Valley, California.

[Abbreviations: $\mathrm{ft} / \mathrm{d}$, feet per day]

\begin{tabular}{|c|c|c|c|c|c|c|c|c|}
\hline \multirow[b]{2}{*}{ Source } & \multicolumn{4}{|c|}{ Horizontal hydraulic conductivity } & \multicolumn{4}{|c|}{ Vertical hydraulic conductivity } \\
\hline & $\begin{array}{c}\text { Gravel/ } \\
\text { sand } \\
\text { (ft/d) }\end{array}$ & $\begin{array}{c}\text { Sand/silty } \\
\text { sand } \\
\text { (ft/d) }\end{array}$ & $\begin{array}{l}\text { Muddy sand/silt } \\
\qquad(\mathrm{ft} / \mathrm{d})\end{array}$ & $\begin{array}{l}\text { Clay } \\
\text { (ft/d) }\end{array}$ & $\begin{array}{c}\text { Gravel/ } \\
\text { sand } \\
\text { (ft/d) }\end{array}$ & $\begin{array}{c}\text { Sand/silty } \\
\text { sand } \\
\text { (ft/d) }\end{array}$ & $\begin{array}{l}\text { Muddy sand/silt } \\
\text { (ft/d) }\end{array}$ & $\begin{array}{l}\text { Clay } \\
(\mathrm{ft} / \mathrm{d})\end{array}$ \\
\hline SJRRPGW simulated values & 840 & 450 & 20 & 0.028 & 450 & 53 & 0.24 & 0.028 \\
\hline Burrow and others, 2008 & 2,600 & 320 & 7.2 & 0.0033 & 2,400 & 150 & 3.6 & 0.010 \\
\hline
\end{tabular}



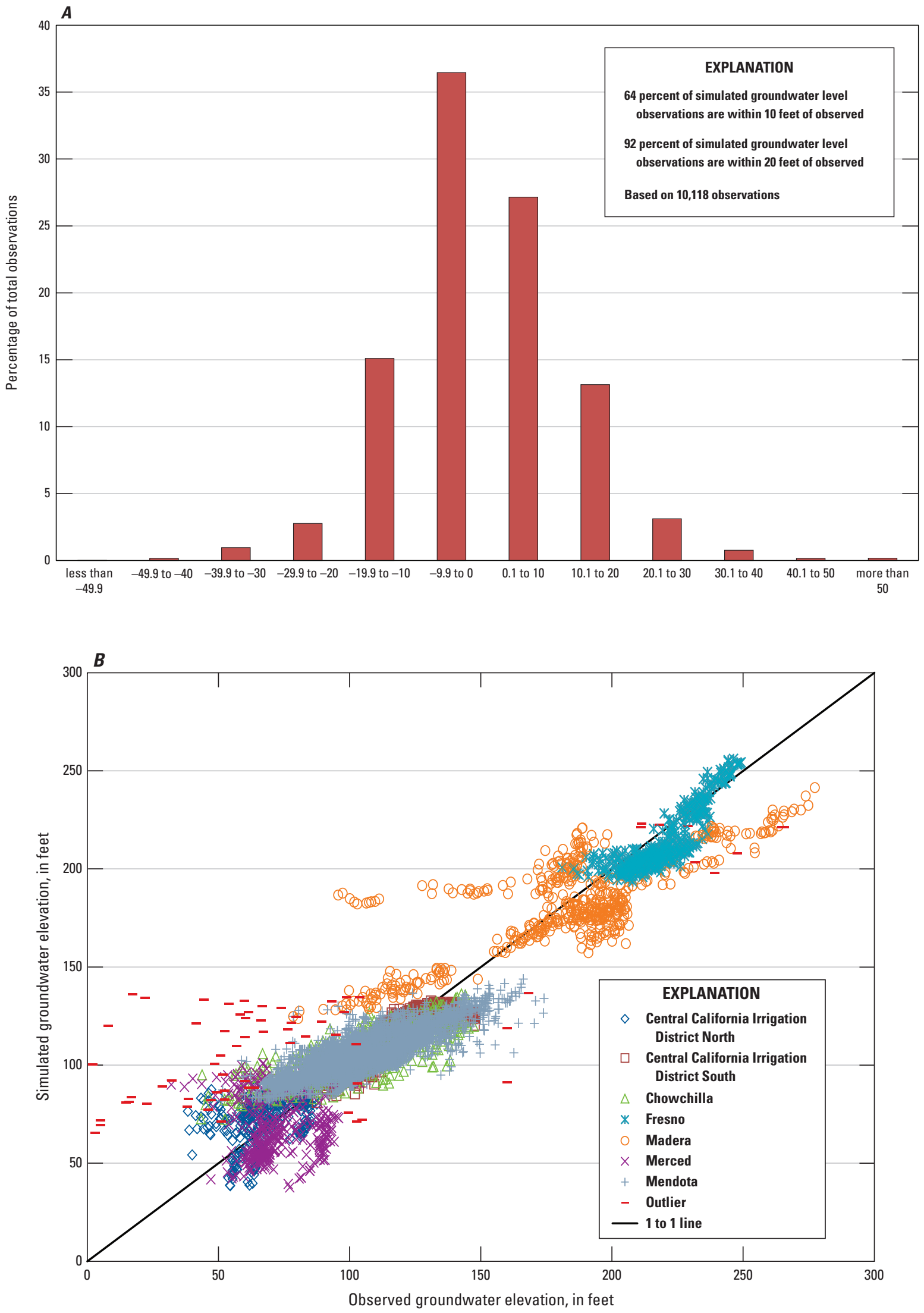

Figure 30. Relation between simulated and observed groundwater elevations: $A$, Histogram of residual groundwater elevations; $B$, Simulated and observed groundwater elevations; $C$, Residual and observed groundwater elevations. 


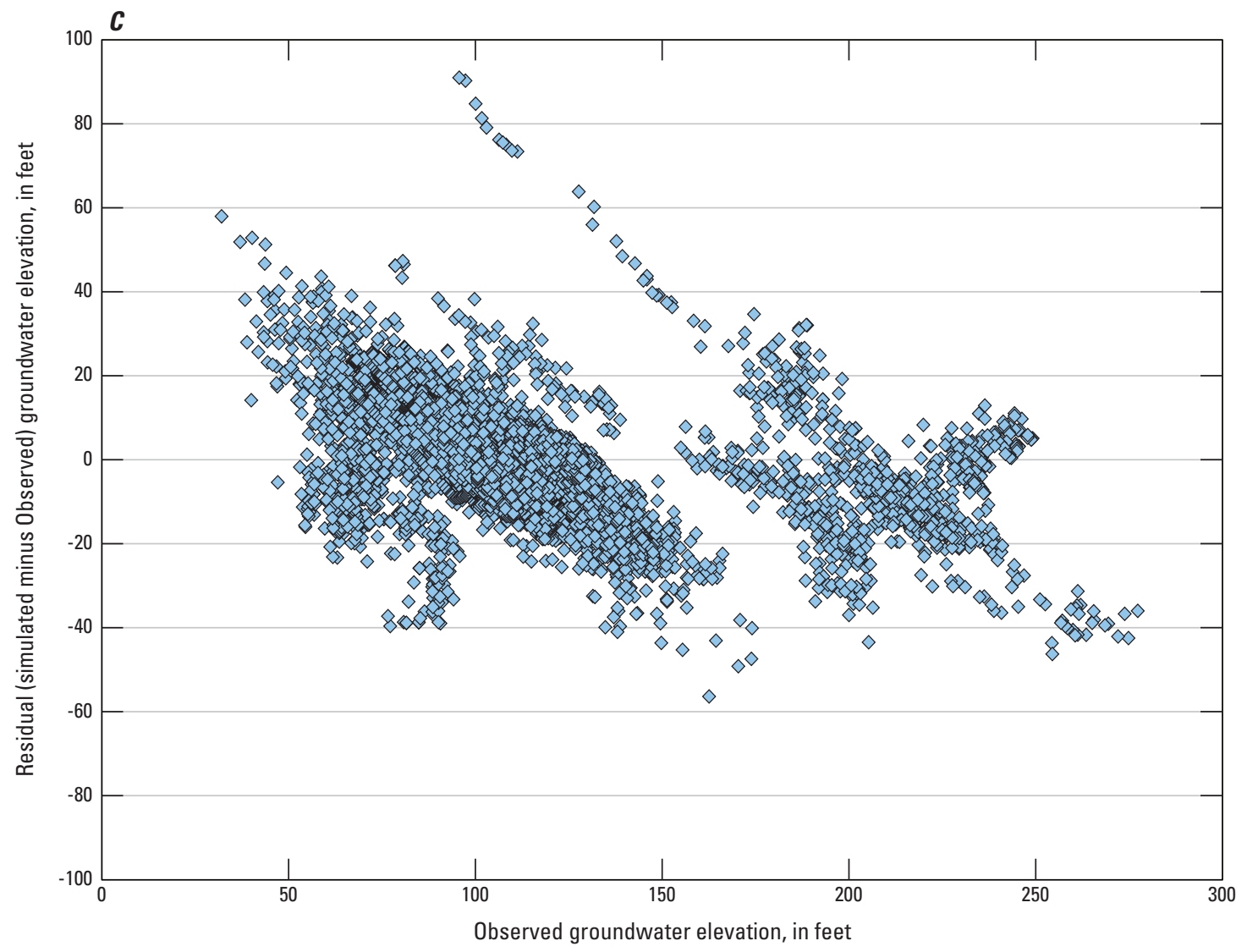

Figure 30. - Continued 
It is important that there is no spatial bias in the residuals that might indicate local processes not being simulated correctly. Average residuals for each observation well show the high and low residuals are not spatially clustered (fig. 31). Plots comparing the simulated and observed time series of groundwater elevations at eight representative calibration wells are presented in the next section of this report. The relations between simulated and observed groundwater elevations at all 133 calibration wells are presented in appendix C.

\section{Groundwater Elevations at Representative Calibration Wells}

A total of eight representative calibration wells are presented in this section of the report (fig. $32 A-H$ ). One well was selected for each of the seven calibration well groups; two wells were selected for CCID South (one deep well and one shallow well). The hydrographs for these wells (fig. 32) show the observed groundwater elevations with points and the simulated groundwater elevations with lines. Simulated groundwater elevations are shown for model layers that correspond to where the wells are screened.

The hydrograph for calibration well 84 $(13 \mathrm{~S} 20 \mathrm{E} 17 \mathrm{~F} 001 \mathrm{M})$ is representative of the Fresno calibration well group (fig. 32A). Although the SJRRPGW simulates groundwater elevation on average $6 \mathrm{ft}$ too high in the Fresno area, the model reasonably simulates the decline in groundwater elevations over time caused by municipal pumping. The Fresno area has a total of 501 observations; 98 percent of them are simulated within $\pm 20 \mathrm{ft}$.

The hydrograph for calibration well 91 $(12 \mathrm{~S} 18 \mathrm{E} 19 \mathrm{H} 001 \mathrm{M})$ is representative of the Madera calibration well group (fig. 32B). Although the simulation at well 91 tends to underestimate the groundwater elevation, the SJRRPGW simulates groundwater elevation on average $1 \mathrm{ft}$ too high in the Madera area; however, there is a large range in the residuals. Only 54 percent of the 514 observations were simulated within $\pm 20 \mathrm{ft}$. The relatively poor performance of the model in the Madera area is partly because of the influence of the CVHM-based boundary condition to the north and also to a large variation in groundwater levels and trends at neighboring wells. Despite the enhanced refinement of this model, the local variability in conditions and site-specific response to real pumping cannot be captured because the model distributes pumping evenly throughout each subregion. At calibration well 91, the observed seasonal variability and overall trend are well simulated. Simulated heads also respond to drought conditions in 1976-77 and 1987-92, although the recovery during wet conditions is less than observed.

The hydrograph for calibration well 63 $(14 \mathrm{~S} 16 \mathrm{E} 04 \mathrm{~A} 001 \mathrm{M})$ is representative of the Mendota calibration well group (fig. 32C). The Mendota area had the most data (4,602 observations) of any of the calibration areas. On average, the SJRRPGW simulates groundwater elevations $1 \mathrm{ft}$ too high; 93 percent of the simulated values were within $\pm 20 \mathrm{ft}$ of the observations. Wells in the Mendota area show a larger seasonal fluctuation in groundwater elevations than wells in the rest of the study area, but the SJRRPGW simulates these seasonal and longer-term fluctuations reasonably well.

The hydrograph for calibration well 95 (11S15E29H001M) is representative of the Chowchilla calibration well group (fig. 32D). Many wells in the Chowchilla area show a long-term decline in groundwater elevation with episodic recovery during wetter periods in the early 1980s and mid-1990s. Although the model reasonably matches the shape and timing of these trends, it does not reach the same magnitude in either the observed decline or the maximum recovery. It is possible some of the observations represent pumping conditions, which are not fully captured at the temporal and spatial scale of the SJRRPGW. Despite this limitation, the model performs acceptably well in the Chowchilla area; the average residual is $1 \mathrm{ft}$. The Chowchilla area has a total of 591 observations, 85 percent of which are simulated within $\pm 20 \mathrm{ft}$.

For the CCID South calibration well group, two wells are presented - the hydrograph for calibration well 19 (CCID140), which is representative of the water table (fig. $32 E$ ), and the hydrograph for calibration well 105 (10S12E13L001M), which is representative of deeper conditions (fig. $32 F$ ). The SJRRPGW performs exceptionally well in the CCID South area, which is attributed to accurate CVHM boundary conditions to the west and a large set of calibration wells from the CCID monitoring wells program. This area also has a comparatively small range of fluctuations in the observed groundwater elevations compared to other regions. The performance of the SJRRPGW in this area is relatively important because the CCID South calibration area is adjacent to SJRRP management Reaches 3 and $4 \mathrm{a}$, which are areas underlain by a shallow water table. The CCID South area has a total of 3,200 observations. The average residual is $-2 \mathrm{ft}$, and 96 percent of the observations are simulated within $\pm 10 \mathrm{ft}$ (99 percent within $\pm 20 \mathrm{ft}$ ).

The hydrograph for calibration well 130 $(07 \mathrm{~S} 10 \mathrm{E} 07 \mathrm{~L} 001 \mathrm{M})$ is representative of the Merced calibration well group (fig. $32 G$ ). On average, the SJRRPGW simulates groundwater elevations $5 \mathrm{ft}$ too low in the Merced area. One difficulty in calibration of the Merced area is that most observation wells had only sparse data. Despite this limitation, the model simulates groundwater elevations in this area reasonably well; 70 percent of the 365 observations are simulated within $\pm 20 \mathrm{ft}$.

The hydrograph for calibration well 122 $(07 \mathrm{~S} 08 \mathrm{E} 23 \mathrm{R} 001 \mathrm{M})$ is representative of the CCID North calibration well group (fig. $32 H$ ). This area includes many of the wildlife management areas (fig. 19) in the study area, which do not have any observation wells to use for calibration. Thus, this calibration area has only 345 observations, the least of any area. Despite this lack of data, the SJRRPGW reasonably matches the groundwater elevations, although it overestimates groundwater elevations after 1980. On average, the SJRRPGW simulates groundwater elevations in the CCID North area $5 \mathrm{ft}$ too high, and 89 percent of the observations are simulated within $\pm 20 \mathrm{ft}$. 


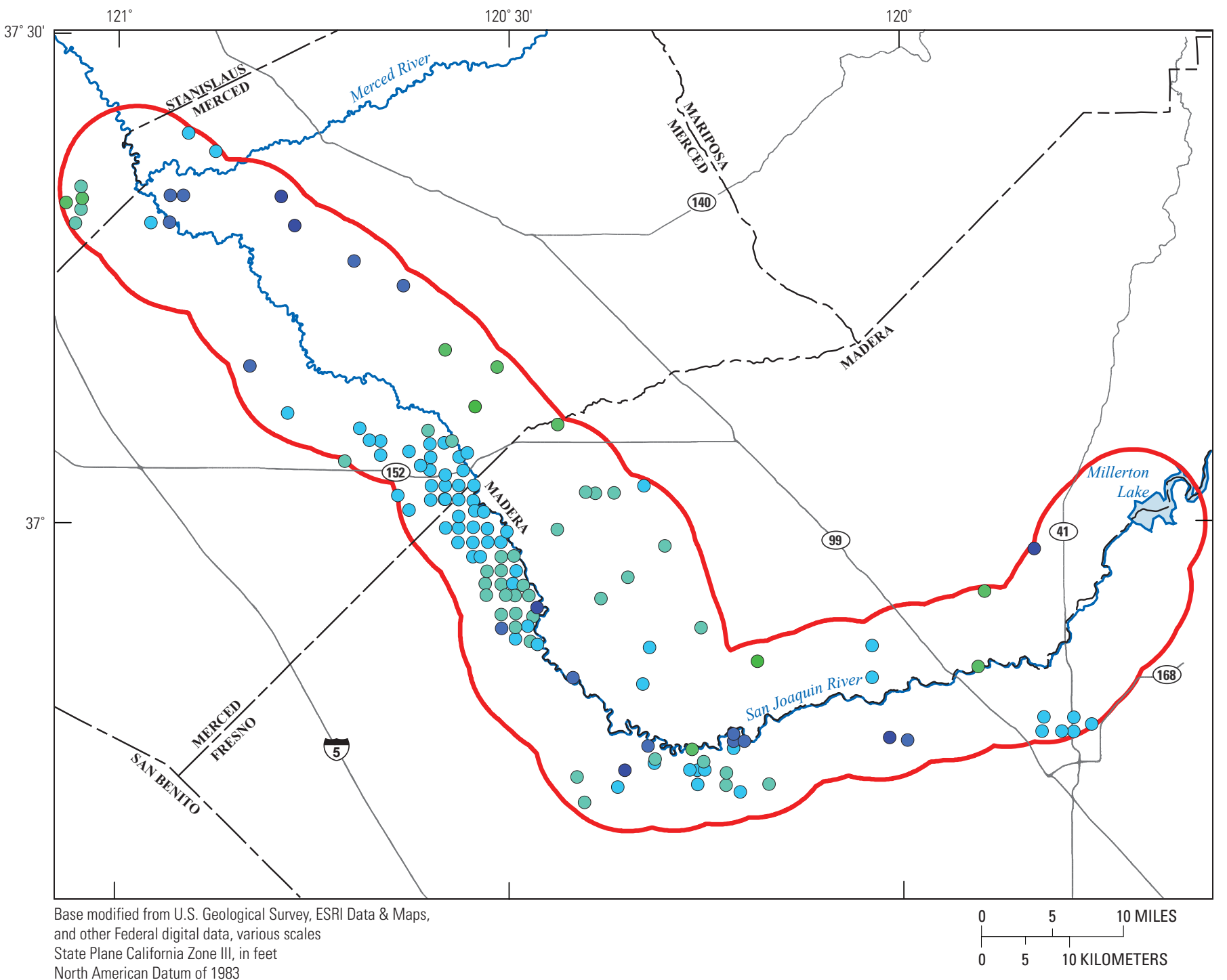

EXPLANATION

\begin{tabular}{ll}
$\square$ Study area & Average residual, in feet \\
\hline Major river & less than -20 \\
- Road & $\bigcirc-20$ to $<-10$ \\
-- County boundary & $\bigcirc-10$ to $<0$ \\
& $\bigcirc 0$ to $<10$ \\
& 10 to $<20$ \\
& more than 20
\end{tabular}

Figure 31. Average residual (simulated - observed) groundwater elevation at observation wells used in the San Joaquin River Restoration Program groundwater flow model (SJRRPGW) calibration, San Joaquin Valley, California. 

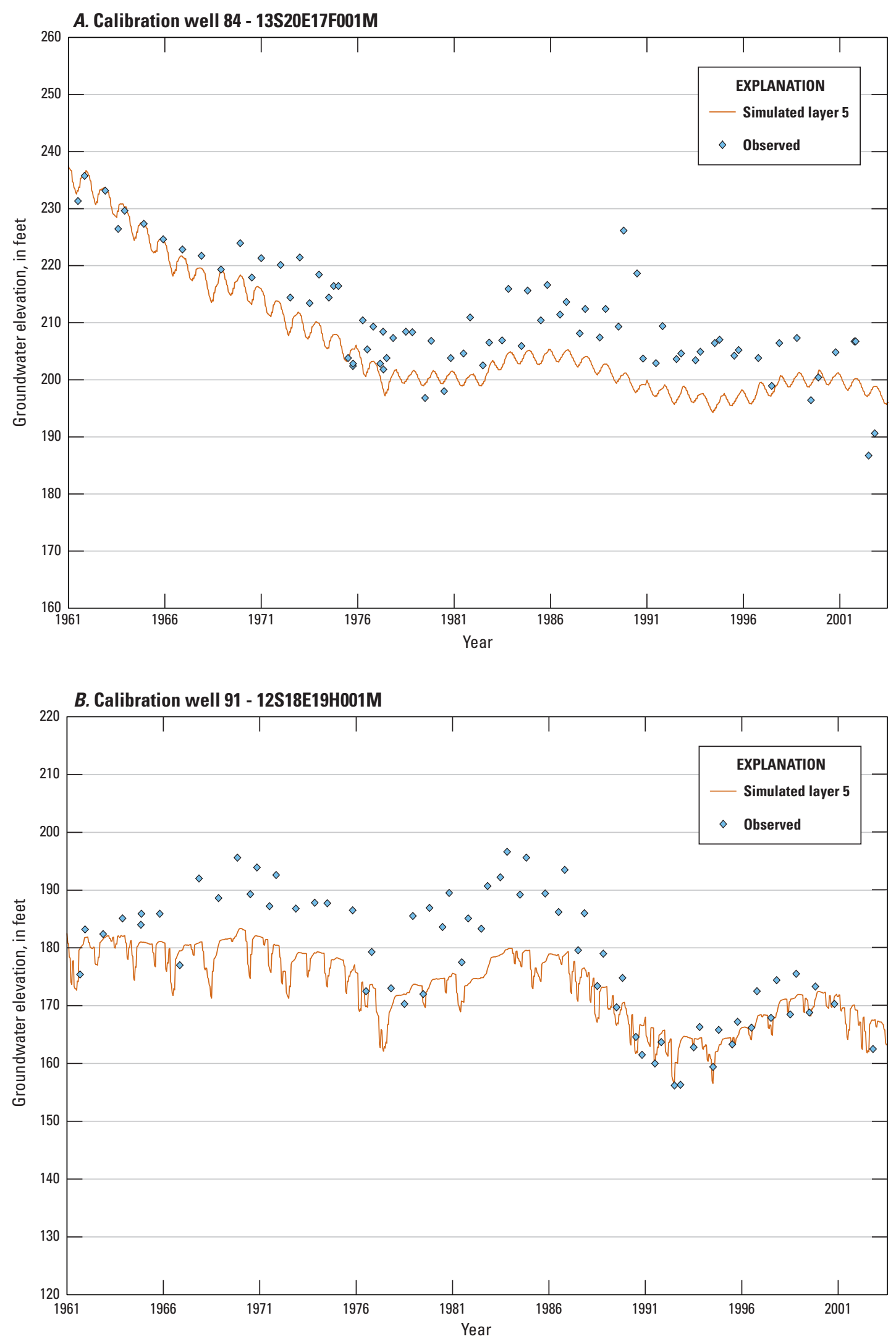

Figure 32. Representative hydrographs for each San Joaquin River Restoration Program groundwater flow model (SJRRPGW) calibration area comparing simulated and observed groundwater elevations, San Joaquin Valley, California: $A$, Fresno; $B$, Madera Area; $C$, Mendota; D, Chowchilla; $E$, Central California Irrigation District (CCID) South - shallow; F, CCID South - deep; G, Merced; H, CCID North. 
C. Calibration well 63 - 14S16E04A001M

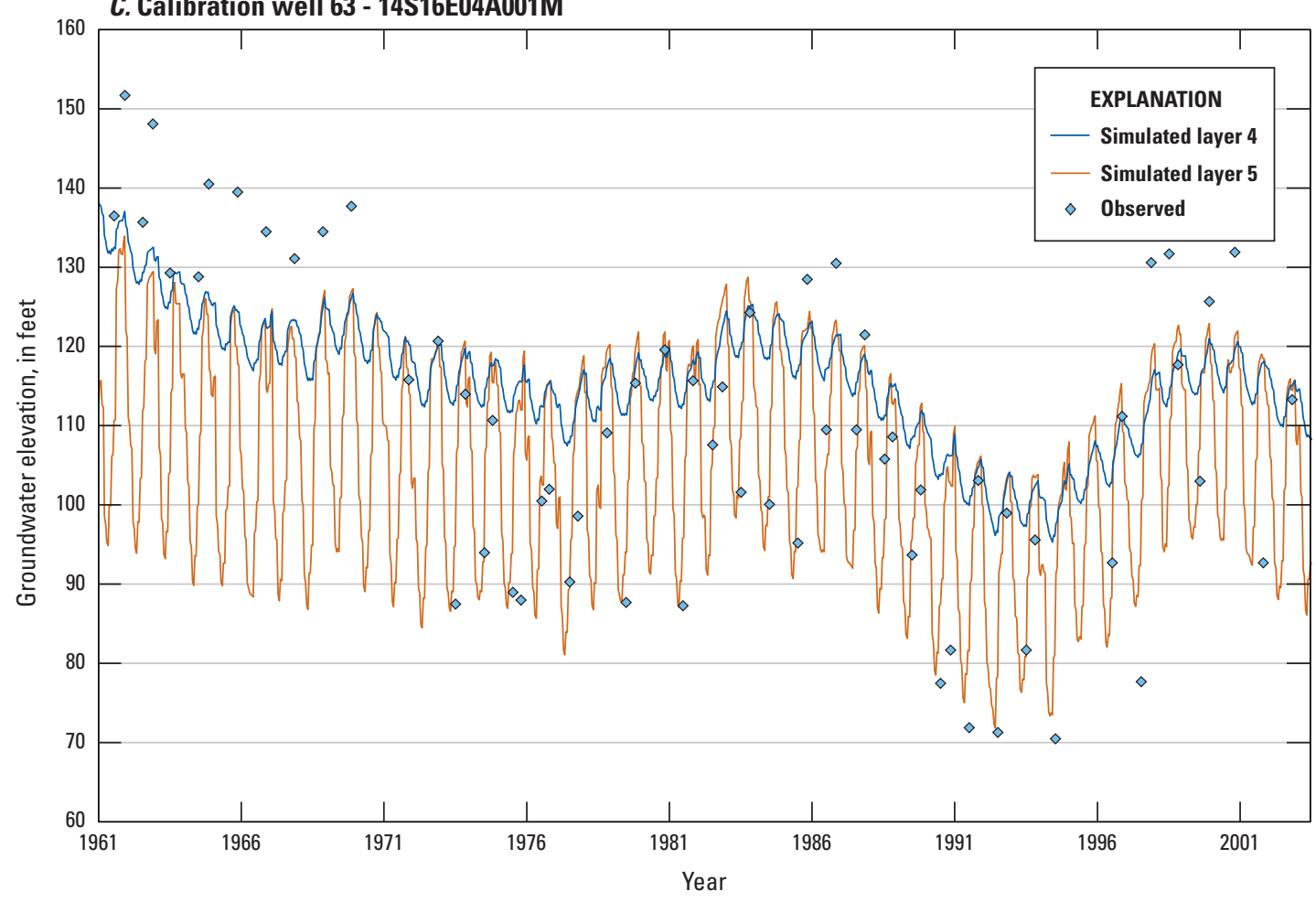

D. Calibration well 95 - 11S15E29H001M

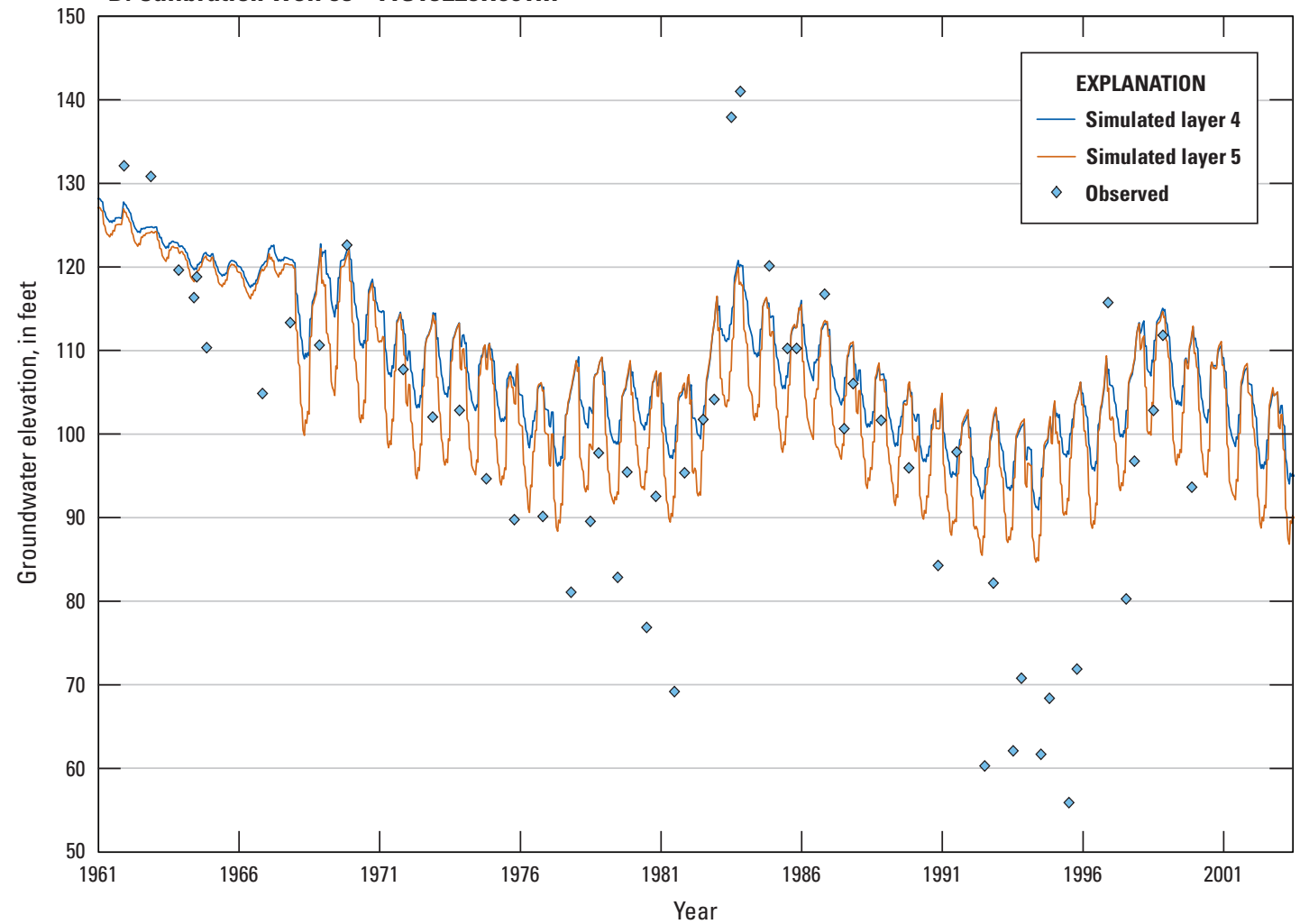

Figure 32. - Continued. 

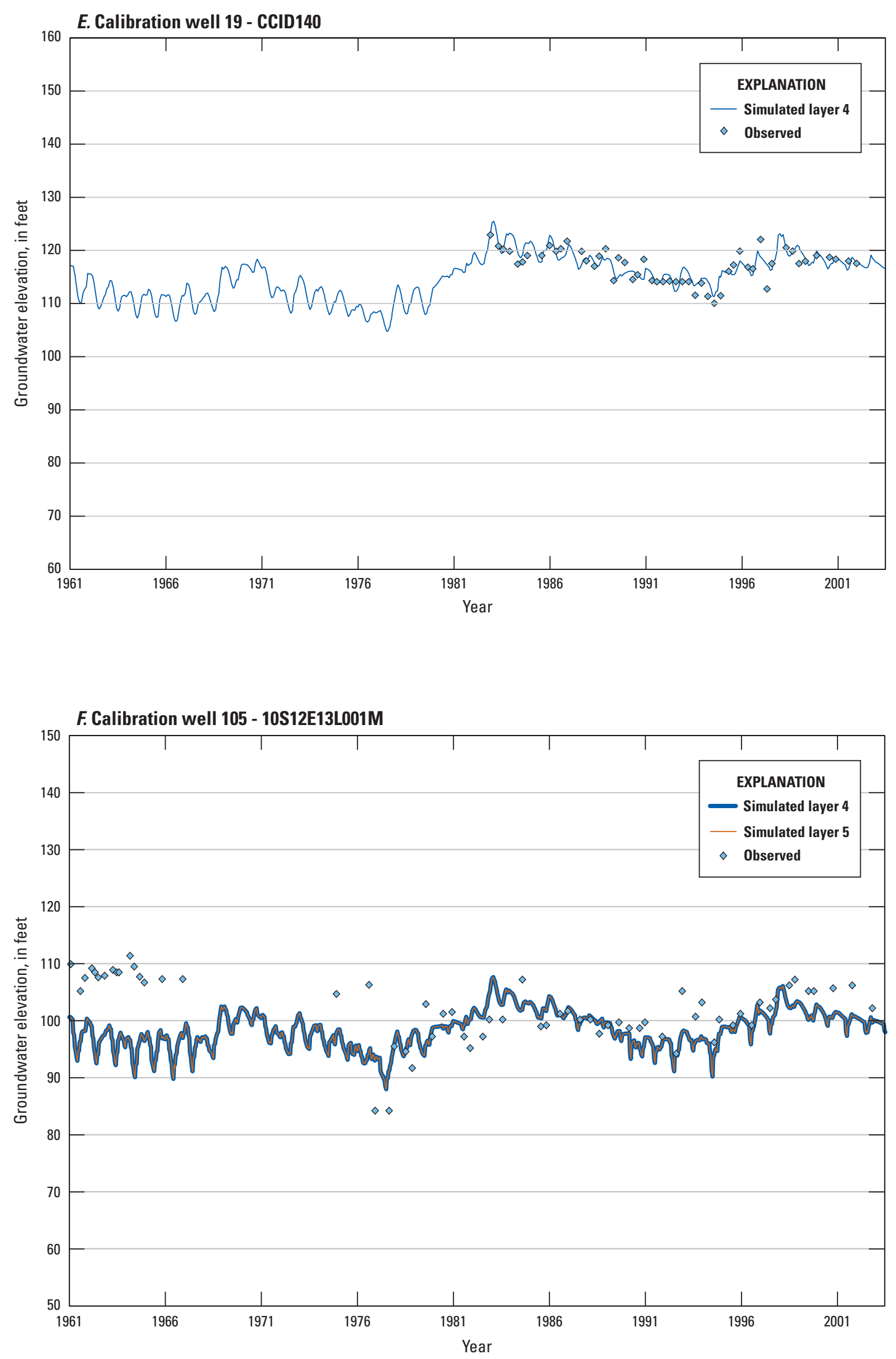

Figure 32. - Continued. 
G. Calibration well 130 - 07S10E07L001M
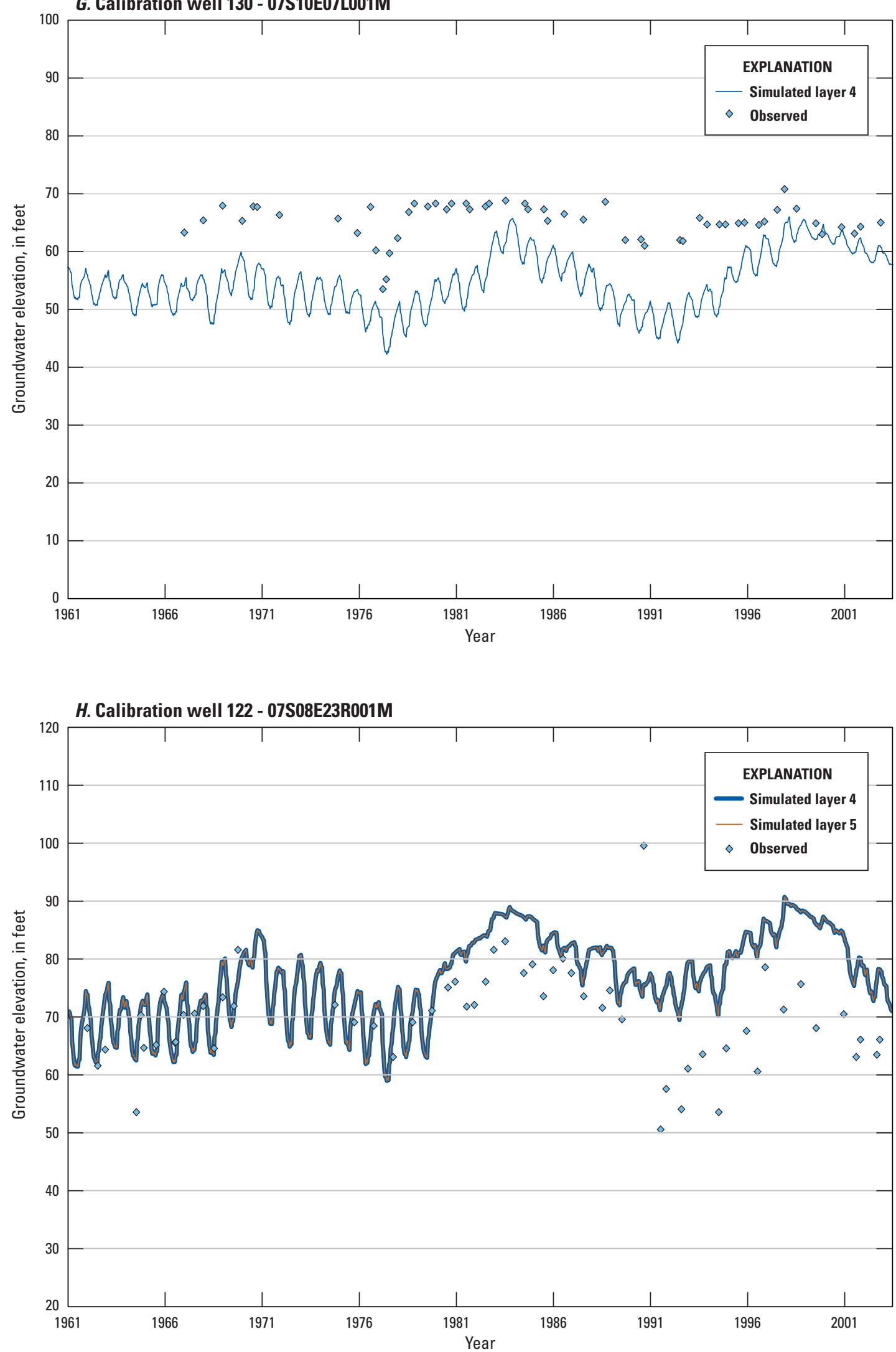

Figure 32. - Continued. 


\section{Model Fit to Streamflow Observations}

A histogram of residuals between the simulated and observed streamflow for all 4,695 observations at the 19 streamgages is shown in figure $33 \mathrm{~A}$. The residuals range from $-8,464$ to $6,818 \mathrm{ft}^{3} / \mathrm{s}$ and have a mean of $-111 \mathrm{ft}^{3} / \mathrm{s}$, an absolute mean of $234 \mathrm{ft}^{3} / \mathrm{s}$, a standard deviation of $571 \mathrm{ft}^{3} / \mathrm{s}$, a skewness of -2.6 , and an excess kurtosis of 46 . The mean value of $-111 \mathrm{ft}^{3} / \mathrm{s}$ indicates the simulated streamflows are biased slightly low. The higher value of excess kurtosis indicates more of the variance is associated with a small number of large-value residuals rather than with a larger number of small-value residuals. Approximately 77 percent of the values simulated by the SJRRPGW are within $250 \mathrm{ft}^{3} / \mathrm{s}$ of the observed values, and about 89 percent are within $500 \mathrm{ft}^{3} / \mathrm{s}$ (observed flows range from 0 to $24,200 \mathrm{ft}^{3} / \mathrm{s}$ ). Plots comparing the simulated and observed streamflow at all 19 calibration streamgages are shown in appendix $\mathrm{C}$.

The relation between observed and simulated streamflows provides a means to quantify the model fit (fig. 33B). Many of the points plot below the 1-to-1 correlation line, indicating the SJRRPGW generally simulates streamflows too low or is biased low. The greater deviation from the 1-to-1 correlation line for low streamflows indicates the model more accurately simulates high streamflows than low. The relation between residual and observed streamflow also quantifies the model fit (fig. 33C). This figure, like the previous ones, indicates the model generally simulates high streamflows too low.

The relation between the simulated and observed streamflow at the streamgage at San Joaquin River near Newman, Calif., is shown in figure 34. The model matches the temporal trends in streamflow well; however, the simulated streamflow is on average approximately $500 \mathrm{ft}^{3} / \mathrm{s}$ less than the observed streamflow. Because this streamgage is near the downstream (northwest) side of the model, it represents the total cumulative underestimation of streamflow in the SJRRPGW.

There are several reasons why the SJRRPGW underestimates streamflow by an average of $111 \mathrm{ft}^{3} / \mathrm{s}$ and cumulatively by approximately $500 \mathrm{ft}^{3} / \mathrm{s}$. Although stream inflow to the model is specified at the locations where major streams enter the model boundary, local runoff to minor streams and drains outside the model boundary that contribute to streams within the model domain is not accounted for in the model. The routing of runoff is simulated by the FMP2 for lands within the study area; however, for lands outside of the study area, these flows are not accounted for. This discrepancy is especially evident for the streamgages on Mud Slough and Salt Slough, where the simulated values are lower than the observed flows by a factor of about 10 .

In addition, there are times where surface-water deliveries to a subregion exceed the irrigation demand in that subregion as calculated by the FMP2. An option to return this surplus water to the stream system currently is not available in FMP2, so this excess water is not accounted for in the SJRRPGW streamflow network. This excess surface water not being returned to the stream network averages approximately $350 \mathrm{ft}^{3} / \mathrm{s}$.

\section{Correlation Coefficient}

The correlation coefficient $(\mathrm{R})$ is a measure of model fit that explains how well the trends in the simulated values match the trends of the observed values (Doherty, 2005). $\mathrm{R}$ is defined as:

$$
R=\frac{\sum_{m}\left(w_{m} \times h_{m}^{o b s}-\bar{h}^{o b s}\right)\left(w_{m} \times \bar{h}_{m}^{s i m}\right)}{\sqrt{\sum_{m}\left(w_{m} \times h_{m}^{o b s}-\bar{h}^{o b s}\right)^{2} \times \sum_{m}\left(w_{m} \times h_{m}^{s i m}-\bar{h}^{s i m}\right)^{2}}}
$$

where

$$
\begin{aligned}
& R \quad \text { is the correlation coefficient, } \\
& h_{m}^{o b s} \quad \text { is the value of observation } m \text {, } \\
& \bar{h}^{\text {obs }} \quad \text { is the mean of the weighted observed values, } \\
& h_{m}^{s i m} \quad \text { is the imulated value corresponding to } \\
& \text { observation } \mathrm{m} \text {, } \\
& \bar{h}^{\text {sim }} \quad \text { is the mean of the weighted simulated values, } \\
& \text { and } \\
& W_{\mathrm{m}} \quad \text { is the weight of the } m^{\text {th }} \text { observation. }
\end{aligned}
$$

Generally, a value of $\mathrm{R}$ greater than 0.9 indicates the fit between the simulated and observed trends is acceptable (Hill and Tiedeman, 2007). The weighted $\mathrm{R}$ for groundwater elevations is 0.98 , indicating an acceptable fit to observed trends. The weighted $\mathrm{R}$ for streamflow is 0.16 , which is artificially low because of the method used to weight the streamflow observations; the unweighted $\mathrm{R}$ for streamflow is 0.96 , indicating an acceptable fit to observed trends.

\section{Sensitivity Analysis and Parameter Uncertainty}

The final calibrated parameters represent the set of parameters that minimizes the sum of the squared residuals between each observation and its corresponding simulated value while obeying the prior information constraints placed on the parameters. However, it is possible with a complex hydrologic model to vary the values in the parameter set, sometimes by large amounts, and generate many alternate models with only slightly higher error. In a sense, the final calibrated parameter set can be viewed as a single set of parameters from an entire range of parameter sets that also would calibrate the model. Sensitivity tests and uncertainty analysis are, therefore, important steps in judging the performance of a complex hydrologic model (Hill and Tiedeman, 2007).

A sensitivity analysis is performed on the model parameters to test the robustness of the parameter values estimated during the calibration process. The sensitivity of each parameter is a measure of how much the simulated values (each corresponding to an observation) change with respect to a change in the parameter value. The parameter sensitivities give a sense of the tolerance within which model parameters can vary without substantially changing the model calibration. More sensitive parameters are more robust because they can only change a small amount before the model is out of calibration. Less sensitive parameters are less robust because they can change a large amount and still result in a calibrated model. 


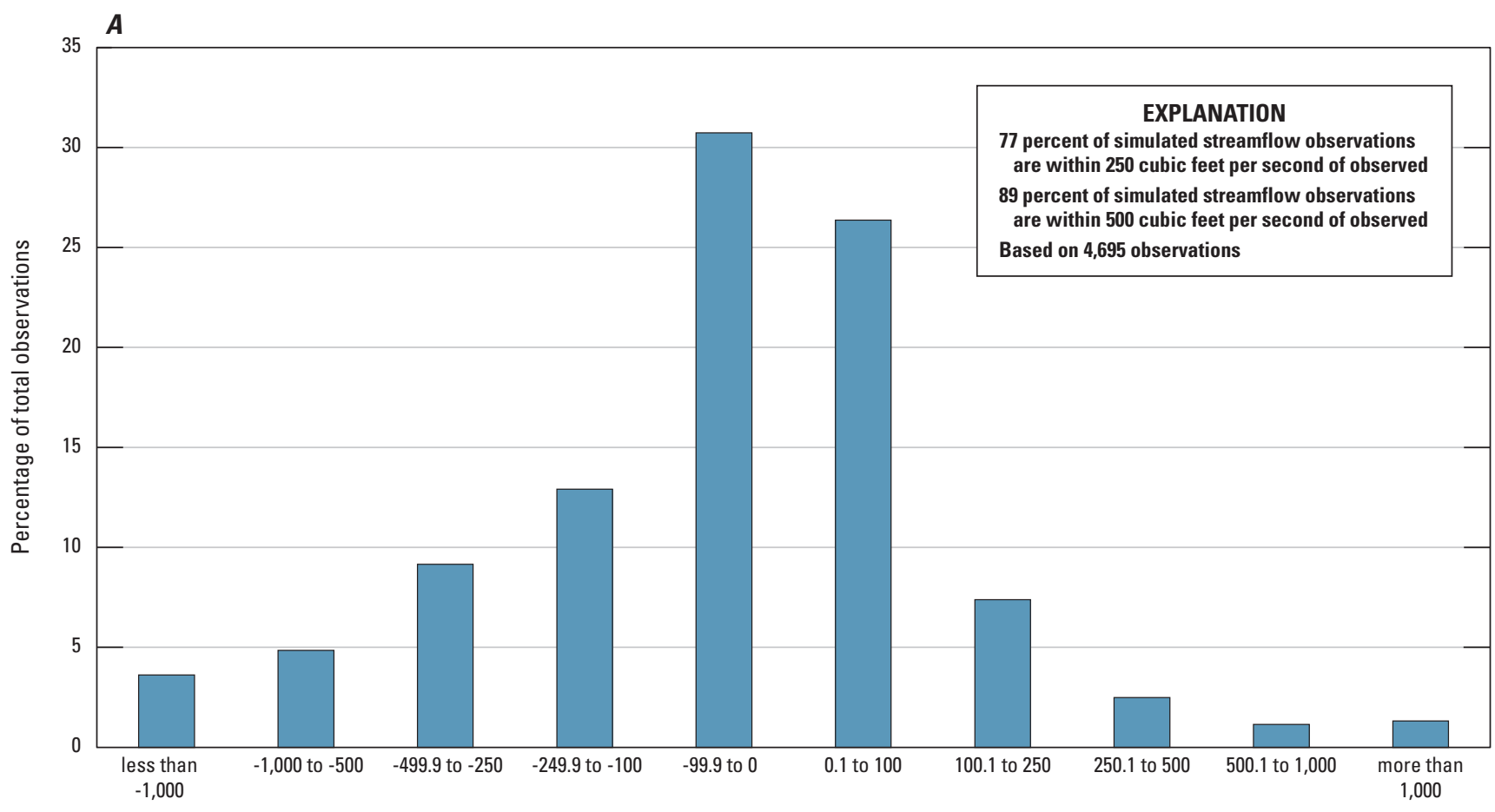

Range in residual streamflows, in cubic feet per second (Simulated minus Observed)

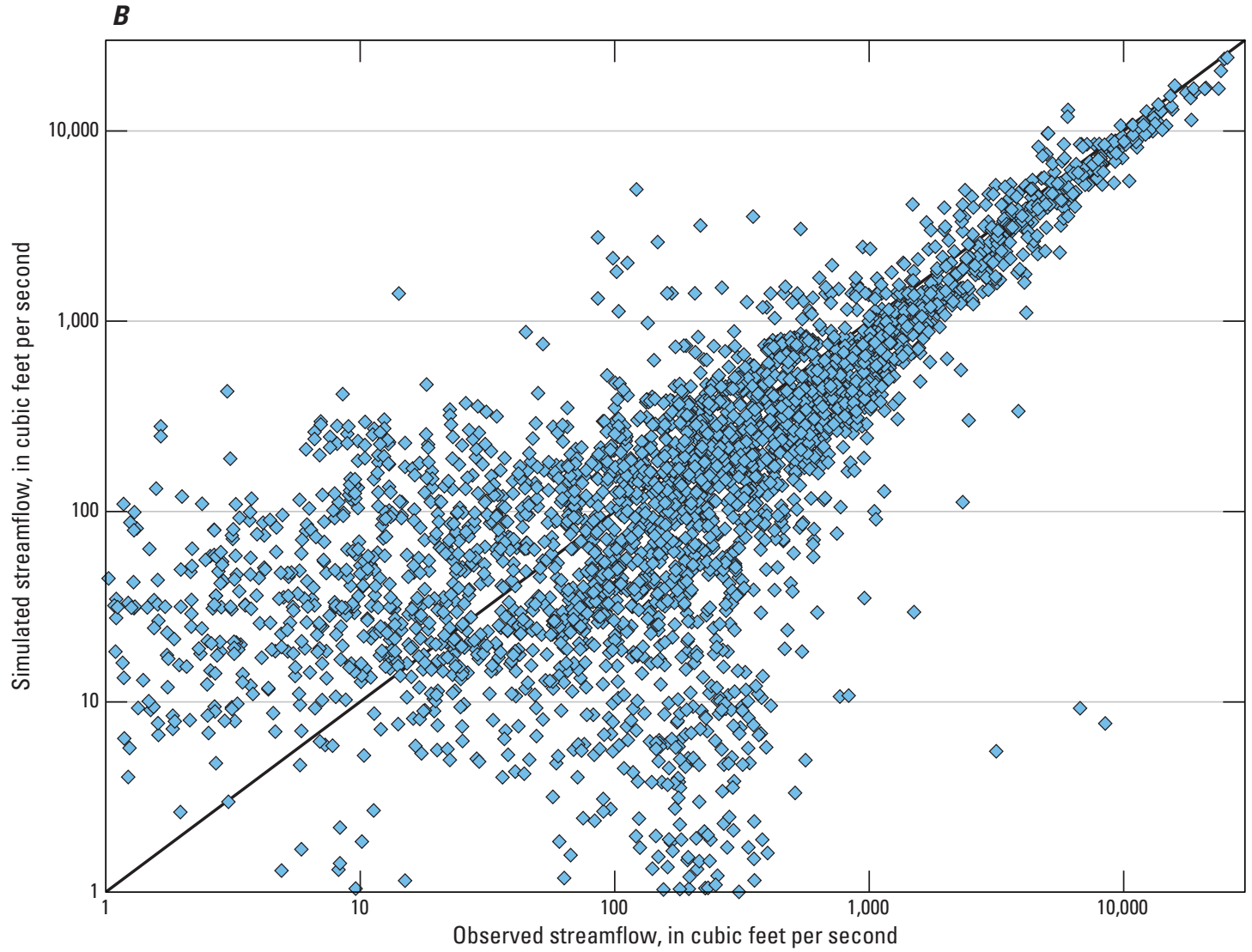

Figure 33. Relation between simulated and observed streamflows: $A$, histogram of residuals between simulated and observed streamflows; $B$, simulated and observed streamflows; $C$, residual and observed streamflows. 


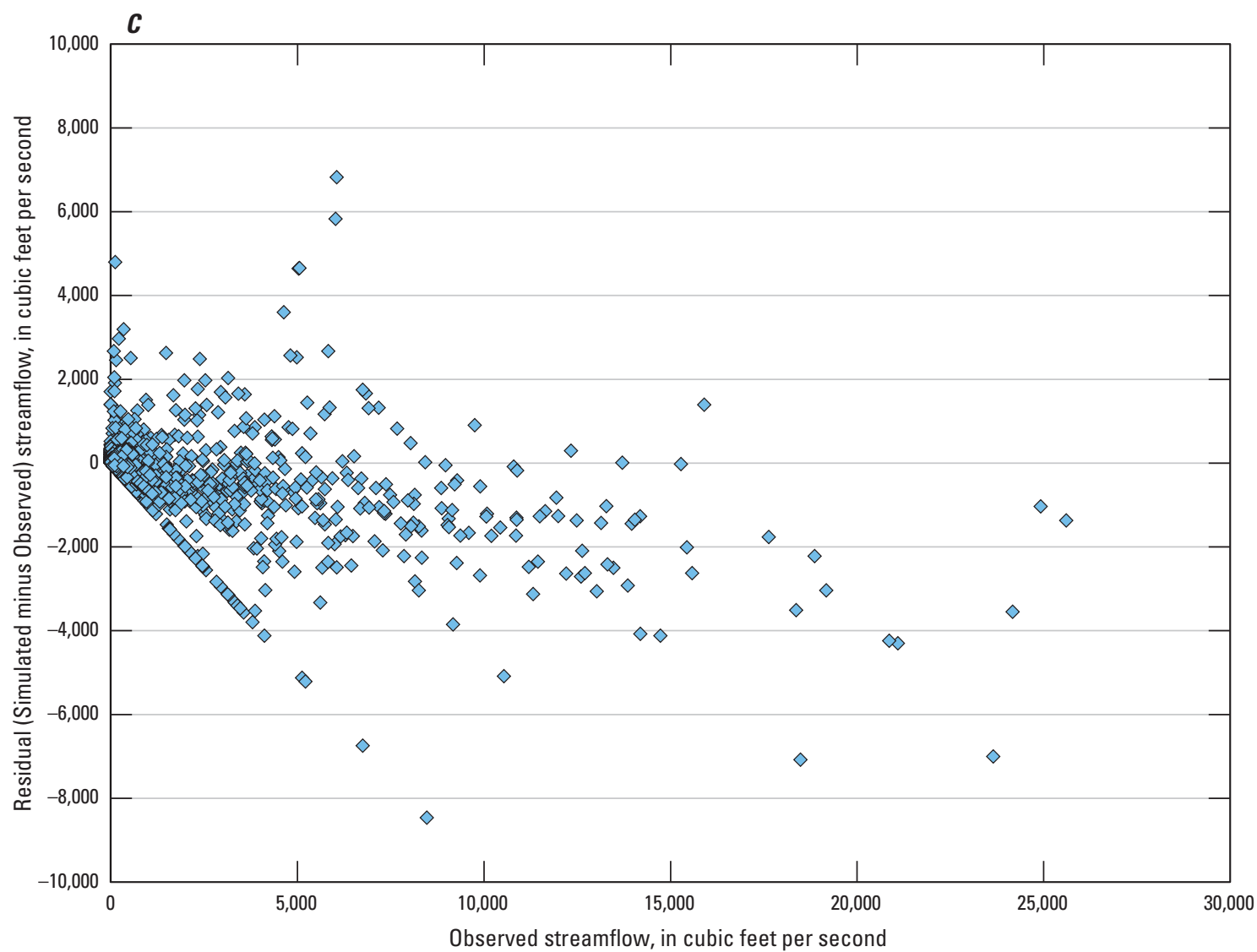

Figure 33. - Continued.

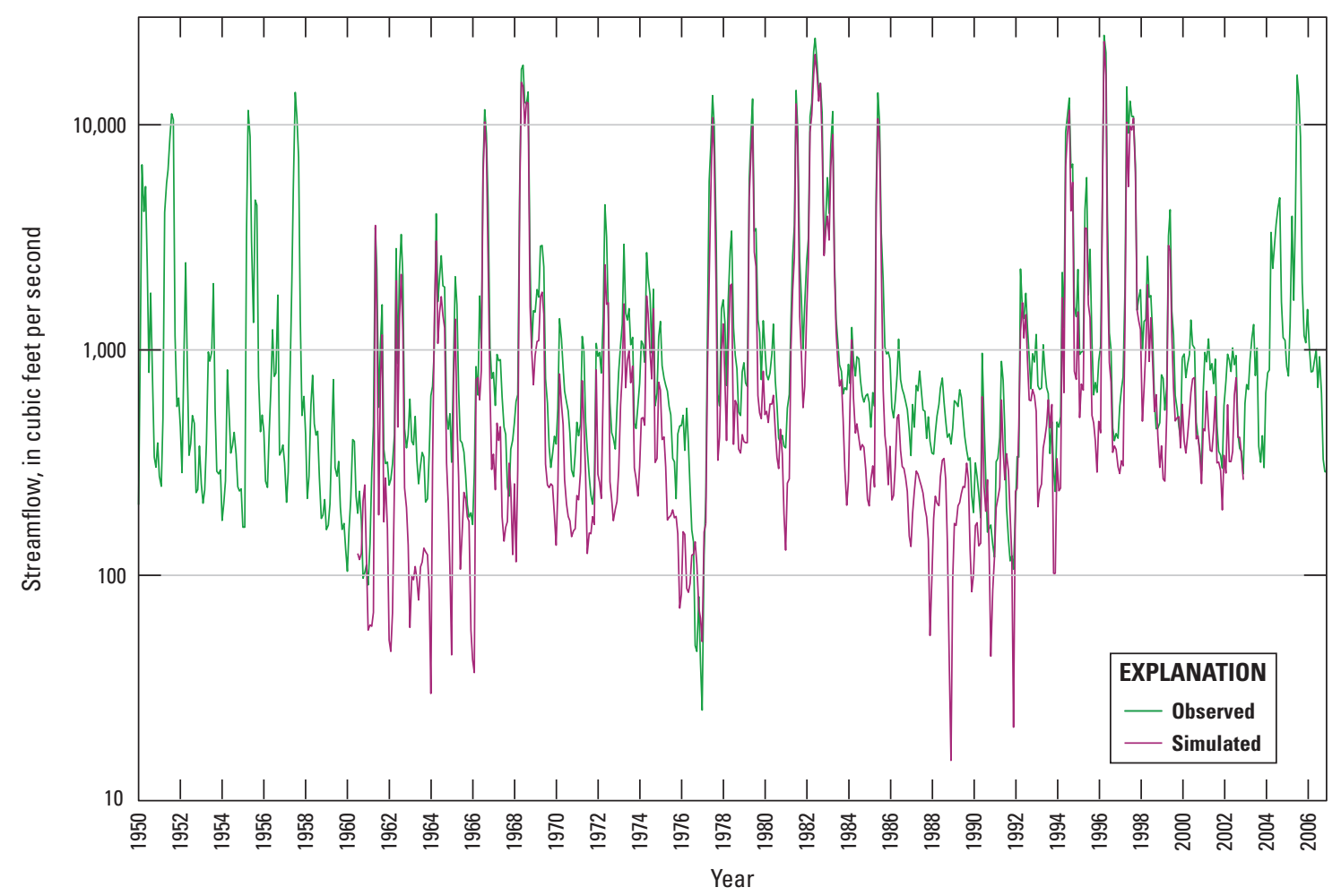

Figure 34. Simulated and observed streamflow downstream from San Joaquin River Reach 5 (San Joaquin River near Newman, California, streamgage), San Joaquin Valley, California. 
It is important to discuss some limitations to the analysis performed in this section of the report. First, the calculations presented in this section assume the SJRRPGW model results vary linearly with changes in parameter values. In reality, the model sensitivity may be greater because of the non-linear response of the model. Also, a "sensitivity analysis" only measures the variability of simulated values that correspond to an observation. One of the main purposes of the model is to estimate the groundwater and surface-water interaction associated with SJRRP flows. However, because no model observations correspond to the groundwater and surface-water interaction, it is possible some parameters (such as streambed conductivities) may be insensitive to calibration observations but very sensitive to the simulated groundwater and surfacewater interaction. For the analysis in this section, all prior information was removed from the objective function. Values for the 32 hydraulic parameters, which were log-transformed for the calibration, were not transformed for this analysis.

\section{Composite Sensitivity}

The composite sensitivity of a model parameter (Doherty, 2005) is defined as:

$$
s_{n}=\frac{\sqrt{\sum_{m}\left(J_{m n} \times w_{m}\right)^{2}}}{z}
$$

where

$$
\begin{aligned}
& S_{\mathrm{n}} \quad \text { is the composite sensitivity of the } n^{\text {th }} \\
& \text { parameter, }
\end{aligned}
$$

$J_{\mathrm{mn}} \quad$ is the change in the simulated value for the $m^{\text {th }}$ observation with respect to a change in the $n^{\text {th }}$ parameter value (the $m$-by- $n$ matrix of all these changes is known as the Jacobian matrix),

$w_{\mathrm{m}} \quad$ is the weight of the $m^{\text {th }}$ observation (same as used during calibration), and

$z \quad$ is the normalization factor (set to the number of observations by PEST).

Multiplying the composite sensitivity by the parameter value $\left(P_{\mathrm{n}}\right)$ results in the relative composite sensitivity (fig. 35A-C), which allows for better comparison of the composite sensitivities of parameters of different magnitudes. The figures show how much of the composite sensitivity of each parameter is attributed to each of the observation types (groundwater elevations, groundwater drawdowns, and streamflows), which is useful for determining parameter sensitivity to data types.

It is important to note that even with relative composite sensitivity, caution must be taken when comparing the sensitivities of different parameter types. For example, the crop-coefficient scale factor for pasture $\left(\mathrm{KC}_{-} 13\right)$ is the most sensitive parameter (fig. $35 A-C$ ). In contrast, the river-bed hydraulic conductivity for eastern tributaries (K_Trib_SE) is less than half as sensitive. This means that if $\mathrm{KC} \_13$ were doubled, it would result in roughly twice as much change in the simulated results than if $\mathrm{K}$ _Tribe_SE were doubled. However, doubling $\mathrm{KC} \_13$ would lead to a parameter value that does not make physical sense, whereas doubling K_Trib_SE would still be a plausible parameter value.

Thus, comparisons of relative composite sensitivity should be limited to parameters of the same type. For example, the horizontal hydraulic conductivity of sand (HK_Sand) is over five times as sensitive as the vertical hydraulic conductivity of sand (VK_Sand), indicating the estimate of HK_Sand is more robust. This relation makes physical sense because HK_Sand is much more likely to influence groundwater flow through the aquifer than VK_Sand. A similar relation is seen between the vertical hydraulic conductivity of clay (VK_Clay) and the horizontal hydraulic conductivity of clay (HK_Clay). When comparing the sensitivity of crop coefficients, the most sensitive values generally are for crops that have the most acreage in the study area (such as pasture, cotton, vineyards, and orchards). Similarly, the most sensitive irrigation efficiencies are for those subregions with high agricultural groundwater pumping and many calibration wells (such as Westlands Water District).

\section{Confidence Limits}

Another useful measure of parameter robustness is the 95-percent confidence limit for the estimated value of each parameter (table 12). As part of the parameter estimation process, PEST calculates the covariance between all parameter pairs (Doherty, 2005) as follows:

$$
C=\frac{\Phi}{m-n} \times\left(J^{t} \times Q \times J\right)^{-1}
$$

where

C is the covariance matrix for each parameter (n-by-n Matrix),

$\Phi \quad$ is the objective function,

$m$ is the total number of observations,

$n$ is the total number of parameters,

$J \quad$ is the Jacobian matrix ( $m$-by- $n$ matrix of the change in the simulated value for the $m^{\text {th }}$ observation with respect to a change in the $n^{\text {th }}$ parameter value), and

$Q \quad$ is the $m$-by- $m$ diagonal matrix whose diagonal elements are $w_{\mathrm{m}}$ (weight of the $m^{\text {th }}$ observation).

The variance of each parameter value $\left(P_{\mathrm{n}}\right)$ is the diagonal element of the covariance matrix for that parameter. The standard error of each parameter is the square root of the variance. The 95-percent confidence interval in each direction around the estimated parameter value is 1.96 times the standard error. 

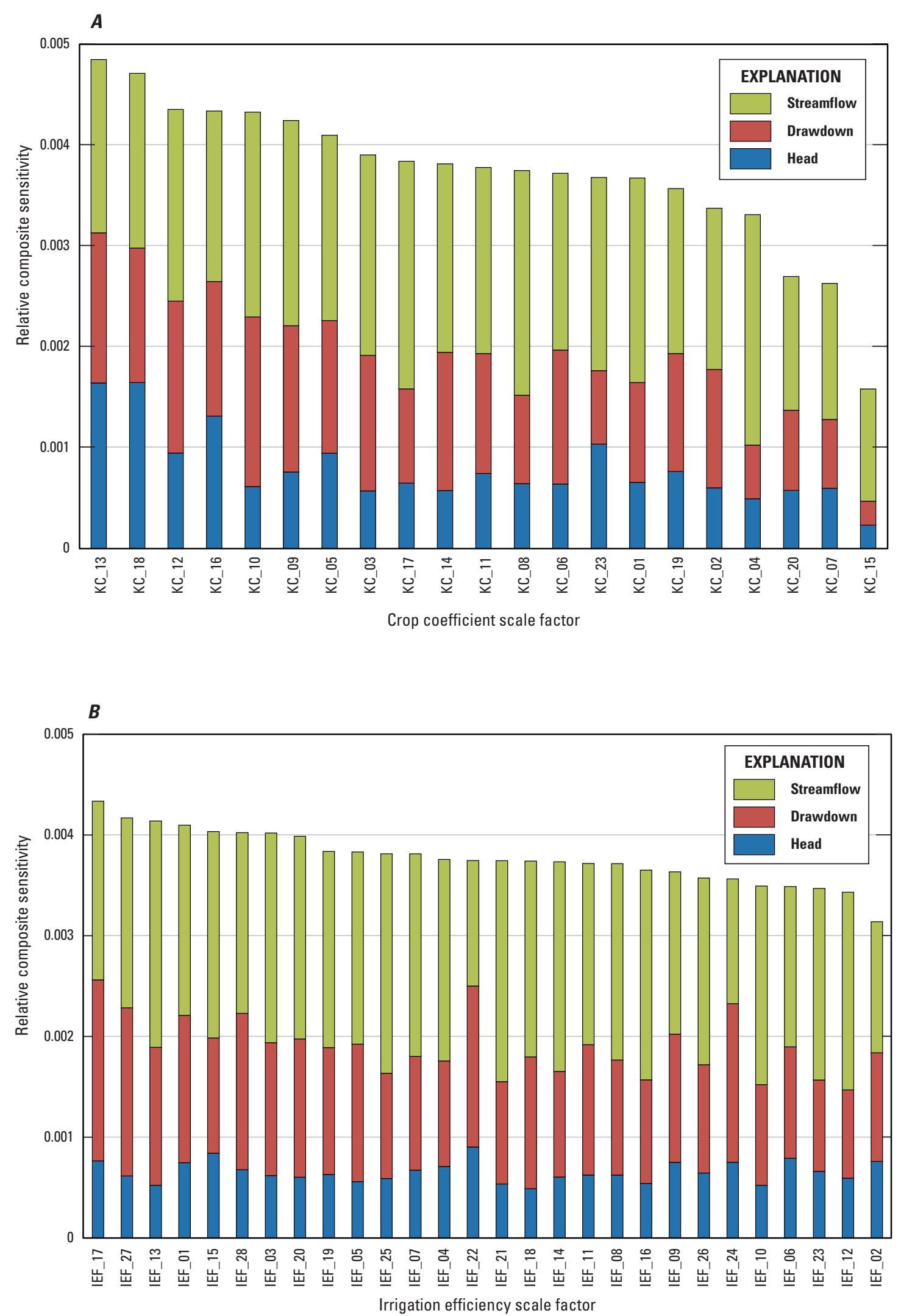

Figure 35. Relative composite sensitivities of San Joaquin River Restoration Program groundwater flow model (SJRRPGW) model parameters, San Joaquin Valley, California: $A$, sensitivity to crop coefficients for each crop type; $B$, sensitivity to irrigation efficiencies for each subregion; $C$, sensitivity to hydraulic parameters. [Hydraulic parameters are defined in table 11.] 


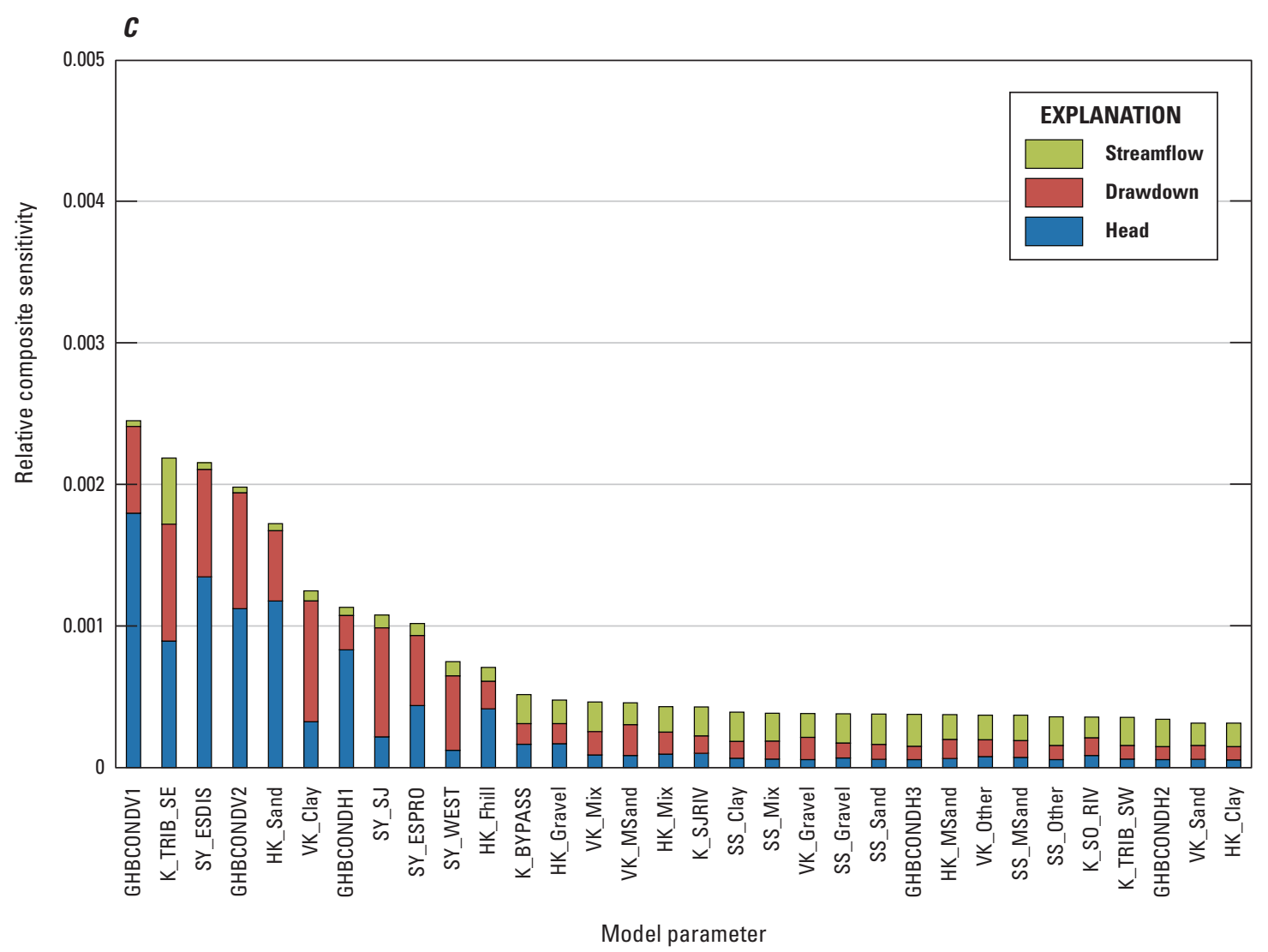

Figure 35. -Continued.

One advantage of using confidence limits is that they provide a range of sensitivity in units of actual parameter values; the traditionally used composite sensitivity method provides only a relative indicator of sensitivity. For determining the robustness of the parameter values, the confidence limits take into account the correlation between parameters. Generally, sensitive parameters are more robust (changing the parameter values by a small amount causes a large change in the simulation results), and insensitive parameters are less robust. However, in some cases, two sensitive parameters may be correlated such that a change in one parameter "cancels out" a change in the other. In these cases, the simulation results are insensitive to both parameters if they are varied together. The values of these parameters are more uncertain than is suggested by their individual sensitivities.

As an example, the lower general-head boundary conductance in the Fresno area (GHBCONDV2) is almost twice as sensitive as the lateral general-head boundary conductance for the western model boundary (GHBCONDH1) (fig. 35C). Looking only at the sensitivities suggests the parameter estimate for GHBCONDV2 is more robust than that for GHBCONDH1. However, GHBCONDV2 is moderately correlated to other parameters. Because of this correlation, considering the standard error (table 12), GHBCONDV2 has a percent standard error similar to that of GHBCONDH1, revealing the parameter estimate for GHBCONDV2 is no more robust than that for GHBCONDH1.

\section{Model Results}

Model results presented in this section include simulated hydrologic budgets, groundwater-elevation maps, and maps showing the interaction of surface water and groundwater.

\section{Simulated Hydrologic Budgets}

Budgets presented include the overall volumetric groundwater budget, the detailed farm budget from the FMP2, and the streamflow budget from the SFR2. The key components for each of these water budgets are shown in table 14 . Some budget components are reported in more than one budget (such as groundwater pumping), and slight differences in values are possible for the same component in two budgets. These differences are primarily because of the fact that groundwater budget information was obtained from the second time step of each stress period; the rates for that time step were assumed to represent the entire stress period. This approximation was used (rather than averaging both time steps) because the model output file is extremely large when both time steps are saved and the large file size was beyond the ability of available tools to process. Slight differences are also possible because of the methods used for averaging and rounding the budget values in the tables. 


\section{Groundwater Budget}

The groundwater budget provides information about the balance of flows into and out of the aquifer system in the SJRRPGW. This section presents three different ways of summarizing the groundwater budget — annual average by subregion, annual total model-wide, and monthly average model-wide.

The annual average groundwater budget for the entire simulation period for each subregion is useful for understanding the spatial distribution of the components of recharge and discharge (table 15). For example, the study area has experienced a net decline in storage over the simulation period, and this loss of storage is mostly in subregions that rely on groundwater pumping to meet demands.

Table 14. Components of San Joaquin River Restoration Program groundwater flow model (SJRRPGW) simulated hydrologic budgets, San Joaquin Valley, California.

\begin{tabular}{l}
\hline \multicolumn{1}{c}{ Groundwater budget } \\
\hline Municipal groundwater pumping \\
Agricultural groundwater pumping \\
Net percolation to groundwater ${ }^{1}$ \\
Net stream seepage to groundwater \\
Net subsurface boundary flow \\
Net inter-subregion flow \\
Convergence discrepancy \\
Change in groundwater storage \\
\hline
\end{tabular}

Farm budget

Precipitation

Surface-water delivery

Agricultural groundwater pumping

Groundwater uptake by plants

Crop consumptive use

Runoff to streams ${ }^{2}$

Percolation to groundwater ${ }^{2}$

Unused surface water

\begin{tabular}{l}
\hline \multicolumn{1}{c}{ Streamflow budget } \\
\hline San Joaquin River inflow \\
Merced River inflow \\
Kings River inflow \\
Other streams inflow \\
Runoff to streams ${ }^{2}$ \\
Net diversions \\
Net stream seepage to groundwater \\
San Joaquin River outflow \\
\hline
\end{tabular}

${ }^{1}$ From both precipitation and irrigation.

${ }^{2} \mathrm{Net}$ percolation to groundwater is the difference between percolation to groundwater and groundwater uptake by plants.
The annual groundwater budget for the SJRRPGW from 1962 to 2003 is useful for understanding how the components of the groundwater budget change through time during the simulation period (table 16 and fig. 36). Many of the groundwater-budget components are dependent on hydrology, such as net stream seepage. Some components are dependent on land use, such as municipal pumping. Other components are more complex, depending on a variety of factors. Agricultural pumping, for example, is dependent on hydrology because dry years require more pumping due to decreased rainfall and associated surface-water deliveries, but agricultural pumping generally decreases over time due to increased irrigation efficiencies, increased surface-water availability, and changing crop types. The cumulative annual change in aquifer storage between 1962 and 2003 shows an increase in groundwater storage during wet years and a decrease in groundwater storage during dry years (fig. 36).

The monthly average groundwater budget for the SJRRPGW is useful for understanding how the components of the groundwater budget vary by month (table 17). Agricultural pumping shows a seasonal pattern; most of the pumping occurs during the growing season. Groundwater recharge by net percolation shows a bimodal distribution; most recharge occurs during January and February, when precipitation is greatest, and during July, when irrigation is greatest. On average, the aquifer loses storage during the growing season and gains storage during the rainy season.

\section{Farm Budget}

The farm budget provides information about the water demand of crops and other plants in the study area and the various water supplies that meet this demand. This section presents three different ways of summarizing the farm budget - annual average by subregion, annual total model-wide, and monthly average model-wide.

The annual average farm budget for the entire simulation period for each subregion is useful for understanding the spatial distribution of supply and demand (table 18). For example, subregions on the west side of the San Joaquin River, such as Grasslands Water District (5) and San Luis Canal Company (9), receive predominantly surface water; subregions on the east side of the San Joaquin River, such as unorganized Madera County (12), rely predominantly on groundwater. Groundwater uptake by plants occurs in subregions where the water table is shallow. The annual average farm budgets for agricultural water supply and demand for each subregion are shown in figures 37 and 38, respectively.

The annual farm budget for the SJRRPGW from 1962 to 2003 is useful for understanding how the components of the farm budget change through time during the simulation period (table 19 and fig. 39). Many of the farm-budget components are dependent on hydrology, such as surface-water delivery; the minimum surface-water delivery $(415,000 \mathrm{acre}-\mathrm{ft} / \mathrm{yr})$ was in 1977 , a critically dry year. Groundwater uptake by plants is greatest in years with above-average precipitation, runoff, and 


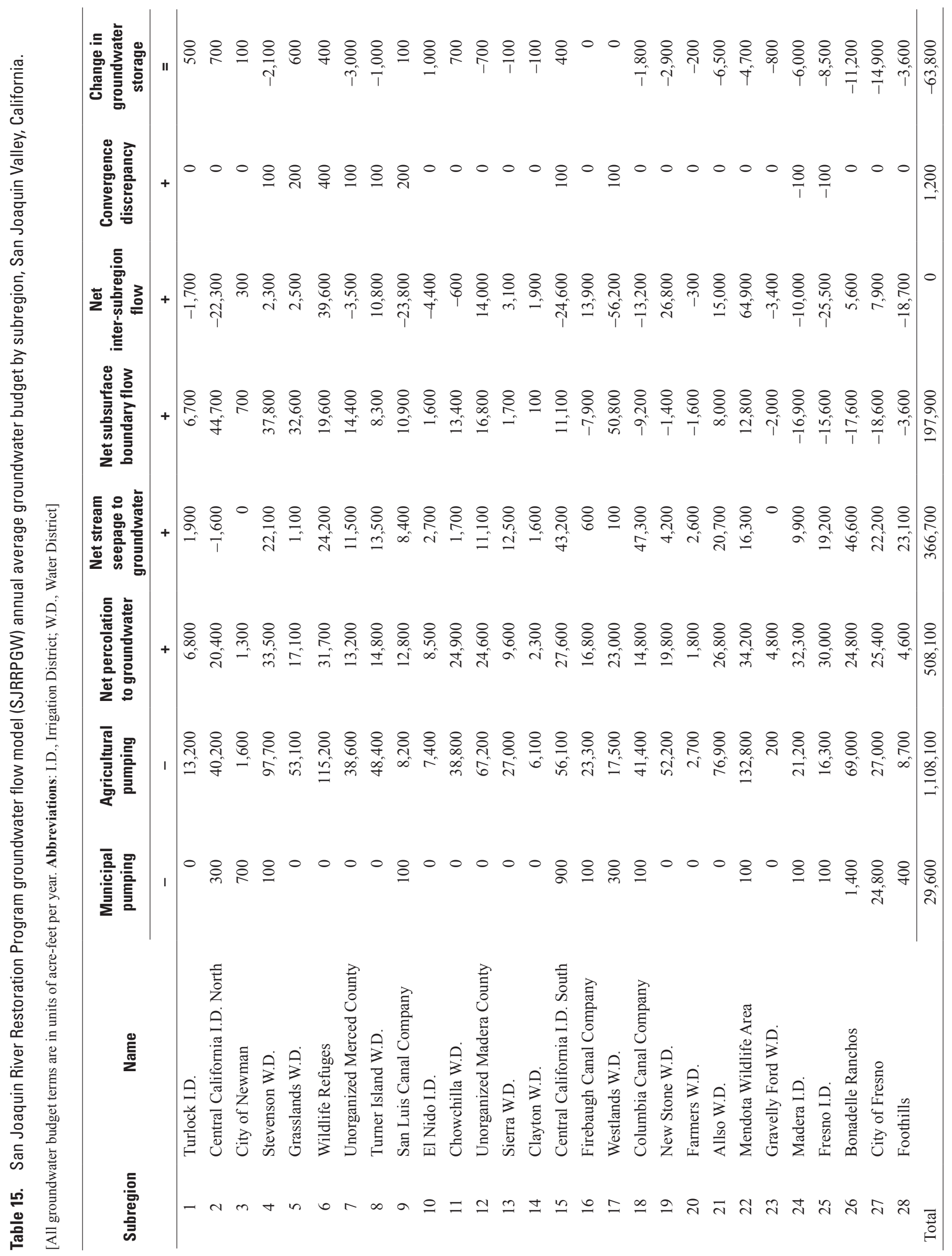




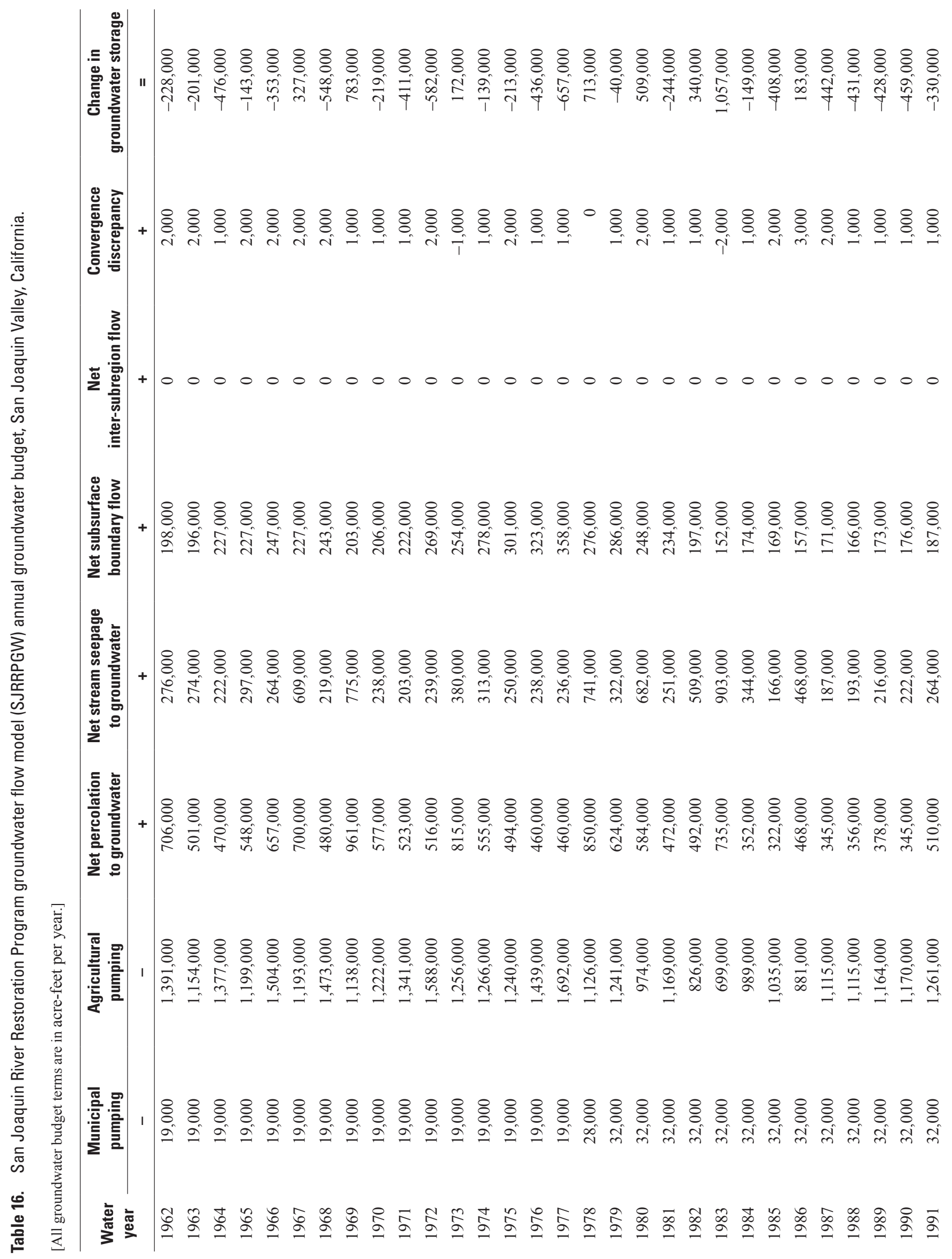




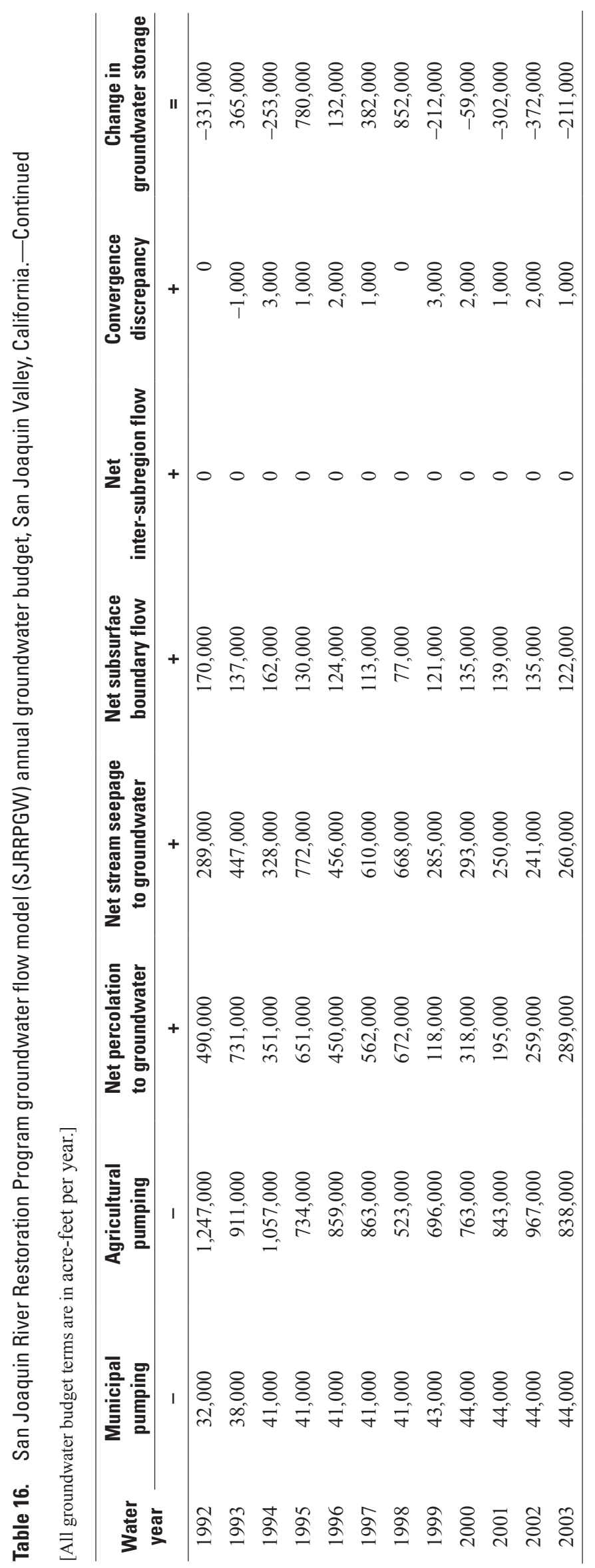



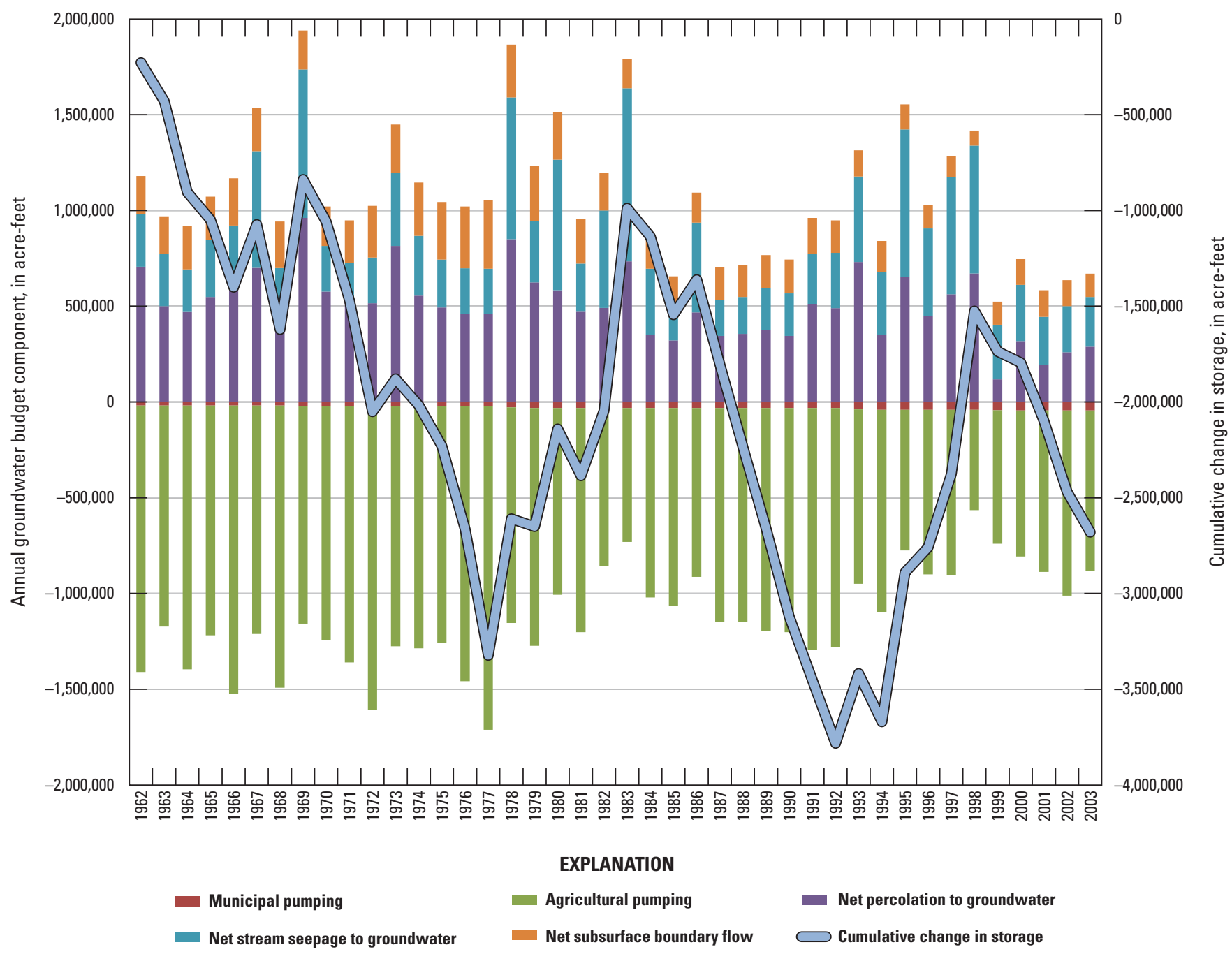

Figure 36. San Joaquin River Restoration Program groundwater flow model (SJRRPGW) annual groundwater budget and cumulative change in groundwater storage, San Joaquin Valley, California. 
Table 17. San Joaquin River Restoration Program groundwater flow model (SJRRPGW) monthly average groundwater budget, San Joaquin Valley, California.

[All groundwater budget terms are in acre-feet per year.]

\begin{tabular}{|c|c|c|c|c|c|c|c|c|}
\hline Month & $\begin{array}{l}\text { Municipal } \\
\text { pumping }\end{array}$ & $\begin{array}{l}\text { Agricultural } \\
\text { pumping }\end{array}$ & $\begin{array}{c}\text { Net } \\
\text { percolation to } \\
\text { groundwater }\end{array}$ & $\begin{array}{l}\text { Net stream } \\
\text { seepage to } \\
\text { groundwater }\end{array}$ & $\begin{array}{c}\text { Net } \\
\text { subsurface } \\
\text { boundary flow }\end{array}$ & $\begin{array}{l}\text { Net inter- } \\
\text { subregion } \\
\text { flow }\end{array}$ & $\begin{array}{l}\text { Convergence } \\
\text { discrepancy }\end{array}$ & $\begin{array}{c}\text { Change in } \\
\text { groundwater } \\
\text { storage }\end{array}$ \\
\hline & - & - & + & + & + & + & + & $=$ \\
\hline 1 & 1,400 & 9,900 & 74,500 & 31,700 & 8,300 & 0 & -100 & 103,300 \\
\hline 2 & 1,300 & 20,100 & 61,100 & 41,800 & 9,000 & 0 & -100 & 90,400 \\
\hline 3 & 1,600 & 38,200 & 34,500 & 36,000 & 11,200 & 0 & 0 & 41,800 \\
\hline 4 & 2,200 & 63,800 & 19,200 & 39,900 & 14,000 & 0 & 100 & 7,200 \\
\hline 5 & 3,000 & 114,200 & 26,500 & 36,000 & 19,000 & 0 & 200 & $-35,500$ \\
\hline 6 & 3,500 & 178,500 & 42,000 & 40,300 & 24,200 & 0 & 300 & $-75,100$ \\
\hline 7 & 4,000 & 209,500 & 53,300 & 39,600 & 27,200 & 0 & 400 & $-93,100$ \\
\hline 8 & 3,800 & 207,500 & 51,400 & 31,600 & 26,900 & 0 & 500 & $-101,000$ \\
\hline 9 & 3,200 & 167,000 & 39,900 & 17,600 & 24,100 & 0 & 300 & $-88,300$ \\
\hline 10 & 2,500 & 75,000 & 17,900 & 14,800 & 15,300 & 0 & 0 & $-29,600$ \\
\hline 11 & 1,700 & 14,400 & 37,300 & 16,300 & 9,900 & 0 & -100 & 47,200 \\
\hline 12 & 1,500 & 10,000 & 50,500 & 21,200 & 8,700 & 0 & -100 & 68,900 \\
\hline
\end{tabular}




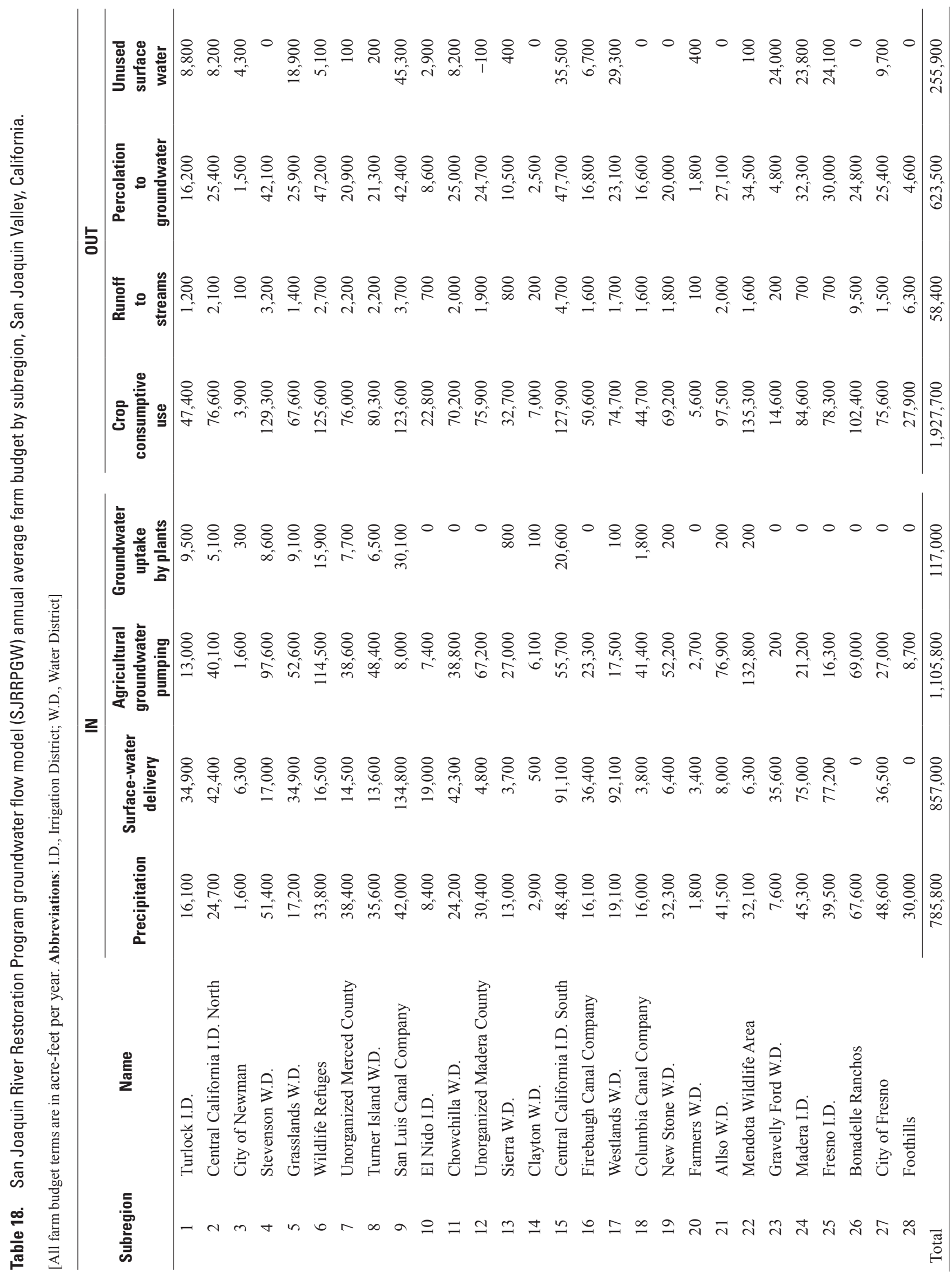




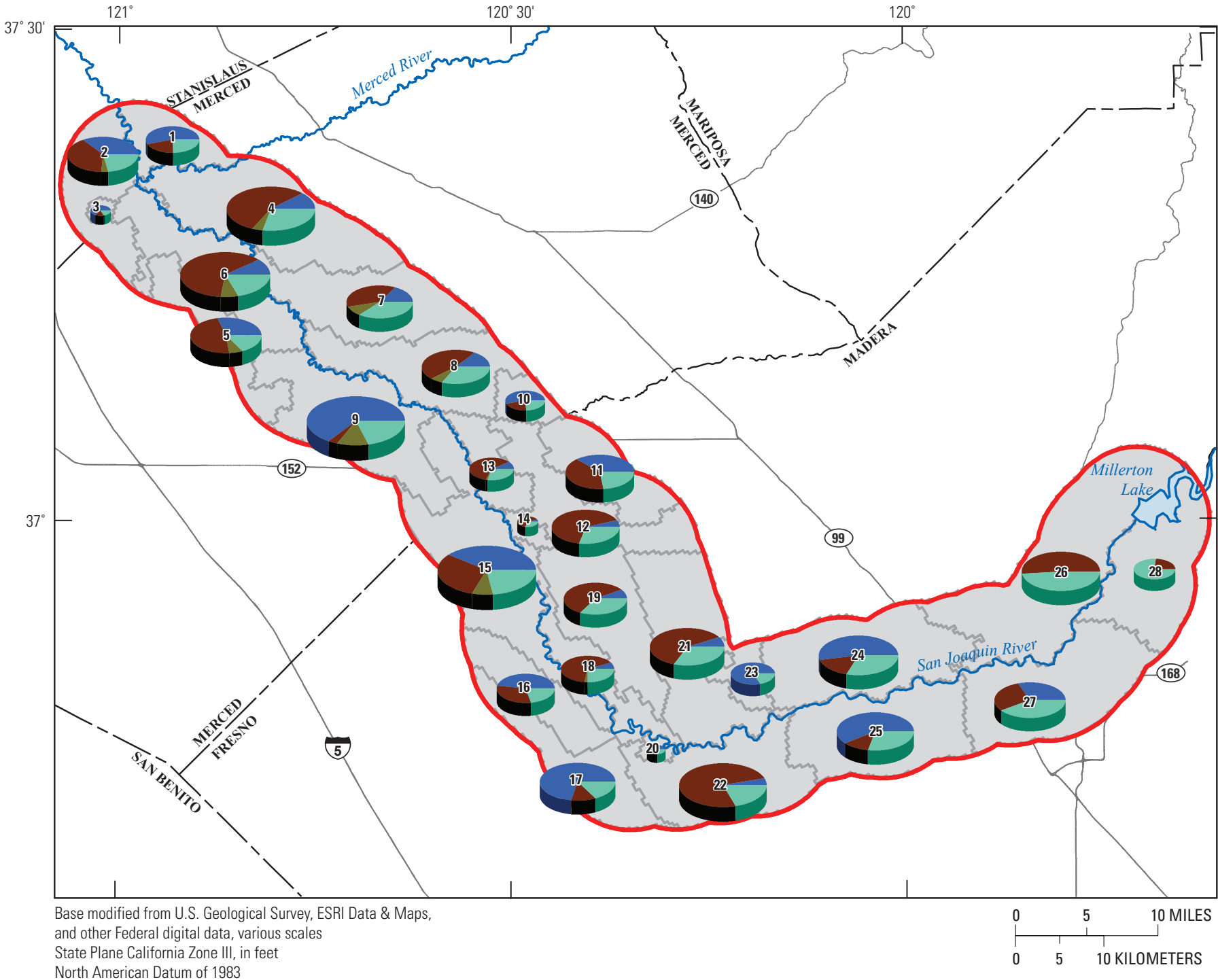

EXPLANATION

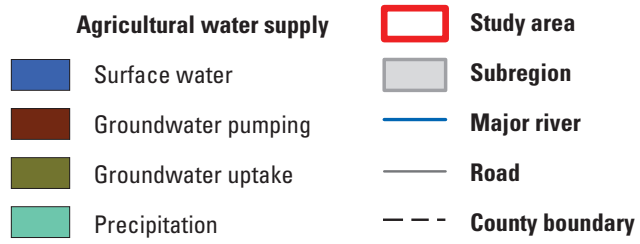

Figure 37. San Joaquin River Restoration Program groundwater flow model (SJRRPGW) agricultural water supply by subregion, San Joaquin Valley, California. 


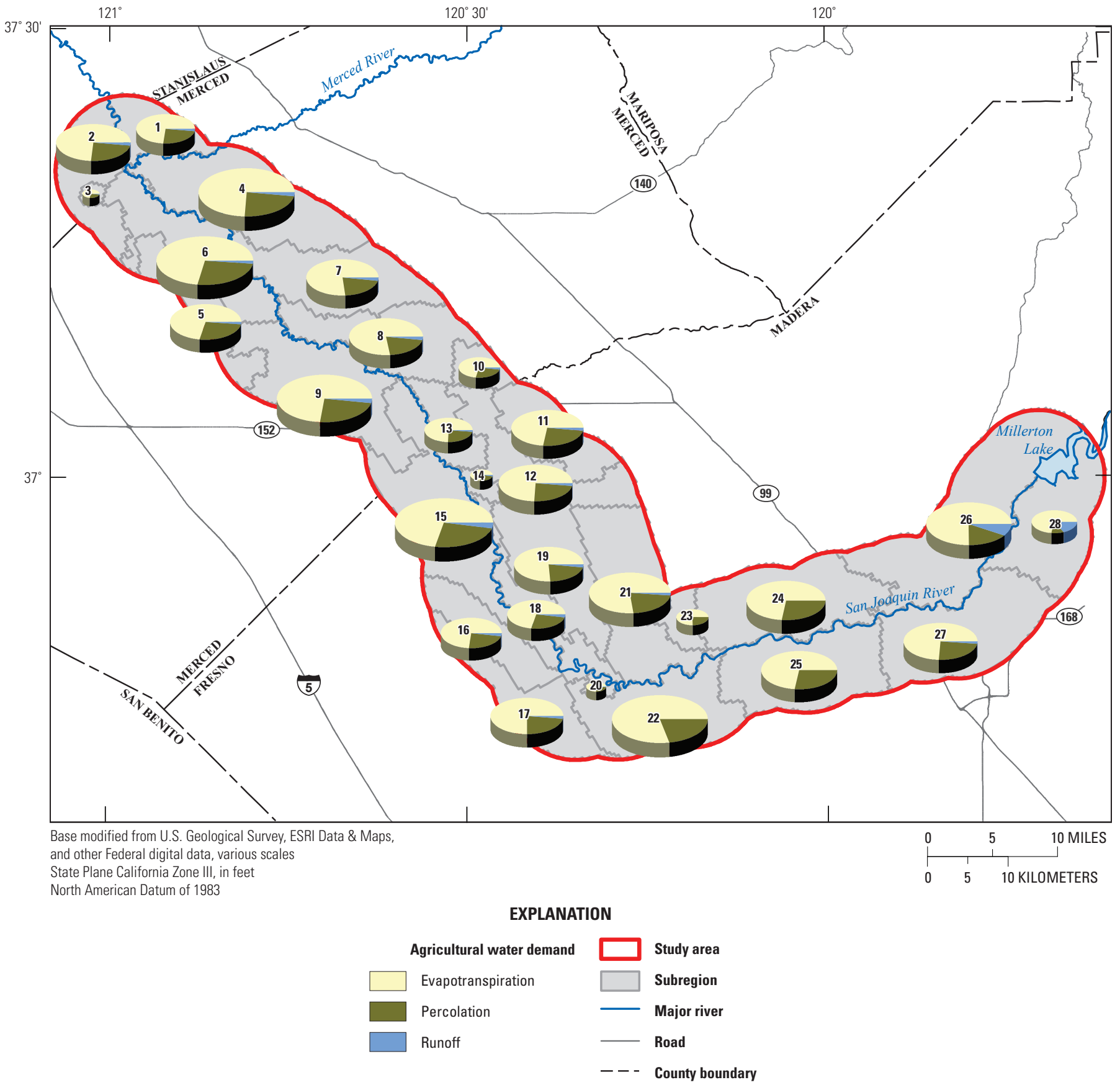

Figure 38. San Joaquin River Restoration Program groundwater flow model (SJRRPGW) agricultural water demand by subregion, San Joaquin Valley, California. 


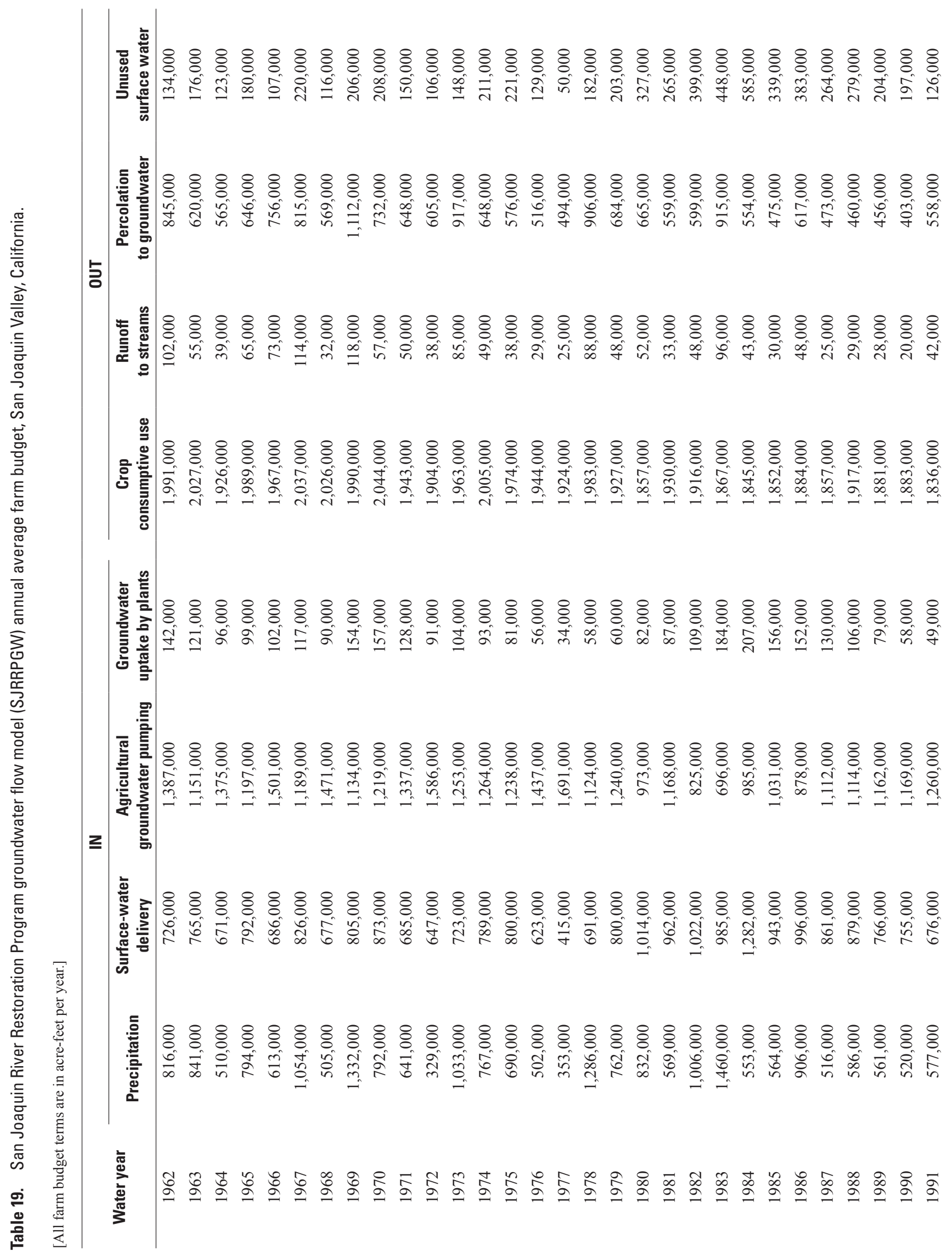




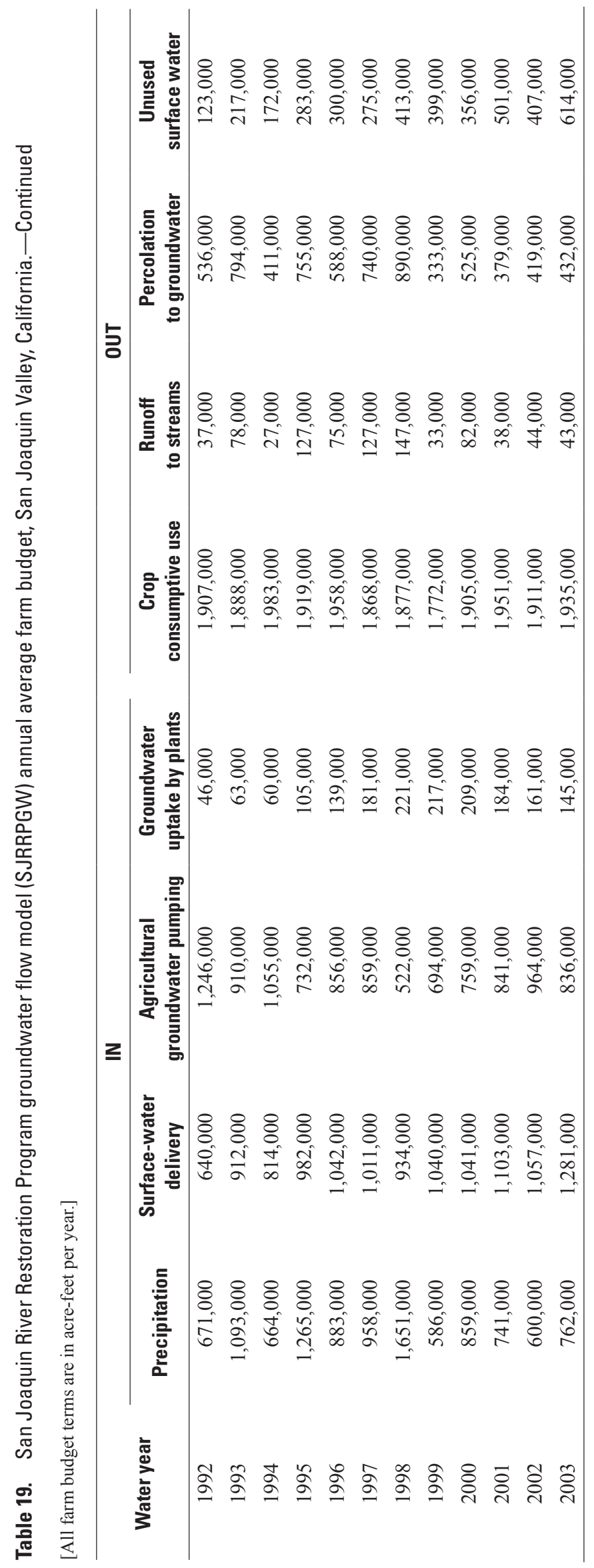




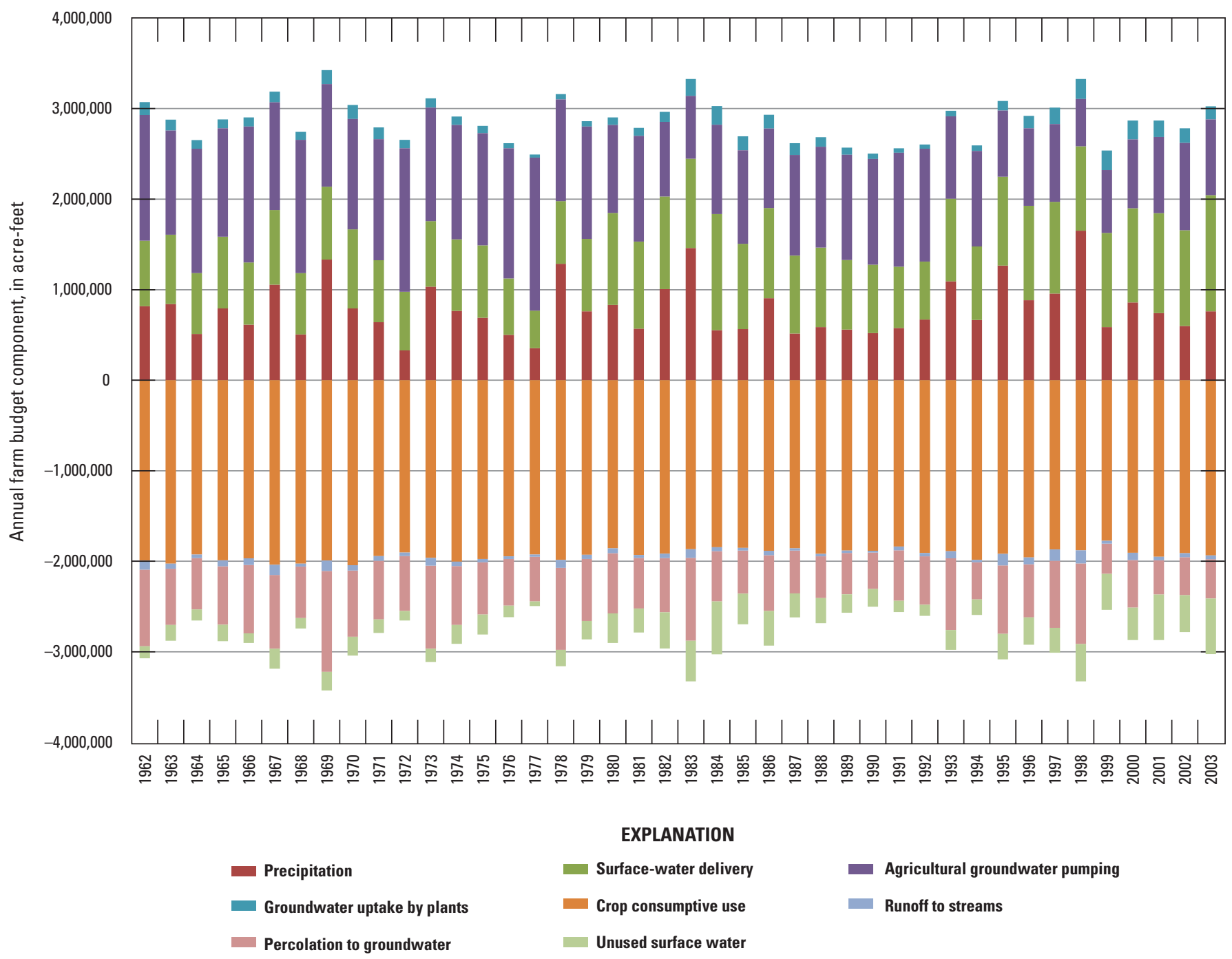

Figure 39. San Joaquin River Restoration Program groundwater flow model (SJRRPGW) annual average farm budget, San Joaquin Valley, California. 
associated water-table elevation, such as 1984 and 1998. Crop consumptive use shows a slight decline over time as land use shifts from crops with higher consumptive use to ones with lower consumptive use. Groundwater recharge by percolation of applied water below the root zone decreases through time because of increases in irrigation efficiencies and declines in consumptive use.

The monthly average farm budget for the SJRRPGW is useful for understanding how the components of the farm budget vary by month (table 20). Most crop consumptive use occurs during the growing season, whereas most precipitation occurs in the rainy season. The larger quantities of unused surface water in March, April, and May are likely pre-irrigation deliveries; this process is not simulated by the FMP2.

\section{Streamflow Budget}

The streamflow budget provides information about the inflows and outflows to the stream network in the study area. This section presents two ways of summarizing the streamflow budget as well as the annual groundwater and surface-water interaction for each of the management reaches along the San Joaquin River. Note, seepage rates are highly dependent on flow in the river, so seepage rates that will occur under restoration flows are likely to be different than historical seepage rates because of the differences in the timing and magnitude of streamflow.

The annual streamflow budget for the SJRRPGW from 1962 to 2003 is useful for understanding how the components of the streamflow budget change through time during the simulation period (table 21). The average annual net groundwater recharge attributed to stream seepage is 367,000 acre-ft/yr $\left(510 \mathrm{ft}^{3} / \mathrm{s}\right)$, which includes the seepage from the main San Joaquin River channel, the San Joaquin River flood-control bypass system, and the major San Joaquin River tributaries. The median stream seepage rate was 281,000 acre-ft/yr; the annual stream seepage ranged from 903000 acre-ft in 1983 to 166,000 acre-ft in 1985 . San Joaquin River releases from Friant Dam are small except during flood-release periods. Flow from the Kings River Basin is limited to flood releases only. Inflow from the Merced River and from other streams is more steady but is still heavily dependent on hydrology. Net diversions represent the difference between CVP water that flows into the San Joaquin River from the Delta Mendota Canal and Mendota pool and the CVP water diverted from the San Joaquin River between Mendota Pool and Sack Dam. Negative net diversion indicates the Delta Mendota inflow is greater than what is diverted off the river.

Table 20. San Joaquin River Restoration Program groundwater flow model (SJRRPGW) monthly average farm budget, San Joaquin Valley, California.

[All farm budget terms are in acre-feet per month.]

\begin{tabular}{|c|c|c|c|c|c|c|c|c|}
\hline \multirow[b]{2}{*}{ Month } & \multicolumn{4}{|c|}{ IN } & \multicolumn{4}{|c|}{ OUT } \\
\hline & Precipitation & $\begin{array}{c}\text { Surface-water } \\
\text { delivery }\end{array}$ & $\begin{array}{c}\text { Agricultural } \\
\text { groundwater } \\
\text { pumping }\end{array}$ & $\begin{array}{c}\text { Groundwater } \\
\text { uptake by } \\
\text { plants }\end{array}$ & $\begin{array}{c}\text { Crop } \\
\text { consumptive } \\
\text { use }\end{array}$ & $\begin{array}{c}\text { Runoff } \\
\text { to } \\
\text { streams }\end{array}$ & $\begin{array}{c}\text { Percolation } \\
\text { to } \\
\text { groundwater }\end{array}$ & $\begin{array}{c}\text { Unused } \\
\text { surface } \\
\text { water }\end{array}$ \\
\hline 1 & 150,700 & 13,400 & 9,900 & 3,400 & 76,400 & 12,600 & 77,900 & 10,400 \\
\hline 2 & 145,300 & 26,900 & 20,100 & 4,700 & 102,800 & 9,600 & 65,700 & 18,900 \\
\hline 3 & 126,700 & 56,900 & 38,200 & 8,600 & 145,000 & 4,400 & 43,800 & 37,200 \\
\hline 5 & 24,400 & 107,800 & 113,900 & 14,000 & 183,800 & 1,500 & 40,200 & 34,500 \\
\hline 6 & 6,400 & 139,400 & 178,000 & 18,200 & 252,700 & 2,800 & 59,700 & 27,000 \\
\hline 7 & 1,300 & 159,200 & 208,900 & 18,900 & 289,000 & 3,600 & 71,500 & 24,100 \\
\hline 8 & 2,100 & 127,700 & 207,000 & 16,900 & 267,800 & 3,700 & 67,700 & 14,400 \\
\hline 12 & 111,400 & 10,000 & 10,000 & 2,900 & 64,000 & 9,400 & 53,400 & 7,500 \\
\hline
\end{tabular}


Table 21. San Joaquin River Restoration Program groundwater flow model (SJRRPGW) annual average streamflow budget, San Joaquin Valley, California.

[All streamflow budget terms are in acre-feet per year.]

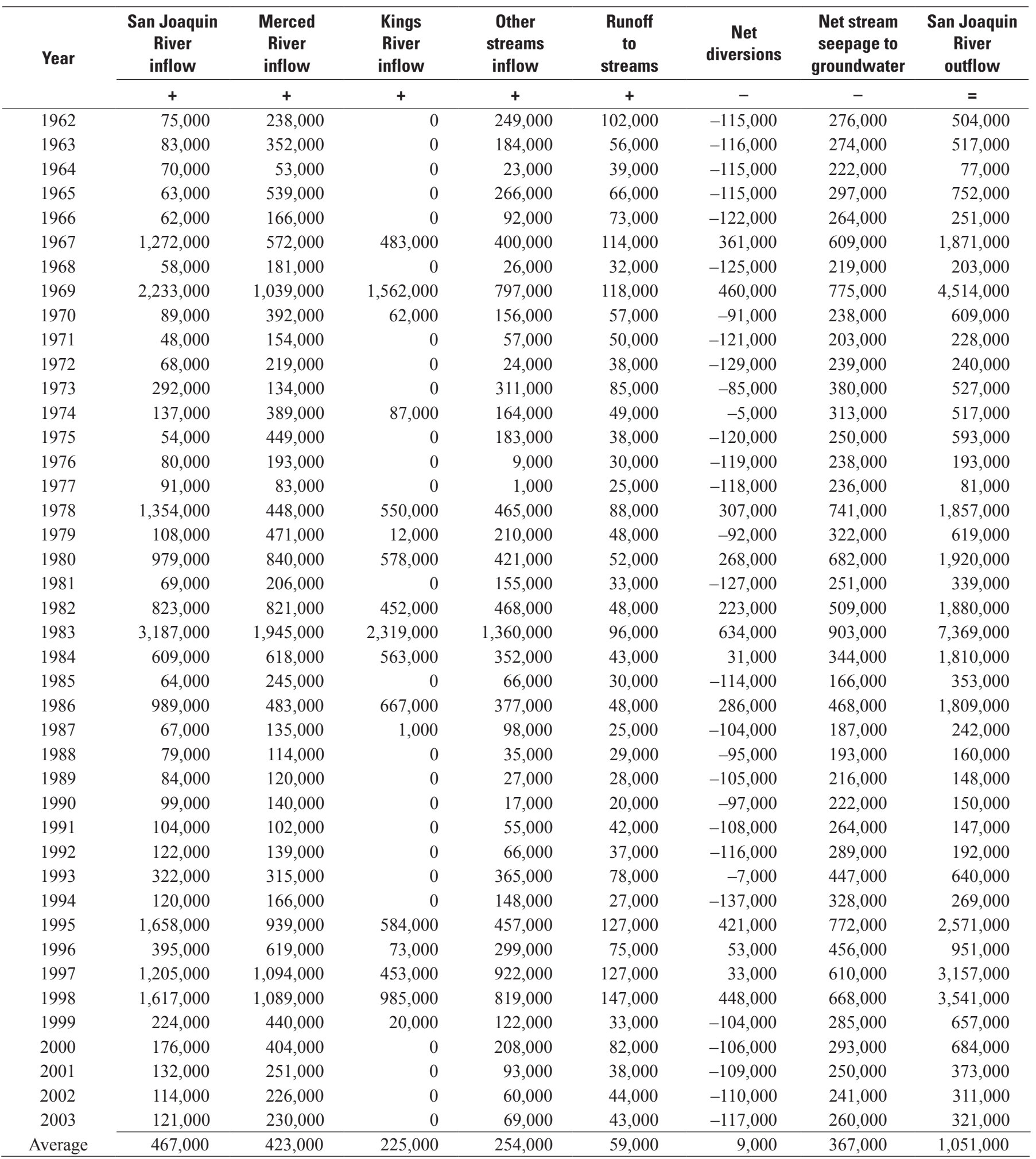


The monthly average streamflow budget for the SJRRPGW is useful for understanding how the components of the streamflow budget vary by month (table 22). All stream inflows to the model are greatest during April and May when runoff from the Sierra Nevada is greatest. Runoff to streams is greatest during January, when rainfall is greatest, but it also has a secondary peak during August because of runoff of irrigation water.

The highest seepage rates are in Reaches 1 and 3 (fig. $40 \mathrm{~A}$ and fig. 40C) because these reaches always have flow in them. Reach 1 has flow from Friant Dam releases, and Reach 3 has flow from CVP water released from Mendota Pool. Reach 5 has negative seepage rates (where there is a net groundwater discharge to the stream) between 1999 and 2002 (fig. 40E).

\section{Maps of Water-Table Elevation}

Maps of depth to the water table were developed for fall 1981, 1983, 1988, 1991, and 2006 (fig. 8A-E). Maps of the SJRRPGW-simulated water-table elevation and depth to the water table for fall of these same years, except for 2006, which is beyond the simulation period, are presented in figures $41 A-H$.

The 1981 simulated water-table elevation map (fig. 41A) represents a Normal-Dry year. The elevation of the water table generally decreases down the axis of the San Joaquin River. The gradient of the water table is away from Reaches 1 and 2, indicating a losing stream. The simulated water table is flatter in the lower reaches. A notable groundwater depression is to the east of Reach 4A and is primarily caused by agricultural pumping. A depth to groundwater of between 5-15 ft is simulated west of Reaches 3, 4A, and 4B1 (fig. 41B). The model results generally match the map of observed depth to water (fig. $8 \mathrm{~A}$ ) for this area. The model simulates greater depth to water than observed west of Reaches $2 \mathrm{~B}$ and 4B2; however, these areas are relatively poorly constrained by observation wells.

The 1983 simulated water-table elevation map (fig. 41C) represents a Wet year preceded by a Wet year. The simulated water table rose by around 5-10 ft in most areas relative to 1981 . The water table also partially recovered in the groundwater depression east of Reach 4A. A water-table rise associated with seepage from the Chowchilla and Eastside bypasses and from other streams in the study area also is evident. The 1983 map of simulated depth to the water table (fig. 41D) shows a depth of $0-10 \mathrm{ft}$ west of Reaches 3, 4A, and 4B1. The model results generally match the observed map of depth to water (fig. 8B) for these areas. However, as in 1981, the model simulates deeper water levels west of Reaches $2 \mathrm{~B}$ and 4B2 in the areas poorly constrained by observation wells.

The 1988 simulated water-table elevation map (fig. 41E) represents a Dry year preceded by a Dry year. The simulated water table declined relative to 1983 and is similar to that for 1981. A depth to water of 5-15 ft is simulated west of Reaches
3, 4A, and 4B1 (fig. 41F). The model results generally match the observed map of depth to water (fig. 8C) for these areas. As for 1981 and 1983, the model simulates deeper water levels west of Reaches $2 \mathrm{~B}$ and $4 \mathrm{~B} 2$ in the areas poorly constrained by observation wells.

The 1991 simulated water-table elevation map (fig. 41G) represents conditions near the end of a multi-year drought. The simulated water table declined by 10-20 ft relative to 1988 in most areas and by about $5 \mathrm{ft}$ in the shallow groundwater areas (west of Reaches 3, 4A, and 4B1). It is likely that groundwater levels remained relatively high in these areas because the local irrigation districts have firm surface-water rights and do not need to rely as much on groundwater pumping to meet agricultural demands. The simulated depth to water west of Reaches 3, 4A, and 4B1 is 10-20 ft (fig. 41H). The model results generally match the observed map of depth to water (fig. 8D) in these areas.

Comparison between the simulated and observed maps of depth to water for these 4 years demonstrates the model reasonably matches observed values in most areas where data are present. The SJRRPGW matches the observed depth to water table particularly well in the shallow groundwater areas west of Reaches 3, 4A, and 4B1. The simulated and observed 1983 and 1991 maps of depth to the water table show a shallower water table in 1983 (wet conditions) and a deeper water table in 1991 (dry conditions).

An interactive animation displaying the simulated elevation of the water table for 1961-2003 is available (http:// pubs.usgs.gov/sir/2014/5148/downloads/sir2014-5148_GWE. $s w f)$. A similar interactive animation displaying the simulated depth to the water table is available (http://pubs.usgs.gov/ sir/2014/5148/downloads/sir2014-5148_D2GW.swf). These animations show how the water-table elevation and depth to the water table change during the simulation period throughout the study area. Seasonal fluctuations, particularly in areas dependent on agricultural groundwater pumping, are clearly evident in the water-table elevation animation. In the animation of depth to the water table, the effects of stream seepage are evident, such as during April 1983 and January 1997, where the depth to water decreases in response to increased streamflow. During dry periods, such as November 1977 or October 1992, the water table drops to more than $10 \mathrm{ft}$ below land surface throughout most of the study area.

\section{Maps of Groundwater and Surface-Water Interaction}

The average simulated interaction of groundwater and surface water for the SJRRPGW simulation period (19612003 ) is shown in figure 42. The largest amounts of stream seepage occur in Reaches 1, 2A, and 3, which are sections of the San Joaquin River that have flow most of the time. At the downstream end of Reach 5, the San Joaquin River, as simulated, transitions from a stream that on average loses water (recharges groundwater) to a stream that on average gains 
Table 22. San Joaquin River Restoration Program groundwater flow model (SJRRPGW) monthly average streamflow budget, San Joaquin Valley, California.

[All streamflow budget terms are in acre-feet per month.]

\begin{tabular}{|c|c|c|c|c|c|c|c|c|}
\hline Year & $\begin{array}{c}\text { San Joaquin } \\
\text { River } \\
\text { inflow }\end{array}$ & $\begin{array}{l}\text { Merced } \\
\text { River } \\
\text { inflow }\end{array}$ & $\begin{array}{l}\text { Kings } \\
\text { River } \\
\text { inflow }\end{array}$ & $\begin{array}{c}\text { Other } \\
\text { streams } \\
\text { inflow }\end{array}$ & $\begin{array}{l}\text { Runoff } \\
\text { to } \\
\text { streams }\end{array}$ & $\begin{array}{c}\text { Net } \\
\text { diversions }\end{array}$ & $\begin{array}{l}\text { Net stream } \\
\text { seepage to } \\
\text { groundwater }\end{array}$ & $\begin{array}{c}\text { San Joaquin } \\
\text { River } \\
\text { outflow }\end{array}$ \\
\hline & + & + & + & + & + & - & - & $=$ \\
\hline 1 & 34,100 & 37,100 & 16,900 & 48,600 & 12,600 & -600 & 31,700 & 118,300 \\
\hline 2 & 55,200 & 52,100 & 20,200 & 71,800 & 9,600 & 500 & 41,800 & 166,700 \\
\hline 3 & 63,500 & 50,800 & 30,600 & 51,500 & 4,400 & 8,800 & 36,000 & 156,100 \\
\hline 4 & 79,500 & 50,700 & 40,300 & 32,200 & 1,900 & 8,800 & 39,900 & 155,900 \\
\hline 5 & 74,700 & 54,700 & 47,400 & 9,700 & 1,500 & 14,400 & 36,000 & 137,600 \\
\hline 6 & 64,400 & 45,600 & 33,300 & 6,100 & 2,800 & 10,700 & 40,300 & 101,100 \\
\hline 7 & 37,300 & 27,700 & 16,000 & 5,200 & 3,600 & $-2,700$ & 39,600 & 53,000 \\
\hline 8 & 12,800 & 15,400 & 1,800 & 3,600 & 3,700 & $-18,600$ & 31,600 & 24,200 \\
\hline 9 & 11,900 & 18,600 & 1,200 & 1,700 & 2,800 & $-5,400$ & 17,600 & 24,000 \\
\hline 10 & 8,700 & 25,000 & 2,500 & 1,900 & 900 & $-4,100$ & 14,800 & 28,300 \\
\hline 11 & 9,500 & 18,800 & 5,700 & 3,200 & 5,300 & $-2,100$ & 16,300 & 28,300 \\
\hline 12 & 14,900 & 26,100 & 9,000 & 18,700 & 9,400 & -600 & 21,200 & 57,700 \\
\hline
\end{tabular}

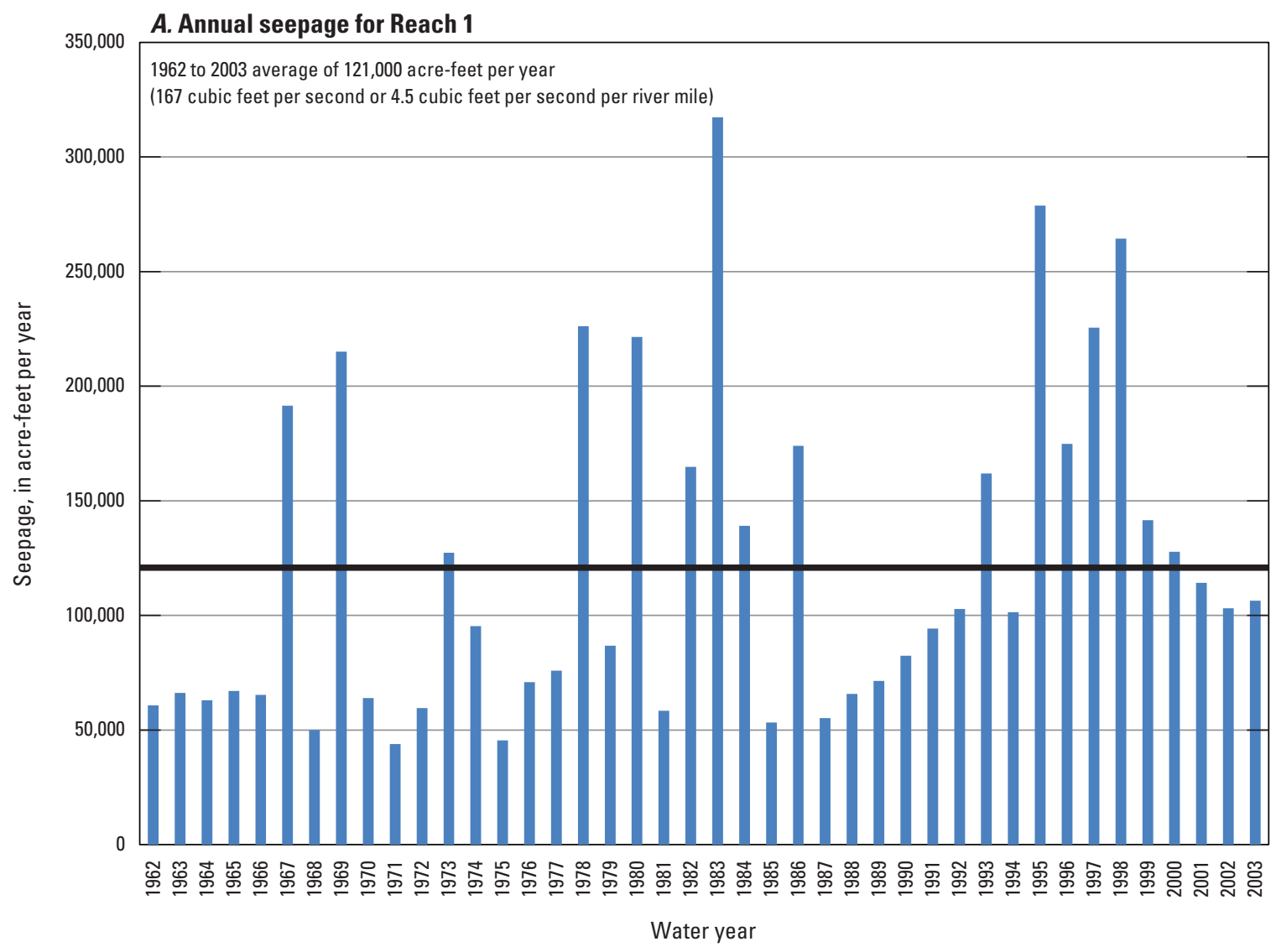

Figure 40. San Joaquin River Restoration Program groundwater flow model (SJRRPGW) annual seepage for San Joaquin River Management Reaches, San Joaquin Valley, California: $A$, Reach 1; $B$, Reach 2; $C$, Reach 3; D, Reach 4; E, Reach 5. 


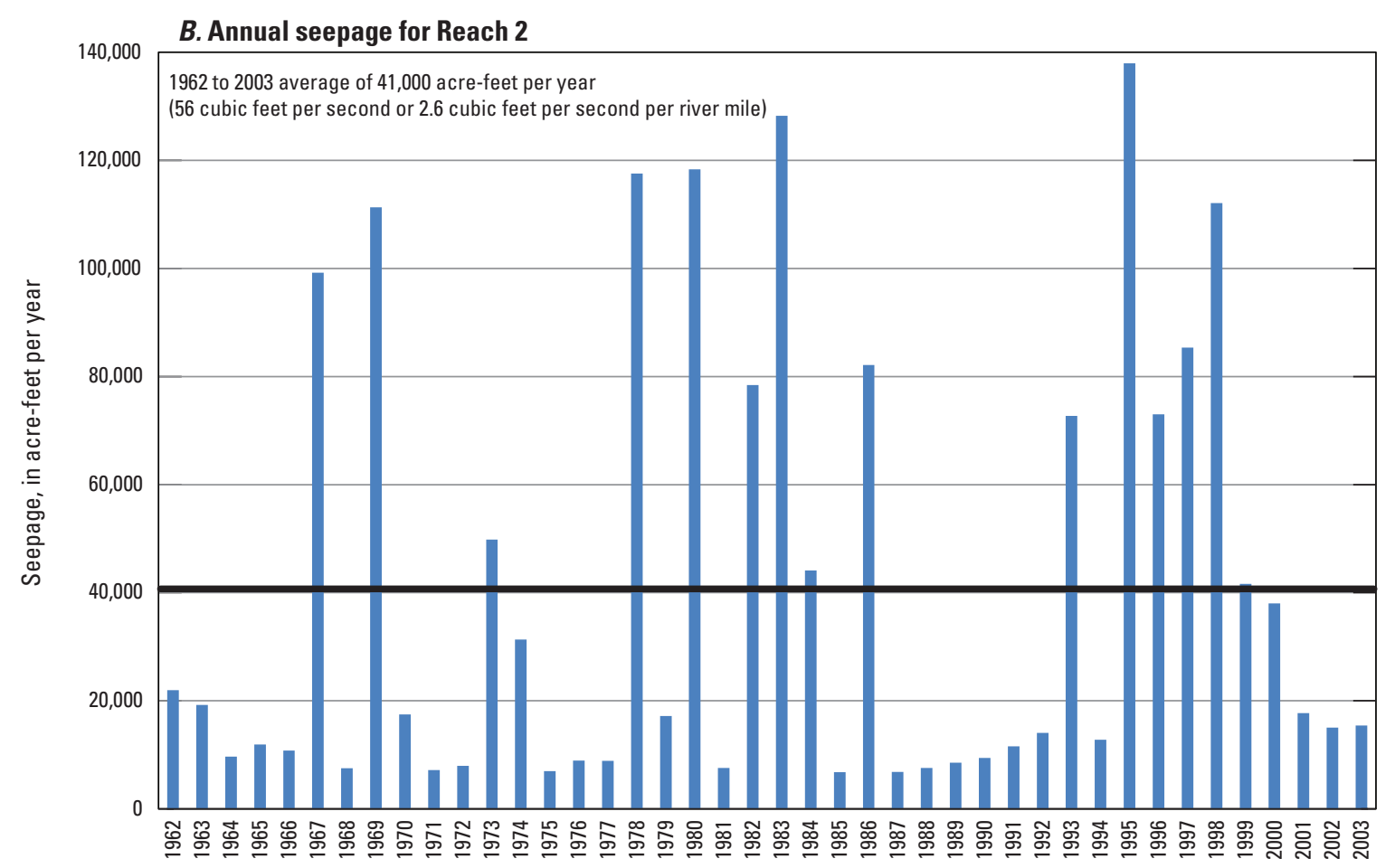

Water year

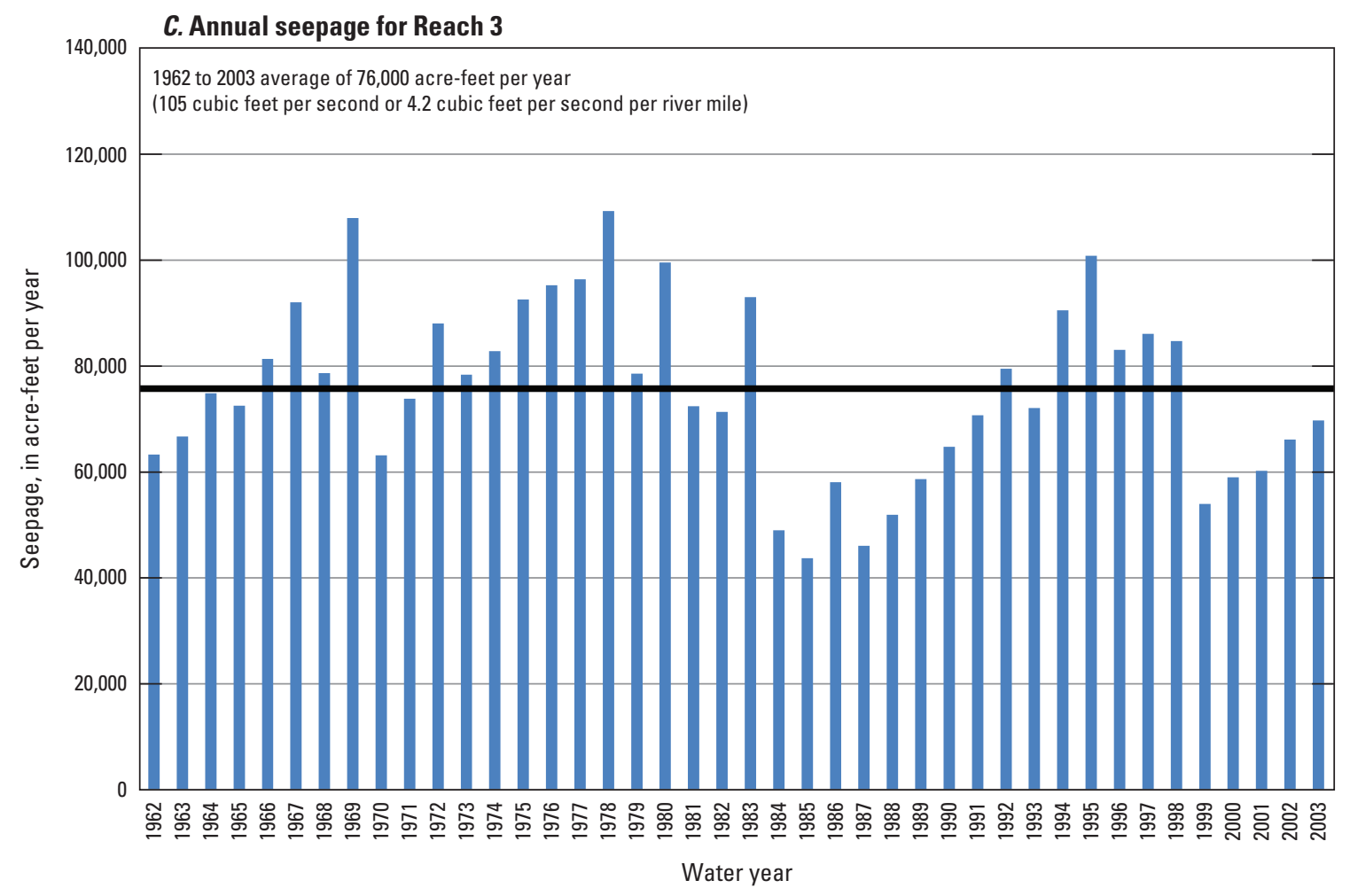

Figure 40. - Continued 

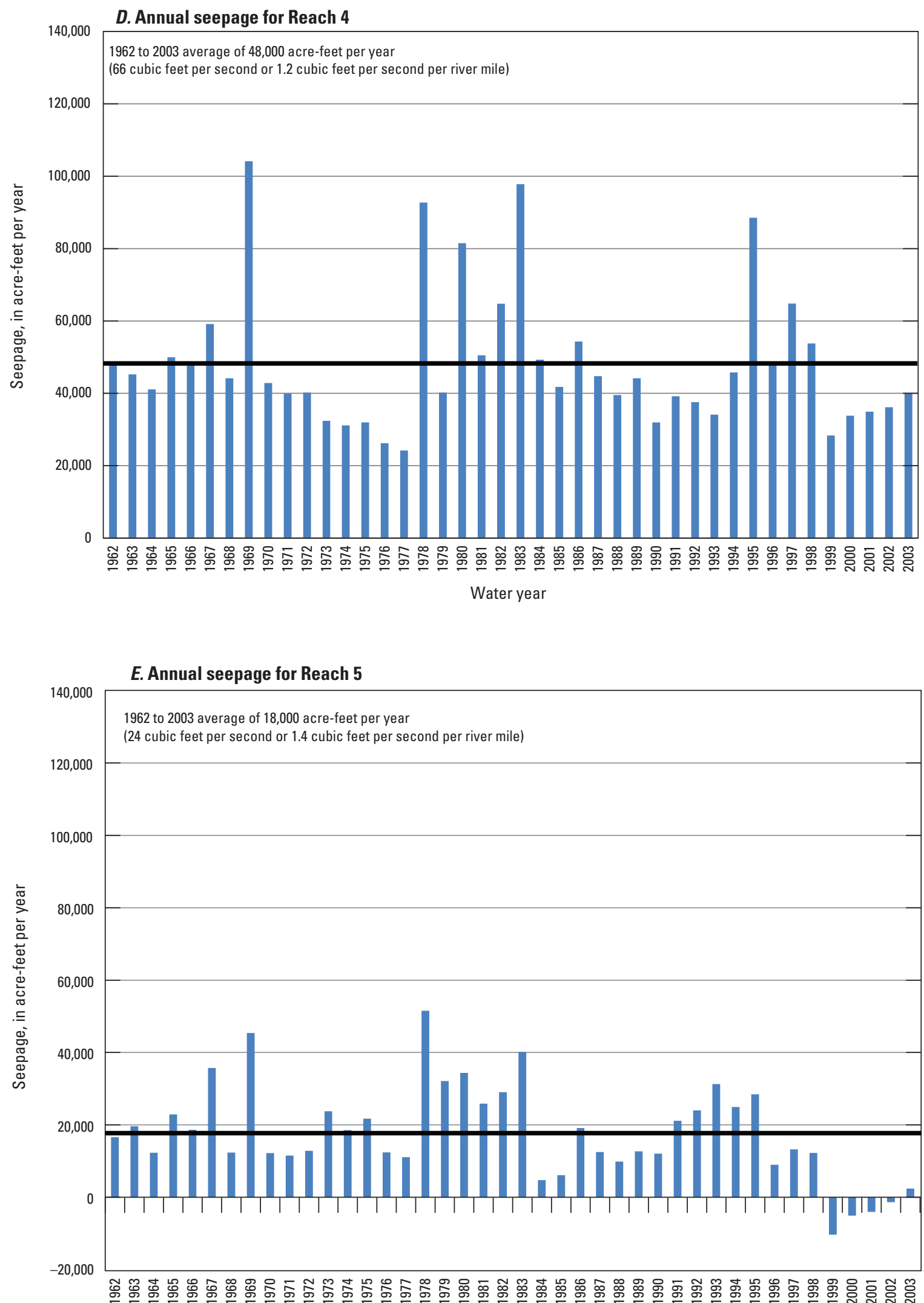

Water year

Figure 40. - Continued 
$\boldsymbol{A}$

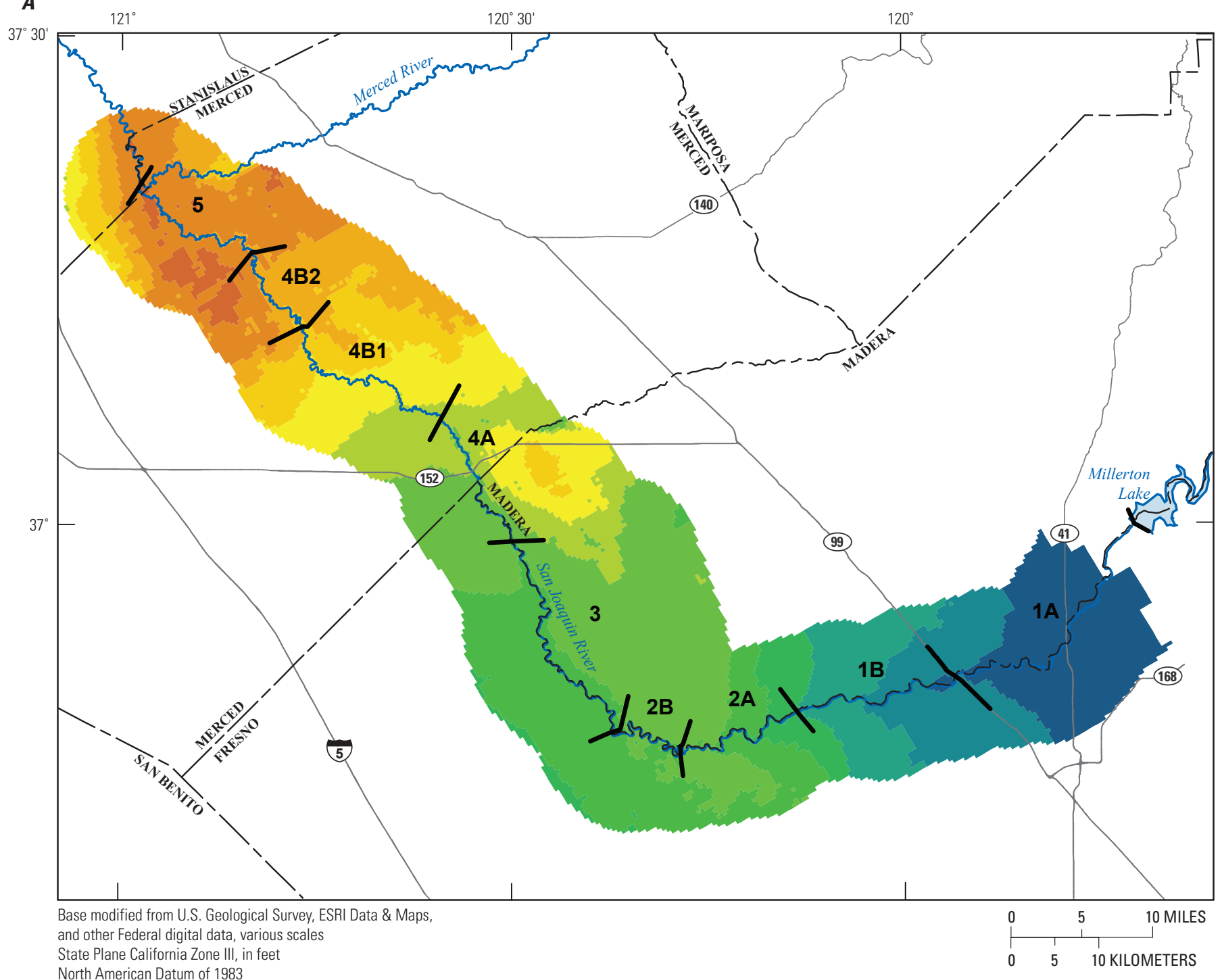

State Plane California Zone III, in feet

EXPLANATION

\begin{tabular}{|c|c|c|c|}
\hline \multicolumn{2}{|c|}{ Groundwater elevation } & 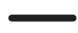 & San Joaquin River Restoration \\
\hline$\leq 40$ & $>100$ to 120 & & Program reach divide \\
\hline$>40$ to 50 & $>120$ to 140 & & Major river \\
\hline$>50$ to 60 & $>140$ to 160 & & Road \\
\hline$>60$ to 70 & $>160$ to 180 & & County boundary \\
\hline$>70$ to 80 & $>180$ to 200 & & \\
\hline$>80$ to 90 & $>200$ to 300 & & \\
\hline$>90$ to 100 & $>300$ & & \\
\hline
\end{tabular}

Figure 41. San Joaquin River Restoration Program groundwater flow model (SJRRPGW)-simulated groundwater elevation and depth to water table, San Joaquin Valley, California: $A$, Fall 1981 simulated groundwater elevation; $B$, Fall 1981 simulated depth to water table; $C$, Fall 1983 simulated groundwater elevation; $D$, Fall 1983 simulated depth to water table; $E$, Fall 1988 simulated groundwater elevation; F, Fall 1988 simulated depth to water table; G, Fall 1991 simulated groundwater elevation; $H$, Fall 1991 simulated depth to water table. 


\section{B}

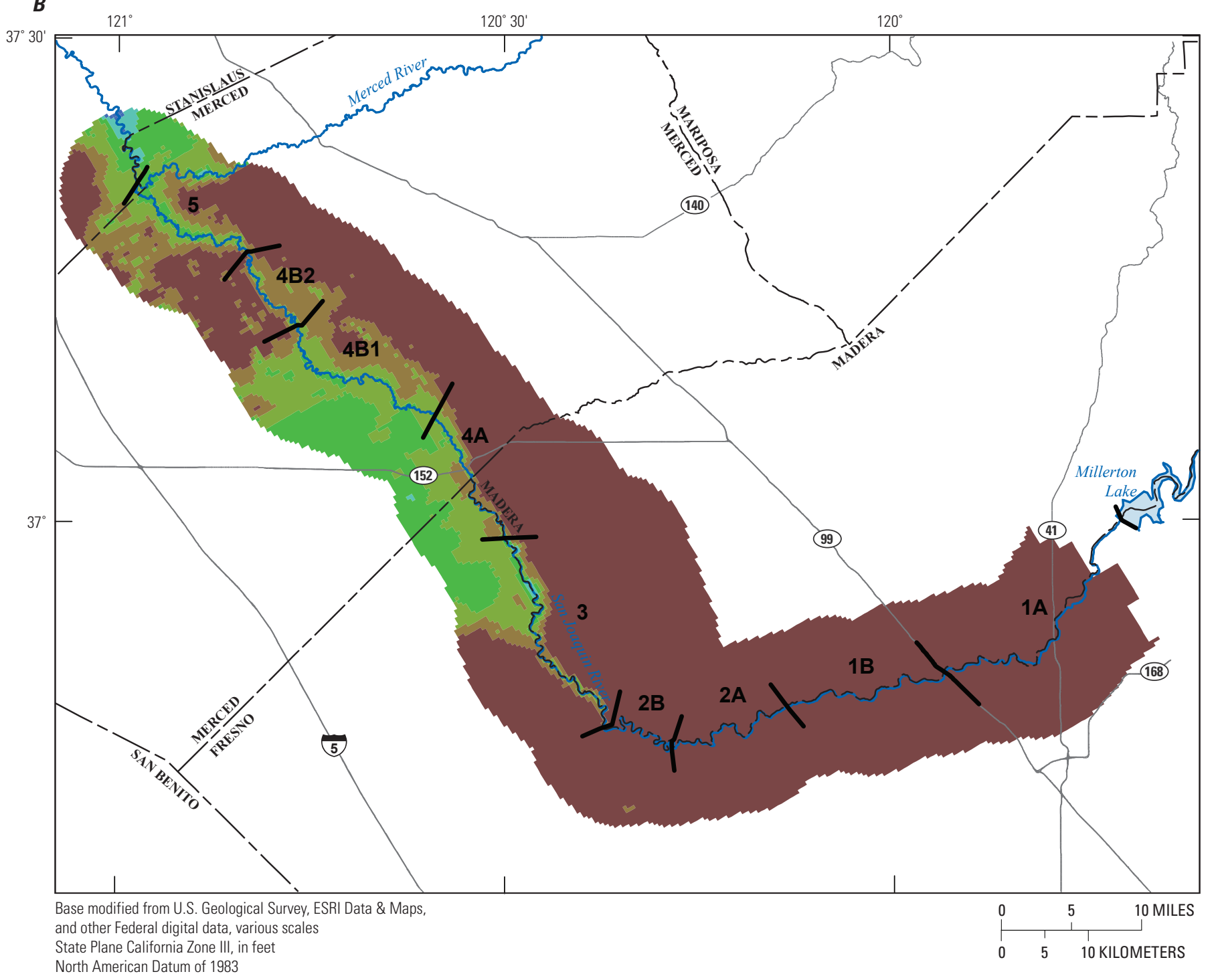

EXPLANATION

\begin{tabular}{|c|c|c|}
\hline Depth to groundwater & $\longrightarrow$ & $\begin{array}{l}\text { San Joaquin River Restoration } \\
\text { Program reach divide }\end{array}$ \\
\hline$\leq 0$ & & 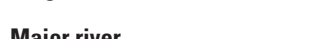 \\
\hline$>0$ to 5 & & וIT) \\
\hline$>5$ to 10 & & Road \\
\hline$>10$ to 15 & --- & County boundary \\
\hline$>15$ to 20 & & \\
\hline$>20$ & & \\
\hline
\end{tabular}

Figure 41. - Continued 


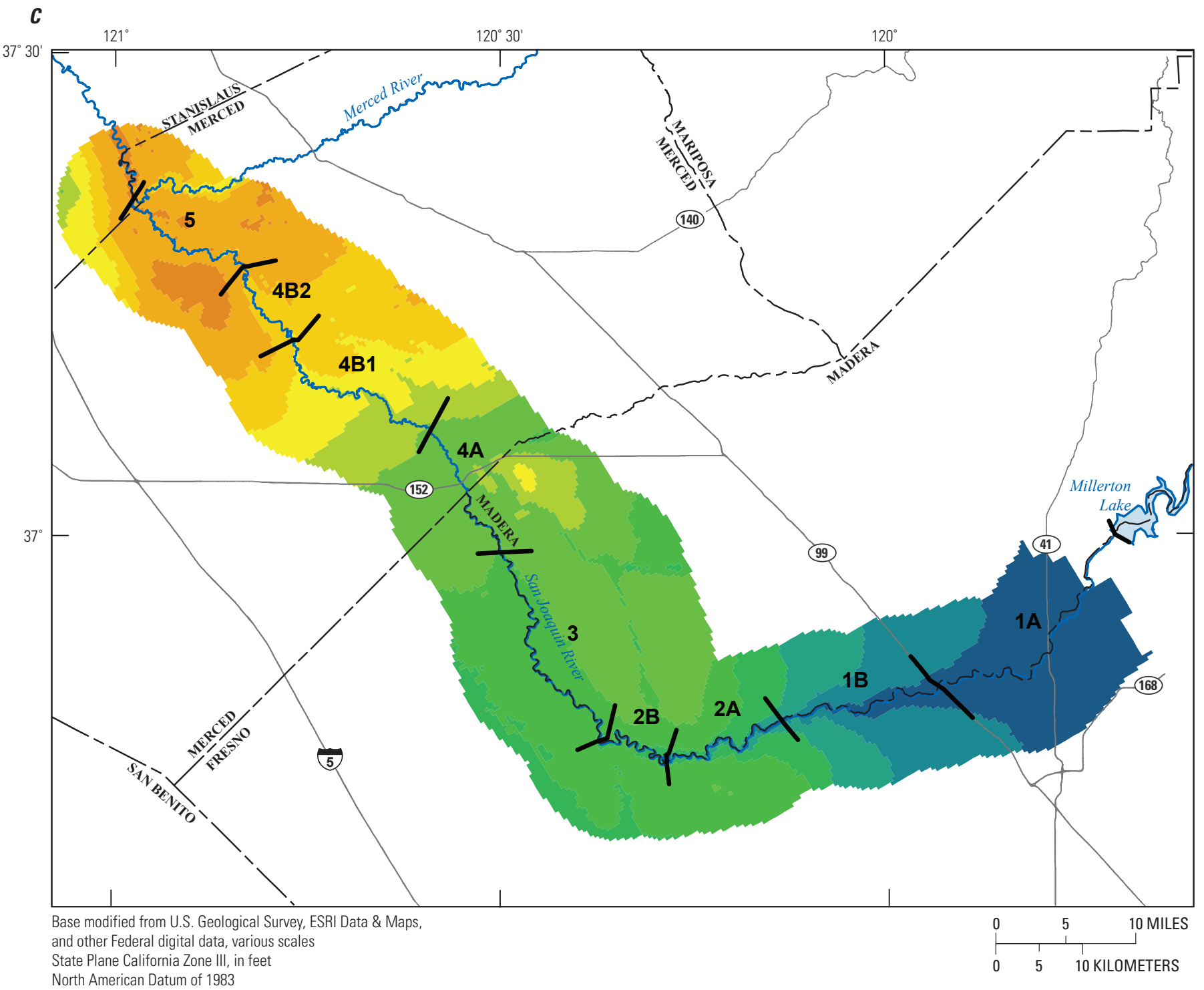

EXPLANATION

\begin{tabular}{|c|c|c|c|}
\hline \multicolumn{2}{|c|}{ Groundwater elevation } & $\longrightarrow$ & San Joaquin River Restoration \\
\hline$\leq 40$ & $>100$ to 120 & & Program reacn aivide \\
\hline$>40$ to 50 & $>120$ to 140 & & IVIajor river \\
\hline$>50$ to 60 & $>140$ to 160 & & Road \\
\hline$>60$ to 70 & & & County boundary \\
\hline$>70$ to 80 & $>180$ to 200 & & \\
\hline$>80$ to 90 & $>200$ to 300 & & \\
\hline$>90$ to 100 & $>300$ & & \\
\hline
\end{tabular}

Figure 41. - Continued 
D

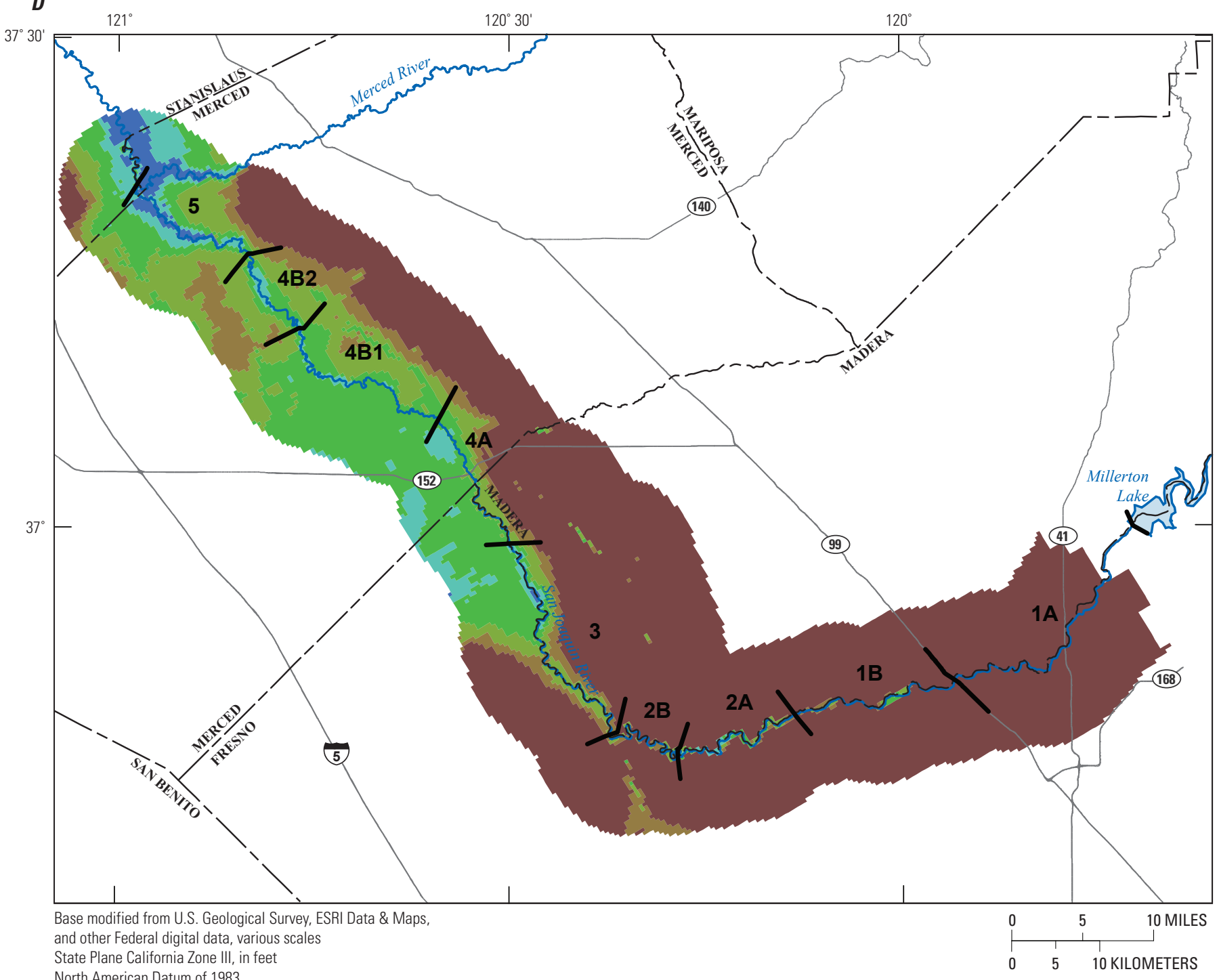

State Plane California Zone III, in feet

North American Datum of 1983

EXPLANATION

\begin{tabular}{|lll}
\hline Depth to groundwater & $-\begin{array}{l}\text { San Joaquin River Restoration } \\
\text { Program reach divide }\end{array}$ \\
$\leq 0$ & - & Major river \\
\hline & $>0$ to 5 & Road \\
\hline$\square$ & $>5$ to 10 & County boundary \\
\hline$\square$ & $>10$ to 15 \\
\hline & $>15$ to 20 \\
\hline & $>20$
\end{tabular}

Figure 41. - Continued 


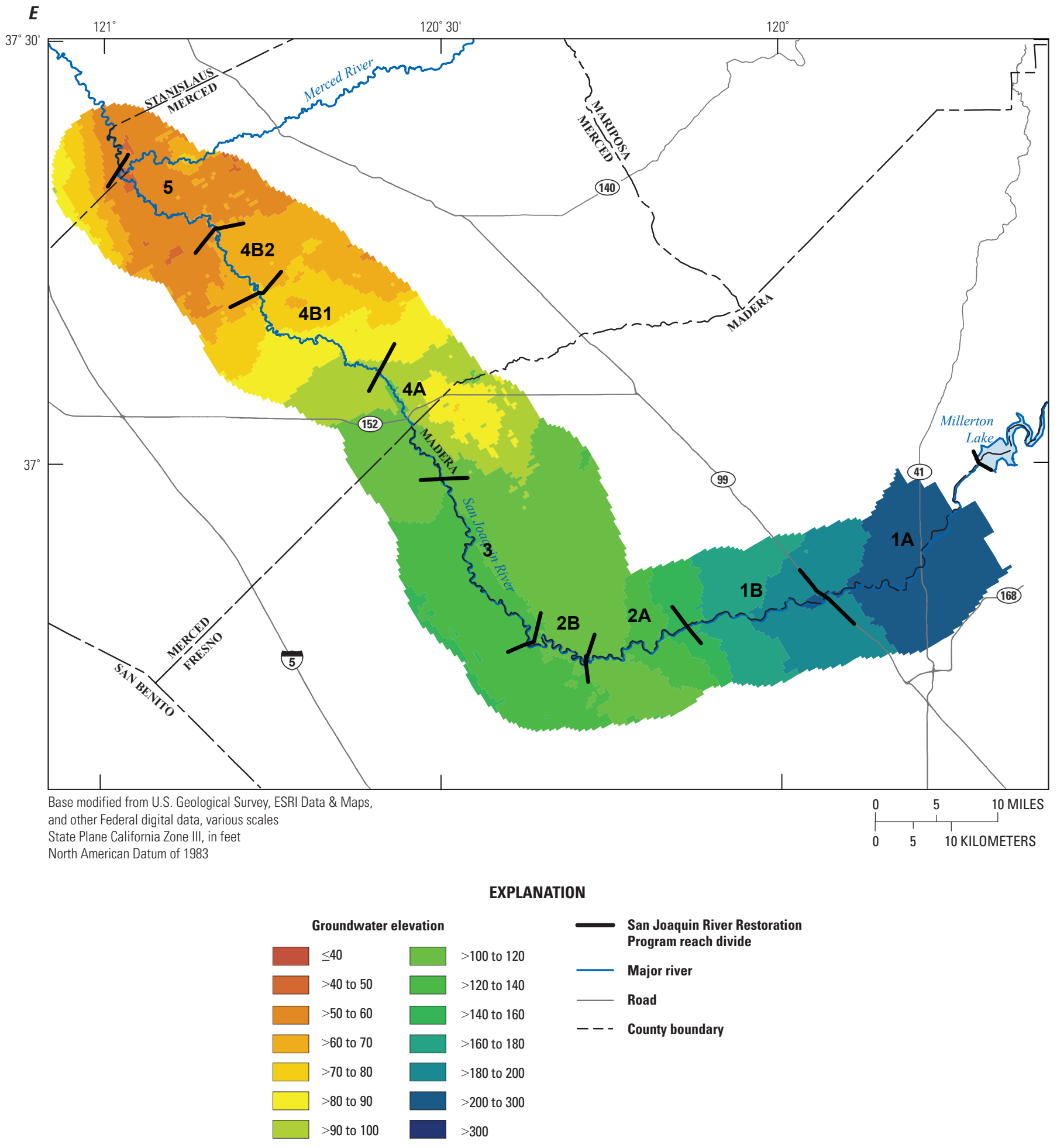

Figure 41. - Continued 


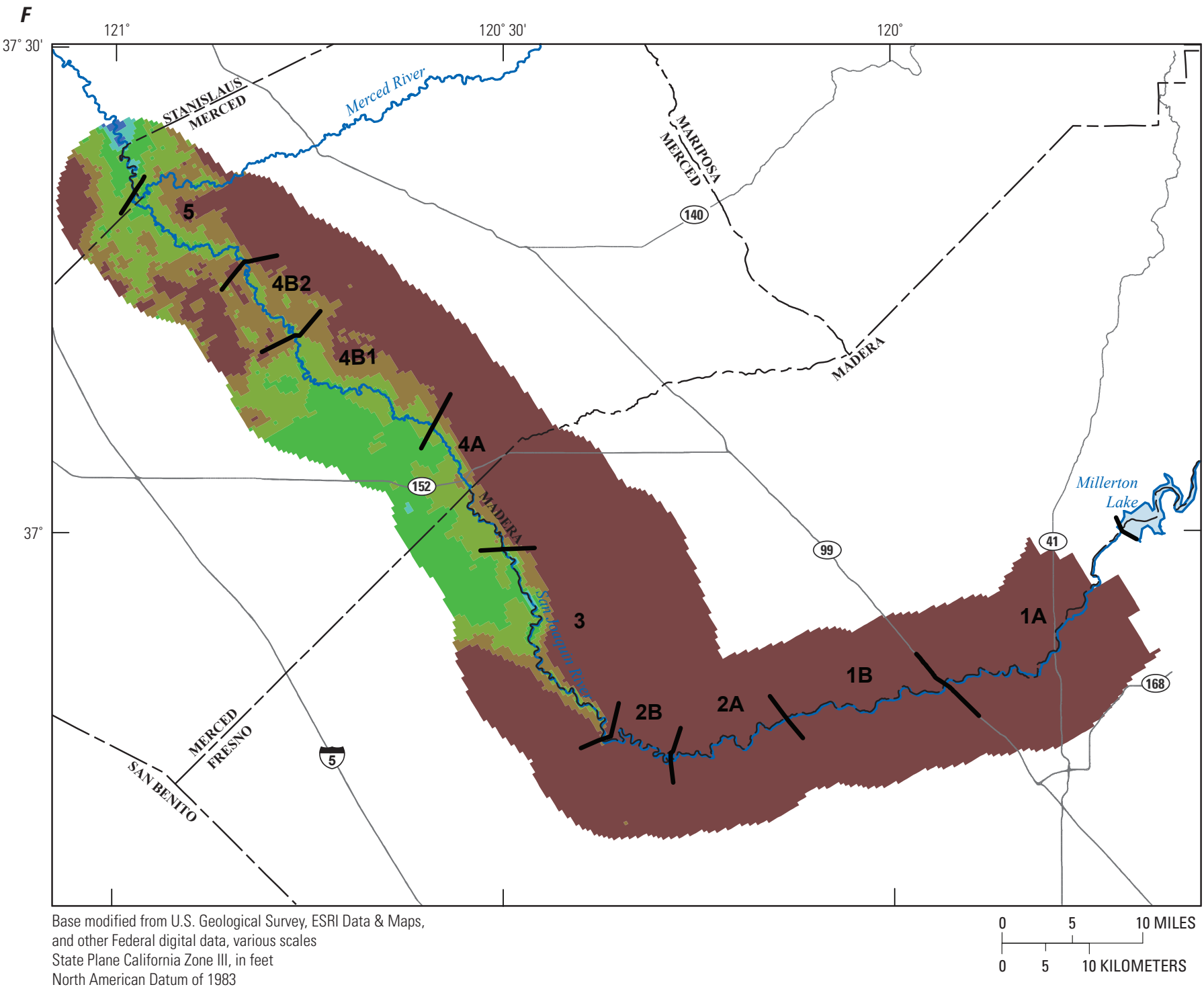

EXPLANATION

\begin{tabular}{|c|c|c|}
\hline Depth to groundwater & $\longrightarrow$ & $\begin{array}{l}\text { San Joaquin River Restoration } \\
\text { Program reach divide }\end{array}$ \\
\hline$\leq 0$ & & \\
\hline$>0$ to 5 & & \\
\hline$>5$ to 10 & & Road \\
\hline & --- & County boundary \\
\hline$>10$ to 15 & & \\
\hline$>15$ to 20 & & \\
\hline$>20$ & & \\
\hline
\end{tabular}

Figure 41. - Continued 
G

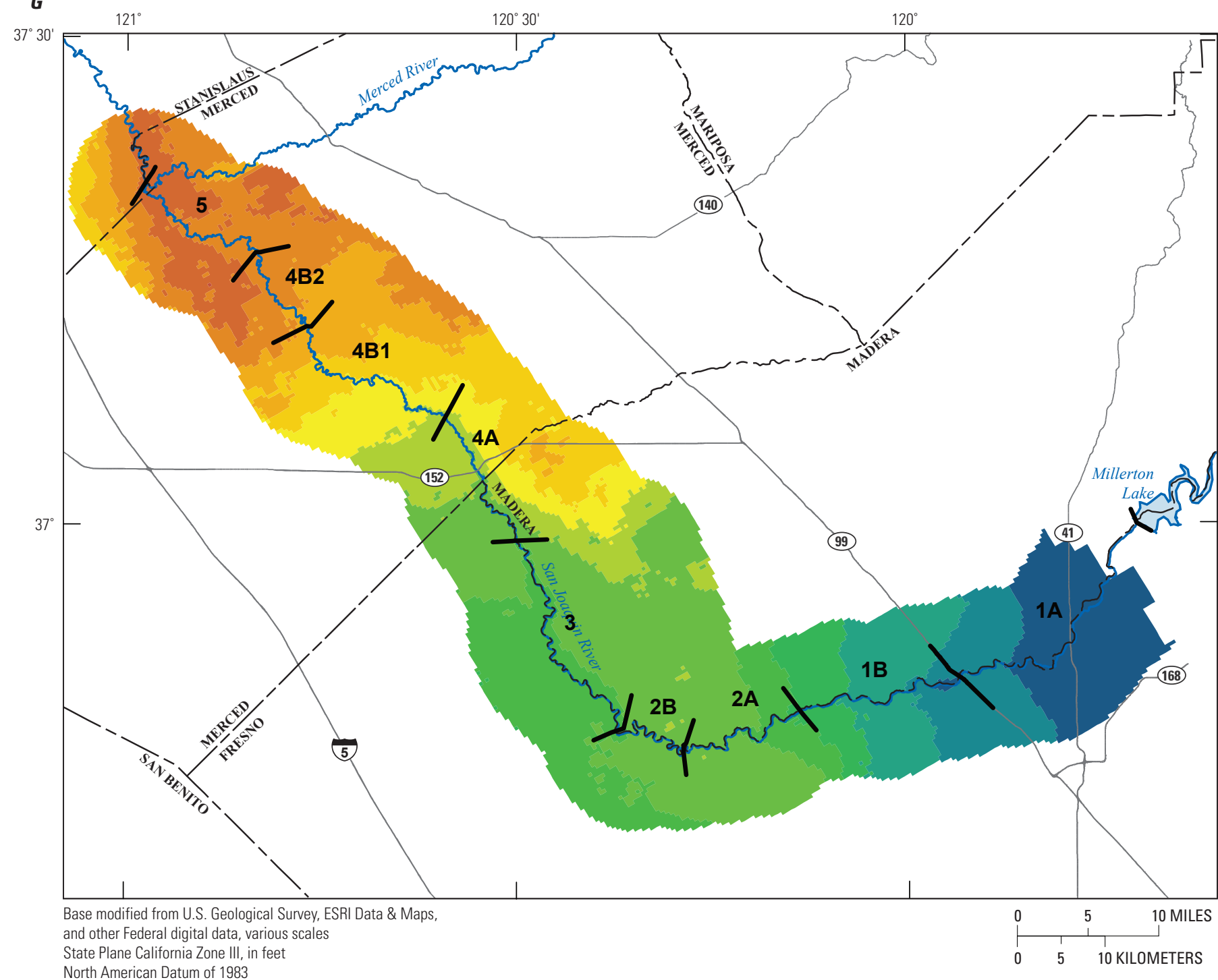

State Plane California Zone III, in feet
North American Datum of 1983

EXPLANATION

\begin{tabular}{|c|c|c|c|}
\hline \multicolumn{2}{|c|}{ Groundwater elevation } & 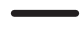 & $\begin{array}{l}\text { San Joaquin River Restoration } \\
\text { Program reach divide }\end{array}$ \\
\hline$\leq 40$ & $>100$ to 120 & & riograili reacir uiviue \\
\hline$>40$ to 50 & $>120$ to 140 & & 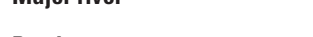 \\
\hline$>50$ to 60 & $>140$ to 160 & & nuau \\
\hline$>60$ to 70 & $>160$ to 180 & & County boundary \\
\hline$>70$ to 80 & $>180$ to 200 & & \\
\hline$>80$ to 90 & $>200$ to 300 & & \\
\hline$>90$ to 100 & $>300$ & & \\
\hline
\end{tabular}

Figure 41. - Continued 


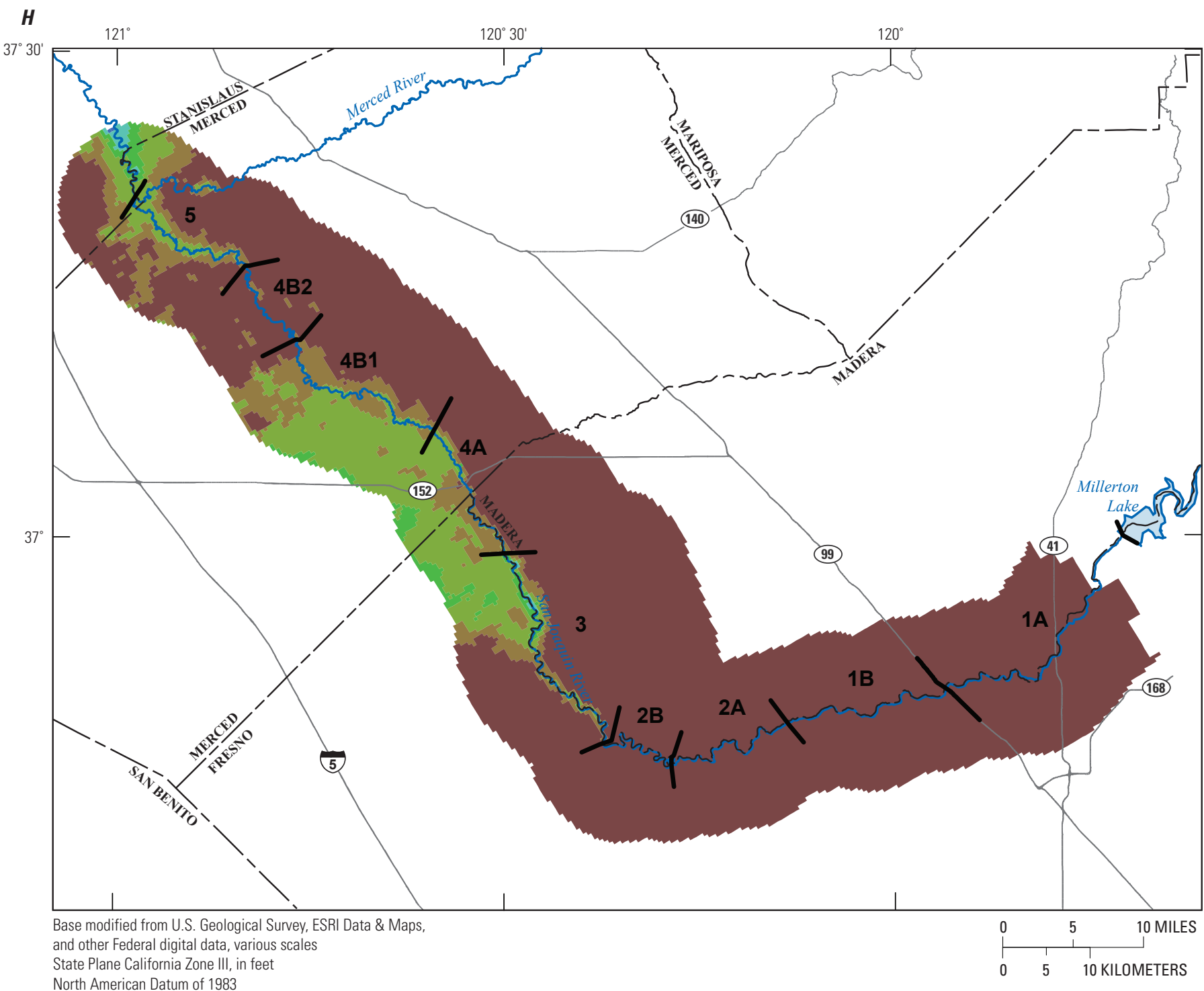

EXPLANATION

\begin{tabular}{|lll} 
Depth to groundwater & $-\begin{array}{l}\text { San Joaquin River Restoration } \\
\text { Program reach divide }\end{array}$ \\
$\leq 0$ & - & Major river \\
\hline$\square$ & -0 to 5 & Road \\
\hline$\square$ & $>5$ to 10 & County boundary \\
\hline$\square$ & $>10$ to 15 \\
\hline & $>15$ to 20 \\
\hline &
\end{tabular}

Figure 41. - Continued 


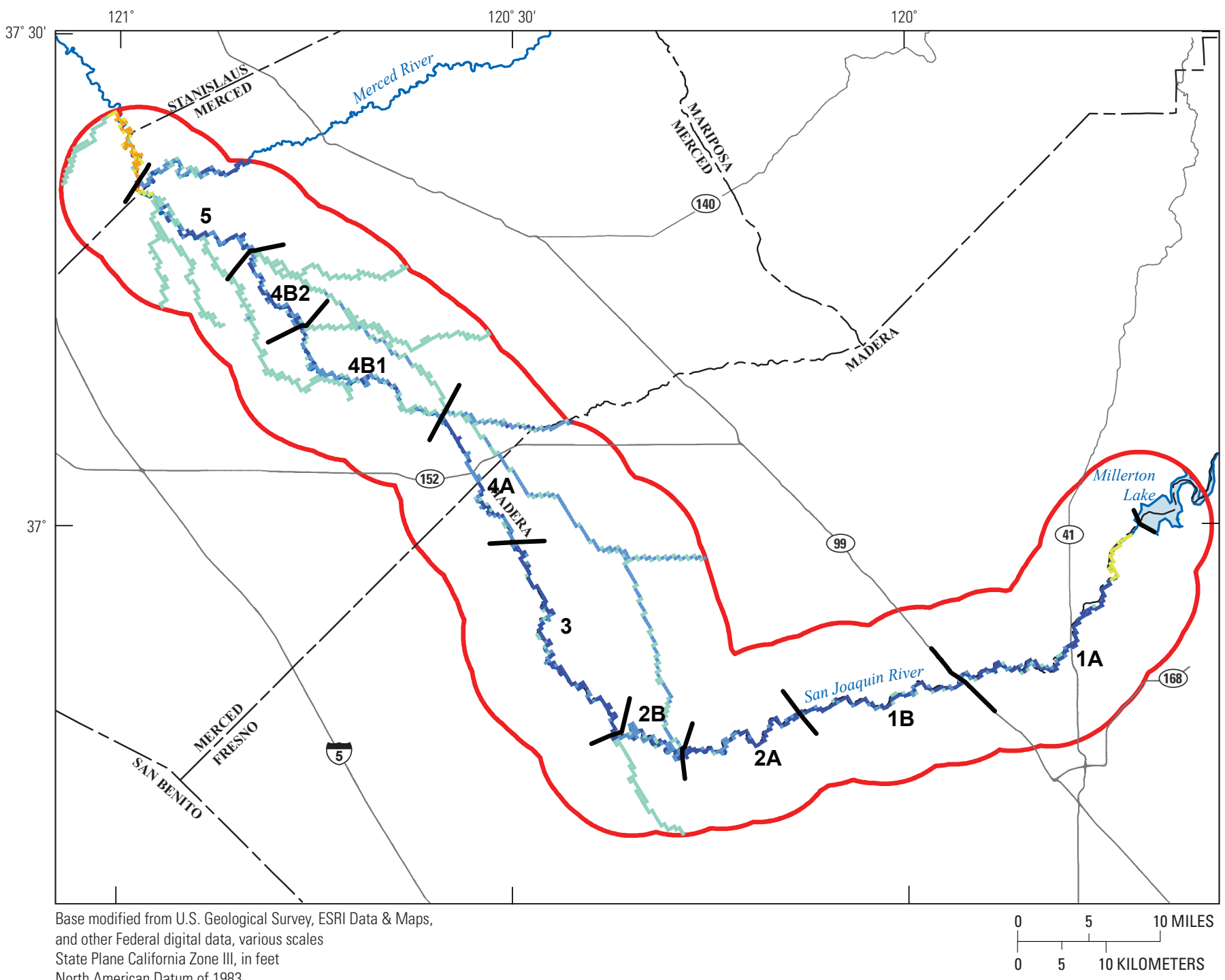

EXPLANATION

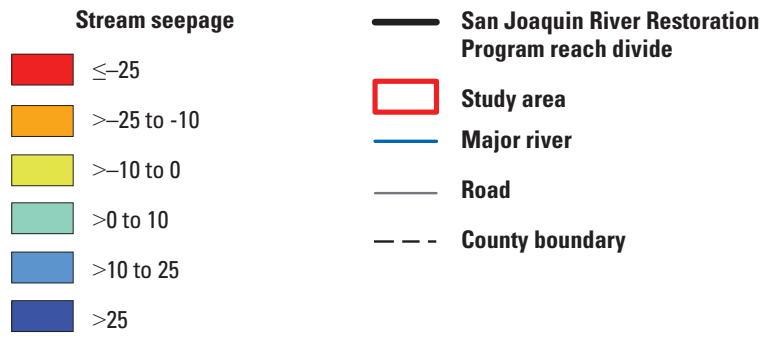

Stream seepage by model cell averaged over simulation period (1961 to 2003) Units in acre-feet per month

Positive seepage values indicate streamflow loss to groundwater

Negative seepage values indicate streamflow gain from groundwater

Figure 42. San Joaquin River Restoration Program groundwater flow model (SJRRPGW) average groundwater and surface-water interaction, San Joaquin Valley, California. 
water from groundwater inflow. The upper section of Reach $1 \mathrm{~A}$ has zero simulated groundwater seepage because the model cells below the stream are outside the groundwater basin and are, therefore, not active for the simulation of groundwater. The simulated gaining and losing segments generally are consistent with previous studies.

An interactive animation displaying the simulated groundwater and surface-water interactions for all 510 stress periods is available (http://pubs.usgs.gov/sir/2014/5148/ downloads/sir2014-5148_StreamSeepage.swf). This animation shows how the interaction of groundwater and surface water changes throughout the simulation period. For example, although most simulated streams lose flow to groundwater on average (fig. 42), many simulated streams gain flow from the aquifer system during some months. For example, 1984 was a Normal-Wet year and 1997 was a Wet year; however, February 1984 and March 1997 were relatively dry months within these years. During these months, although streamflows were reduced, groundwater elevations remained high, and Reaches 3, 4, and 5 of the San Joaquin River switched from being losing to gaining. These simulated results are consistent with previous studies that indicate there can be a net river loss or gain in Reaches 3, 4, and 5 depending on the local and regional hydraulic gradients (Deverel, 2005). A primary purpose of the model is to estimate river seepage in areas with existing irrigation drainage problems (between Mendota Pool and the confluence with the Merced River-Reaches 3, 4, and 5); therefore, the performance of the SJRRPGW in this area is particularly important.

\section{Model Limitations and Appropriate Use}

The SJRRPGW is an approximate mathematical representation of the physical conditions in the field. These approximations and associated assumptions contribute to the inability of the model to fully replicate the historical observations at all locations at all times. It is important to understand these limitations before SJRRPGW is applied to the evaluation of SJRRP water-management alternatives or to other uses.

The SJRRPGW represents the physical system by a series of mathematical approximations. Because the physical system is inherently complex, it is not possible to develop a complete mathematical model of the system without introducing certain simplifying assumptions. As with most groundwater models, the SJRRPGW solves for average conditions within each model cell, which for SJRRPGW are 0.25 -mi by $0.25-\mathrm{mi}$ laterally. Therefore, the SJRRPGW is best used for simulating hydrologic responses on a regional scale and not as well suited for the evaluation of effects over areas smaller than a few square miles.
The input data used in the SJRRPGW represent the best information available during the study period at the time of the study. The input data for each model component are not equally available, and assumptions were made during the model-development process regarding missing data. For example, agricultural pumping data, one of the most critical stresses affecting groundwater elevations in the study area, are not available and were estimated using the FMP2. Likewise, urban pumping data also were estimated and were done so on the basis of land use, which was temporally updated only five times during the simulation period. All pumping was simulated using virtual wells because data on the location and properties of the production wells are not available.

The general-head boundary conditions are estimated from the CVHM. Care should be exercised when using the SJRRPGW to estimate the hydrologic effects of projects that extend beyond the model boundary.

For some months of the simulation, excess surface water was delivered to some subregions beyond what the FMP2 estimated for agricultural demand. This excess surface water is likely due to errors in the FMP2 estimation of agricultural demand, errors in the surface-water delivery data (either in raw data or in how it was incorporated into the model), preirrigation not simulated by FMP2, or actual deliveries made to irrigation canals that are not then diverted to the fields. This excess water is currently not accounted for in the SJRRPGW and could lead to an underestimation of streamflow, stream seepage to groundwater, and percolation to groundwater.

The accuracy of the model is dependent on the spatial and temporal availability of observation data. Most notably, quantitative data on groundwater and surface-water interaction are not available (although the model was consistent with qualitative studies). In addition, groundwater elevation and streamflow data are not available for all locations and all periods. On the basis of these limitations, the SJRRP is best suited for estimating the hydraulic response to restoration flows and seepage management actions in areas where the model simulates the groundwater levels and trends reasonably well. For example, SJRRPGW performance is best in the CCID South area, to the west of Reaches 3 and 4A; for this area, the model is expected to predict future system behavior reasonably well.

Though unconfined groundwater flow occurs in the water table, confined groundwater flow is simulated in all the layers in the model to avoid numerical instability and long model execution times. The model properly represents unconfined aquifer storage by using a value of specific yield for the uppermost active cells. However, by simulating confined flow in all layers, the saturated thickness and transmissivity are fixed and are not a function of groundwater head. Model cells where the simulated groundwater elevation is always below the cell bottom were made inactive during calibration to avoid overestimation of saturated thickness of the aquifer. However, it is possible that with SJRRP flow releases, the water table in some areas may rise above the highest active model cells. In 
these cases, the SJRRPGW may underestimate the transmissivity of the aquifer.

\section{Future Work}

To support planned future work, the SJRRPGW can be used to provide preliminary evaluations of the potential effects of SJRRP restoration flows on agricultural lands with existing drainage problems. Planned future work includes the development of an "existing conditions" baseline by using the SJRRPGW to represent what conditions would be without the SJRRP. Plans include the simulation of several different scenarios of SJRRP flow-release alternatives to determine the effects of the SJRRP. Also, development of a "future conditions" baseline is planned in order to estimate water-table conditions during future conditions (such as those that may result from climate change or future land use).

The model is expected to be used as a decision support tool in the evaluation of several proposed seepage mitigation projects. Potential projects to be simulated include construction of slurry walls to block subsurface water movement, installation of drainage ditches or interceptor lines to capture shallow groundwater, and installation and pumping of groundwater wells or increased pumping of existing agricultural groundwater wells to lower the regional groundwater table.

\section{Model Enhancements}

Several future model enhancements planned for the SJRRPGW are discussed in this section. In addition to the enhancements discussed below, the model would be updated with any new input data that become available. These enhancements will improve the capability of the SJRRPGW to accurately simulate the hydrologic system.

The simulation period for the SJRRPGW is from April 1961 to September 2003, coinciding with the CVHM simulation period. A planned future enhancement to the model would be to extend the period to the 2013. The extended model would include the interim flows released for the project starting in 2009. Inclusion of these flows would allow calibration of the model under a set of stresses similar to those the model would operate under when used to make future predictions. Over 200 SJRRP observation wells were installed and monitored by Reclamation beginning in the spring of 2008, and extending the model would allow for use of these highfrequency, high-quality data in model calibration.

The SJRRPGW currently uses monthly stress periods. When using the model to simulate the SJRRP surface-water releases, it would be necessary to average the releases over these monthly time steps. A planned future enhancement would be to subdivide the stress periods into semi-monthly or weekly stress periods to allow for more accurate simulation of the SJRRP surface-water releases.

Confined groundwater flow is simulated in all layers in the SJRRPGW. A planned future enchantment would be to simulate all the model layers as convertible between confined and unconfined groundwater flow. The associated numerical instabilities could be mitigated by using the Newton (NWT) Solver Package in MODFLOW-NWT (Niswonger and others, 2011). NWT was developed for solving models that would otherwise fail to converge because of the drying and rewetting of unconfined model cells. The USGS is currently revising NWT for broader compatibility with other MODFLOW packages and processes, including those used in the SJRRPGW.

The SJRRPGW uses heads extracted from the CVHM as general heads along the model boundary. The drawback to this approach is that the model cannot correctly simulate watermanagement scenarios if the effect of the scenario extends beyond the model boundary (more than $5 \mathrm{mi}$ from the San Joaquin River and bypass system). A planned future enhancement would be to embed the SJRRPGW within an updated version of the CVHM using MODFLOW-LGR (Mehl and Hill, 2005). Local Grid Refinement (LGR) allows two models to be coupled together and run simultaneously such that heads and flows are balanced at the interface between the two models. The USGS is revising MODFLOW-LGR for broader compatibility with other MODFLOW packages and processes, including those used in the SJRRPGW.

\section{Investigate Predictive Uncertainty of Simulated Stream Seepage}

The final calibrated parameter set represents just one of many parameter sets that could result in a reasonably calibrated model. Each such parameter set could lead to differences in the simulated seepage along the San Joaquin River. Planned future work involves investigating this uncertainty by using linear predictive uncertainty concepts and non-linear Pareto concepts. The uncertainty analysis would be used to determine which observation types and specific sites are most sensitive to changes in parameter values that influence stream seepage. Thus, this work could potentially identify areas where adding new observation data to the calibration dataset could help to narrow the predictive uncertainty range.

\section{Sensitivity to Transition-Probability Geostatistical Software Texture Realizations}

There were 100 equally probable realizations of the sediment-texture distribution developed for the study area. The first texture model was chosen arbitrarily for use in the SJRRPGW. The model could also be calibrated by using any of the other 99 realizations. Each realization would likely lead to a different parameter set and a different estimated seepage rate along the San Joaquin River. Evaluating the other texture realizations would help to address model uncertainty by providing a range of simulated seepage rates and the sensitivity of calibrated parameters to changes in the texture distribution. These simulations would also provide more information regarding the uncertainty of calibrated parameters compared to the simple linear confidence limits. By more fully exploring 
the range of calibration values for different sediment-texture distributions, uncertainty in aquifer properties and the resulting effects on other parameters of the model could be assessed.

\section{Summary and Conclusions}

The San Joaquin River Restoration Program (SJRRP) has a dual goal to restore the natural ecology along the San Joaquin River to a degree that restores and maintains native fish populations while avoiding reductions in surface water deliveries. Increased flows in the river, particularly during the spring salmon run, are a key component of the settlement agreement and the restoration effort. One potential consequence of these increased river flows, however, is the exacerbation of existing irrigation drainage problems through increased seepage from the river along losing reaches or reduced groundwater discharge to the river along gaining reaches.

The San Joaquin River Restoration Program groundwater flow model (SJRRPGW) is a hydrologic model developed as an analytical tool for use by the SJRRP and others to help evaluate potential water-management decisions. In addition to providing quantitative budget information about the groundwater flow system, the model can be used in many ways, including the following:

- To evaluate the potential effects of restoration flows on existing drainage problems.

- To compare the potential effectiveness of proposed seepage mitigation projects.

- To determine areas most susceptible to developing high water-table conditions during restoration flows.

- To evaluate the groundwater elevation thresholds developed as part of the SJRRP seepage management plan.

- To evaluate the spatial adequacy of the groundwater monitoring network and guide the SJRRP monitoring program in the location of future monitoring sites.

The SJRRPGW simulates a 1,300-square mile $\left(\mathrm{mi}^{2}\right)$ area within the San Joaquin Valley along a 150-mile (mi) reach of the San Joaquin River. The model simulates 42.5 years of historical hydrology from April 1961 to September 2003 on a monthly basis and utilizes datasets and hydrologic investigations from Federal (U.S. Geological Survey and U.S. Bureau of Reclamation), State (California Department of Water Resources), and local agencies (Central California Irrigation District). These datasets include ground-surface elevation, land-use and crop-related data, water supply and demand, well logs, groundwater levels, streamflows, and climate, soils, and aquifer properties.

The SJRRPGW is an integrated hydrologic model that simulates the surface-water hydrologic system, the groundwater aquifer system, and land-surface processes in a single model that uses the MODFLOW Farm Process. Simulated land-surface processes include precipitation, surface-water delivery, pumping of groundwater, plant uptake of shallow groundwater, plant evapotranspiration, on-farm efficiencies, precipitation and irrigation runoff, and percolation to groundwater. The MODFLOW SFR2 Package is used to simulate the surface-water system, which includes streamflow for the San Joaquin River, the San Joaquin River flood-control bypass system, and eight major tributaries. The MODFLOW HUF Package is used to represent a multi-layered aquifer system above the Corcoran Clay with properties defined by using a sediment-texture model developed using transitionprobability geostatistics.

The SJRRPGW was calibrated against historically observed groundwater levels at 133 monitoring wells and historically observed streamflows at 19 streamgages. Calibration of 81 model parameters was accomplished in a semi-automated manner by using the software PEST. Final estimated parameter values generally were consistent with parameter estimates from previous studies. About 92 percent of simulated groundwater levels were within 20 feet (ft) vertically of observed values, and 89 percent of simulated streamflows were within $500 \mathrm{ft}^{3} / \mathrm{s}$ of observed values, indicating a well-calibrated model. The correlation coefficients of 0.98 for groundwater levels and 0.96 for streamflows indicated a good match between the trends of the simulated and observed values. A sensitivity analysis was performed to test the robustness of the calibrated parameter values.

The model generated monthly water budgets for agricultural water use, groundwater flow, and streamflow from 1962 to 2003. The groundwater flow budget showed the change in aquifer storage varies with hydrologic conditions; the average annual change in storage from 1962 to 2003 was a depletion of 64,000 acre-feet per year (acre-ft/yr). This storage loss occurs mostly in subregions that rely on groundwater pumping to meet demands. As indicated in the farm budget, the model estimated an average agricultural groundwater pumping of 1,110,000 acre-ft/yr. The streamflow budget showed an average annual net stream seepage to groundwater of 367,000 acre-ft/yr (510 cubic-feet per second), which included seepage from the main San Joaquin River channel, the San Joaquin River flood-control bypass system, and the major San Joaquin River tributaries. The median seepage rate was 280,000 acre-ft/yr; the annual stream seepage ranged from 903,000 acre-feet (acre-ft) in 1983 to 166,000 acre-ft in 1985.

Understanding the limitations of the SJRRPGW is important before it is applied to various problems. Future enhancements to SJRRPGW are planned to address some of these limitations, including extending the calibration period to 
the 2013, subdividing the monthly stress periods, utilizing a more robust solver (such as NWT), and embedding the model within the Central Valley Hydrologic Model by using Local Grid Refinement. The predictive uncertainty of simulated stream seepage will also be further investigated by evaluating the sensitivity of seepage rates to estimated parameter values and alternate sediment-texture distributions.

\section{References Cited}

Anderman, E.R., and Hill, M.C., 2000, MODFLOW-2000, the U.S. Geological Survey modular ground-water modelDocumentation of the Hydrogeologic-Unit Flow (HUF) Package: U.S. Geological Survey Open-File Report 00-342, 89 p., http://pubs.usgs.gov/of/2000/0342/report.pdf.

Anderman, E.R., and Hill, M.C., 2003, MODFLOW-2000, the U.S. Geological Survey modular ground-water modelThree additions to the Hydrogeologic-Unit Flow (HUF) Package-Alternative storage for the uppermost active cells, flows in hydrogeologic units, and the hydraulicconductivity depth-dependence (KDEP) capability: U.S. Geological Survey Open-File Report 2003-347, 36 p., http://pubs.usgs.gov/of/2003/0347/report.pdf.

Bartow, J.A., 1991, The Cenozoic evolution of the San Joaquin Valley, California: U.S. Geological Survey Professional Paper 1501, 40 p, 2 pls., http://pubs.usgs.gov/ pp/1501/report.pdf.

Belitz, K.R., and Heimes, F.J., 1990, Character and evolution of the ground-water flow system in the central part of the western San Joaquin Valley, California: U.S. Geological Survey Water-Supply Paper 2348, 28 p., http://pubs.usgs. gov/wsp/2348/report.pdf.

Belitz, K., and Phillips, S.P., 1995, Alternative to agricultural drains in California's San Joaquin Valley-Results of a regional-scale hydrogeologic approach: Water Resources Research, v. 31, no. 8, p. 1845-1862, http://onlinelibrary. wiley.com/doi/10.1029/95WR01328/pdf.

Bertoldi, G.L., Johnston, R.H., and Evenson, K.D., 1991, Ground water in the Central Valley, California-A summary report: U.S. Geological Survey Professional Paper 1401-A, 44 p., http://pubs.usgs.gov/pp/1401a/report.pdf.

Burow, K.R., Jurgens, B.C., Kauffman, L.J., Phillips, S.P., Dalgish, B.A., and Shelton, J.L., 2008, Simulations of ground-water flow and particle pathline analysis in the zone of contribution of a public-supply well in Modesto, eastern San Joaquin Valley, California: U.S. Geological Survey Scientific Investigations Report 2008-5035, 41 p., http://pubs. usgs.gov/sir/2008/5035.
Burow, K.R., Shelton, J.L., Hevesi, J.A., and Weissmann, G.S., 2004, Hydrogeologic characterization of the Modesto area, San Joaquin Valley California: U.S. Geological Survey Scientific Investigations Report 2004-5232, 62 p., http:// pubs.water.usgs.gov/sir20045232.

California Department of Water Resources, 2011a, Water Resource Integrated Modeling System 2 (WRIMS 2): Sacramento, Calif, Department of Water Resources, accessed June 1, 2011, at http://baydeltaoffice.water.ca.gov/modeling/ hydrology/WRIMS2/index.cfm.

California Department of Water Resources, 2011b, California Land \& Water Use, accessed June 1, 2011, at http://www. water.ca.gov/landwateruse/.

California State University Chico, 2003, The Central Valley Historical Vegetation Mapping Project: California State University, Chico, Department of Geography and Planning and Geographic Information Center, $25 \mathrm{p}$.

Carle, S.F., 1999, TPROGS - Transition probability geostatistical software, version 2.1, user manual: Davis, Calif., Hydrologic Sciences Graduate Group, University of California.

Carle, S.F., and Fogg, G.E., 1996, Transition probability-based indicator geostatistics: Mathematical Geology, v. 28, no. 4, p. 453-476, http://dx.doi.org/10.1007/BF02083656.

Carle, S.F., and Fogg, G.E., 1997, Modeling spatial variability with one and multidimensional continuous-lag Markov chains: Mathematical Geology, v. 29, no. 7, p. 891-918, http://dx.doi.org/ 10.1023/A:1022303706942.

Climate Source, 2006, Parameter-Elevation Regressions on Independent Slopes Model (PRISM) Data, accessed June 1, 2011, at $h t t p: / / w w w . p r i s m . o r e g o n s t a t e . e d u /$.

Croft, M.G., 1972, Subsurface geology of the late Tertiary and Quaternary water-bearing deposits of the southern part of the San Joaquin Valley, California: U.S. Geological Survey Water-Supply Paper 1999-H, 29 p., http://pubs.usgs.gov/ wsp/1999h/report.pdf.

Doherty, John, 2005, PEST model-independent parameter estimation user manual, 5th edition: Watermark Numerical Computing, variously paged, accessed June 1, 2011, at http://www.pesthomepage.org/Downloads.php.

Deverel, S.J., 2005, Expert report of Dr. Steven J. Deverel, PH.D-Qualifications and experience: E.D. Cal. No. Civ. 88-1658 LKK.

Faunt, C.C., ed., 2009, Groundwater availability of the Central Valley aquifer, California: U.S. Geological Survey Professional Paper 1766, 225 p., http://pubs.usgs.gov/pp/1766/. 
Fleckenstein, J.H., Niswonger, R.G., and Fogg, G.E., 2006, River-aquifer interactions, geologic heterogeneity, and lowflow management: Ground Water, v. 44, no. 6, p. 837-852, http://dx.doi.org/10.1111/j.1745-6584.2006.00190.x.

Fogg, G.E., Noyes, C.D., and Carle, S.F., 1998, Geologically based model of heterogeneous hydraulic conductivity in an alluvial setting: Hydrogeology Journal, v. 6, no. 1, p. 131-143, http://dx.doi.org/10.1007/s100400050139.

Gesch, Dean, Evans, Gayla, Mauck, James, Hutchinson, John, and Carswell, W.J., Jr., 2009, The National Map-Elevation: U.S. Geological Survey Fact Sheet 2009-3053, 4 p., http://pubs.usgs.gov/fs/2009/3053/pdf/fs2009_3053.pdf.

Hanson, R.T., and Leake, S.A., 1999, Documentation for HYDMOD: a program for extracting and processing time-series data from the U.S. Geological Survey's modular three-dimensional finite-difference ground-water flow model: U.S. Geological Survey Open-File Report 98-564, 57 p., http://pubs.usgs.gov/of/1998/0564/report.pdf.

Harbaugh, A.W., 2005, MODFLOW-2005, the U.S. Geological Survey modular ground-water model-The groundwater flow process: U.S. Geological Survey Techniques and Methods book 6, chap. A16, variously paged, http://pubs. er.usgs.gov/publication/tm6A16.

Hargreaves, G.H., and Samani, Z.A., 1982, Estimating potential evapotranspiration: Journal of the Irrigation and Drainage Division, v. 108, no. 3, p. 225-230.

Hill, M.C., and Tiedeman, C.R., 2007, Effective groundwater model calibration-With analysis of data, sensitivities, predictions, and uncertainty: Hoboken, N.J., John Wiley and Sons, Inc., $480 \mathrm{p}$.

Hill, M.C., Banta, E.R., Harbaugh, A.W., and Anderman, E.R., 2000, MODFLOW-2000, the U.S. Geological Survey modular ground-water model; user guide to the observation, sensitivity, and parameter-estimation processes and three post-processing programs: U.S. Geological Survey Open-File Report 2000-184, 209 p., http://pubs.usgs.gov/ of/2000/0184/report.pdf.

Isaaks, E.H., and Srivastava, R.M., 1989, An introduction to applied geostatistics: New York, N.Y., Oxford University Press, $592 \mathrm{p}$.

Kings River Water Association, (1961-2003). Annual Watermaster Reports from 1961 through 2003, Kings River Water Association. Fresno, Calif., variously paged.

Lee, Si-Yong, Carle, S.F., and Fogg, G.E., 2007, Geologic heterogeneity and a comparison of two geostatistical models-Sequential Gaussian and transition probability-based geostatistical simulation: Advances in Water Resources, v. 30, no. 9, p. 1914-1932, http://dx.doi.org/10.1016/j. advwatres.2007.03.005.
Marchand, D.E., and Allwardt, Alan, 1981, Late Cenozoic stratigraphic units, northeastern San Joaquin Valley, California: U.S. Geological Survey Bulletin 1470, 70 p., http:// pubs.usgs.gov/bul/1470/report.pdf.

McBain and Trush, Inc., ed., 2002, San Joaquin River restoration study background report: Arcata, Calif., prepared for Friant Water Users Authority, Lindsay, Calif., and Natural Resources Defense Council, San Francisco, Calif., variously paged, http://www.waterboards.ca.gov/waterrights/ water_issues/programs/bay_delta/bay_delta_plan/ water_quality_control_planning/docs/sjrf_spprtinfol mcbainandtrush_2002.pdf.

Mehl, S.W., and Hill, M.C., 2005, MODFLOW-2005, the U.S. Geological Survey modular ground-water model-Documentation of shared node local grid refinement (LGR) and the boundary flow and head (BFH) package: U.S. Geological Survey Techniques and Methods, book 6, chap. A12, 68 p., http://pubs.water.usgs.gov/tm6a12.

National Historical Geographic Information System, 2011, National historical geographic information system: Twin Cities, Minn., University of Minnesota database, https:// www.nhgis.org/.

Natural Resources Defense Council versus Kirk Rodgers, Stipulation of Settlement, 2006, CIV S-88-1658 LKK/GGH (United States District Court Easter District of California, September 13, 2006), http://www.restoresjr.net/program_ library/06-Settlement_Related/index.html.

Niswonger, R.G., Panday, Sorab, and Ibaraki, Motomu, 2011, MODFLOW-NWT, A Newton formulation for MODFLOW-2005: U.S. Geological Survey Techniques and Methods, book 6, chap. A37, 44 p., http://pubs.usgs.gov/tm/ tm6a37/pdf/tm6a37.pdf.

Niswonger, R.G., and Prudic, D.E., 2005, Documentation of the Streamflow-Routing (SFR2) Package to include unsaturated flow beneath streams-A modification to SFR1: U.S. Geological Survey Techniques and Methods, book 6, chap. A13, 50 p., http://pubs.usgs.gov/tm/2006/tm6A13/pdf/ tm6a13.pdf.

Page, R.W., 1986, Geology of the fresh ground-water basin of the Central Valley, California, with texture maps and sections: U.S. Geological Survey Professional Paper 1401-C, 54 p., 5 pls., http://pubs.er.usgs.gov/publication/pp1401C.

Phillips, S.P., Green, C.T., Burow, K.R., Shelton, J.L., and Rewis, D.L., 2007, Simulation of multiscale ground-water flow in part of the northeastern San Joaquin Valley, California: U.S. Geological Survey Scientific-Investigations Report 2007-5009, 43 p., http://pubs.water.usgs.gov/sir20075009. 
Ritzi, R.W., Jr., Dominic, D.F., Brown, N.R., Kausch, K.W., McAlenney, P.J., and Basial, M.J., 1995, Hydrofacies distribution and correlation in the Miami Valley aquifer system: Water Resources Research, v. 31, no. 12, p. 3271-3281, http://dx.doi.org/10.1029/95WR02564.

Ritzi, R.W., Jr., Dominic, D.F., Slesers, A.J., Greer, C.B., Reboulet, E.C., Telford, J.A., Masters, R.W., Klohe, C.A., Bogle, J.L., and Means, B.P., 2000, Comparing statistical models of physical heterogeneity in buried-valley aquifers: Water Resources Research, v. 36, no. 11, p. 3179-3192, http://dx.doi.org/10.1029/2000WR900143.

Schmid, Wolfgang, and Hanson, R.T., 2009, The Farm Process Version 2 (FMP2) for MODFLOW-2005-Modifications and upgrades to FMP1: U.S. Geological Survey Techniques and Methods, book 6, chap. A32, 102 p., http://pubs.usgs. gov/tm/tm6a32/pdf/tm6a32.pdf.

San Joaquin River Restoration Program, 2012, San Joaquin River Restoration Program-Background and History, accessed June 1, 2011, at http://www.restoresjr.net/ background.html.

Tetra Tech, 2010, Draft San Joaquin River Interim Flow Unsteady Modeling Analysis. California. Sacramento, California: U.S. Bureau of Reclamation, Mid-Pacific Region, 35 p, http://www.usbr.gov/mp/nepa/documentShow. cfm?Doc_ID $=5861$.

U.S. Bureau of Reclamation, 1962, Definite plan report, San Luis Unit, Central Valley Project, California. Sacramento, California: U.S. Bureau of Reclamation, Mid-Pacific Region, $331 \mathrm{p}$.

U.S. Bureau of Reclamation, Central Valley Operations Office, 2011, Report of Operations Monthly Delivery Tables: Sacramento, Calif., accessed June 1, 2011, at http://www.usbr. gov/mp/cvo/deliv.html.

U.S. Department of Agriculture, Natural Resource Conservation Service, 2005, State Soil Geographic Database (STATSGO), accessed June 1, 2011, at http://datagateway. nrcs.usda.gov/.

U.S. Geologic Survey, 1990, Land use and land cover digital data 1:250,000- and 1:100,000-scale maps_-Data users guide 4: U.S. Geological Survey, accessed June 1, 2011, at http://vterrain.org/Culture/LULC/Data_Users_Guide_4. html.

U.S. Geologic Survey, 1999, National land cover dataset 1992 (NLCD 1992): U.S. Geological Survey database, accessed June 1, 2011, at http://landcover.usgs.gov/natllandcover. php.

U.S. Geologic Survey, 2011, Hydrography-National hydrography dataset: U.S. Geological Survey database, accessed June 1, 2011, at http://nhd.usgs.gov/index.html.
Weissmann, G.S., Bennett, G.L., and Lansdale, A.L., 2005, Factors controlling sequence development on Quaternary fluvial fans, San Joaquin Basin, California, USA: Geological Society, London, Special Publications, v. 251, p. 169-186, http://dx.doi.org/10.1144/GSL. SP.2005.251.01.12.

Weissmann, G.S., Carle, S.F., and Fogg, G.E., 1999, Threedimensional hydrofacies modeling based on soil surveys and transition probability geostatistics: Water Resources Research, v. 35, no., 6, p. 1761-1770, http://dx.doi. org/10.1029/1999WR900048.

Weissmann, G.S., and Fogg, G.E., 1999, Multi-scale alluvial fan heterogeneity modeled with transition probability geostatistics in a sequence stratigraphic framework: Journal of Hydrology, v. 226, no. 1-2, p. 48-65, http://dx.doi. org/10.1016/S0022-1694(99)00160-2. 


\section{Appendix A. Crop-Related Data Utilized from the Central Valley Hydrologic Model (CVHM)}

This appendix provides values for crop-related datasets utilized in the San Joaquin River Restoration Program Groundwater flow model (SJRRPGW) by the Farm Process (FMP2) (table A-1, A-2, A-3, fig. A-1). 


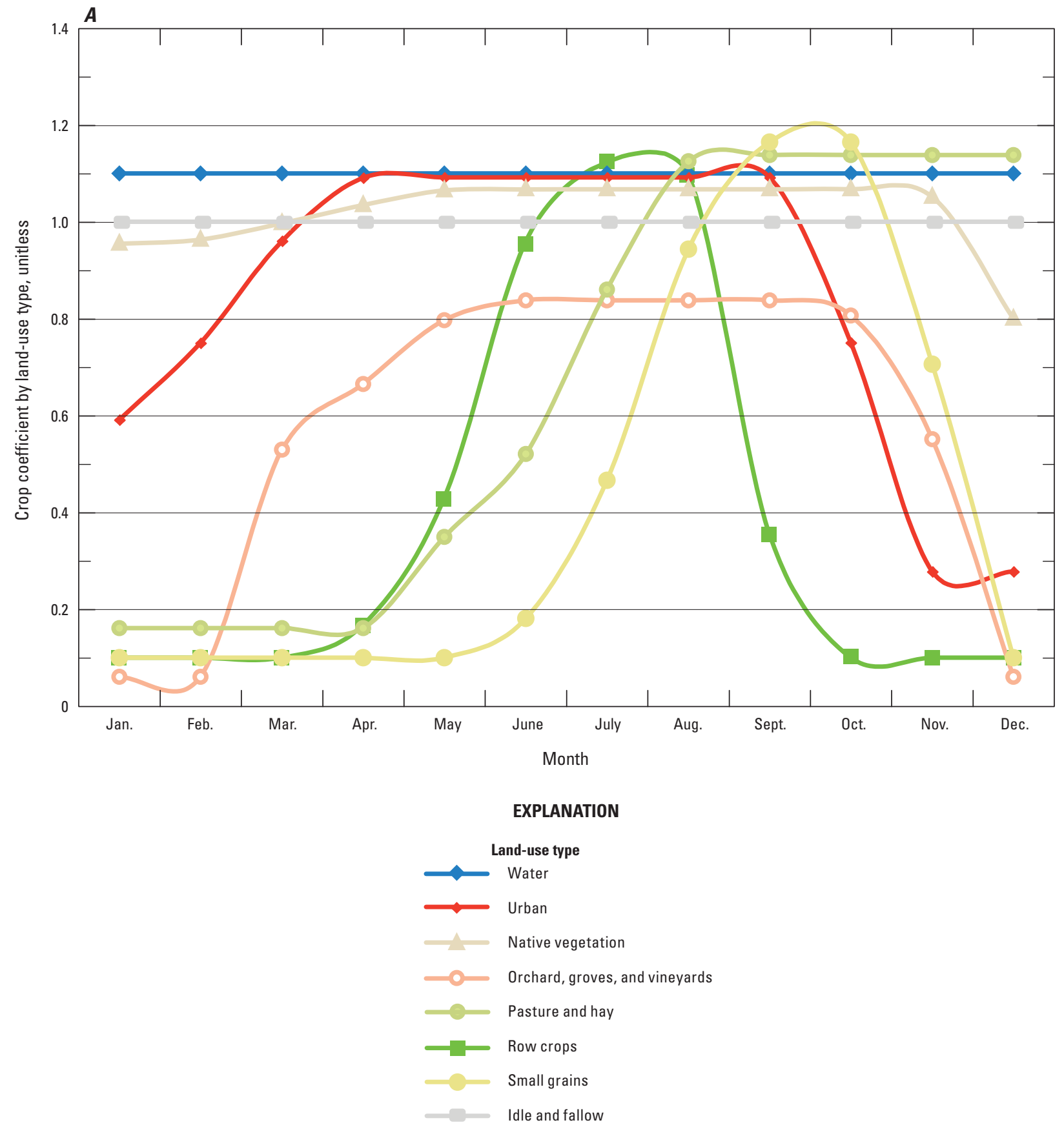

Figure A-1. Monthly crop coefficients for each crop utilized in the San Joaquin River Restoration Program groundwater flow model (SJRRPGW) by different land-use types: A, agricultural, undeveloped, and other uses; B, agricultural uses; C, agricultural and other developed uses. 


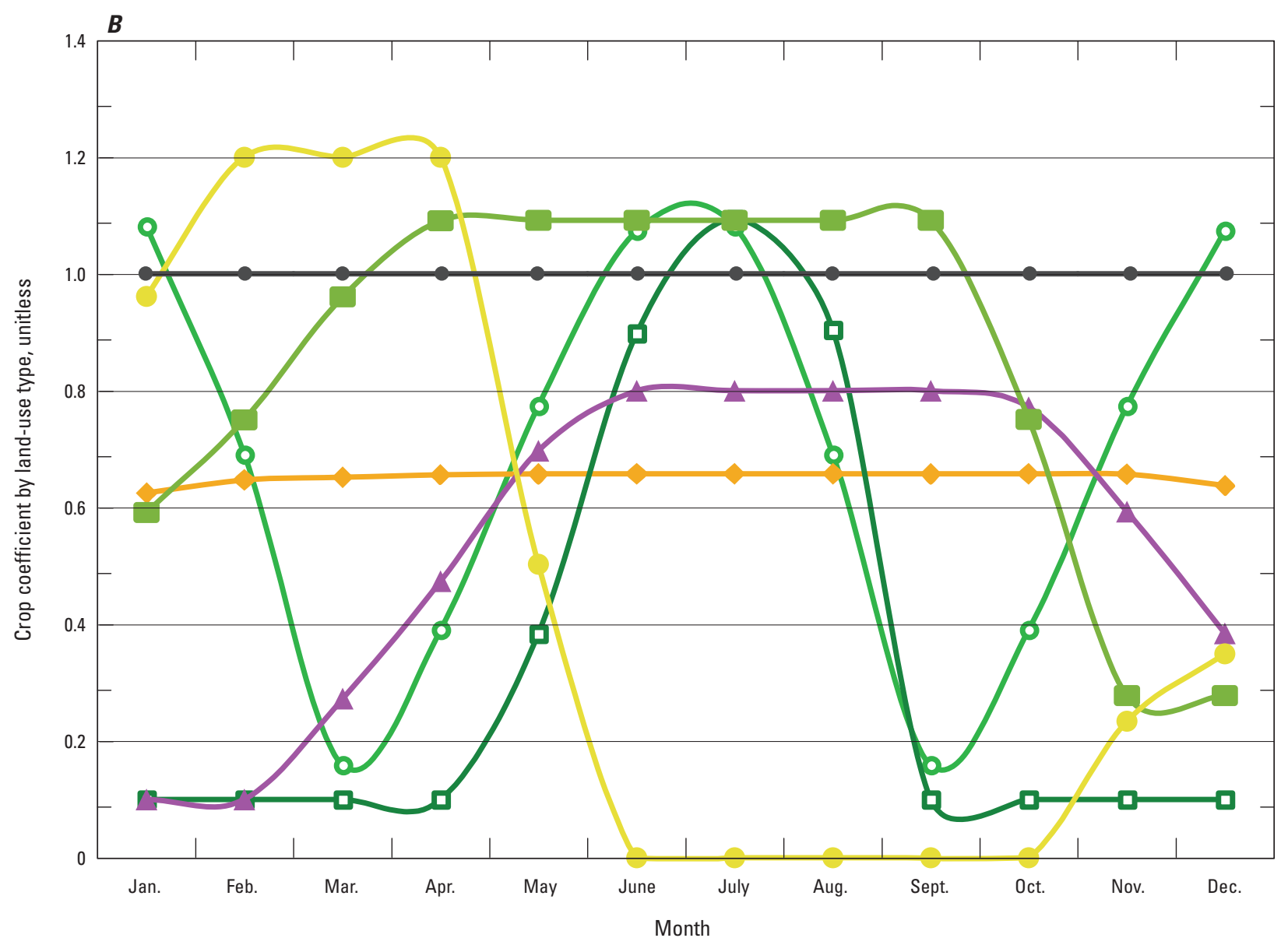

EXPLANATION

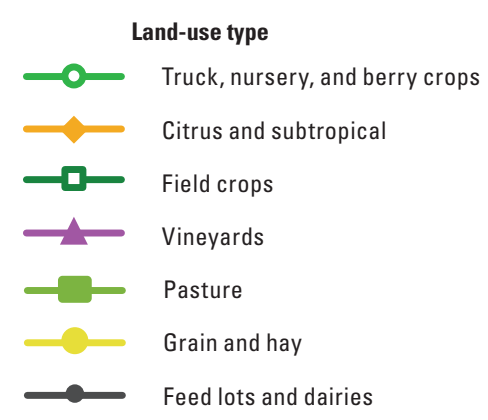

Figure A-1. - Continued 


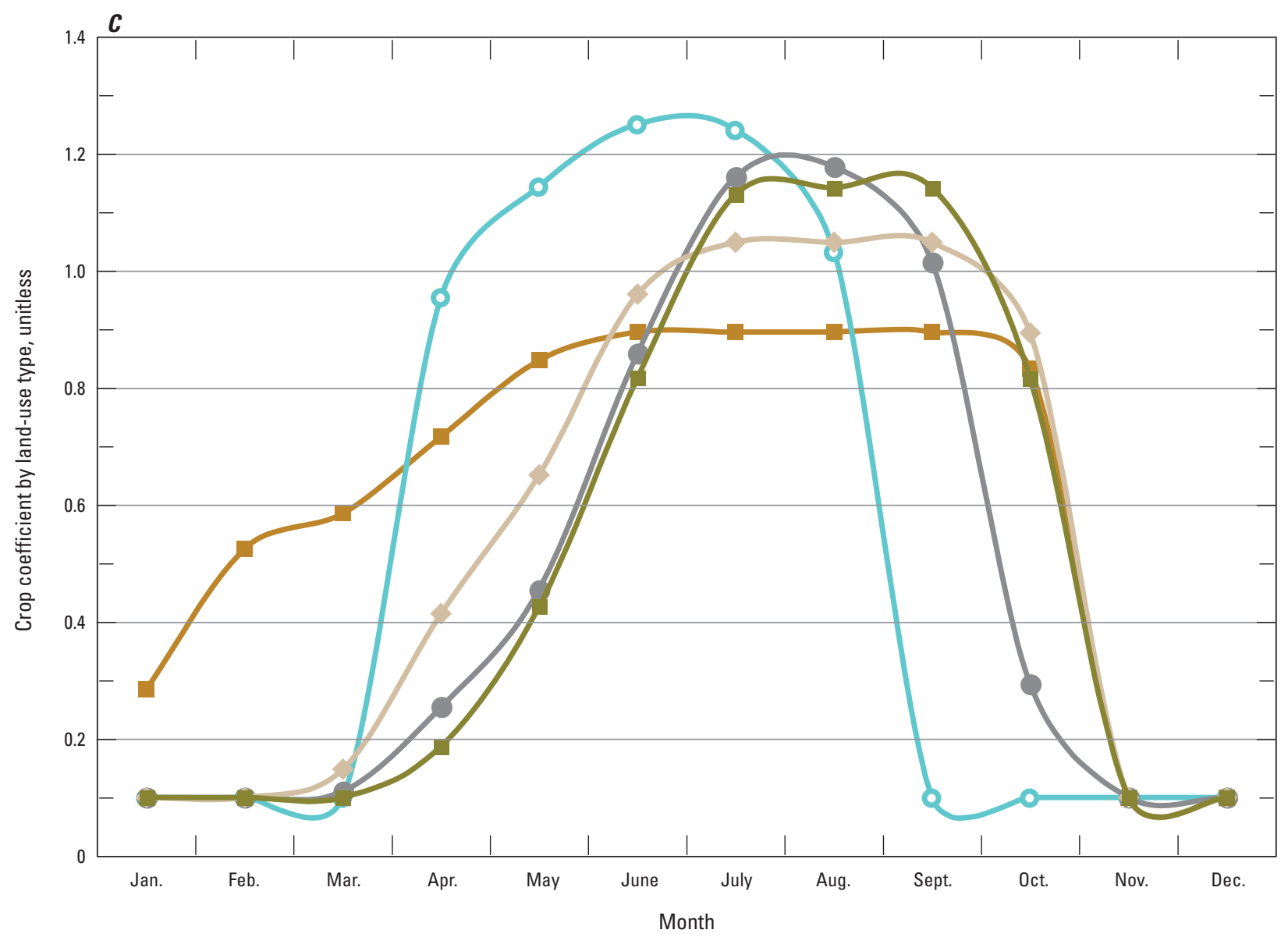

EXPLANATION

Land-use type

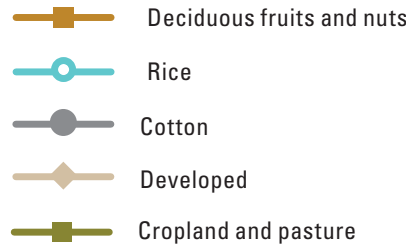

Figure A-1. - Continued 
Table A-1. Non-time varying crop-related data in study area for each crop type.

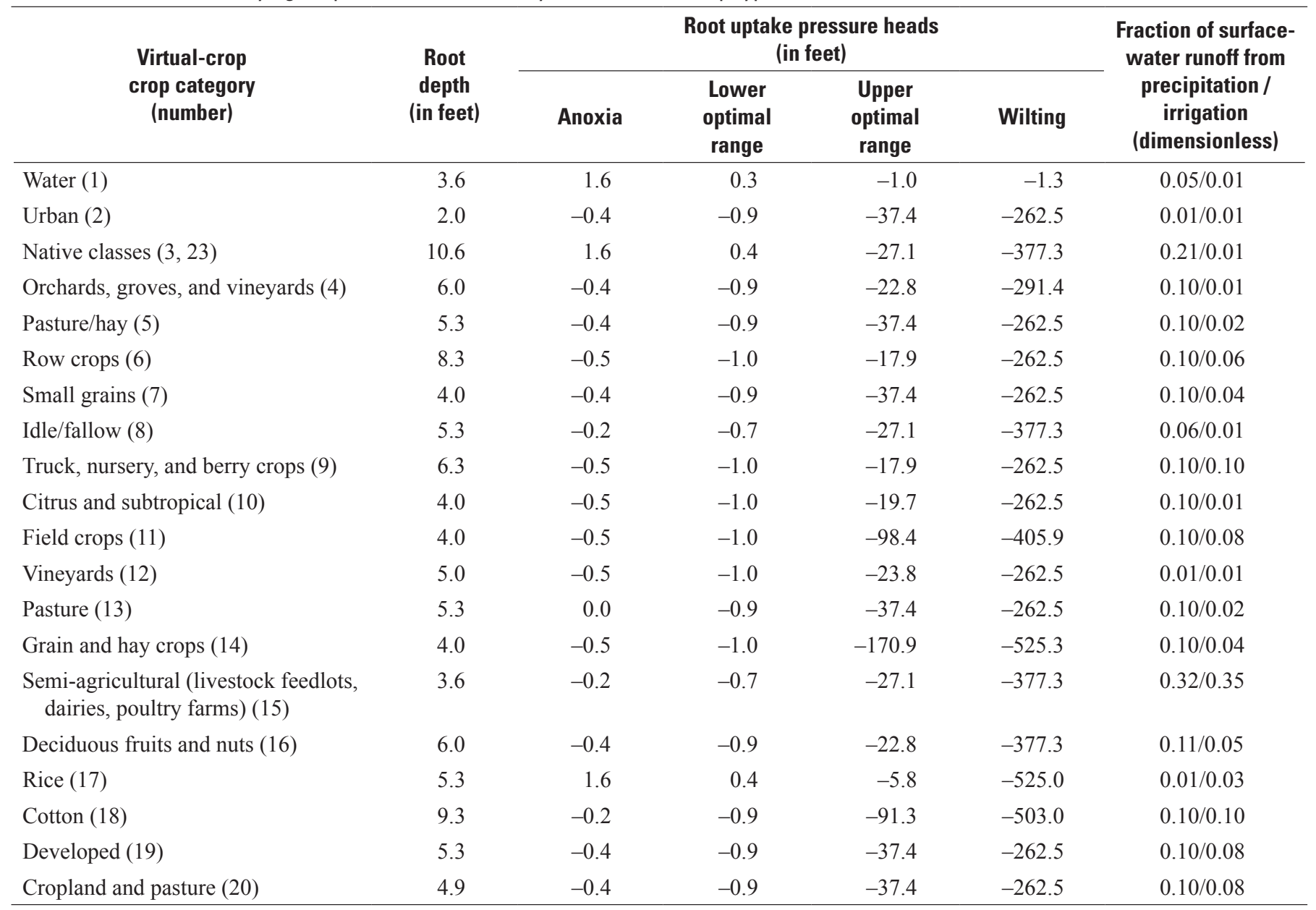


Table A-2. Fractions of transportation and evaporation of consumptive use for each crop type.

[Abbreviations: Fei, Evaporative fraction of consumptive use related to irrigation; Fep, Evaporative fraction of consumptive use related to precipitation; Ftr, Transpiratory fraction of consumptive use]

\begin{tabular}{|c|c|c|c|c|c|c|}
\hline $\begin{array}{l}\text { Virtual-crop crop category } \\
\text { (number) }\end{array}$ & $\begin{array}{c}\text { January } \\
\text { (Ftr/Fep/Fei) }\end{array}$ & $\begin{array}{c}\text { February } \\
\text { (Ftr/Fep/Fei) }\end{array}$ & $\begin{array}{c}\text { March } \\
\text { (Ftr/Fep/Fei) }\end{array}$ & $\begin{array}{c}\text { April } \\
\text { (Ftr/Fep/Fei) }\end{array}$ & $\begin{array}{c}\text { May } \\
\text { (Ftr/Fep/Fei) }\end{array}$ & $\begin{array}{c}\text { June } \\
\text { (Ftr/Fep/Fei) }\end{array}$ \\
\hline Water (1) & $0.00 / 1.00 / 1.00$ & $0.00 / 1.00 / 1.00$ & $0.00 / 1.00 / 1.00$ & $0.00 / 1.00 / 1.00$ & $0.00 / 1.00 / 1.00$ & $0.00 / 1.00 / 1.00$ \\
\hline Urban (2) & $0.25 / 0.75 / 0.02$ & $0.25 / 0.75 / 0.02$ & $0.25 / 0.75 / 0.02$ & $0.25 / 0.75 / 0.02$ & $0.25 / 0.75 / 0.02$ & $0.25 / 0.75 / 0.02$ \\
\hline Native classes (3 and 23) & $0.28 / 0.72 / 0.72$ & $0.28 / 0.72 / 0.72$ & $0.66 / 0.34 / 0.34$ & $0.66 / 0.34 / 0.34$ & $0.66 / 0.34 / 0.34$ & $0.66 / 0.34 / 0.34$ \\
\hline Orchards, groves, and vineyards (4) & $0.20 / 0.80 / 0.80$ & $0.20 / 0.80 / 0.80$ & $0.37 / 0.63 / 0.63$ & $0.23 / 0.77 / 0.77$ & $0.46 / 0.54 / 0.54$ & $0.47 / 0.53 / 0.53$ \\
\hline Pasture/hay (5) & $0.50 / 0.50 / 0.50$ & $0.50 / 0.50 / 0.50$ & $0.50 / 0.50 / 0.50$ & $0.50 / 0.50 / 0.50$ & $0.72 / 0.28 / 0.28$ & $0.88 / 0.12 / 0.12$ \\
\hline Row crops (6) & $0.11 / 0.89 / 0.89$ & $0.11 / 0.89 / 0.89$ & $0.11 / 0.89 / 0.89$ & $0.09 / 0.91 / 0.91$ & $0.36 / 0.64 / 0.64$ & $0.46 / 0.54 / 0.54$ \\
\hline Small grains (7) & $0.00 / 1.00 / 1.00$ & $0.00 / 1.00 / 1.00$ & $0.00 / 1.00 / 1.00$ & $0.00 / 1.00 / 1.00$ & $0.00 / 1.00 / 1.00$ & $0.00 / 1.00 / 1.00$ \\
\hline Idle/fallow (8) & $0.00 / 1.00 / 0.00$ & $0.00 / 1.00 / 0.00$ & $0.00 / 1.00 / 0.00$ & $0.00 / 1.00 / 0.00$ & $0.00 / 1.00 / 0.00$ & $0.00 / 1.00 / 0.00$ \\
\hline Truck, nursery, and berry crops (9) & $0.80 / 0.20 / 0.18$ & $0.80 / 0.20 / 0.18$ & $0.39 / 0.61 / 0.61$ & $0.44 / 0.56 / 0.36$ & $0.42 / 0.58 / 0.38$ & $0.80 / 0.20 / 0.18$ \\
\hline Citrus and subtropical (10) & $0.27 / 0.73 / 0.73$ & $0.27 / 0.73 / 0.73$ & $0.46 / 0.54 / 0.14$ & $0.46 / 0.54 / 0.14$ & $0.46 / 0.54 / 0.14$ & $0.46 / 0.54 / 0.14$ \\
\hline Field crops (11) & $0.01 / 0.99 / 0.99$ & $0.01 / 0.99 / 0.99$ & $0.01 / 0.99 / 0.99$ & $0.15 / 0.85 / 0.85$ & $0.15 / 0.85 / 0.85$ & $0.94 / 0.06 / 0.06$ \\
\hline Vineyards (12) & $0.00 / 1.00 / 0.03$ & $0.00 / 1.00 / 0.03$ & $0.28 / 0.72 / 0.22$ & $0.40 / 0.60 / 0.10$ & $0.38 / 0.62 / 0.12$ & $0.36 / 0.64 / 0.14$ \\
\hline Pasture (13) & $0.18 / 0.82 / 0.82$ & $0.15 / 0.85 / 0.85$ & $0.46 / 0.64 / 0.64$ & $0.91 / 0.09 / 0.03$ & $0.91 / 0.09 / 0.03$ & $0.91 / 0.09 / 0.03$ \\
\hline Grain and hay crops (14) & $0.46 / 0.54 / 0.54$ & $0.92 / 0.08 / 0.08$ & $0.92 / 0.08 / 0.08$ & $0.92 / 0.08 / 0.08$ & $0.23 / 0.77 / 0.77$ & $0.00 / 1.00 / 1.00$ \\
\hline Semi-agricultural (15) & $0.00 / 1.00 / 1.00$ & $0.00 / 1.00 / 1.00$ & $0.00 / 1.00 / 1.00$ & $0.00 / 1.00 / 1.00$ & $0.00 / 1.00 / 1.00$ & $0.00 / 1.00 / 1.00$ \\
\hline Deciduous fruits and nuts (16) & $0.10 / 0.90 / 0.90$ & $0.10 / 0.90 / 0.90$ & $0.10 / 0.90 / 0.90$ & $0.50 / 0.50 / 0.50$ & $0.50 / 0.50 / 0.50$ & $0.97 / 0.03 / 0.03$ \\
\hline Rice (17) & $0.20 / 0.80 / 0.50$ & $0.20 / 0.80 / 0.50$ & $0.20 / 0.80 / 0.50$ & $0.75 / 0.25 / 0.25$ & $0.75 / 0.25 / 0.25$ & $0.80 / 0.20 / 0.10$ \\
\hline Cotton (18) & $0.75 / 0.25 / 0.25$ & $0.75 / 0.25 / 0.25$ & $0.75 / 0.25 / 0.25$ & $0.43 / 0.57 / 0.17$ & $0.75 / 0.25 / 0.20$ & $0.75 / 0.25 / 0.20$ \\
\hline Developed (19) & $0.30 / 0.70 / 0.67$ & $0.30 / 0.70 / 0.67$ & $0.22 / 0.78 / 0.78$ & $0.16 / 0.84 / 0.84$ & $0.42 / 0.58 / 0.38$ & $0.85 / 0.15 / 0.15$ \\
\hline Cropland and pasture (20) & $0.00 / 1.00 / 1.00$ & $0.00 / 1.00 / 1.00$ & $0.00 / 1.00 / 1.00$ & $0.00 / 1.00 / 1.00$ & $0.20 / 0.80 / 0.80$ & $0.30 / 0.70 / 0.70$ \\
\hline $\begin{array}{l}\text { Virtual-crop crop category } \\
\text { (number) }\end{array}$ & $\begin{array}{c}\text { July } \\
\text { (Ftr/Fep/Fei) }\end{array}$ & $\begin{array}{c}\text { August } \\
\text { (Ftr/Fep/Fei) }\end{array}$ & $\begin{array}{l}\text { September } \\
\text { (Ftr/Fep/Fei) }\end{array}$ & $\begin{array}{c}\text { October } \\
\text { (Ftr/Fep/Fei) }\end{array}$ & $\begin{array}{l}\text { November } \\
\text { (Ftr/Fep/Fei) }\end{array}$ & $\begin{array}{l}\text { December } \\
\text { (Ftr/Fep/Fei) }\end{array}$ \\
\hline Water (1) & $0.00 / 1.00 / 1.00$ & $0.00 / 1.00 / 1.00$ & $0.00 / 1.00 / 1.00$ & $0.00 / 1.00 / 1.00$ & $0.00 / 1.00 / 1.00$ & $0.00 / 1.00 / 1.00$ \\
\hline Urban (2) & $0.25 / 0.75 / 0.02$ & $0.25 / 0.75 / 0.02$ & $0.25 / 0.75 / 0.02$ & $0.25 / 0.75 / 0.02$ & $0.25 / 0.75 / 0.02$ & $0.25 / 0.75 / 0.02$ \\
\hline Native classes (3) & $0.66 / 0.34 / 0.34$ & $0.66 / 0.34 / 0.34$ & $0.66 / 0.34 / 0.34$ & $0.66 / 0.34 / 0.34$ & $0.66 / 0.34 / 0.34$ & $0.28 / 0.72 / 0.72$ \\
\hline Orchards, groves, and vineyards (4) & $0.47 / 0.53 / 0.53$ & $0.47 / 0.53 / 0.53$ & $0.47 / 0.53 / 0.53$ & $0.47 / 0.53 / 0.53$ & $0.45 / 0.55 / 0.55$ & $0.20 / 0.80 / 0.80$ \\
\hline Pasture/Hay (5) & $0.95 / 0.05 / 0.05$ & $0.96 / 0.04 / 0.04$ & $0.96 / 0.04 / 0.04$ & $0.96 / 0.04 / 0.04$ & $0.96 / 0.04 / 0.04$ & $0.96 / 0.04 / 0.04$ \\
\hline Row Crops (6) & $0.95 / 0.05 / 0.05$ & $0.87 / 0.13 / 0.13$ & $0.12 / 0.88 / 0.88$ & $0.11 / 0.89 / 0.89$ & $0.11 / 0.89 / 0.89$ & $0.11 / 0.89 / 0.89$ \\
\hline Small Grains (7) & $0.20 / 0.80 / 0.80$ & $0.50 / 0.50 / 0.50$ & $0.90 / 0.10 / 0.10$ & $0.90 / 0.10 / 0.10$ & $0.00 / 1.00 / 1.00$ & $0.50 / 0.50 / 0.50$ \\
\hline Idle/fallow (8) & $0.00 / 1.00 / 0.00$ & $0.00 / 1.00 / 0.00$ & $0.00 / 1.00 / 0.00$ & $0.00 / 1.00 / 0.00$ & $0.00 / 1.00 / 0.00$ & $0.00 / 1.00 / 0.00$ \\
\hline Truck, nursery, and berry crops (9) & $0.80 / 0.20 / 0.18$ & $0.80 / 0.20 / 0.18$ & $0.80 / 0.20 / 0.18$ & $0.80 / 0.20 / 0.18$ & $0.80 / 0.20 / 0.18$ & $0.80 / 0.20 / 0.18$ \\
\hline Citrus and subtropical (10) & $0.46 / 0.54 / 0.14$ & $0.46 / 0.54 / 0.14$ & $0.46 / 0.54 / 0.14$ & $0.46 / 0.54 / 0.14$ & $0.46 / 0.54 / 0.14$ & $0.46 / 0.54 / 0.14$ \\
\hline Field crops (11) & $0.94 / 0.06 / 0.06$ & $0.94 / 0.06 / 0.06$ & $0.90 / 0.10 / 0.10$ & $0.01 / 0.99 / 0.99$ & $0.01 / 0.99 / 0.99$ & $0.01 / 0.99 / 0.99$ \\
\hline Vineyards (12) & $0.36 / 0.64 / 0.14$ & $0.36 / 0.64 / 0.14$ & $0.36 / 0.64 / 0.14$ & $0.36 / 0.64 / 0.14$ & $0.36 / 0.64 / 0.14$ & $0.38 / 0.62 / 0.12$ \\
\hline Pasture (13) & $0.96 / 0.04 / 0.04$ & $0.91 / 0.09 / 0.03$ & $0.91 / 0.09 / 0.03$ & $0.46 / 0.64 / 0.64$ & $0.15 / 0.85 / 0.85$ & $0.15 / 0.85 / 0.85$ \\
\hline Grain and hay crops (14) & $0.00 / 1.00 / 1.00$ & $0.00 / 1.00 / 1.00$ & $0.00 / 1.00 / 1.00$ & $0.00 / 1.00 / 1.00$ & $0.16 / 0.84 / 0.84$ & $0.35 / 0.65 / 0.65$ \\
\hline Semi-agricultural (15) & $0.00 / 1.00 / 1.00$ & $0.00 / 1.00 / 1.00$ & $0.00 / 1.00 / 1.00$ & $0.00 / 1.00 / 1.00$ & $0.00 / 1.00 / 1.00$ & $0.00 / 1.00 / 1.00$ \\
\hline Deciduous fruits and nuts (16) & $0.97 / 0.03 / 0.03$ & $0.97 / 0.03 / 0.03$ & $0.97 / 0.03 / 0.03$ & $0.10 / 0.90 / 0.90$ & $0.10 / 0.90 / 0.90$ & $0.10 / 0.90 / 0.90$ \\
\hline Rice (17) & $0.75 / 0.25 / 0.25$ & $0.60 / 0.40 / 0.27$ & $0.20 / 0.80 / 0.50$ & $0.20 / 0.80 / 0.50$ & $0.20 / 0.80 / 0.50$ & $0.20 / 0.80 / 0.50$ \\
\hline Cotton (18) & $0.75 / 0.25 / 0.20$ & $0.75 / 0.25 / 0.20$ & $0.47 / 0.53 / 0.33$ & $0.36 / 0.64 / 0.44$ & $0.75 / 0.25 / 0.25$ & $0.75 / 0.25 / 0.25$ \\
\hline Developed (19) & $0.90 / 0.10 / 0.10$ & $0.90 / 0.10 / 0.10$ & $0.90 / 0.10 / 0.10$ & $0.50 / 0.50 / 0.50$ & $0.30 / 0.70 / 0.70$ & $0.30 / 0.70 / 0.67$ \\
\hline Cropland and pasture (20) & $0.85 / 0.15 / 0.15$ & $0.95 / 0.05 / 0.05$ & $0.90 / 0.10 / 0.10$ & $0.50 / 0.50 / 0.50$ & $0.00 / 1.00 / 1.00$ & $0.00 / 1.00 / 1.00$ \\
\hline
\end{tabular}


Table A-3. Irrigation efficiencies through the simulation period averaged by San Joaquin River Restoration Program groundwater flow model (SJRRPGW) subregion, San Joaquin Valley, California

[Efficiency values are percentages.]

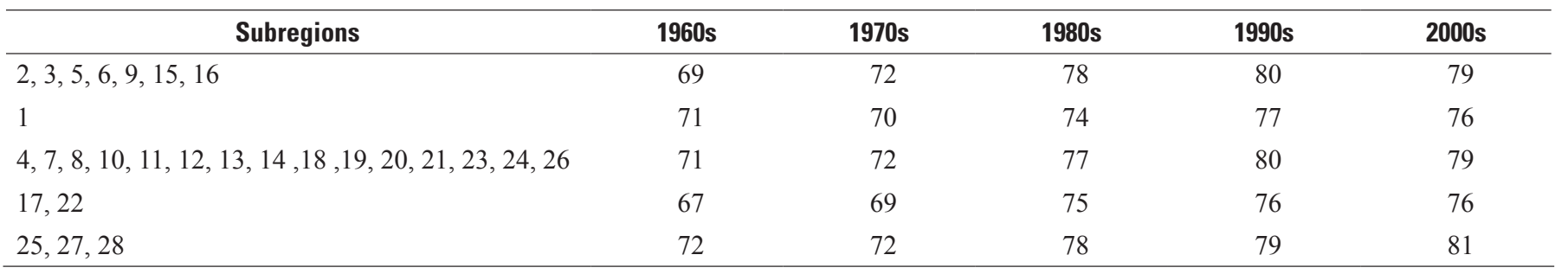


This page intentionally left blank. 


\section{Appendix B. Information for San Joaquin River Restoration Program Groundwater Model Calibration Wells}

This appendix provides well construction and other information for the 133 wells used for the calibration of the San Joaquin River Restoration Program groundwater flow model (SJRRPGW). Fifty-five wells are from the Central California Irrigation District (CCID) monitoring program (table B-1) and seventy eight wells are from California Department of Water Resources (DWR) or U.S. Geological Survey (USGS) databases (table B-2). 


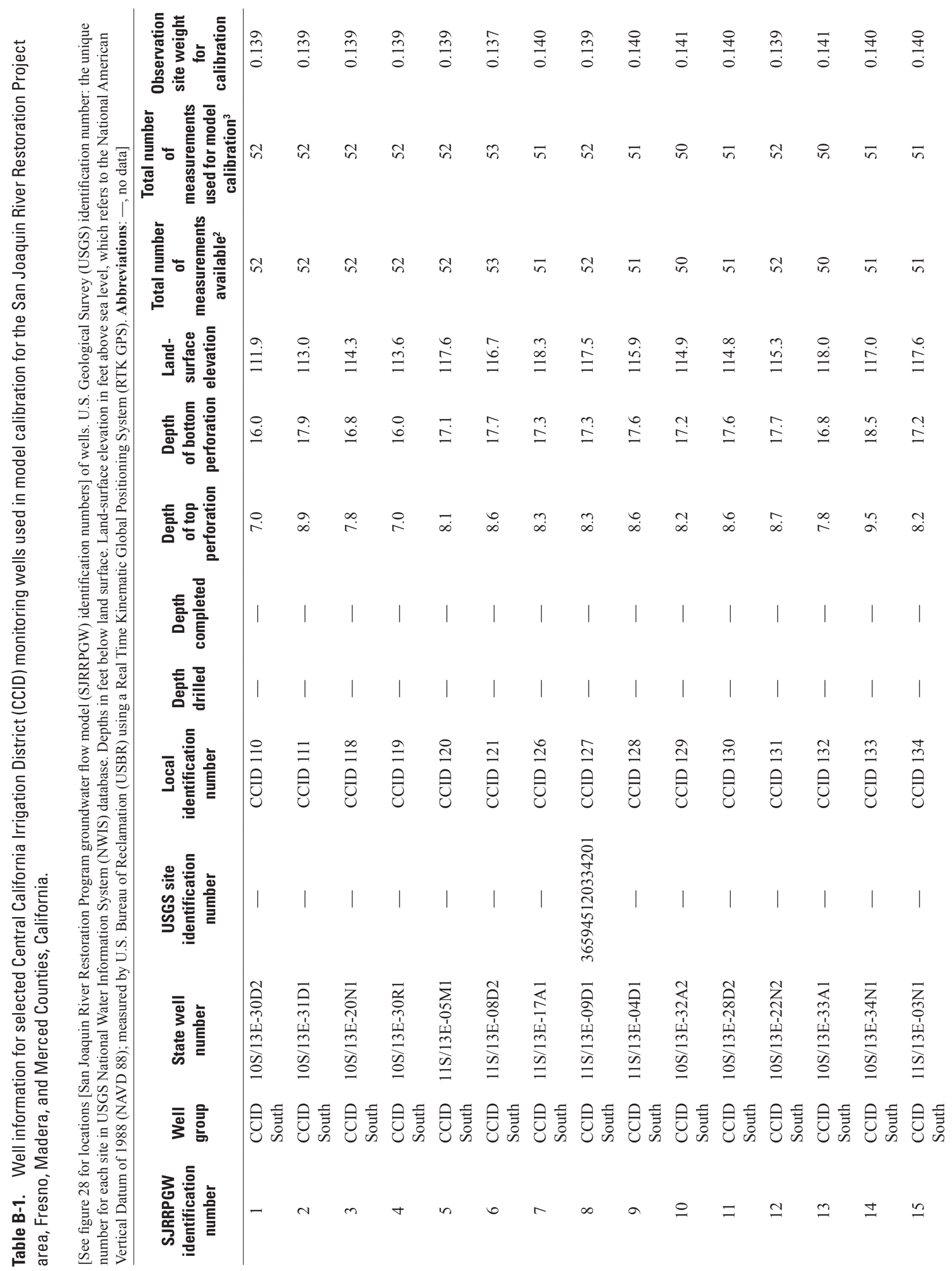




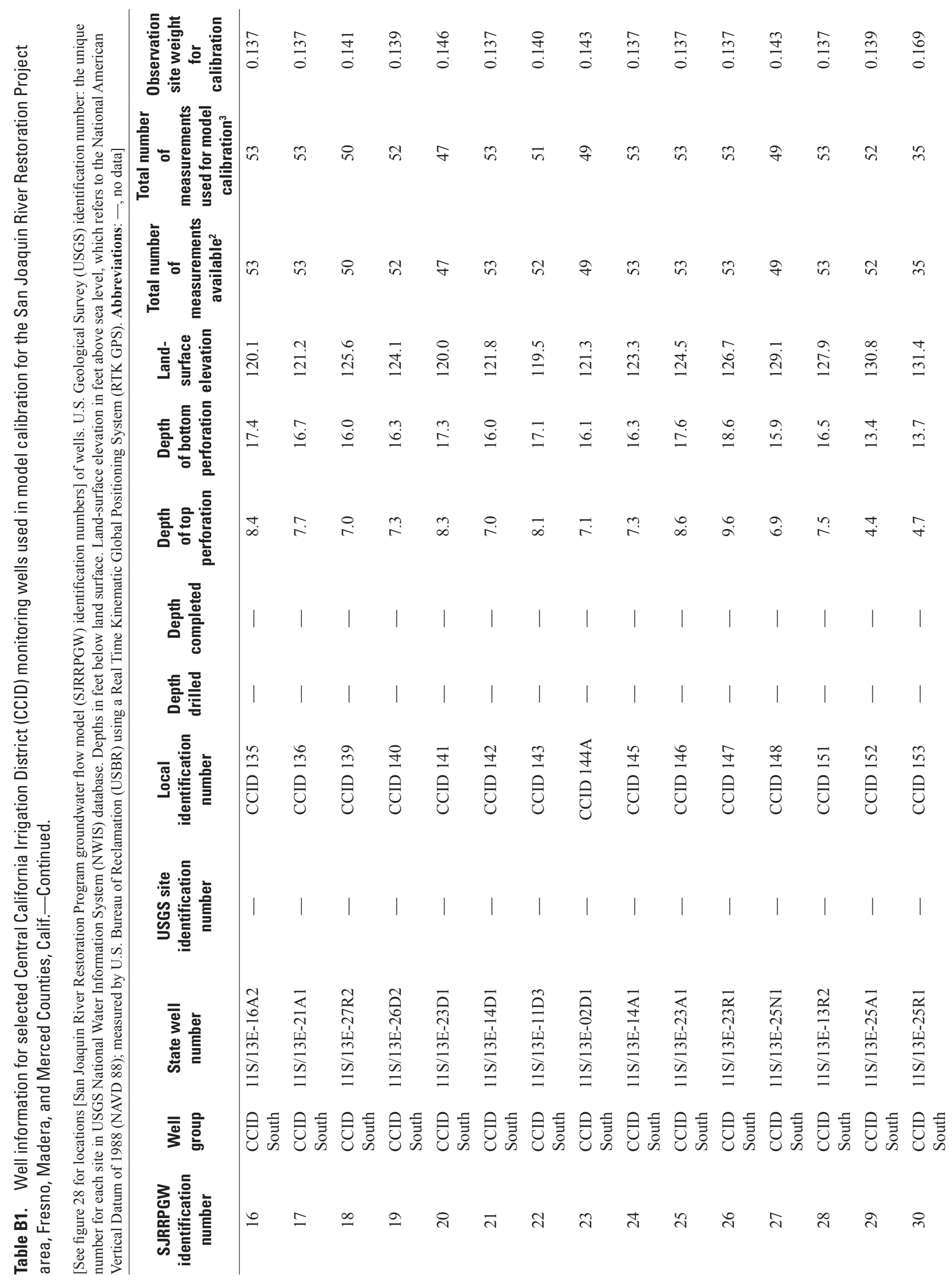




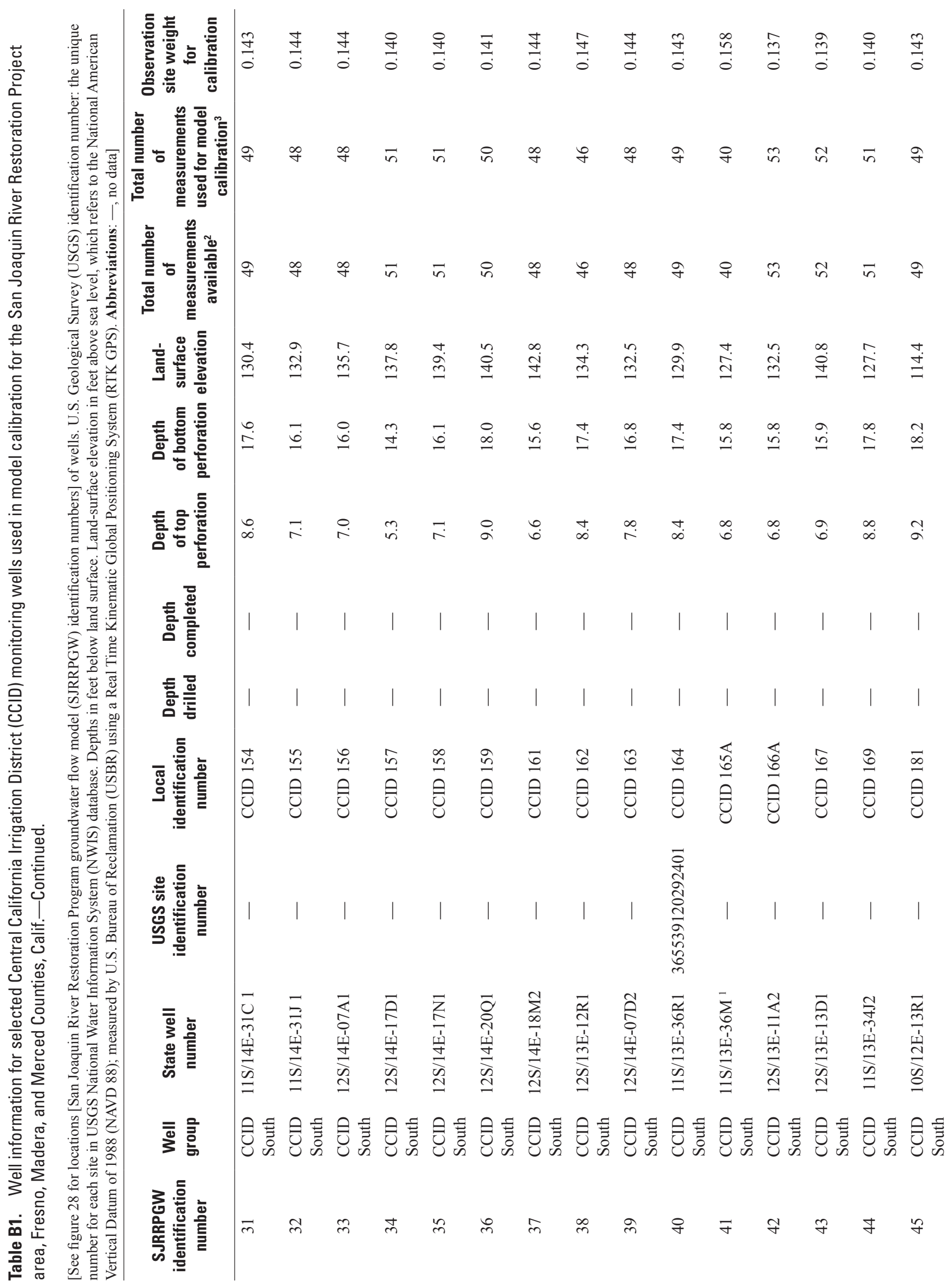




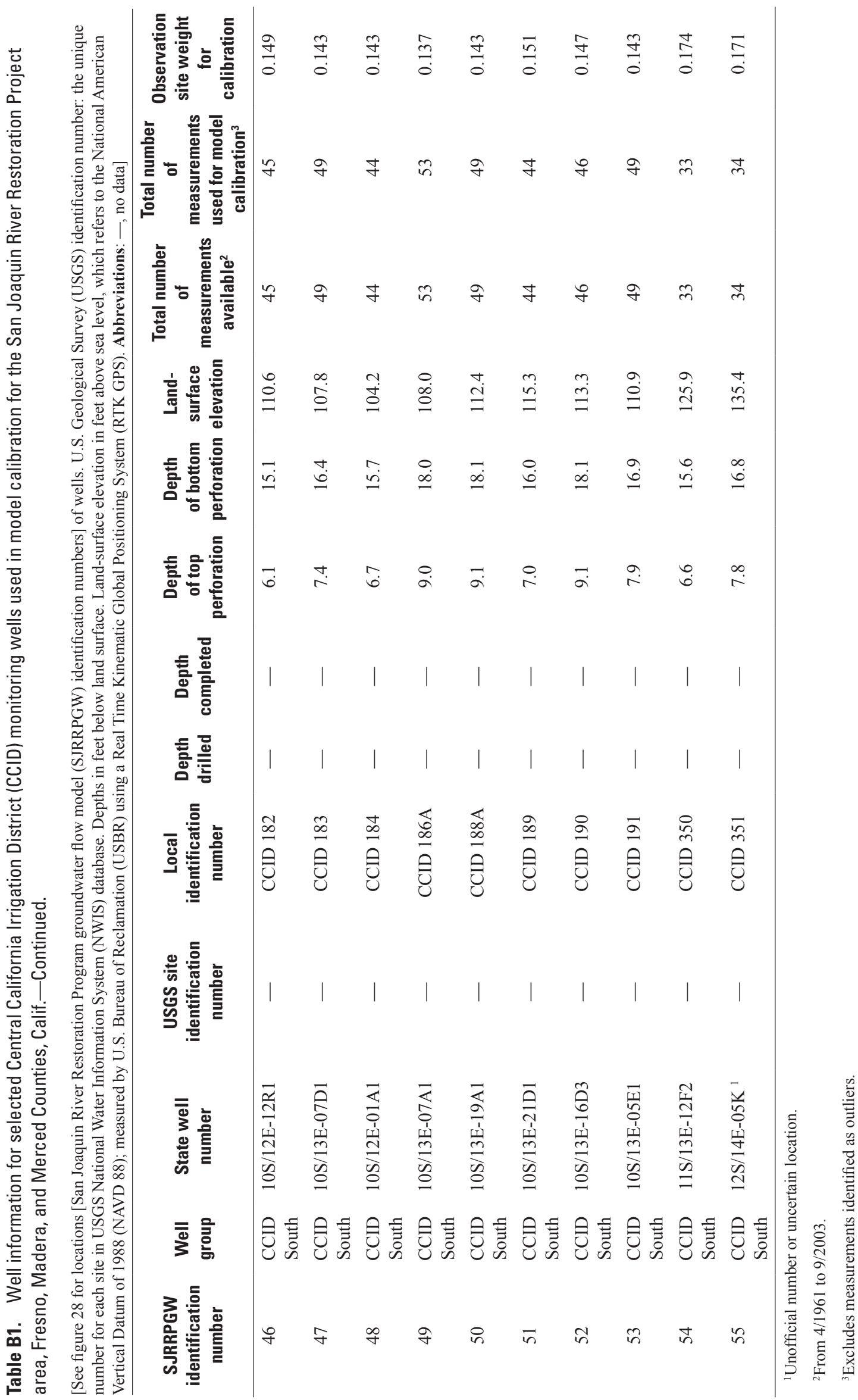




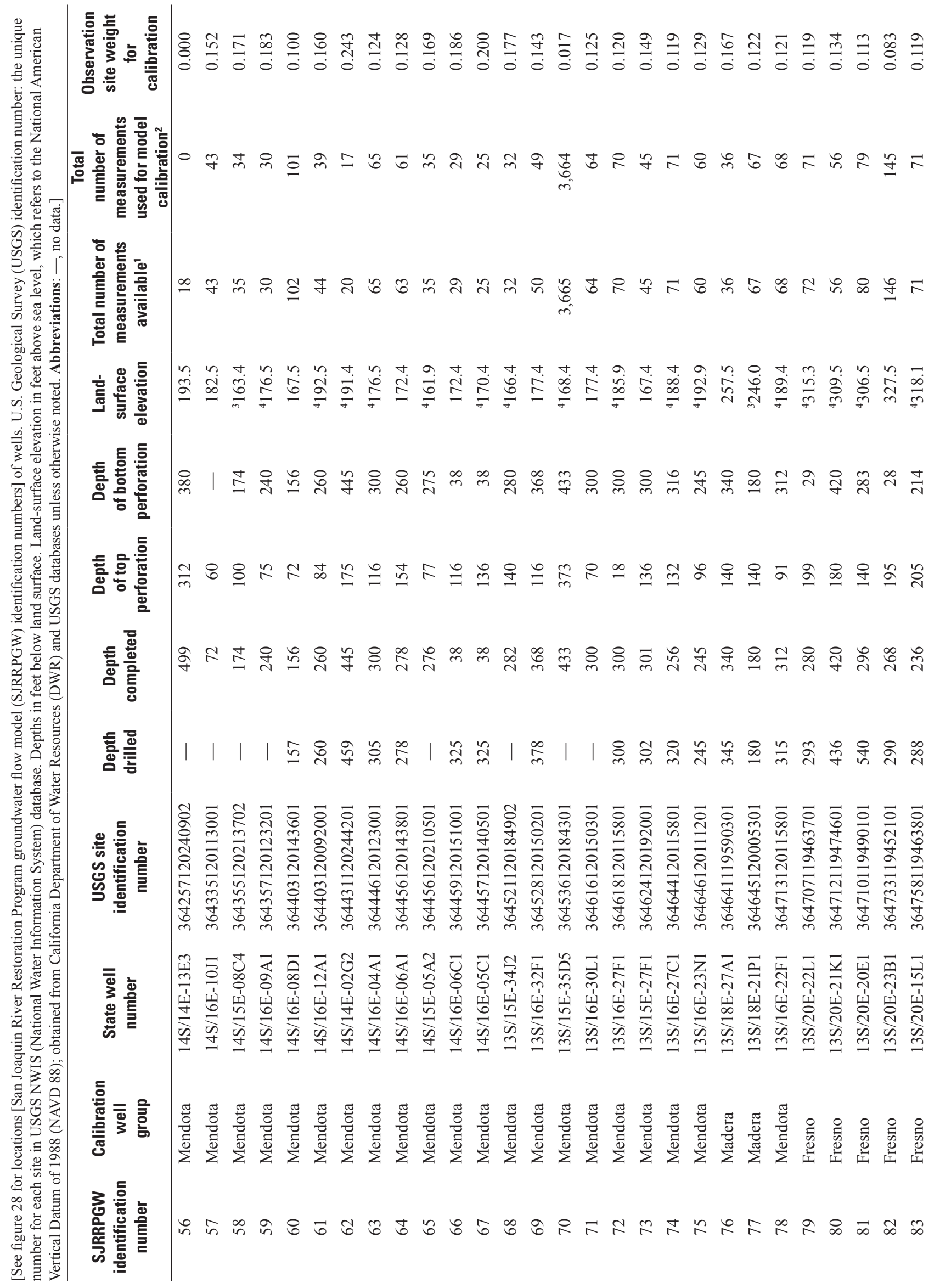




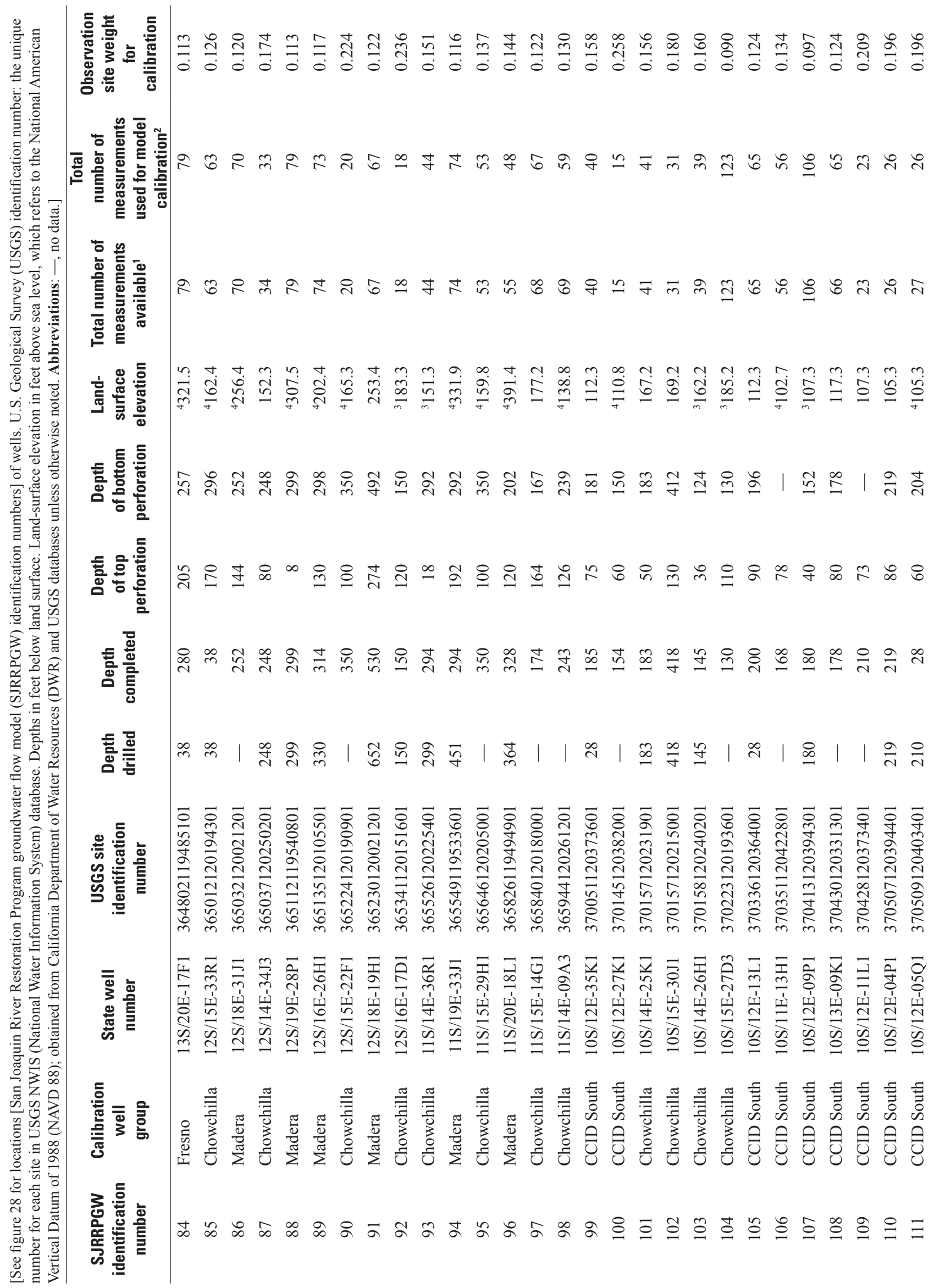




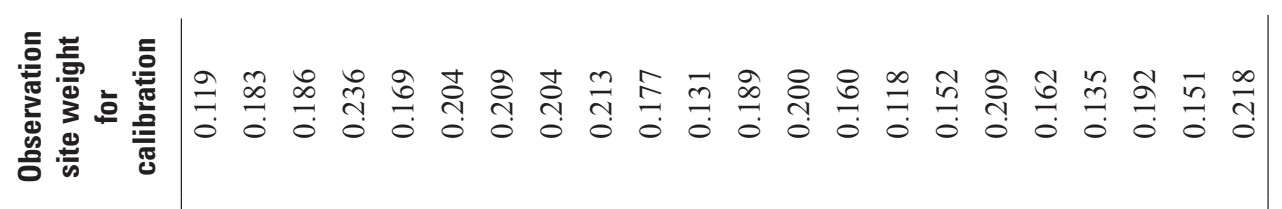

要

焉

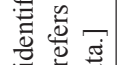

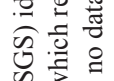

$\underbrace{2}$

突离

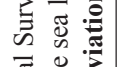

तु

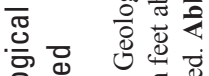

응 일

ब.

$\dot{\varphi}: \Xi \frac{0}{0}$

琵总

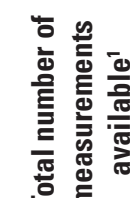

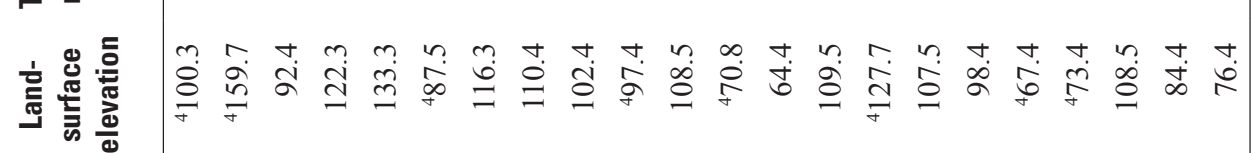

ஸे

등

孚

宁

ఏ 


\section{Appendix C. Calibration Results}

This appendix shows the relation between the simulated and observed groundwater elevations at all 113 calibration wells (fig. C-1) and the simulated and observed streamflow at all 19 calibration streamgages (fig. C-2). Differences between observed and simulated groundwater elevations are expected in a calibrated groundwater model. Overall, the simulated groundwater-level elevations and trends and surface-water flow magnitudes and trends reasonably matched observed data for a regional model of this scale. 
A Calibration well 1

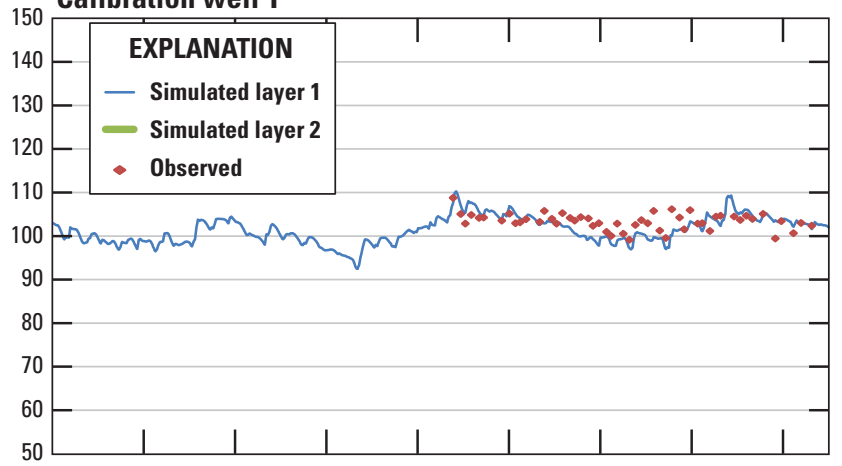

Calibration well 2

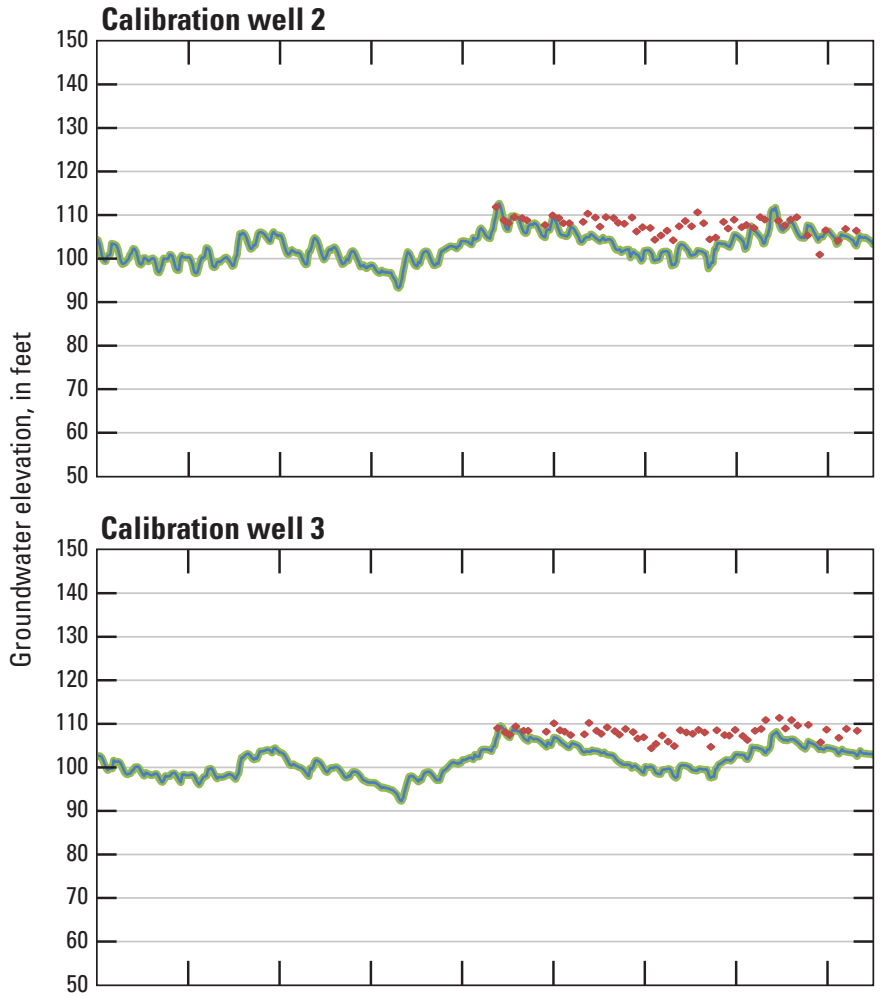

Calibration well 4

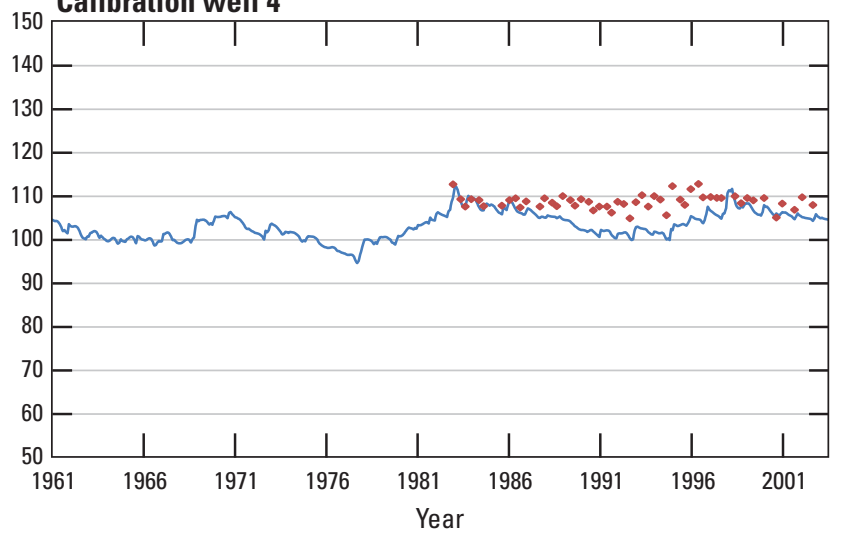

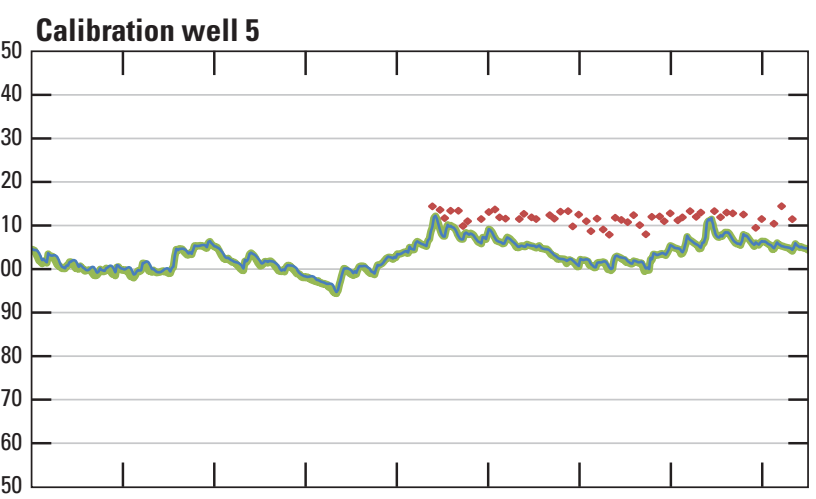

Calibration well 6

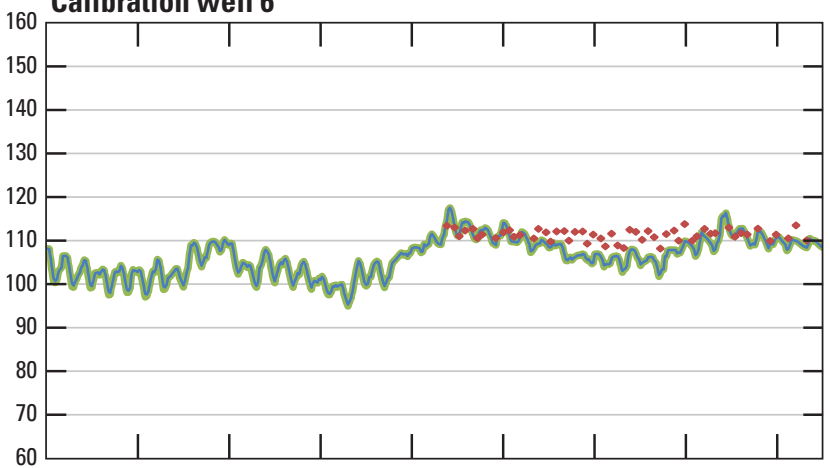

Calibration well 7

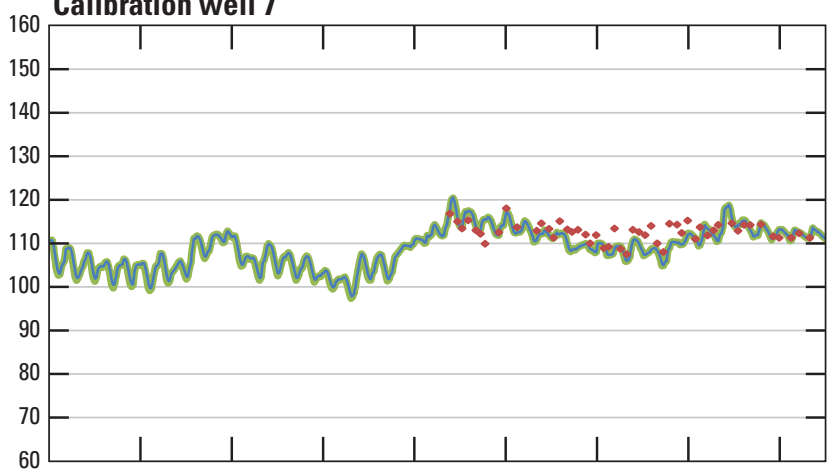

Calibration well 8

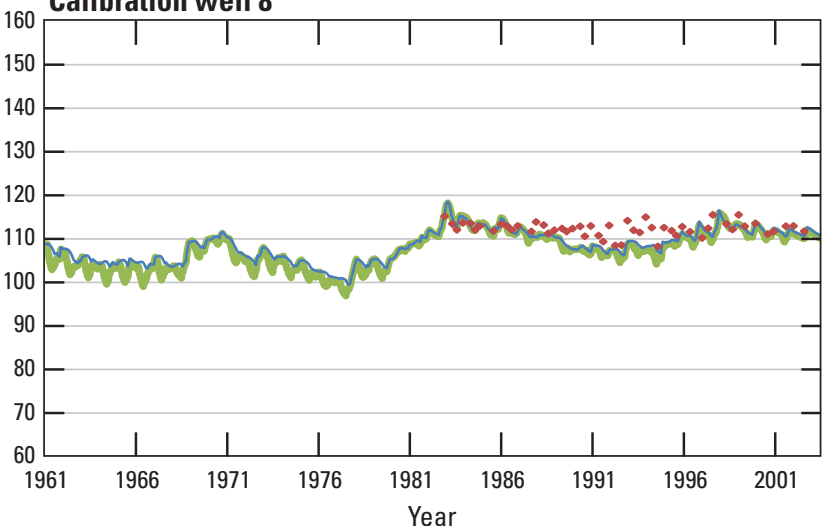

Figure C-1. Hydrographs showing simulated and observed groundwater elevations at each calibration well in the San Joaquin valley, 1961-2001: $A$, calibration wells 1-8; $B$, calibration wells 9-16; $C$, calibration wells 17-24; $D$, calibration wells 25-32; $E$, calibration wells 33-40; F, calibration wells 41-48; G, calibration wells 49-56; $H$, calibration wells 57-64; I, calibration wells 65-72; J, calibration wells 73-80; $K$, calibration wells 81-88; $L$, calibration wells 89-96; $M$, calibration wells 97-104; $N$, calibration wells 105-112; 0, calibration wells 113-120; $P$, calibration wells 121-128; $Q$, calibration wells 129-133. 

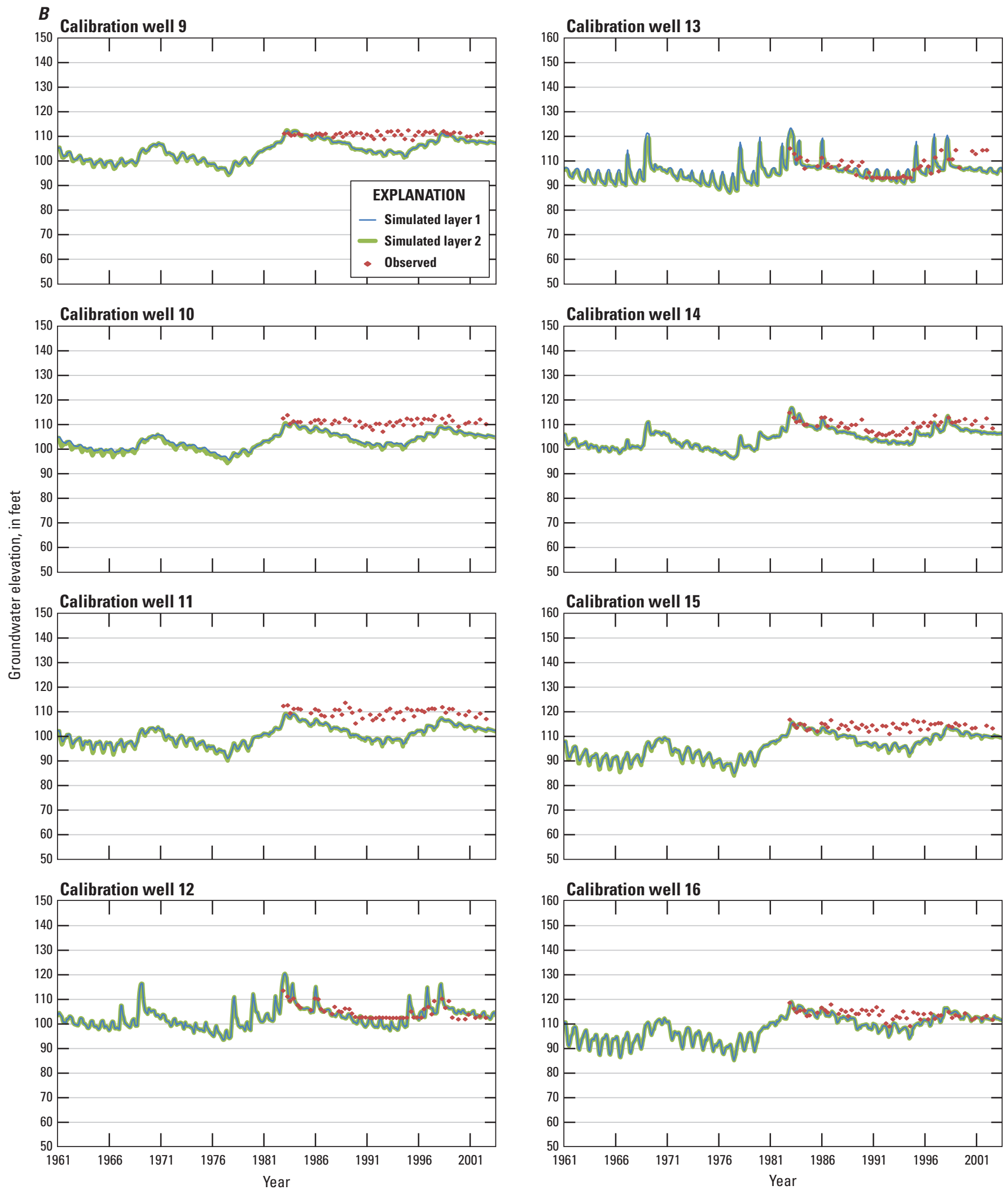

Figure C-1. - Continued 

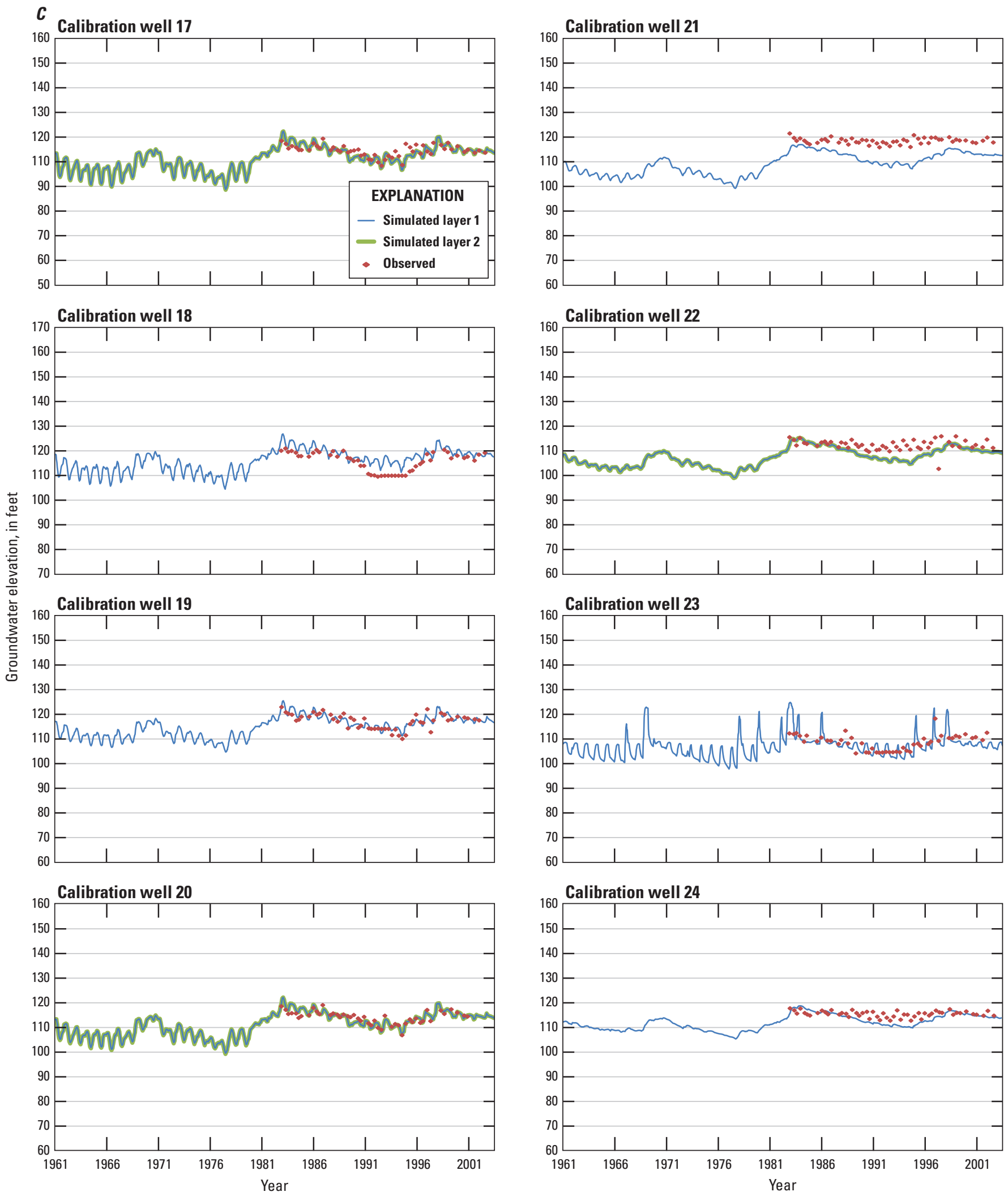

Figure C-1. -Continued 

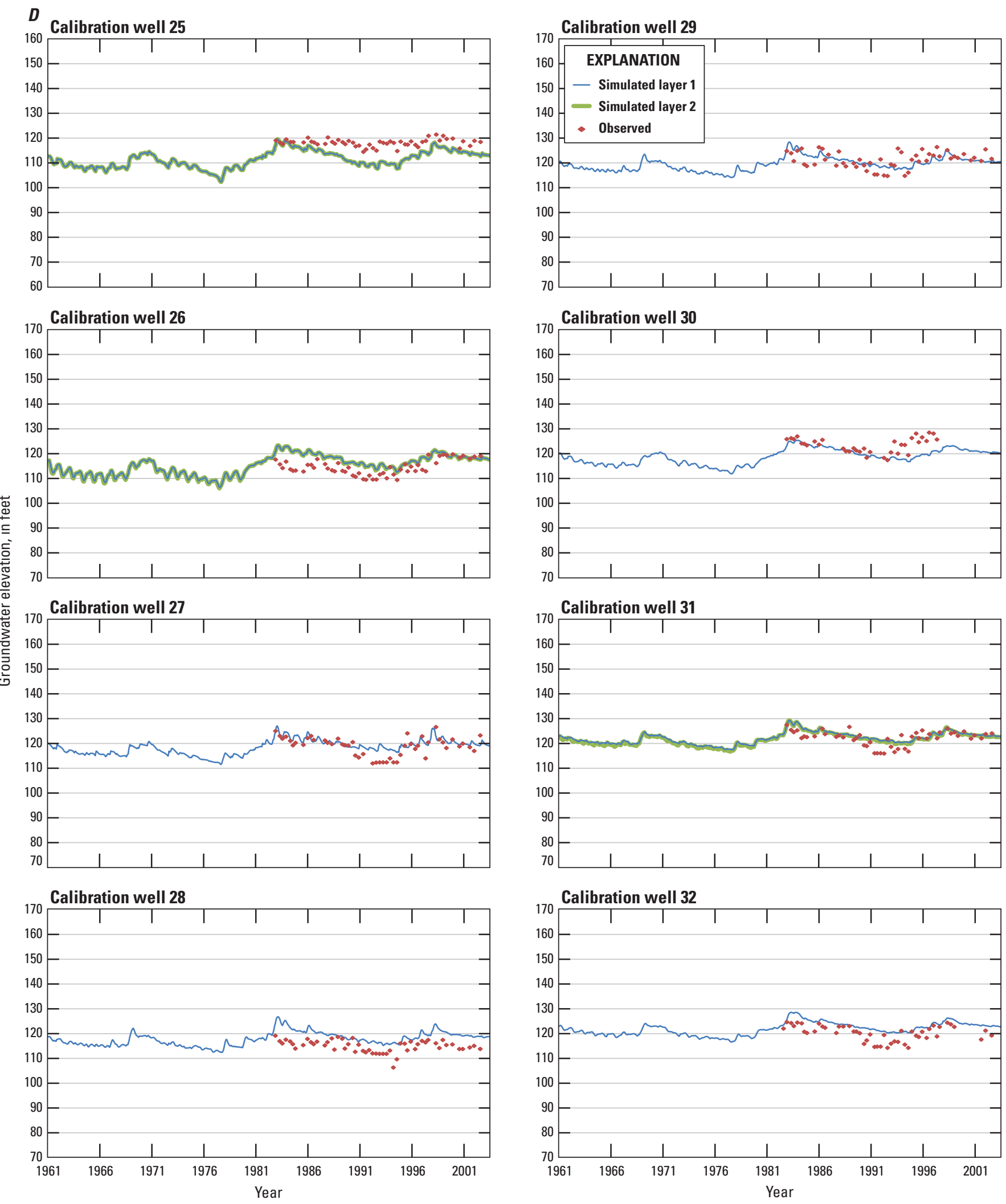

Figure C-1. - Continued 

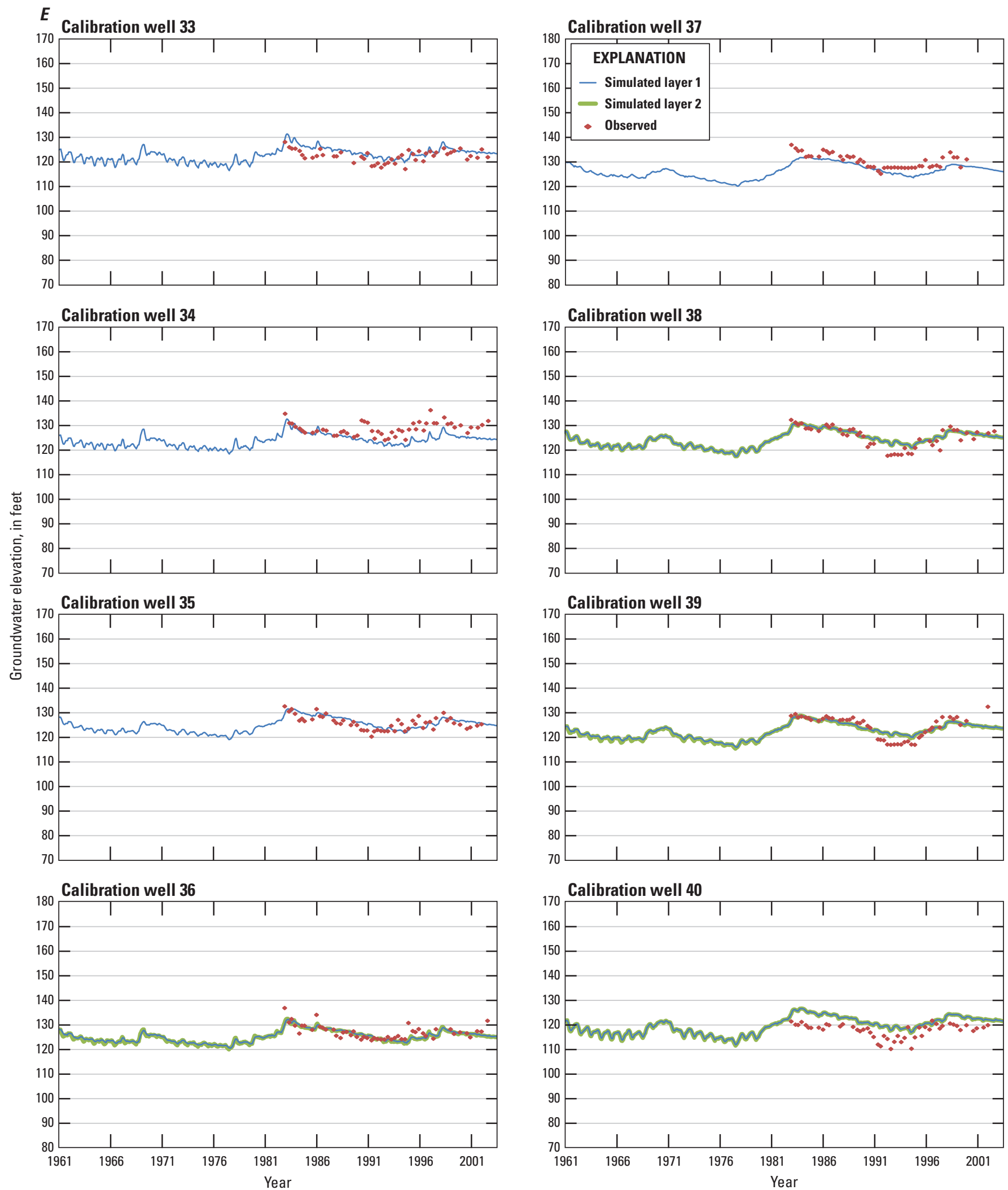

Figure C-1. - Continued 

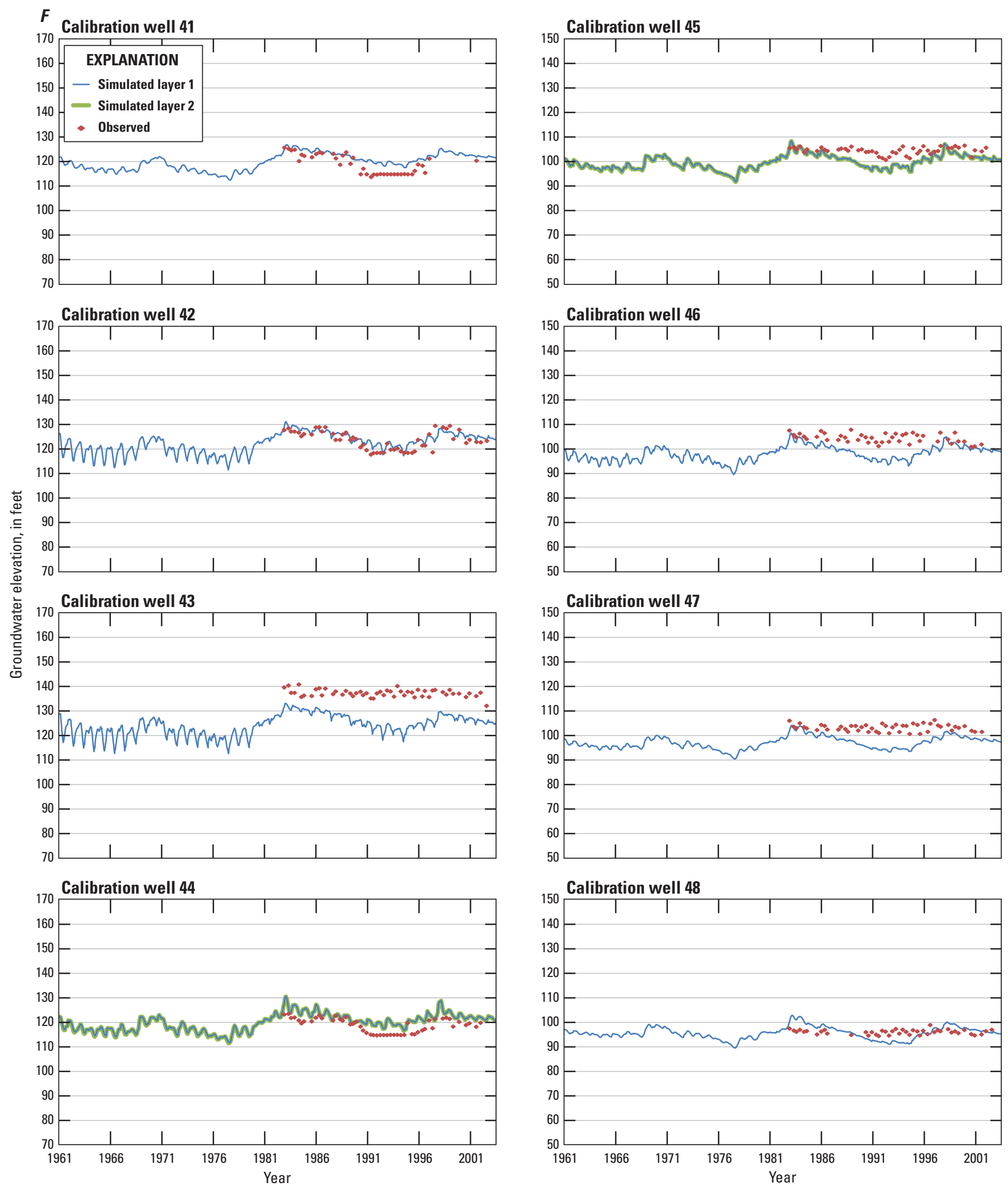

Figure C-1. - Continued 
6
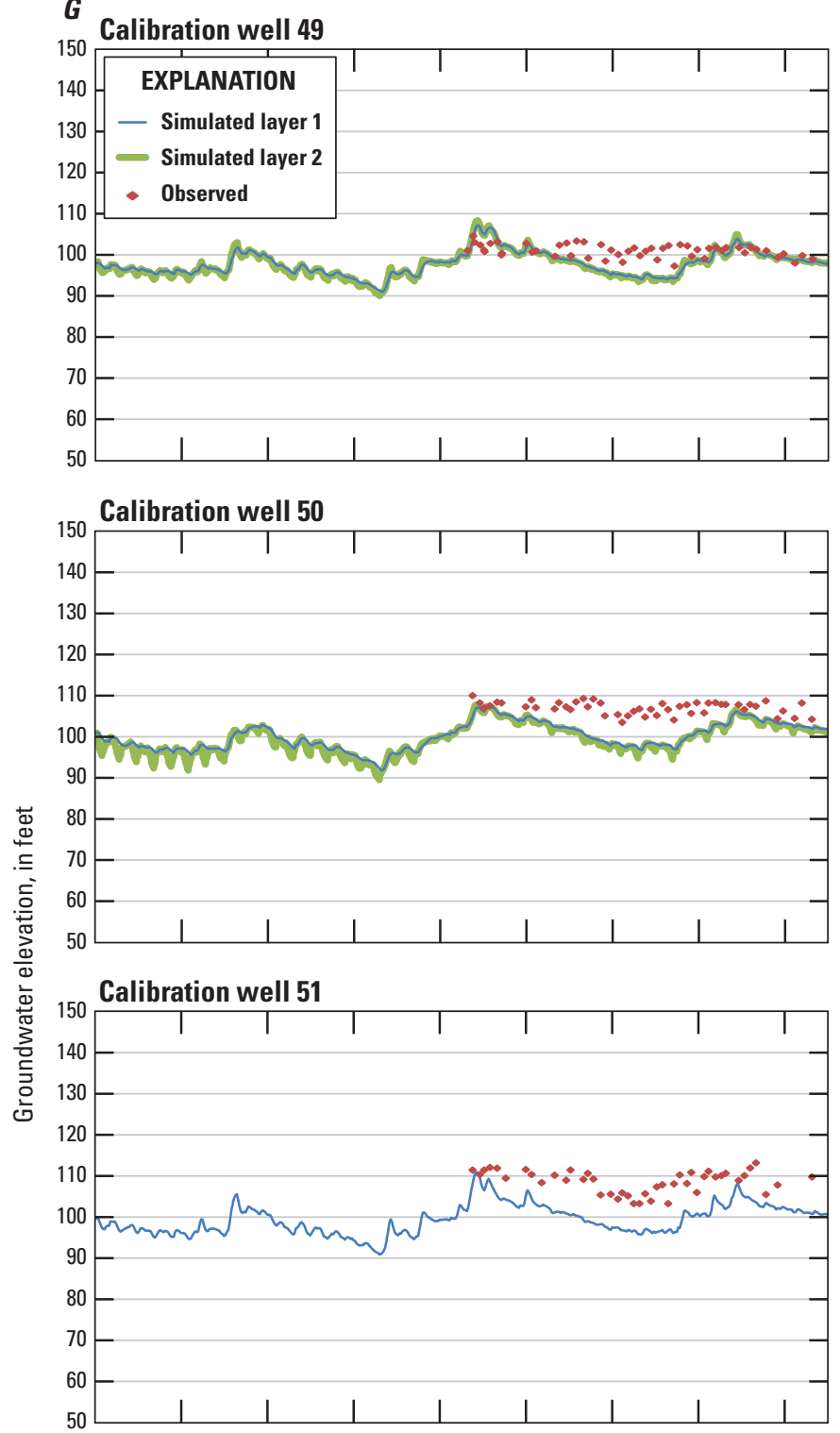

Calibration well 52

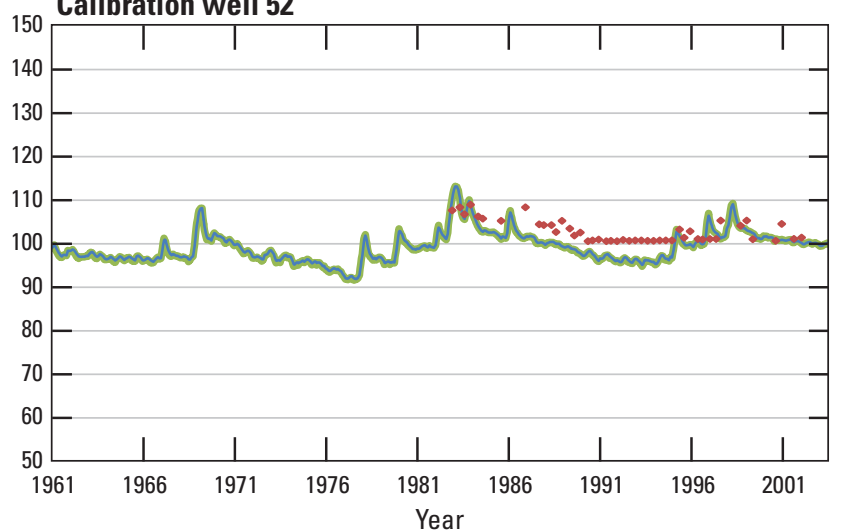

Calibration well 53

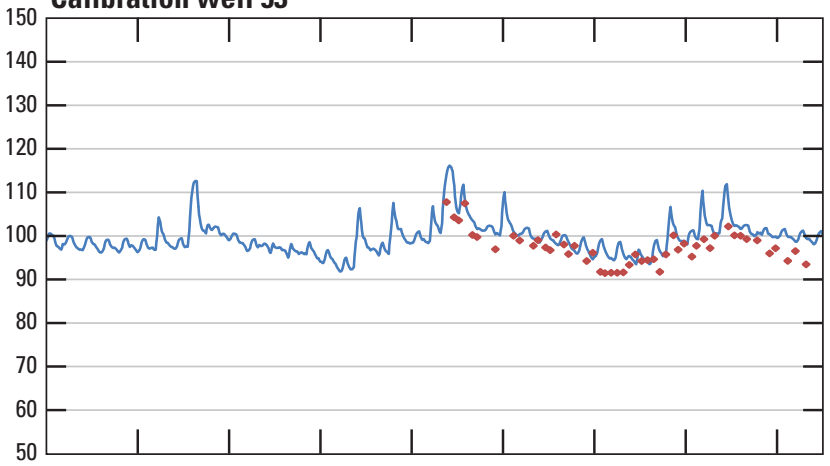

Calibration well 54

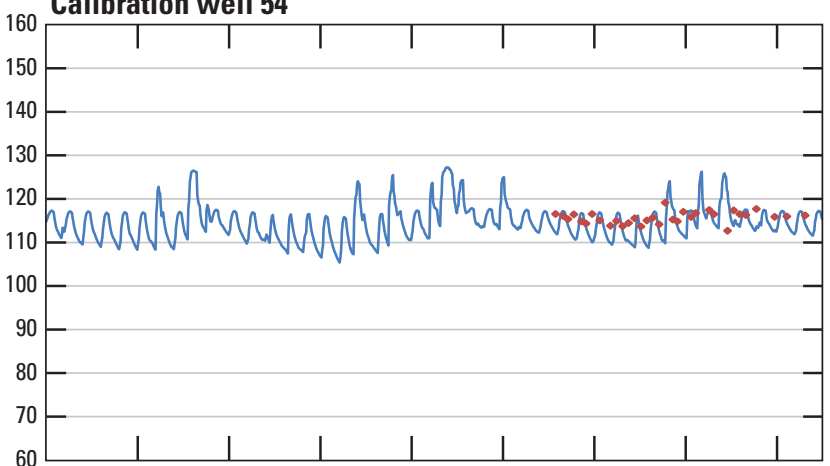

Calibration well 55
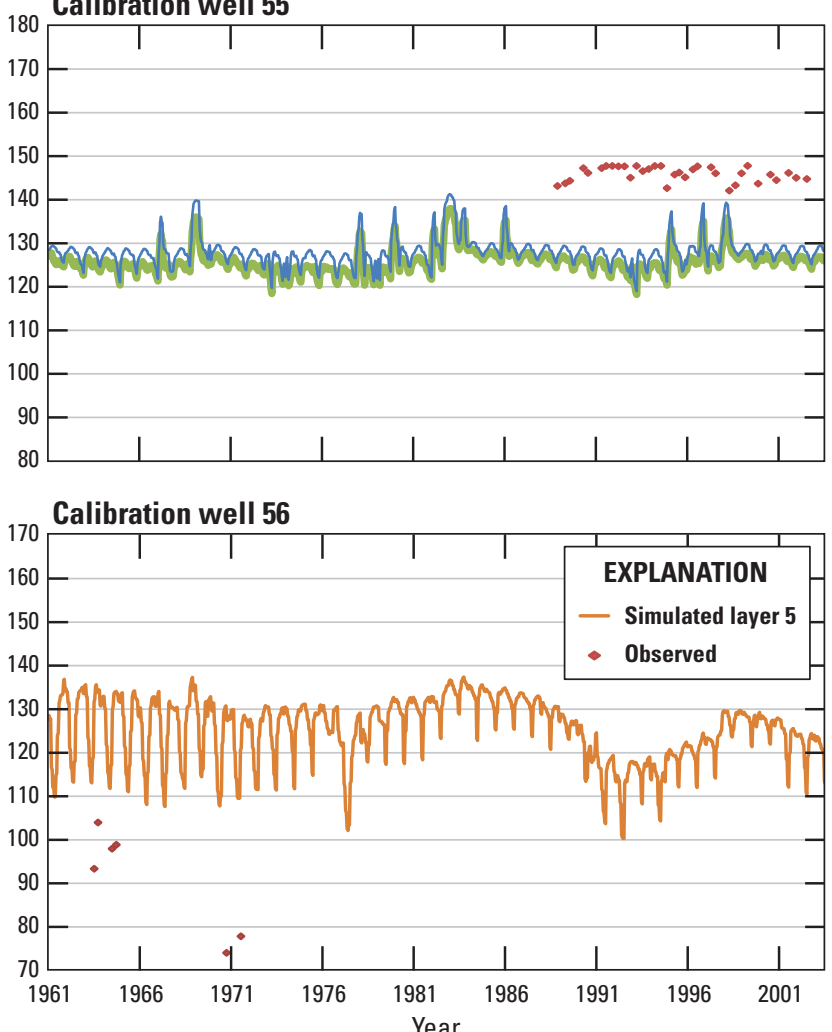

Figure C-1. - Continued 

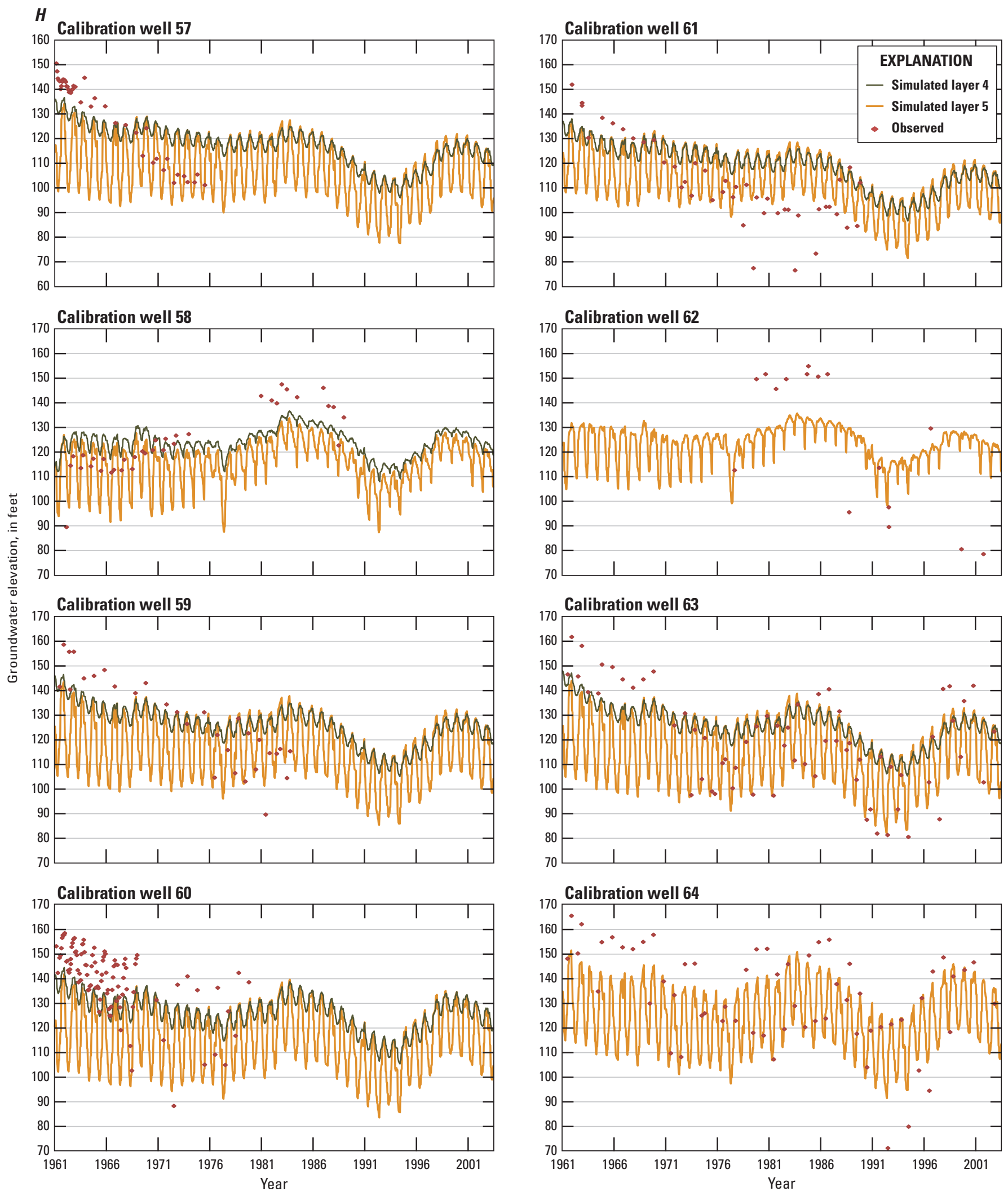

Figure C-1. - Continued 

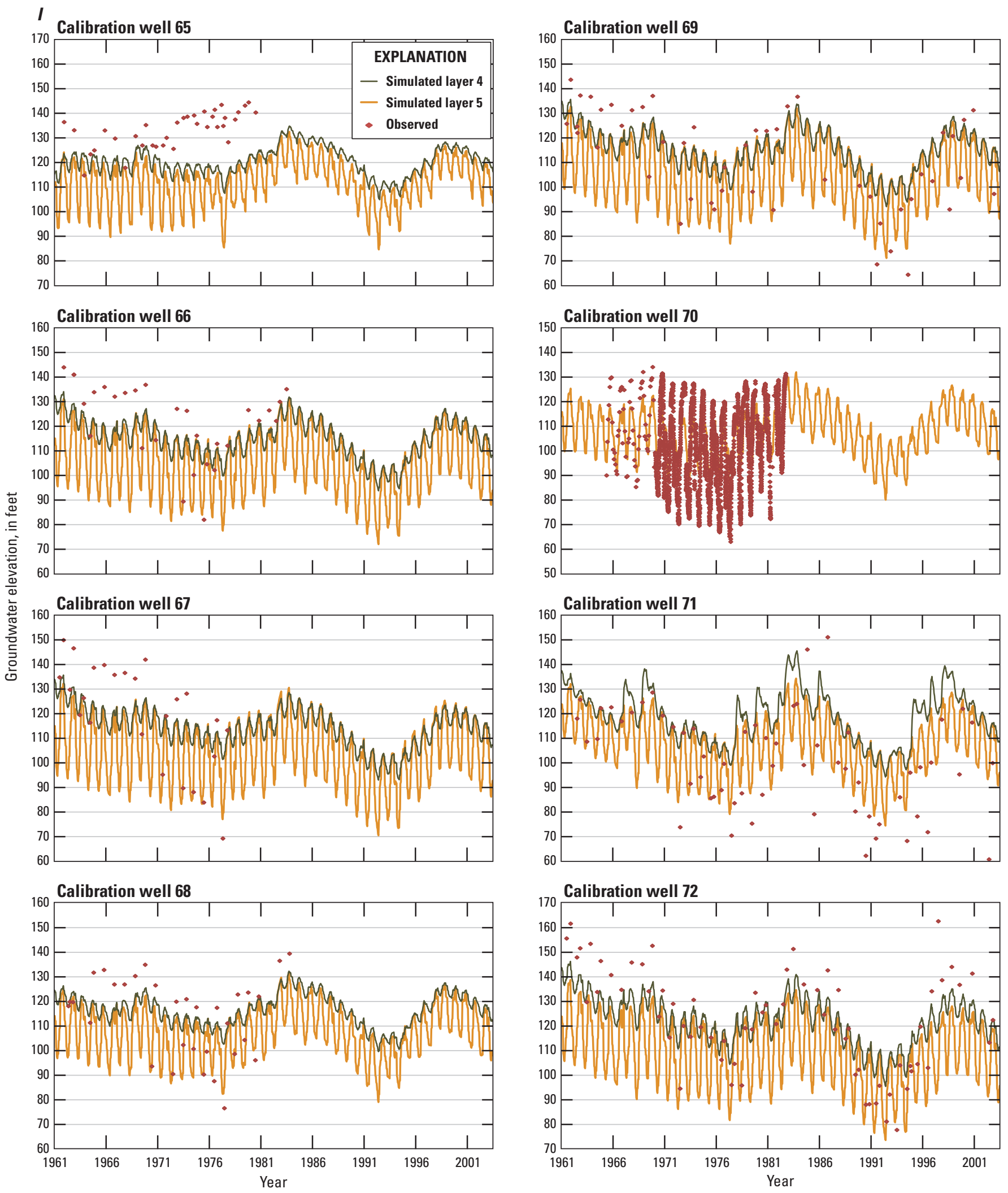

Figure C-1. - Continued 

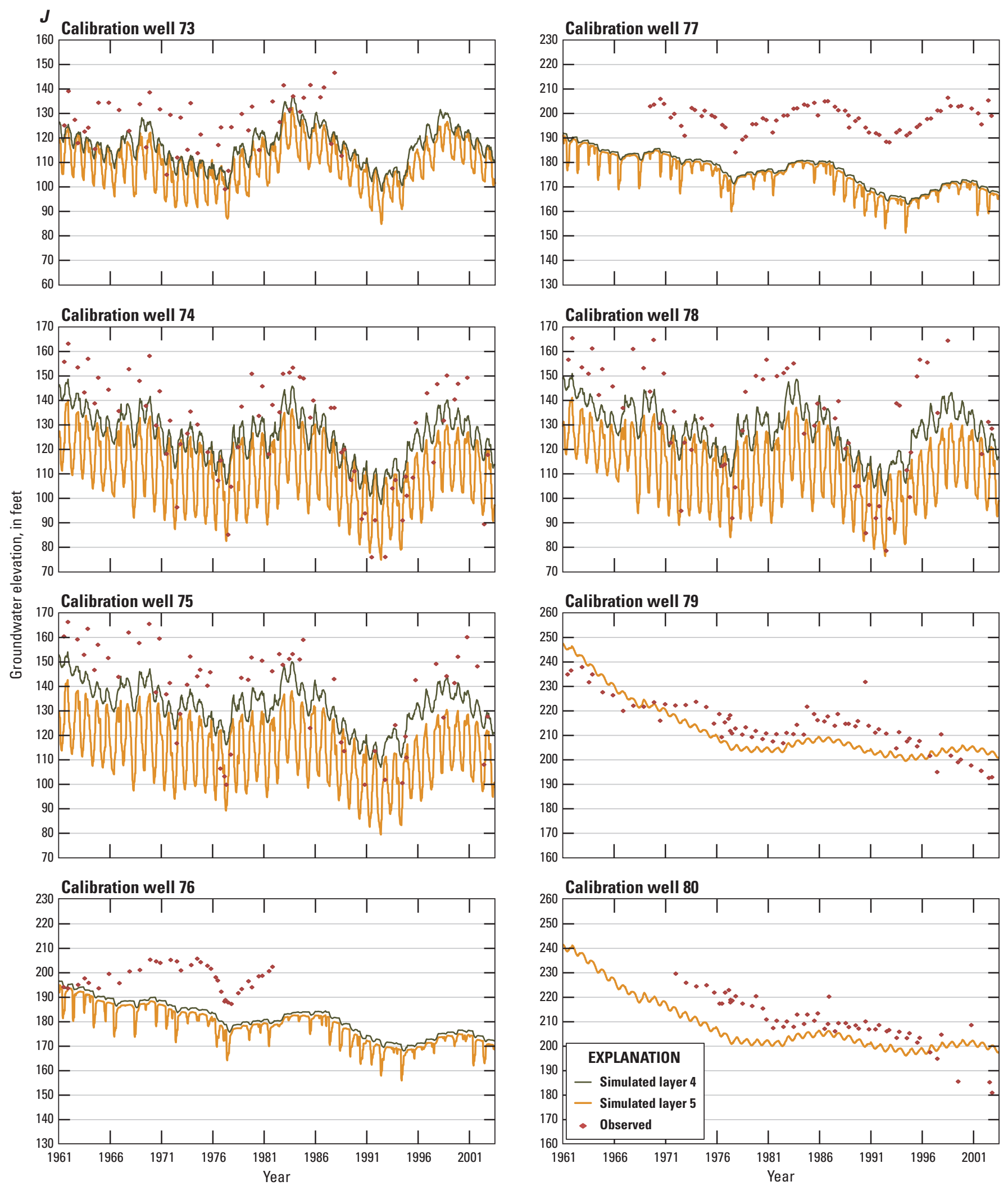

Figure C-1. - Continued 

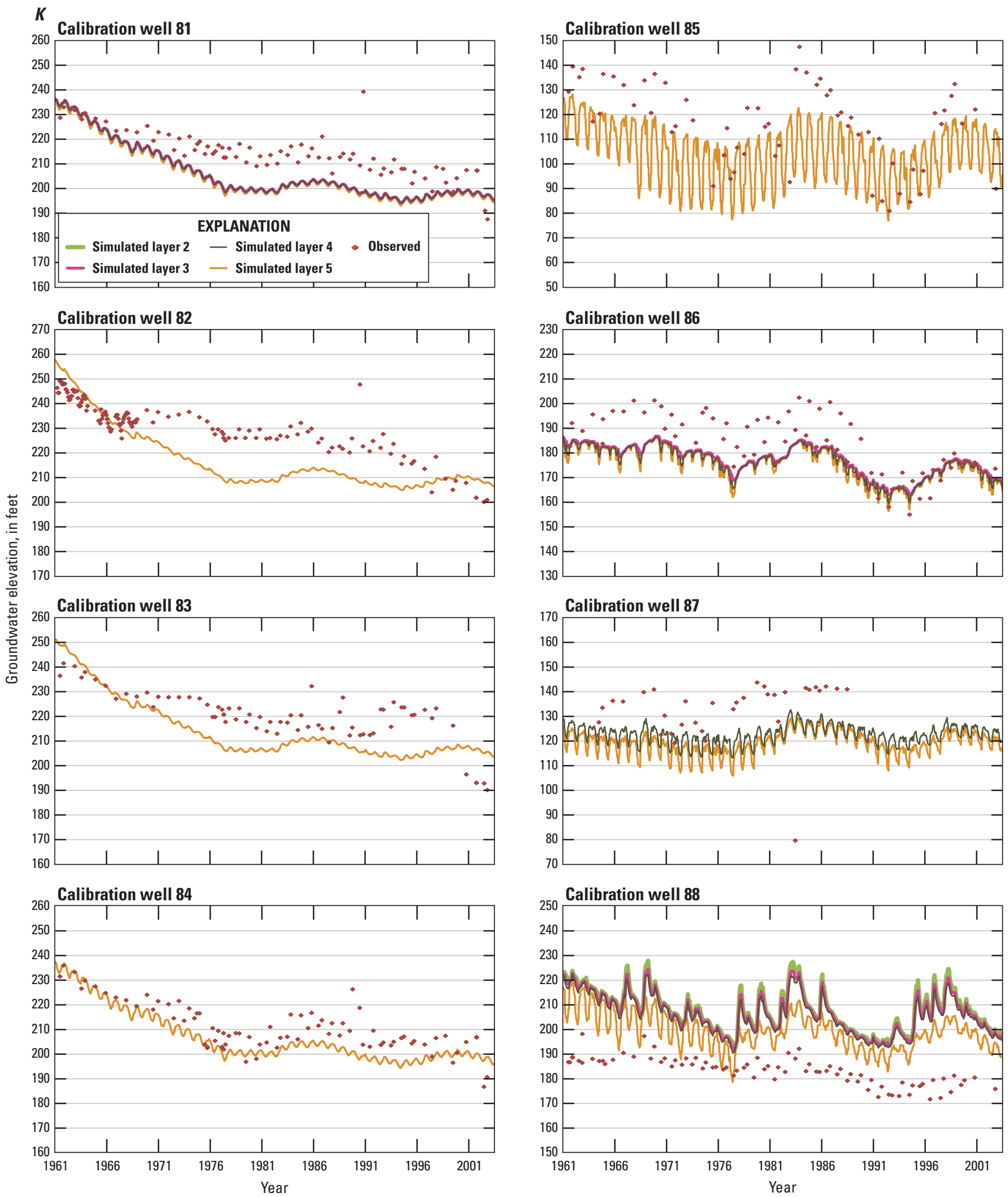

Figure C-1. - Continued 

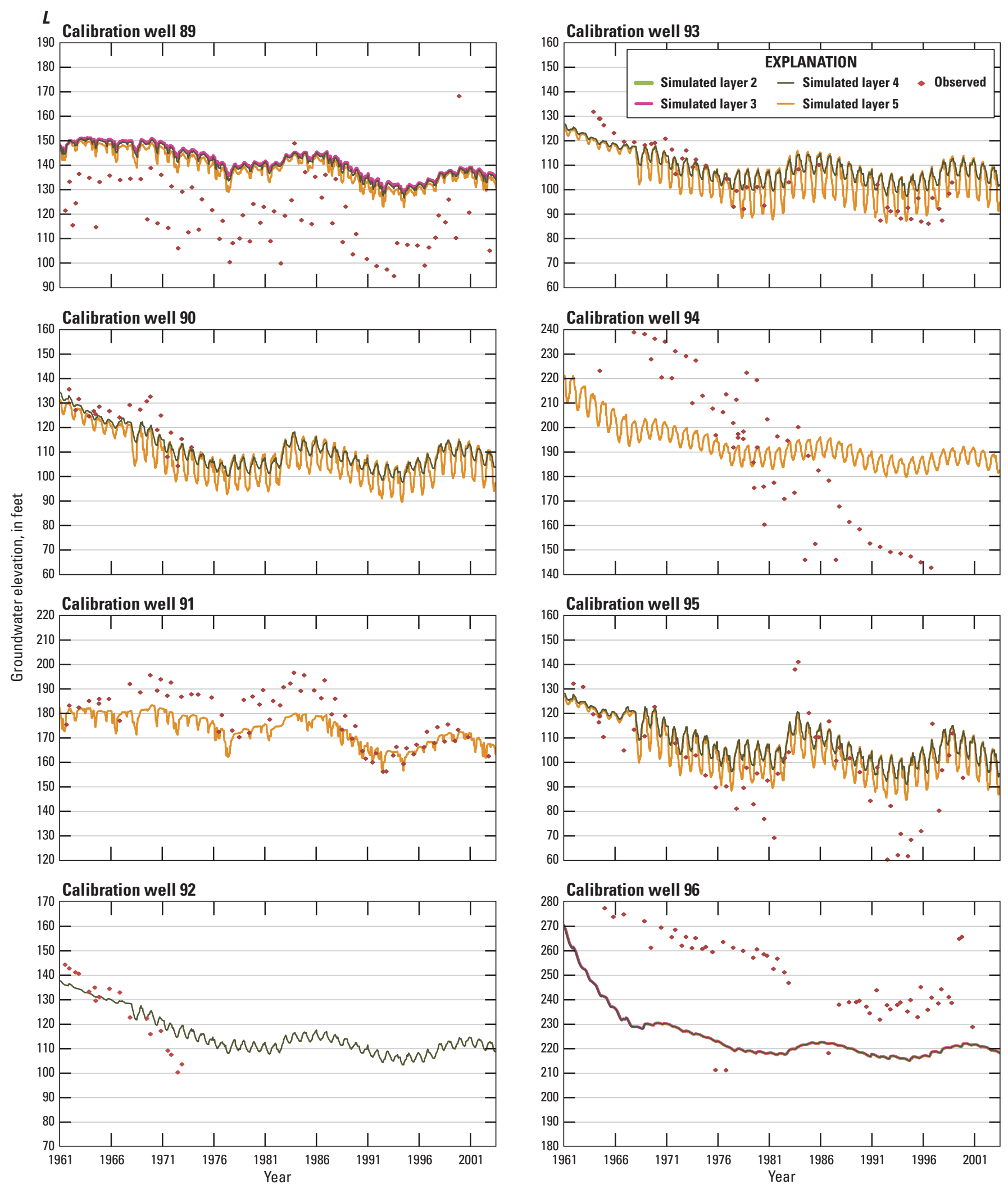

Figure C-1. - Continued 

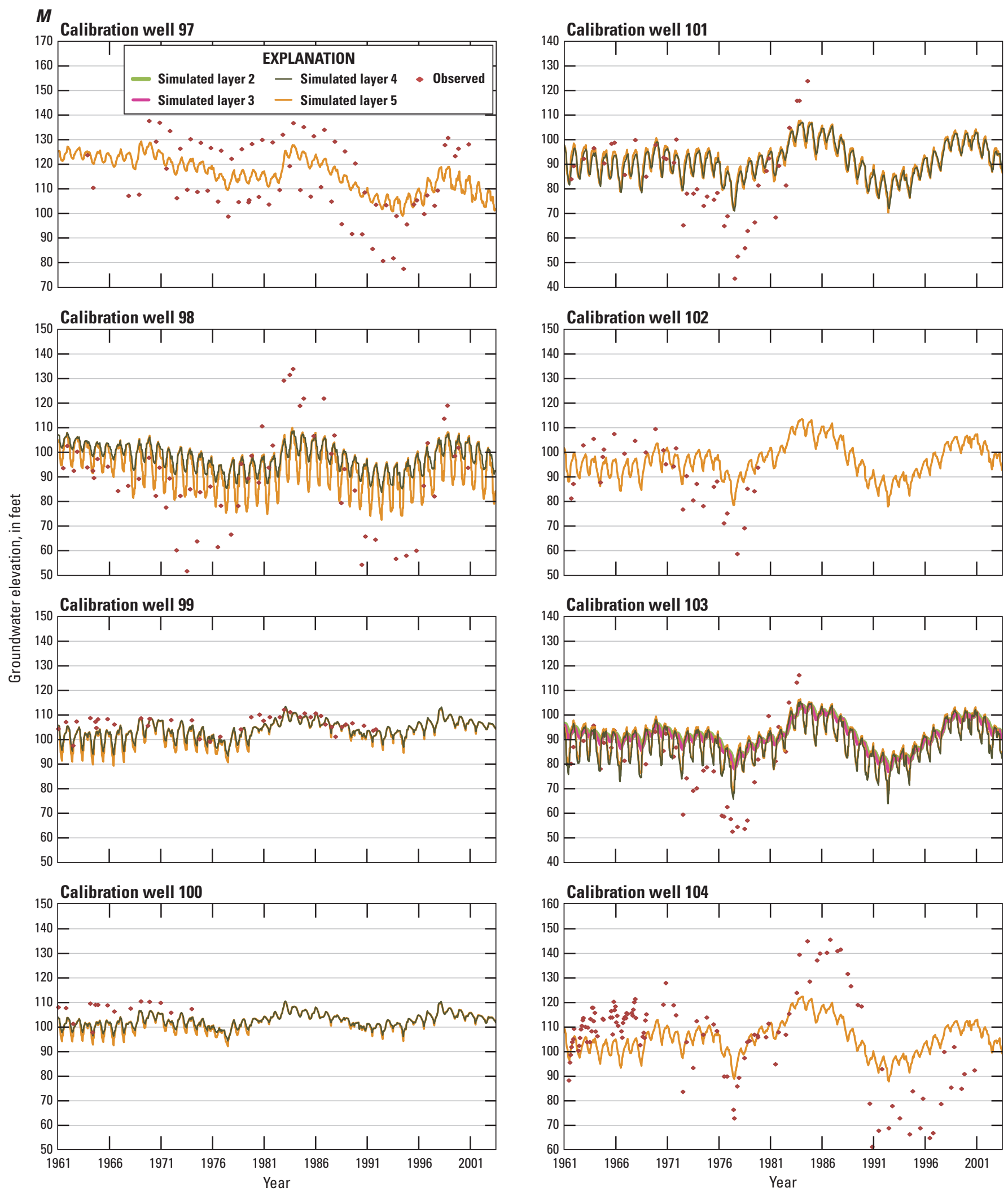

Figure C-1. - Continued 

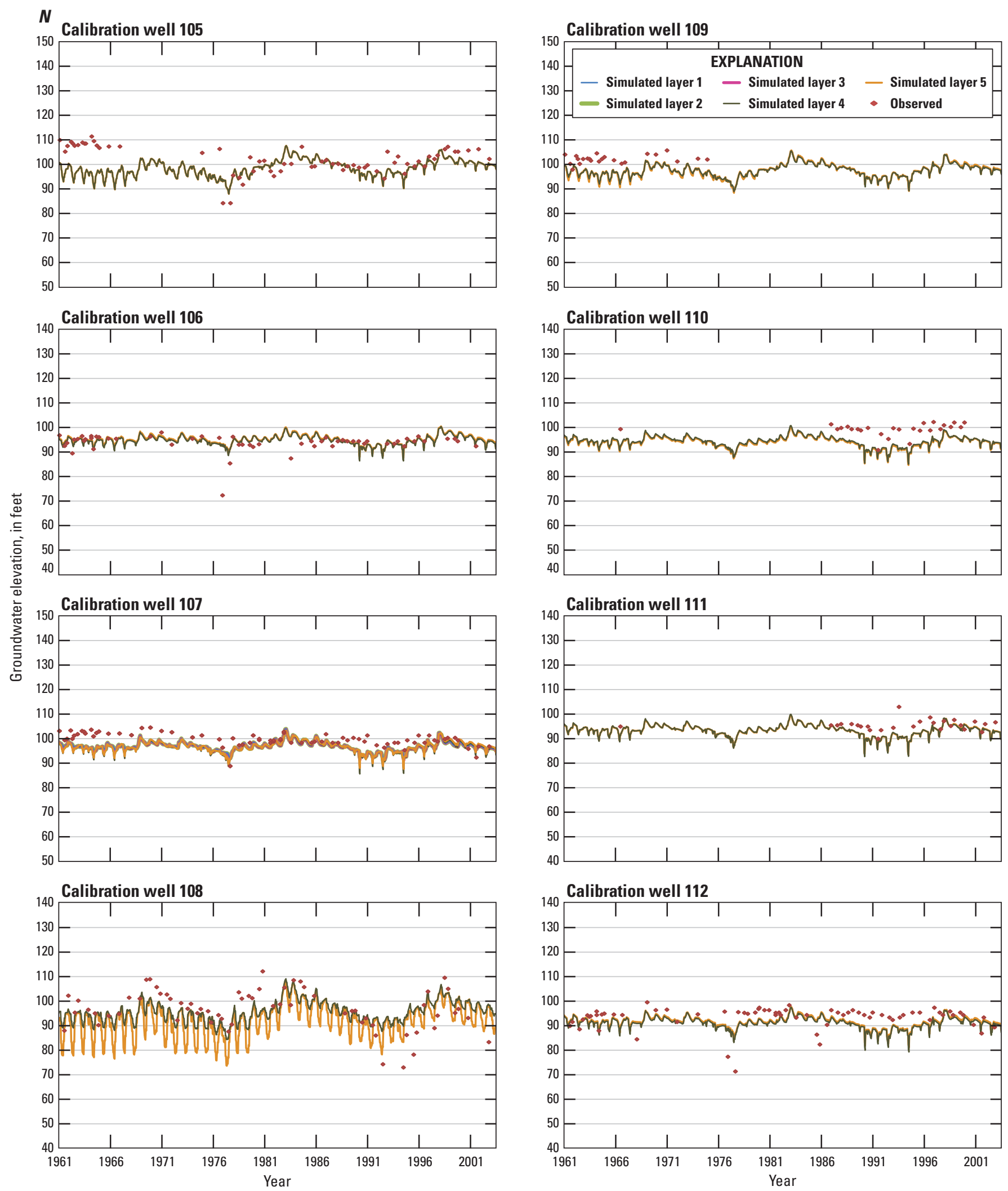

Figure C-1. - Continued 

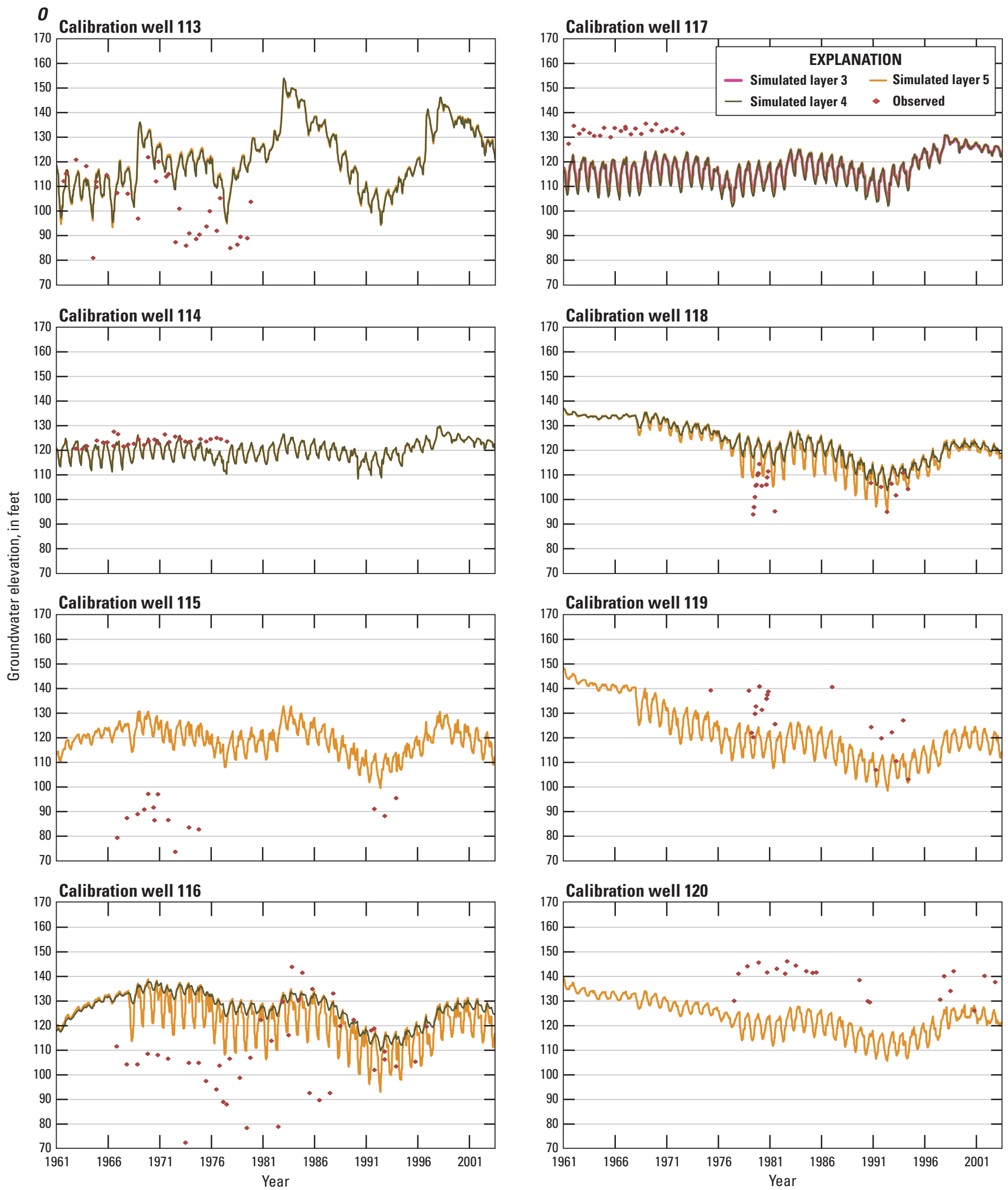

Figure C-1. - Continued 

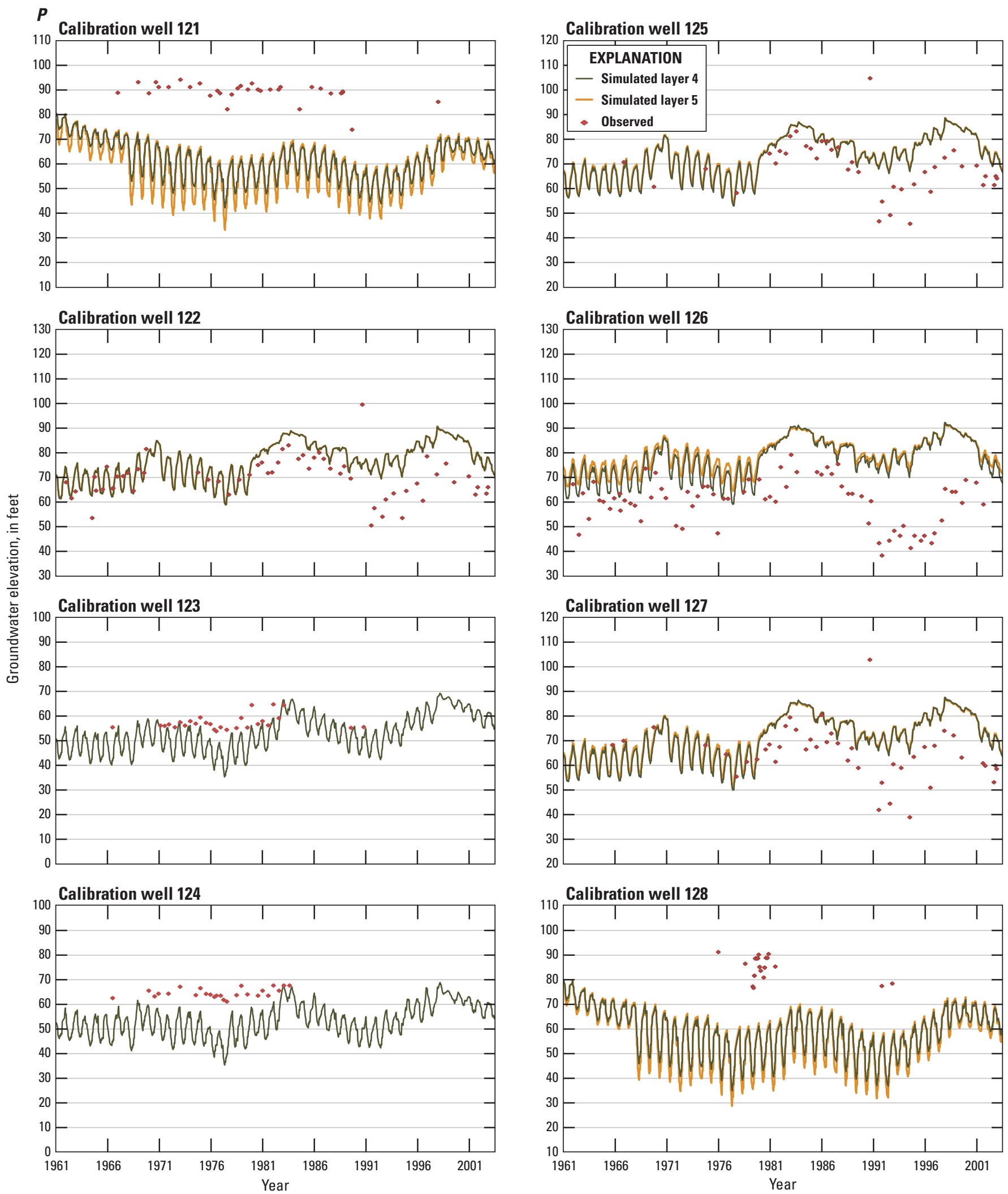

Figure C-1. - Continued 

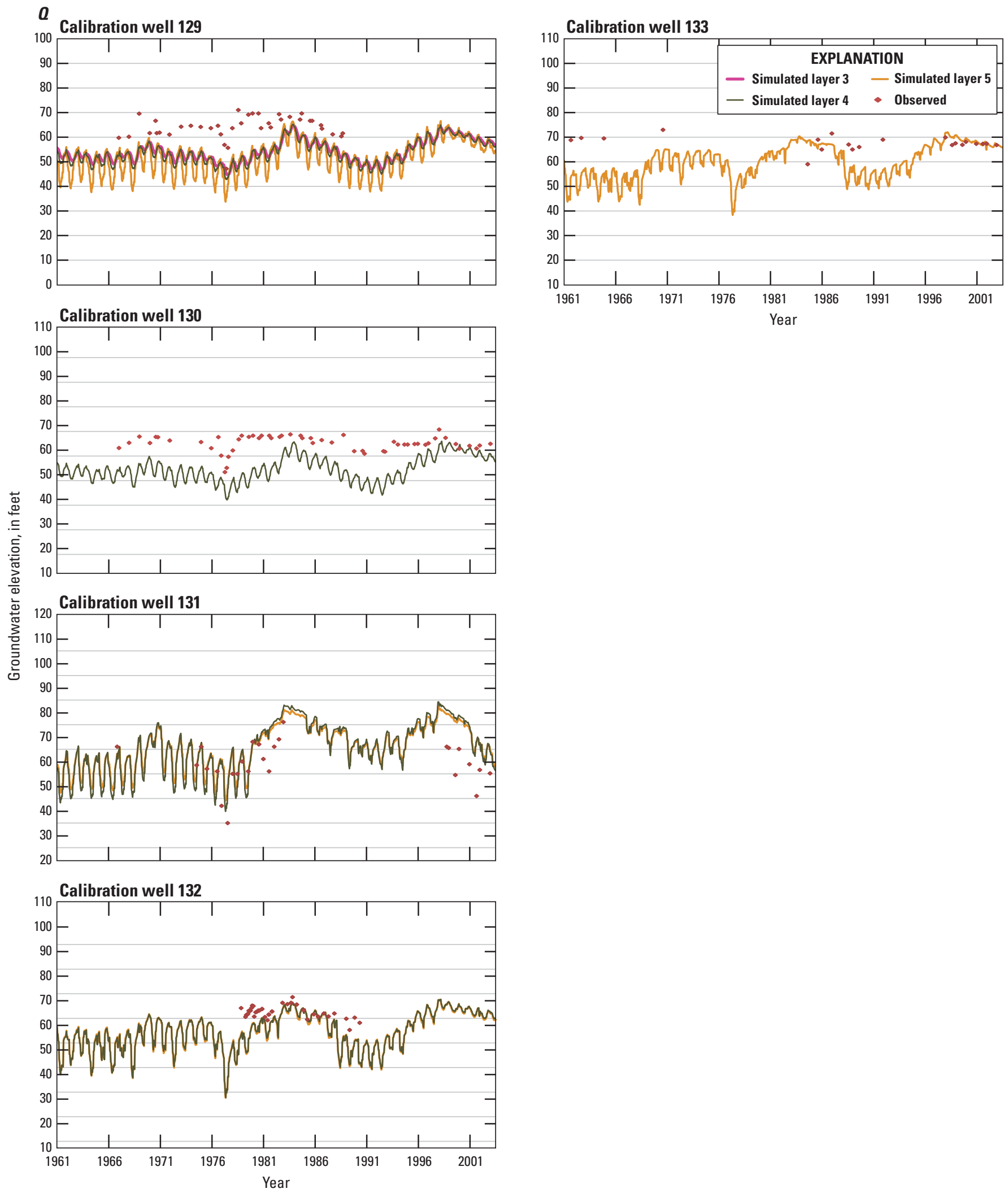

Figure C-1. - Continued 
A Streamgage 1: San Joaquin River near El Nido, California
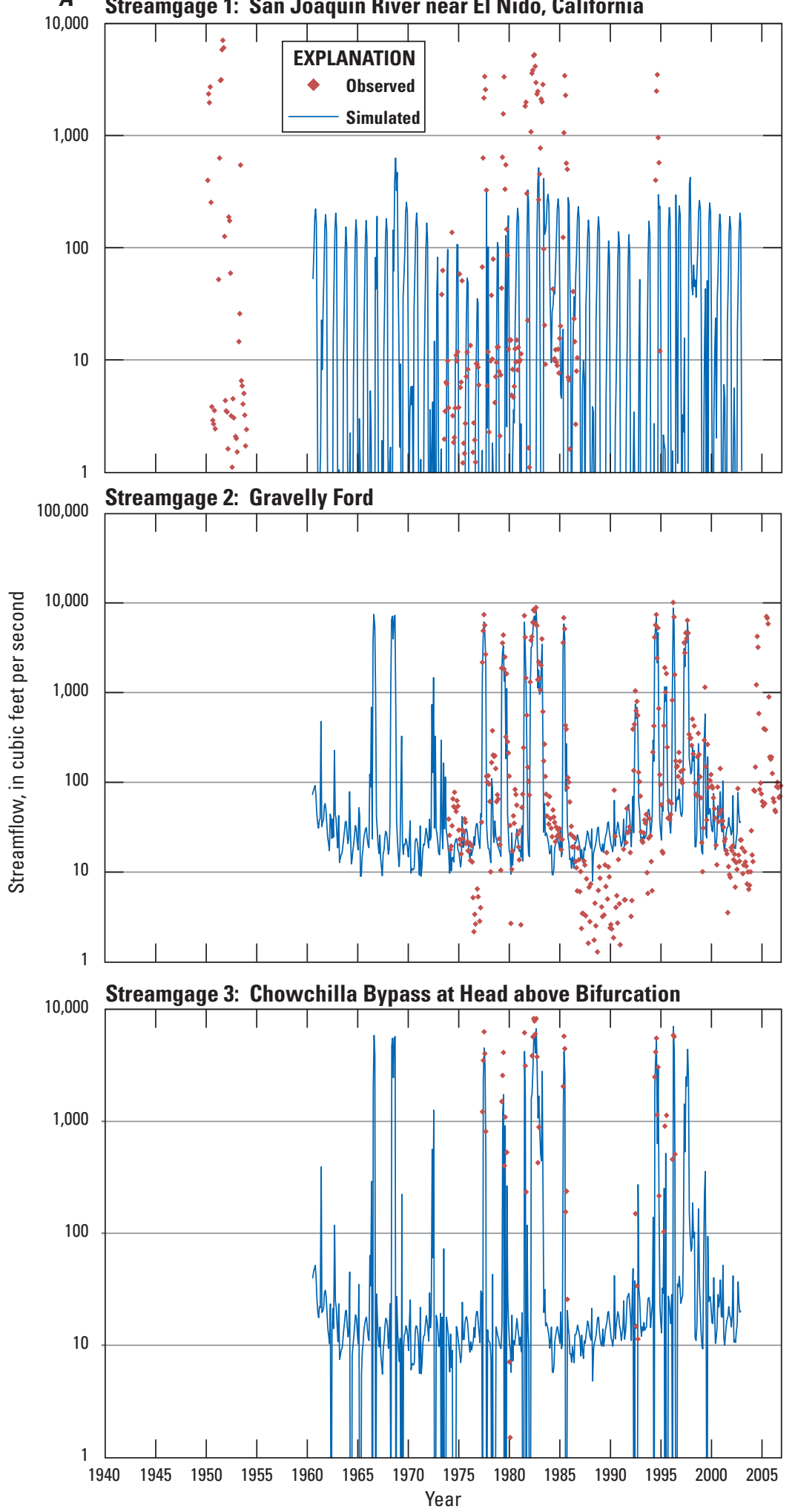

Figure C-2. Hydrographs showing differences between simulated and observed streamflow at all 19 calibration streamgages in the San Joaquin valley, 1940-2005: A, San Joaquin River (SJR) near El Nido, Gravelly Ford, and Chowchilla Bypass at Head above Bifurcation; $B$, SJR below Bifurcation, SJR near Mendota, and SJR near Dos Palos; $C$, Eastside bypass near El Nido, SJR near El Nido, and Eastside Bypass below Mariposa Bypass; D, Bear Creek below Eastside Canal, SJR near Stevinson, and Salt Slough at Highway 165 near Stevinson; E, SJR at Fremont Ford Bridge, Mud Slough near Gustine, and Merced River near Stevinson; F, SJR near Newman, Donney Bridge, and Mariposa Bypass near Crane Ranch; G, SJR near Crows Landing. [Abbreviations: USBR, U.S. Bureau of Reclamation; USGS, U.S. Geological Survey] 

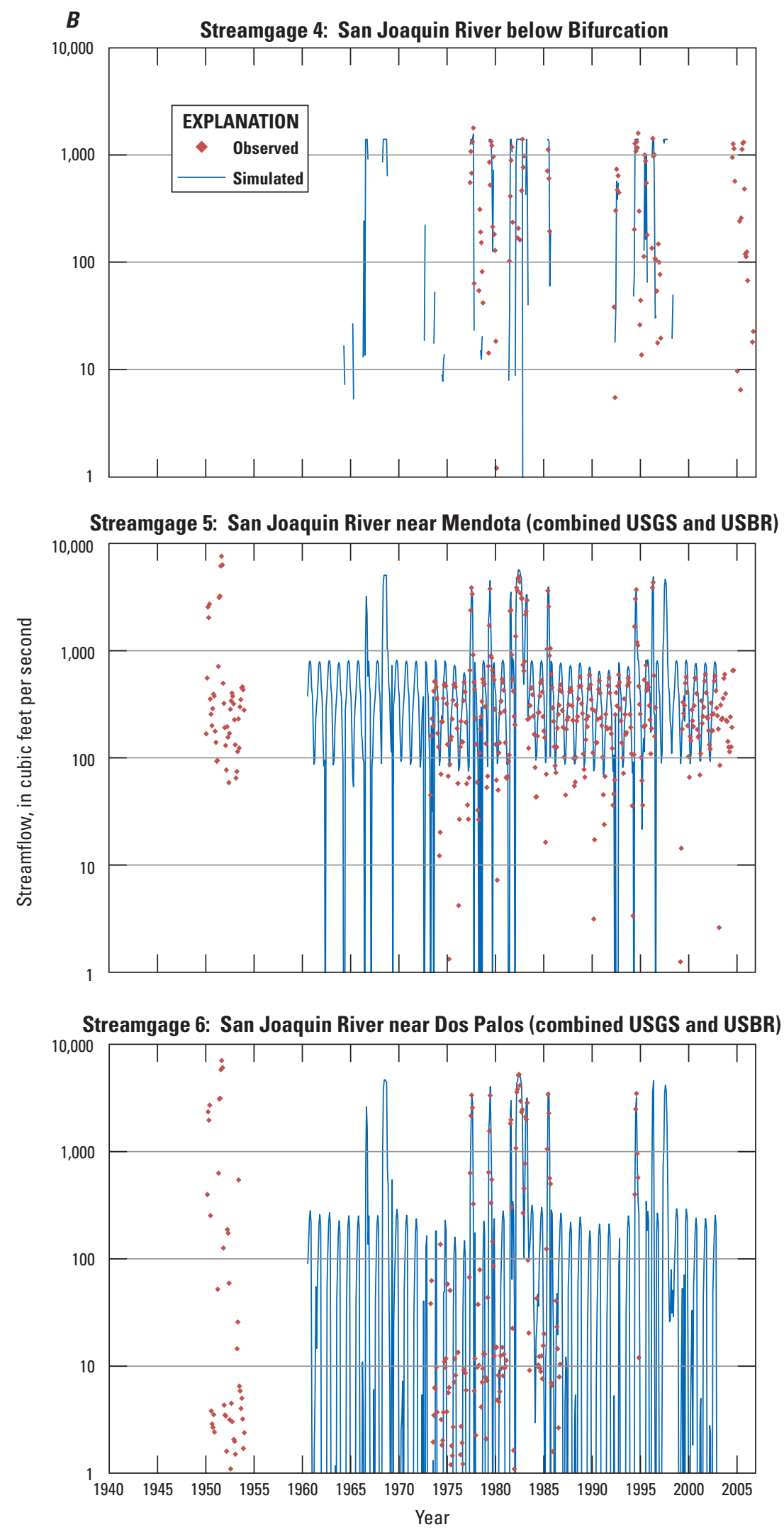

Figure C-2. - Continued 

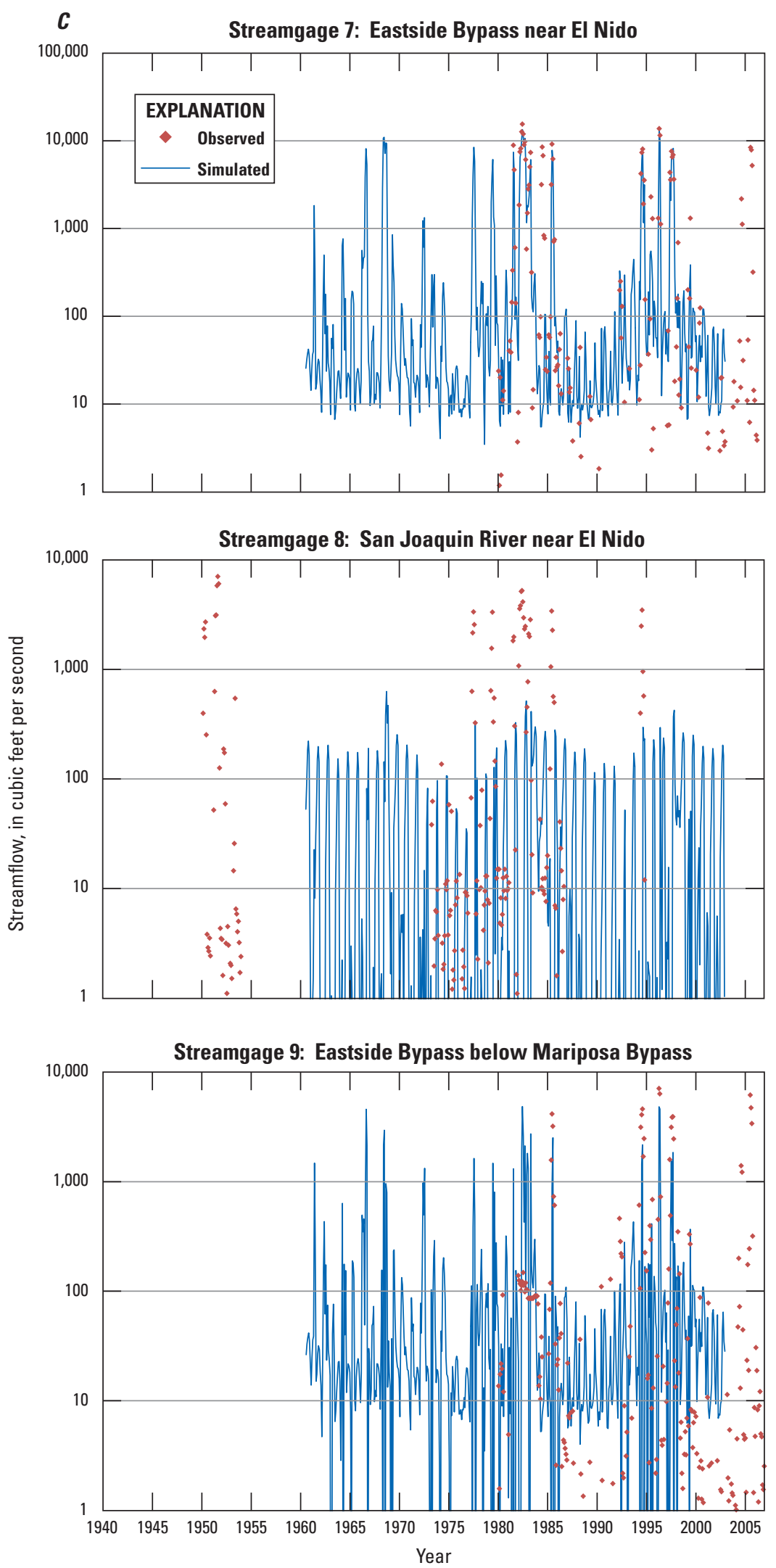

Figure C-2. - Continued 

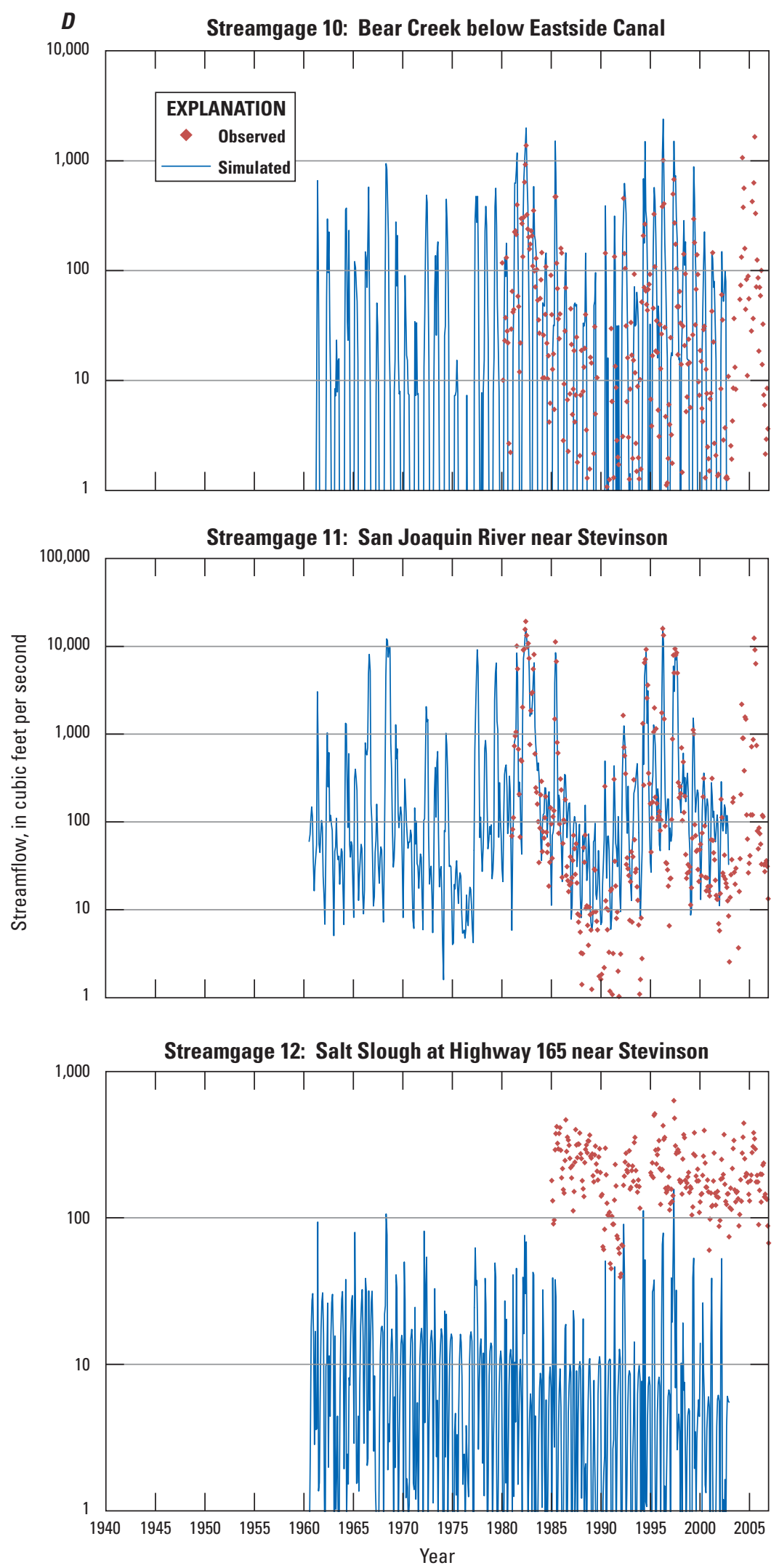

Figure C-2. - Continued 

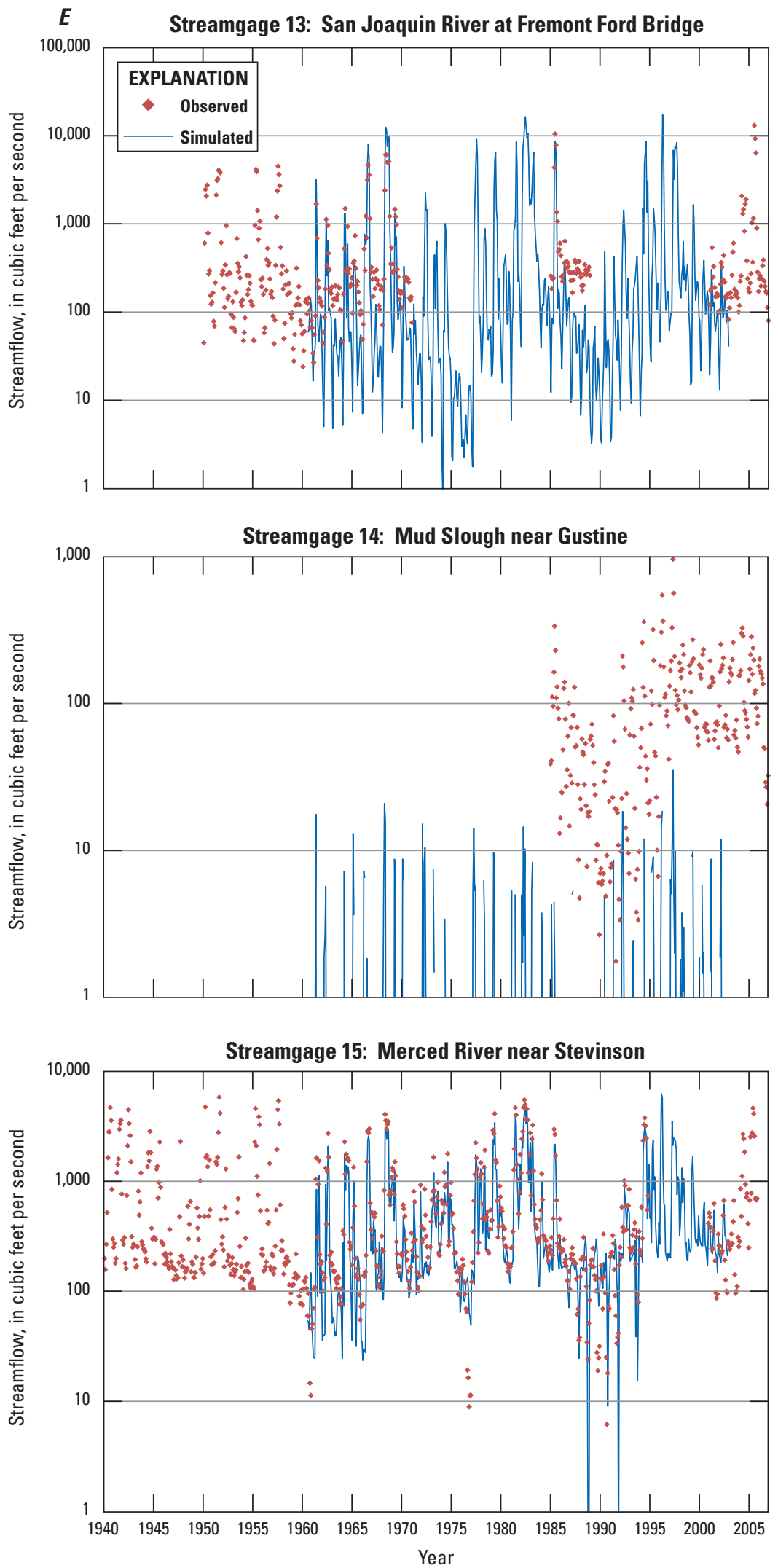

Figure C-2. - Continued 

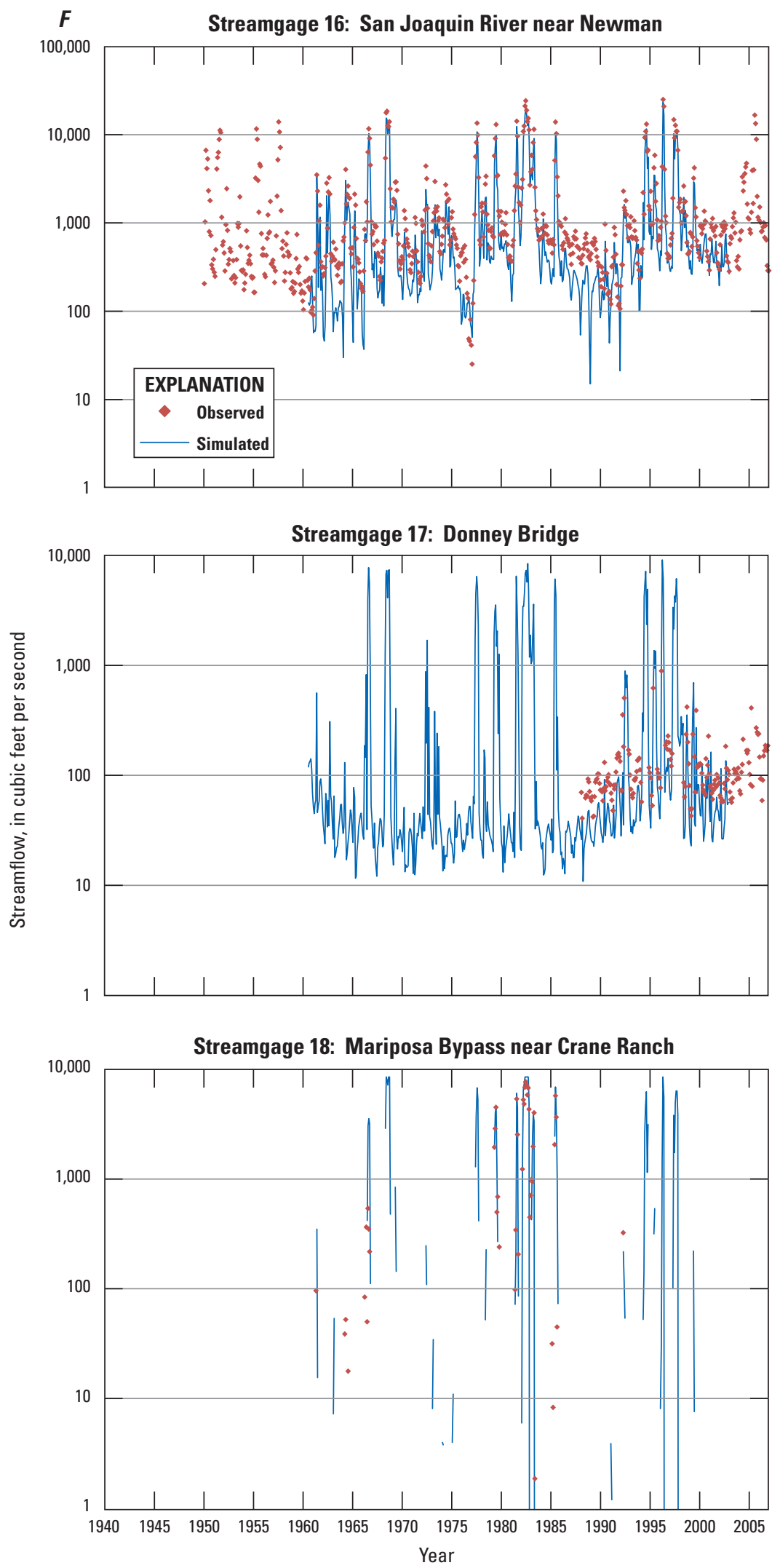

Figure C-2. - Continued 


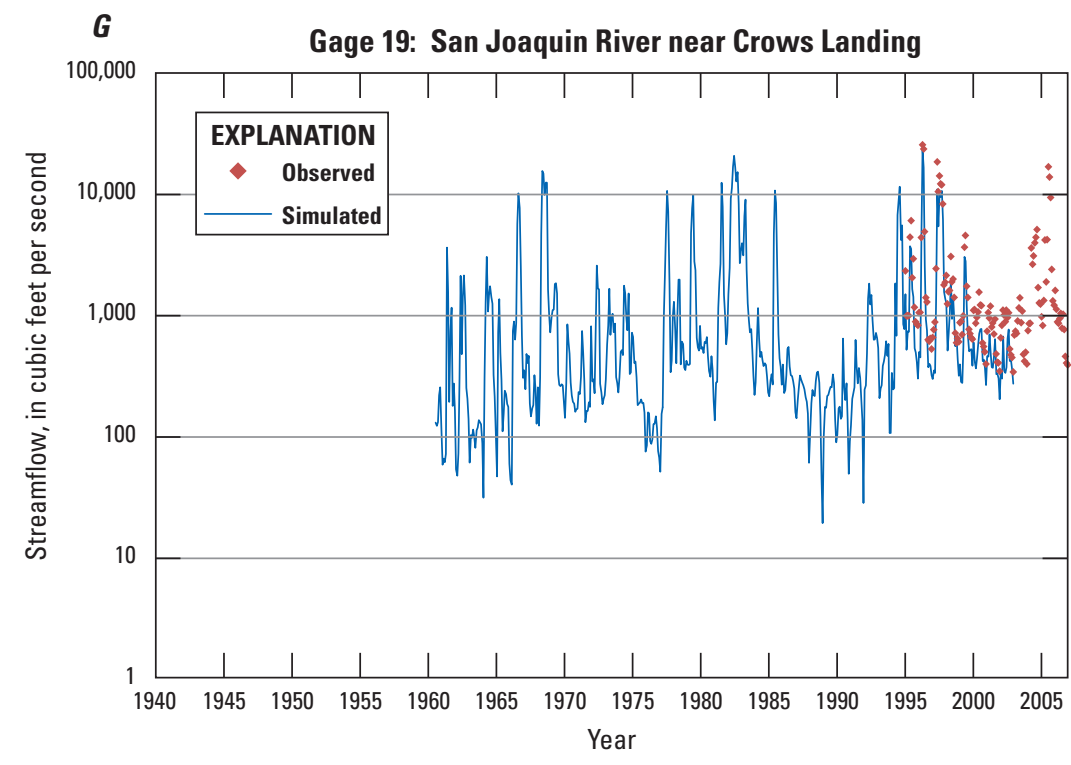

Figure C-2. - Continued 
Prepared by the Sacramento Publishing Service Center.

For more information concerning this report, contact:

Director

U.S. Geological Survey

California Water Science Center

$6000 \mathrm{~J}$ Street, Placer Hall

Sacramento, CA 95829

or visit our Web site at:

http://ca.water.usgs.gov 
